Andrzej Waśkiewicz

\title{
The Idea of Political Representation and Its Paradoxes
}




\section{The Idea of Political Representation and Its Paradoxes}

If we want to understand the vicissitudes of modern democracy then, argues the author, we need to analyse the ideas upon which representative government is based rather than compare contemporary conditions with the Greek ideal. These principal ideas have been presented clearly in past centuries, when the relation between democracy and representation was still a matter of political judgement. The old masters of political thinking clarified the functions of representation: legitimising power, creating sovereignty but also setting its limits, and pursuing the common good while still reflecting social diversity. Because institutions of representation are expected to fulfil a variety of functions, these institutions have in recent times come under attack for standing in the way of radical programs for democratising democracy. The author of this book reminds us that these functions are necessary in every political order, whether democratic or not. Instead of rejecting representation, political theorists should focus on making government more accountable.

\section{The Author}

Andrzej Waśkiewicz teaches history of social and political ideas at the Institute of Sociology and the Collegium Artes Liberales, University of Warsaw. He has authored numerous publications, including books on asocial philosophy of life, political theory and methods of its interpretation. 
The Idea of Political Representation and Its Paradoxes 


\section{STUDIES IN SOCIAL SCIENCES, PHILOSOPHY AND HISTORY OF IDEAS}

Edited by Bogusław Paź

VOLUME 24 
Andrzej Waśkiewicz

\section{The Idea of Political \\ Representation and Its Paradoxes}

Translated from Polish by Agnieszka Waśkiewicz and Marilyn Burton

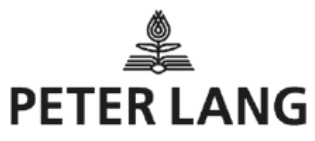




\section{Bibliographic Information published by the Deutsche Nationalbibliothek}

The Deutsche Nationalbibliothek lists this publication in the Deutsche Nationalbibliografie; detailed bibliographic data is available in the internet at http://dnb.d-nb.de.

\section{Library of Congress Cataloging-in-Publication Data}

A CIP catalog record for this book has been applied for at the Library of Congress.

The Publication is funded by Ministry of Science and Higher Education of the Republic of Poland as a part of the National Programme for the Development of the Humanities. This publication reflects the views only of the authors, and the

Ministry cannot be held responsible for any use which may be made of the information contained therein.

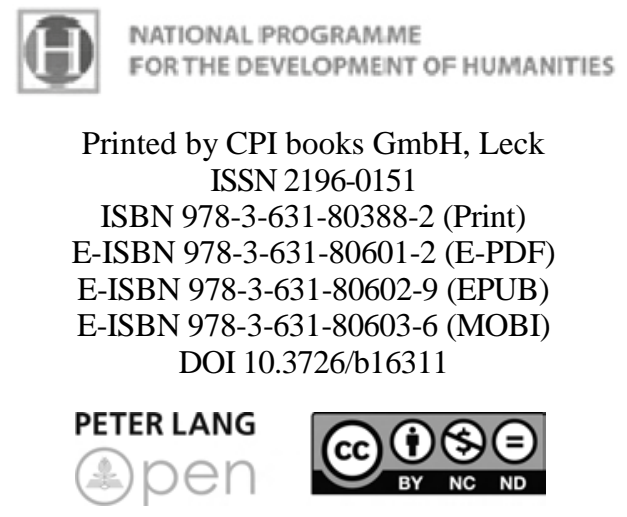

Open Access: This work is licensed under a Creative Commons Attribution Non Commercial No Derivatives 4.0 unported license. To view a copy of this license, visit https://creativecommons.org/licenses/by-nc-nd/4.0/

(C) Andrzej Waśkiewicz, 2020

Peter Lang - Berlin $\bullet$ Bern $\bullet$ Bruxelles $\bullet$ New York $\bullet$ Oxford $\bullet$ Warszawa $\bullet$ Wien This publication has been peer reviewed. www.peterlang.com 


\section{Contents}

Introduction to the English-language edition

\section{Representation as an impediment to democratisation} of democracy

Representation and the legitimisation of power .............................. 23

Aristotle's Legacy .............................................................................................. 23

Government in the service of the highest happiness:

De regimine by St. Thomas Aquinas

Power in the service of the unity of humankind:

Monarchy by Dante Alighieri

Power by the will of God and the people:

The Defender of the Peace by Marsilius of Padua

Top-down representation - bottom-up representation:

the two sources of legitimisation of secular power

Representation and sovereignty of power ........................................ 65

Sovereign, or unlimited, power

Sovereign power against representation:

Six Books of the Commonwealth by Jean Bodin

Sovereign power, thanks to representation:

Leviathan by Thomas Hobbes

Representation: sovereign rule over the author

A limitation of power, or the security of the ruled

A representative government of a political society:

Second Treatise of the Government by John Locke 
A power against a power - a party against a party:

The Spirit of the Laws by Montesquieu

A balance of interests and a natural elite:

The Federalist Papers

Representation and limited government:

instincts and institutions

\section{Representation and the common good ............................................... 151}

The common good and the procedures for defining it ............................... 151

Deliberation of the representatives of the nation:

'Speech to the Electors of Bristol on Being Elected' by Edmund Burke .... 155

A reformed Polish diet, i.e. an assembly of accountable delegates:

Considerations on the Government of Poland by Jean-Jacques

Rousseau

The rule of an intellectual elite in the representative body:

Considerations on Representative Government by John Stuart Mill

Representation of the common good:

representativeness in the representative body and a deliberating elite

\section{Representation and social diversity}

Social diversity as a problem of political institutions

Representation of representative interest:

James Mill's Essay on Government

The functional representation of associations:

George Douglas Howard Cole's The Social Theory

Representation of civil society:

Alexis de Tocqueville's Democracy in America

A diversified society and a diversity of representative government

\section{A contribution to the normative theory of representation}

Representation as a concept connecting the normative and descriptive theories of democracy 
A realistic theory of representative government and 'another' theory of democracy by Joseph Schumpeter

The paradoxes of the idea of representation, i.e. the classics' contribution to the contemporary normative theory of representative government

Bibliography 255

Index 267 



\section{Introduction to the English-language edition}

Even though I had made up my mind to write this book as early as the late 1990s, it was not published in Polish until 2012, as I interrupted writing it to focus on another project. I was motivated mainly by my discontent with the criticism addressed against the institution of representation by deliberative theorists, who are advocates of direct democracy procedures, as well as by supporters of representative government who wish to make institutions of representative democracy more representative through an inclusion of the voices of minorities. As I am a historian of social and political ideas, what irked me was the fact that the critics of representation attributed to the institution of representation a purely ancillary role in relation to democratic ideas. Slightly simplifying the matter, one could say that both critics and reformers expected representation to be a transmission belt ${ }^{1}$ for the will of the people, transferring it to the legislative forum. Such an approach ignores both the complexity of the very idea of representation and the multiplicity of the functions it may, according to the classics of political thought, perform in various political systems. My book was meant precisely to demonstrate that complexity and multiplicity in the historical aspect.

At that time, the classic work devoted to the idea of representation was The Concept of Representation by Hanna Pitkin ${ }^{2}$. Published in 1967, it was marked by logical positivism, which made the author seek in history the 'proper' meaning of the act of representation. Such an approach not only ignored the historical context of the texts under analysis, but also upheld the philosophical fiction of a universal glossary of political terms, methodologically false and completely obsolete in the era of proliferation of democratic ideas. Even if we assume that in the era of unchallenged democracy the only possible point of contention is which values are constitutive to it and what they mean in given social realities, to expect that those disputes will end in a consensus would be tantamount to a recognition that politics is deprived of its live ideological dimension and that the sphere of material interests remains its only domain. Disputes over the role of the institutions do also fall into the category of disputes over values. The old masters of political thought envisioned representation as playing roles quite

1 This concept is critically discussed by Nancy L. Schwartz, The Blue Guitar. Political Representation and Community (Chicago: The University of Chicago Press, 1988).

2 Hanna Pitkin, The Concept of Representation(Berkley-Los Angeles - London: University of California Press, 1967). 
different from those intended to perform in contemporary democracy, which itself is a hotly disputed subject. My book was meant to demonstrate that these disputes already have their own history, and this history reveals the paradoxes of the idea itself.

As I was finishing writing the Polish version back in 2010, I already knew that I was not the only one dissatisfied with the state of reflection on representation 10 years ago $^{3}$. The representative turn had been underway for a few years at that point, even though it was still in its early stages; characteristically, its first summing up invokes works still in press ${ }^{4}$. Those responsible for the representative turn included not only political scientists and theorists, but also normative democratic theorists, who were irritated by the oversophistication and detachment from empirical reality displayed by the deliberative turn authors. Without being uncritical apologists for representative democracy or questioning the need for institutional innovation, they demonstrated the complexity of the relation of representation, as well as, to a lesser degree, its normative aspect. However, they measured it against the democratic yardstick; to them, representation is the better the better it complies with democratic values. That is why my book, which shows the normative aspects of representation, whether it serves democracy or some other form of government (except for tyranny), allows the reader to understand and assess it in the context of its functions, both the formal, enshrined in constitutions, and those that are informal, but predicted by political theorists, and occasionally even by the authors of constitutions.

Making up my mind to have this book published in English several years after its Polish edition, I had to decide how to deal with the representative turn

3 I had earlier presented my idea of representation interpreted as a social relation in English in a form close to a Simmelian essay; cf. Andrzej Waśkiewicz, 'Representation as Social Relation,' Polish Sociological Review, No. 3 (2010).

4 Cf. Nadia Urbinati, Mark E. Warren, 'The Concept of Representation in Contemporary Political Theory,' Annual Review of Political Science, Vol. 2 (2008); cf. also an earlier article by Mark E. Warren, Dario Castiglione, 'The Transformation of Democratic Representation,' Democracy and Society, Vol. 2, No. 1 (2004). A work by David Runciman and Mónica Brito Vieira, Representation (Cambridge: Polity Press, 2008) sums up the first wave of the representative turn, and an Introduction to a book by Mónica Brito Vieira (ed.), Reclaiming Representation. Contemporary Advances in the Theory of Political Representation (New York and London: Routledge, 2017) provides a summary of the later literature. 
literature, published both prior to and after publication of my book in Polish. The reader familiar with the most recent works will easily note that apart from that normative aspect, many of the findings of political theorists and empiricists overlapped with the conclusions I had myself arrived at while reading the classics of political thought. As my arguments were already set in stone at the time of the Polish edition, I decided to comment on the works of contemporary authors only in the Introduction and in extensive footnotes concerning crucial questions. In the English edition, I decided to stick to this arrangement. Inadvertently, and therefore only to a limited degree, my book thus became a iunctim between the earlier and contemporary reflection on political representation.

There is one more way in which history is combined with the present in my book. Namely, it is a historical study with a moral. Even though I use historical texts as my sources, I draw from them a conclusion concerning present-day politics and political theory. It could not have been otherwise, as I was motivated by the wish to defend representation against theorists of permanent democratisation of democracy. In the conclusion of my work I indicate several points on which to build a theory of representative government, normative, but realistic at the same time. An element of realism in this theory is more than merely recognising that there is no democracy without representation ${ }^{5}$ : it consists in accepting Schumpeter's claim with Locke's proviso that in democracy political elites rule by the consent of the people and not the people with the assistance of their representatives. Accordingly, the normative aspect of that theory does not consist prima facie in the inclusiveness of the demos, but in the responsibility of the representatives for a diversified civitas.

Creating that kind of theory goes beyond the competences of a historian of ideas; however, history itself may only be a source of inspiration here. For whatever methodological purists may think, one reads great historical writings through the prism of present interests, but one should not look to them for definitive answers to contemporary questions. If I had known the works by the representative turn authors before writing this book, it would not have had that moral, but I am not sure if I would have had enough motivation to write it at all. Perhaps sometimes, it is really better not to know.

5 A point raised by David Plotke in the middle of the deliberative turn: 'Representation is Democracy, Constellations, No. 4 (1997). 



\section{Representation as an impediment to democratisation of democracy}

Contemporary normative political theory has not had much good to say about democracy as it is, or democracy in the shape it has assumed in the Western world, even though it no longer harbours any illusions that it exists outside it at all. Actually, what characterises the vast majority of the numerous models of democracy - states built by philosophers 'in mind' - is nothing other than attempts to democratise it. Accordingly, 'true' democracy is to be an assembly, associative, communicative, cosmopolitan, deliberative, direct, discursive, ecological, industrial, participative, pluralist, radical, referendums, reflexive, people's and, last but not least, virtual democracy (e-democracy) ${ }^{6}$.

This long list by no means testifies to a wealth of alternatives to the form of government described by its critics most delicately as an elitist or party democracy; the only thing it testifies to is the degree of discontent at its condition. Supposedly, the fundamental flaw, the original sin of that form of government is its having been dominated by an ideology that is at least ambivalent towards political commitment by citizens, or that 'the power of the people' has been institutionalised in it in a manner that completely distorts its essence, for which, incidentally, the same ideology is blamed. The first current of this criticism dates back to the time when democracy was still an idea leading the people to barricades, while the second has its source in disillusionment with democratic rule.

Differing as to the diagnosis of the current situation, the critics belonging to both currents are united in sending their readers back to ancient Greece, to the Athens of the Golden Age, so that they can find there the proper 'promise of politics', as recalled by Hannah Arendt and other 20th-century philosophers, looking for solutions to present-day maladies in antiquity. Allegedly, it is the modern liberal ideas and institutions of representation that have deprived the citizens of the experience of common action in the public forum, turning them into mere clients of government administration, jealously guarding their individual entitlements. Contemporary democracy, with all the pathologies it has been grappling with for over a hundred years, is confronted (in books as popular

6 Michael Saward, who drew up that list in 2002, offers the caveat that it is not complete; cf. Michael Saward, Democracy (Cambridge: Polity Press, 2003), p. 131-151. Ian Shapiro critically discusses the most important of these concepts; see Ian Shapiro, The State of Democratic Theory (Princeton: Princeton University Press, 2003). 
as Strong Democracy by Benjamin Barber, to mention only one of the most wellknown ones) with the ideal of the polis derived from Pericles' Funeral Oration.

Focusing on the problem of democratic deficit in institutions of power, advocates of their democratisation seem to fail to understand the complex character of the very idea of representation and the multiple functions it plays in its institutionalised form in the entire political system. For its role cannot be reduced to the exercise of power by the nominal sovereign through a small group of decision-makers. In reality, as will be discussed in this book, representation also legitimises their power, grants to representatives important rights vis-à-vis the represented, and at the same time prevents the abuse of those rights to the detriment of the ruled; it is also to serve in defining the common interest of the community as a whole, while at the same time reflecting the diversification of group interests.

The institution of representation could not perform any of these functions if it were completely subordinated to the idea of a representative body expressing the will of the people; however, these functions enmesh it in inevitable paradoxes which compromise it in the eyes of 'strong' democrats. Indeed, the latter are not far from the truth: the idea of representation is as democratic as it is antidemocratic and may serve virtually any form of government with the exception of a classical tyranny. Its institutionalisation in the democratic political system has concealed these paradoxes, however, while bringing the problems of the institution itself to the foreground - problems such as electoral law or the size of constituencies, which preoccupy political scientists nowadays, but which remain outside the horizon of philosophers' interests ${ }^{7}$.

That is why in order to comprehend the actual promise of politics in a contemporary democracy, it must not be derived from the Greek ideal of government by the people; rather, one should analyse the ideas upon which representative government is founded. For the fact that power is exercised by the category of professional politicians is more important to this form of government than the fact that it is formed by means of a universal election; such professional politicians may be defined as those living for politics and off politics, as Max Weber put it as early as the beginning of the last century. And even if in the long term each democracy is

7 This state of affairs actually continues to this day, even after the representative turn that will be discussed shortly. One of its authors, Andrew Sabl, recently summing up the discrepancies in approaches of political scientists and philosophers, notes that regrettably, to the former 'responsiveness of power' is sufficient to legitimise a democracy, while the latter do not want to learn the actual functioning of institutions from political scientists; cf. Andrew Sabl, 'The Two Cultures of Democratic Theory: Responsiveness, Democratic Quality, and the Empirical-Normative Divide', in: Reclaiming Representation, ed. Brito Vieira. 
indeed, according to Abraham Lincoln's formula, 'government of the people, by the people, for the people', then in the spirit of Thomas Hobbes one might say that people would have to live very long indeed in order to experience that. The abovementioned critics of representation, therefore, deserve some credit; they make all those who have failed to note it realise that democracy is not the power of the demos any more, and do so in an outspoken and spectacular way. One can only regret that their outrage at this state of affairs precedes an attempt to understand it.

A favourable interest in the idea and institutions of representation has appeared only in recent years. A representative turn has replaced the deliberative turn and brought a comprehensive, theoretically interesting interpretation, based on empirical data, of the relationship of representation in politics ${ }^{8}$, which may also benefit scholars studying the idea of representation as well as the history of that idea. From the perspective of the present work, of particular value are articles by Andrew Rehfeld, as well as by Jane Mansbridge and Michael Saward9. Naturally, the representative turn has not brought an unambiguous answer to the question of what representation is about ${ }^{10}$; quite the contrary, it demonstrated its complexity in the contemporary political system. In a ground-breaking article based on empirical research, Jane Mansbridge also distinguished, in addition to traditional or promissory representation, its three new types: 'anticipatory' (of the future constituency), 'gyroscopic' (the representative being one of the typical constituency members) and 'surrogate' (for the constituency absent in

8 To a certain extent, the representative turn has also taken into consideration symbolical and aesthetic representation: I am referring here in particular to political theorists from outside the English-language mainstream, such as Claude Lefort and Frank Ankersmit; see Sofia Näsström, 'Representative Democracy is Classless', in: Reclaiming Representation, ed. Brito Vieira.

9 Cf. Andrew Rehfeld, 'Towards a General Theory of Political Representation', The Journal of Politics, No. 68 (2006); Andrew Rehfeld, 'Representation Rethought: On Trustees, Delegates, and Gyroscopes in the Study of Political Representation and Democracy,' American Political Science Review, No. 2 (2009); Jane Mansbridge, 'Clarifying the Concept of Representation,' American Political Science Review, No. 3 (2011); Andrew Rehfeld, 'The Concepts of Representation,' American Political Science Review, No. 3 (2011); Michael Saward, 'The Representative Claim, Contemporary Political Theory, No. 5 (2006).

10 Andrew Rehfeld notes that 'there is a deficiency in contemporary scholarship that has failed to explain the concepts of representation in a manner that helps us describe, measure and evaluate the social and political world'; Andrew Rehfeld, 'What is Representation?, in: Reclaiming Representation, ed. Brito Vieira. This conclusion is a little surprising, considering that the author himself distinguishes in his text five possible types of a representative; why should each of them do the same thing? 
parliament $)^{11}$. None of these forms has appeared as a clear-cut idea, and in the absence of a clearly defined constituency, the accountability of representatives of that kind is a problematic question.

The representative turn cannot be said to have made an equally groundbreaking contribution to normative theory. Of greater importance to it were undoubtedly the works by authors such as Anne Philips, Iris Young or Will Kymlicka, who expected greater representativeness from representative democracy, i.e. a correction to make its institutions reflect the interests of women and ethnic minorities to a greater degree ${ }^{12}$. Among the representative turn authors, Nadia Urbinati follows the idea of John Stuart Mill and presents representation as advocacy ${ }^{13}$, which includes, among other things, deliberation with advocates of other interests. Suzane Dovi on her part argues ${ }^{14}$ that, contrary to what its critics claim, representation does not exclude citizens and does not turn an election into a plebiscite; quite the contrary, a good representative in a democracy, characterised by the three virtues she distinguishes (fair-mindedness, critical trust building and good gate-keeping), is meant to work towards increasing their political activism.

In the most exhaustive work belonging to this current, Andrew Sabl addresses the subject of politicians' obligations towards the people they represent, invoking Cicero's category of offices ${ }^{15}$ and illustrating his theoretical considerations with positive as well as negative examples from the most recent US history. Thus he draws his conclusions as much from the classic writings, from Aristotle to Tocqueville, as from analyses of biographies. The author argues that one cannot speak here of a single political ethic, but rather of 'governing pluralism', i.e. of a mutual complementation of three distinct ethoses: those of a senator, moral activist and community organiser ${ }^{16}$.

11 Cf. Jane Mansbridge, 'Rethinking Representation', American Political Science Review, No. 97 (2003).

12 The literature on the subject is abundant; a good summary is provided in, e.g., the new edition of Will Kymlicka's book Contemporary Political Philosophy (New York: Oxford University Press, 2002).

13 Cf. Nadia Urbinati, 'Representation as Advocacy: A Study of Democratic Deliberation, Political Theory, Vol. 28, No. 6 (Dec. 2000).

14 Suzanne Dovi, The Good Representative (New York: Wiley-Blackwell Publishing, 2007).

15 Andrew Sabl, Ruling Passions: Political Offices and Democratic Ethics (Princeton: Princeton University Press, 2002). Worth noting in this context is also a book by Andrew Rehfeld, The Concept of Constituency: Political Representation, Democratic Legitimacy and Institutional Design (Cambridge: Cambridge University Press, 2005).

16 Cf. Sabl, Ruling Passions, p. 300: 'Benjamin Constant described politics in terms of a division of labor between citizens and representatives: the latter engage in politics so 
Characteristically, what does not appear in those works any more is the tension between democracy and representation which had animated the deliberative turn - not as a typical conflict of values in any case. It is not immediately obvious, for the very idea of representation has never had an ideal form, nor has it ever been a political ideal: it has not belonged to those mottoes one writes on one's banners. This is not to say, naturally, that it has never been demanded just as liberty, equality and fraternity were. Mediaeval subjects demanded the right to representation before the monarch, who called himself the representative of God on Earth. Estate representation was meant ultimately to guarantee them a whole range of liberties, limiting arbitrary royal power. However, at the outset of the modern era, the ruled would no longer put forward such a demand before a representative government, even if it was not fully democratic, as was the case following the revolutions in England, France and America. The petty bourgeoisie in France, demanding a lowering of the property qualification to vote in the mid-19th century, were already demanding representation within the government, rather than before it. While what is at stake in both cases is participation in the exercise of power, it is in the name of different principles, and this difference is by no means a minor one.

The complex relations between democracy and representation remained latent because, beginning form the mid-19th century, representative democracy, so its advocates believed, was expected to combine democratic values with normatively neutral institutions. This is what is expressed by the transmission belt idea. Many if not most of its contemporary critics from the wide democratisation of democracy current have rejected this assumption, arguing that the more representative it is, the less democratic it must necessarily become. No matter how much truth there is in that statement, there is no doubt that the logic of democracy and the logic of representation are not fully compatible, of which fact the first theorists and architects of a representative democracy were already aware. Representation need not necessarily promote democratisation; indeed, it may stop it or at least slow it down. It is therefore difficult for strong democrats of the 20th and 21st centuries to praise representation; the most they can do is reconcile themselves to it as a necessary evil.

That is why, in order to understand the complex character of representative government, one needs to draw on the classic works of political thought whose authors had not yet subordinated the idea of representation to the logic

that the former need not spend time doing so. One could defend the offices described in this book in the same way. On such an account, the organizer would talk to ordinary people face-to-face so that senators could stay more distant; activists would stress moral principles so that organizers could forget about them; senators would discuss and trade off interests among one another so that activists could be blind to interest, and so on'. 
of democracy, as well as those to whom the relationship between government by the people and representation of the people was still a problem of principles and values, rather than merely one of the technical solutions. Thus, the classic work by Hannah Pitkin The Concept of Representation still remains an irreplaceable guide to the subject ${ }^{17}$; it is particularly relevant to this book as it invokes works by the above-mentioned authors of the pre-democratic era.

In a manner proper to analytical philosophy, drawing on Wittgenstein's late works, Pitkin distinguishes four types of representation: 1. Formal representation, the essence of which is the status of a representative in its two aspects: the authorisation he was granted by the represented to act on their behalf, and his accountability to them; 2. Symbolic representation, referring to the meaning carried by that act; 3 . Descriptive representation, stressing the representativeness of the person of the representative to the represented; and 4. Substantive representation, consisting in the representative's acting on behalf of the represented. Representation is therefore a complex phenomenon; the paradoxical formula (to represent, i.e. making re-present ${ }^{18}$ ) is too broad not to attach to it various, contradictory senses. Pitkin herself, as evident from the term quoted above, favours the fourth sense, with the reservation, however, that all the others contribute something important to the understanding of that relationship as well ${ }^{19}$.

In the literature a dispute is under way, naturally, as to whether representation in that sense is an original idea of modernity, or rather a mediaeval or maybe even Roman idea, which only undergoes a fundamental metamorphosis in the thought of 17th-century authors. The subject of this book does not force me to take an unequivocal stance on the issue. For its purposes, I assume that even though the idea of representation as the principle constituting political power was born in the late Middle Ages, in its present-day form, i.e. in the functions it performs nowadays, it is indeed a modern idea. In the late mediaeval thought, it emerges only in order to

17 While appreciating Pitkin's analyses I completely agree with the now widespread opinion that her conception is of no use to a political scientist: it is too static, and does not cover informal relations, their scope and dynamics, and in particular the fact that representation is in fact a tripartite relation, as argued by Rehfled, Towards, p. 6-11, and Saward, Representative, p. 299-301; additionally, the problem of representation may not be reduced to authorisation, as claimed by the authors belonging to the so-called constructivist turn; see Saward, Representative, p. 312-314.

18 David Runciman discusses this paradox extensively; cf. David Runciman, 'The Paradox of Political Representation, Journal of Political Philosophy, No. 15 (2007).

19 Writing on representation as a social and not only political relation, I myself classify it according to its subject: the presence, will or interest of the represented; cf. Waśkiewicz, Representation, p. 310-311. 
serve to legitimise secular power; it is only authors of the modern era who will find other applications for it. In the modern era, it will also assume a different, subjective, sense, enclosing it in the universe of human relations, while in the Middle Ages, it still connects the human and supernatural worlds, in which collective actors and metaphysical beings are no less real than individual and physical ones ${ }^{20}$.

It is for that reason that in mediaeval thought the first out of the five paradoxes of representation discussed in this book manifests itself more clearly in the context of its function of legitimisation of power. Arguments in support of it are then as much philosophical as theological; a discussion of the latter would, however, go considerably beyond the scope of the present work, and it is not necessary for presenting the paradox in question ${ }^{21}$. The other four paradoxes are already illustrated by mainstream modern political thought; the axiom of the representative character of government is actually one of the trademarks of that current. The 17th-, 18thand 19th-century philosophers regarded today as the masters of political thinking take it for granted that power comes from the ruled, but even as the Americans, the French and the Poles enshrined that principle in their constitutions, most Europeans still regarded power as God-given. However, it is not paradoxes of this kind in political thought in the context of historical developments that are the subject of this book, but only those that are inherent in the very idea of representation.

Chapter One presents a paradox resulting from the function of legitimising secular power. Marsilius of Padua derives it, like St. Thomas Aquinas and Dante Alighieri, from the premises of Aristotle's philosophy, but he manipulates them in such a way as to make the emperor a representative of the entirety of humankind, and the council a representation of the Church as a whole. The divine origins of all power do not allow him to develop this doctrine; the clash of the two types of representation - from the bottom up, i.e. of the people before God, and from the top down, i.e. of God before the people - reveals, however, that, paradoxically, it is the representative who needs principals in order to legitimise his power over them or over those before whom he represents them.

20 For more on the subject, with an emphasis on the continuity of the idea rather than on its interruption/discontinuation, see Harvey C. Mansfield, 'Modern and Medieval Representation, in: Nomos X: Representation, ed. James R. Pennock, John W. Chapman (New York: Artherton, 1968).

21 I refer the interested reader to the literature on conciliarism, as well as to works by Eric Voegelin cited here occasionally; see in particular Eric Voegelin, The People of God. Materialien zu Eric Voegelins 'History of Ideas' (München: Ludwig-MaximilianUniversität, 1941), III. 
Chapter Two illustrates the paradox of that idea in the context of sovereignty of political power. The concepts of sovereignty in the theories of two authors from the 16th and 17th centuries, Jean Bodin and Thomas Hobbes, are so different from each other that only the author of Leviathan, invoking the idea of representation, can give power a consistently absolute character. Bodin does not want to place the sovereign above the law of nature; Hobbes, by contrast, does not hesitate to deprive the represented of any kind of control over their representative. By virtue of representation, the author of the act, paradoxically, loses all individual power to the sovereign, gaining instead a promise of protection of individual lives.

Chapter Three is devoted to the paradox of representation that is meant to curb the absolute power instituted by Hobbes. The idea of limited representative government was created by John Locke, while Montesquieu enriched it with the principle of mutual checks between the legislative and the executive. In doing so, both made assumptions concerning human nature that must have nevertheless seemed too risky to the architects of the American republic who took advantage of their inventions. Ultimately, therefore, it is the latter who institutionalise the idea of representation in such a manner that, paradoxically, the safety of the ruled turns out to be a by-product, as it were, of relations between the representatives and the represented.

Chapter Four reveals the paradox of representation as an institution subordinated to two procedures of defining the common good: deliberation and aggregation. Selected works by Edmund Burke, Jean-Jacques Rousseau and in particular John Stuart Mill demonstrate how different are the forms of government that the idea of representation may lead to depending on the procedure to which it is subordinated. In accordance with that procedure, whether deliberation or aggregation, members of the representative body not only gain a certain degree of autonomy from their principals, but also, paradoxically, they cannot follow one procedure without taking account of the other, meaning that they cannot apply them consistently.

Chapter Five focuses on the paradox of the idea of representation following from the fact that it is meant to reflect the diversity of the general public in a representative body. The conceptions of John Mill (the father) and George Douglas Howard Cole may be regarded as two extreme solutions to the question of representativeness of representative institutions, whereas Alexis de Tocqueville believes that American democracy solves the problem admirably. This solution occurs, however, only in a political order that includes civil society institutions, themselves performing representative functions; yet, paradoxically, the efficiency of those institutions reduces the representativeness of the formal institutions of representation. 
Accordingly, this book presents in the successive chapters precisely what its title announces: five paradoxes inherent in the idea of political representation, as seen in the contexts of various other ideas with which it is enmeshed. It is not a history of the idea of representation, as might be suggested by the order of the cited sources. Nor is it an exhaustive analysis of it in works by particular authors; it discusses them only in so far as they fit into the context of the paradox under discussion, almost completely ignoring their historical contexts. The structure of the work is therefore completely arbitrary and subordinated to one purpose only, namely to presenting the complexity of the idea under discussion, which is illustrated more clearly by historical sources than by contemporary discourse.

In the conclusion of my book, I list the paradoxes discussed in particular chapters and formulate conclusions that should be drawn from them not only by the normative, but also by the realistic theory of representative democracy. Contrary to the advocates of democratisation of democracy, I assume that it should not set up ideals that the existing institutions do not allow to be achieved. If, on the other hand, democracy proposes an institutional order consistent with these ideals, it should demonstrate how the projected institutions will perform those functions that are currently performed by the institution of representation. For even if the institution of representation demarcates the limits of democratisation, it must not be regarded solely as a necessary lesser evil, without which an extensive state would not be a democracy at all ${ }^{22}$. Whether it serves democracy or not, it performs functions inevitable in any polity in which the rulers are accountable to the ruled in one way or another ${ }^{23}$.

22 This is an idea that does not fail to appear in the most recent literature I mentioned earlier; cf. Urbinati, Warren, The Concept, p. 402.

23 After I had already completed this book, I read Pierre Rosanvallon's CounterDemocracy: Politics in an Age of Distrust (Cambridge: Cambridge University Press, 2008) and found in it a number of views I should have commented on here. The most important one is a thesis that counter-power is inherent in the democratic project, which could not, however, have been institutionalised as a constituent element of that form of government (p. 299). Actually, counter-democracy could not have become part of representative democracy because - a point I completely agree on with the author - it is not merely a different name for direct democracy inherent in a system that would tolerate representation. On the other hand, numerous institutions of counter-democracy have a direct democracy character. 



\section{Representation and the legitimisation of power}

\section{Aristotle's Legacy}

While employing Mozart's Don Giovanni to demonstrate how sensuality manifests in music, Søren Kierkegaard made a passing observation with enduring consequences. The reason the ancient Greeks had never discovered the notion of representation, he argued, was that their religion prevented them. Kierkegaard's premise in The Immediate Erotic Stages as to how representation becomes obvious rests on the assumption that all of its 'power' is vested exclusively in a single individual ${ }^{24}$. The many experiences that force only to the extent that they participate 'in the particular movements of that one' and only in so far as they contemplate that person's power. For Kierkegaard, the crucial barrier in ancient Greek religious beliefs impeding this insight was that Greek gods did not possess the force each god represented. Rather, all of the material world's 'objects' not only traced their powers back to 'their' god, but also extracted these powers. The god himself was therefore weak and almost powerless to influence what his objects did.

By contrast, the idea of representation is omnipresent in Medieval Christian culture, even if only vaguely understood. At this point, it would be well to let Kierkegaard make the distinction himself:

[T] he totality is represented in a particular individual, yet in such a way that it is only a particular aspect that is defined as the totality and that is now manifest in a particular individual, who is therefore both more than and less than an individual. Then alongside this individual stands another individual, who just as totally represents another aspect of the content of life - for example, the knight and the scholastic, the clergyman and the layman. Here the great dialectic of life is continually exemplified in representative individuals, who are ordinarily paired opposite to each other. Life is continually approached sub una specie [under one form], and there is no inkling of the great dialectical unity that life possesses in unity sub utraque specie [under both forms] ${ }^{25}$.

24 Søren Kierkegaard, 'The Immediate Erotic Stages' in: Either/Or, Part I, Edited and Translated with Introduction and Notes by Howard V. Hong and Edna H. Hong (Princeton, New Jersey: Princeton University Press, 1987), p. 63-64. I owe it to Szymon Wróbel that I consulted Kierkegaard's work; it was he who deciphered Carl Schmitt's laconic reference (in his Roman Catholicism and Political Form) to a Protestant theologian writing earlier on representation in a similar vein.

25 Kierkegaard, 'The Immediate', p. 87. 
Thus, what is characteristic of the mediaeval mind is allegorical thinking; the political philosophy of that era is also governed by this style of thinking, even though it is the thought of Aristotle, referred to simply as the Philosopher in scholasticism, i.e. the decisive influence on it. Interpreted suo bono, Aristotelian philosophy is the starting point for the works discussed in the present chapter: $D e$ regimine principum by St. Thomas Aquinas, Monarchy by Dante Alighieri and The Defender of the Peace by Marsilius of Padua ${ }^{26}$, which examines the relationship between the idea of representation and the legitimisation of secular power. While there is no such relationship in Aristotle's thought, his distinction between 'true' and 'perverted' governments has some relevance to the subject of representation.

Obviously, Aristotle does not claim that power derives from God, but neither does he claim that it derives from the people. Whence does it come, then? One cannot infer any answer to that question from Politics, because its author is not concerned with power in an abstract sense, but rather with its specific forms, i.e. forms of government. For example, Aristotle's view on the changes that governments undergo is characteristic here. As a change of the form of government means the emergence of a new state, it is even disputable whether the new state should take over the obligations incurred by the former government vis-à-vis other states.

For, since the state is a partnership, and is a partnership of citizens in a constitution, when the form of the government changes, and becomes different, then it may be supposed that the state is no longer the same, just as a tragic differs from a comic chorus, although the members of both may be identical ${ }^{27}$.

Therefore, it is of no importance that the new state is inhabited by the same people, considering that after the change of the form of government it is now inhabited by other citizens. The state is a community of citizens, not an institution existing independently of them, meaning that they do not so much constitute the government as they appoint the rulers from among themselves. The

26 St. Thomas Aquinas, 'The treatise "De regimine principum” or "De regno", in: Political Writings, ed. R. W. Dyson; Dante Alighieri, Monarchy, trans. Prue Shaw (CambridgeNew York-Melbourne: Cambridge University Press, 1996); Marsilius of Padua, The Defender of the Peace, trans. Annabel Brett (New York: Cambridge University Press, 2005).

27 Aristotle, 'Politics', 1276b (Book III, \$ 3), in: The Complete Works of Aristotle, The Revised Oxford Translation, ed. Jonathan Barnes (Princeton, N.J.: Princeton University Press, 1991), II, p. 50. 
relationship between the citizens is that of equality, isonomia, rather than that of inferiority-superiority, characteristic of the relationship of power; in an ideal state, so Aristotle argues, citizens are friends to one another. That is why, in his general considerations on politics, he pays a great deal of attention to the idea of citizenship, rather than to the idea of power, and in those books of his Politics that have the most empirical character - the ones that we would classify today as belonging to political science - he discusses exclusively its specific institutions ${ }^{28}$.

What touches upon the problem of representation is the Aristotelian classification of the forms of government, for the objective that a given government sets itself determines the relationship between the rulers and the ruled, which may be defined in terms of representation, even if that institution was unknown to the Greek philosopher. In true forms of government, the government - no matter whether it is exercised by one, or a few, or many - seeks the well-being of the state as a whole, i.e. in a way represents the general interest, while in perverted forms of government, seeking its own good, it only represents the interest of that part of the polis which dominates in the polity. In this sense, and only in this sense, one may say that there exists - or does not exist - a relationship of representation between the ruling part and the entirety of the ruled.

Aristotle himself does not need a description in terms of representation in order to distinguish between a government discharging its function properly and a perverted government. Modern authors, as we will discuss in Chapter 4, need representation as a specific procedure for determining what belongs to the common good of all the citizens. Meanwhile, according to Aristotle, the common good has some substantial contents, something that the citizens merely discover in the course of the debate in the agora. An individual clearly surpassing all others in virtue - one to whom Aristotle would be ready to give full power over the polis, if only he could find such a person - would not need to debate with anyone on the subject.

Thus, the author of Politics does not elaborate on the subject of common good in the context of government agencies. As a student of the various forms of government, he does not stress the distinction between the true and perverted forms of government in the central books of his treatise; he does, however, analyse

28 That is why, Heinz Eulau claims that the Greeks' political theory had to fail them, because, showing no interest in the techne of government, it did not reveal the actual mechanisms of exercising power; without a proper theory of politics, the Greeks could not create the institution of representation; cf. Heinz Eulau, 'Changing Views of Representation', in: Contemporary Political Science: Towards Empirical Theory, ed. Ithiel de Sola Pool (New York: McGraw Hill, 1967), p. 62-64. 
the benefits that they bring to various social groups. One may say that Aristotle the philosopher does not see the state as an institution representing the citizens, while Aristotle the political scientist treats the government as a representation of group interests. Characteristically, he does not even mention any conflicts between them; political power creates a social order because it takes the diversity of those interests into consideration; it is for this reason that political science is described as the 'master art' at the beginning of the Nicomachean Ethics.

Classic tyranny is a meaningful exception here. More precisely, it is this type of tyranny which, according to Aristotle, 'deserves this name the most'; for even though it is a kind of one-man rule, it is at the same time the absolute opposite of kingship.

This tyranny is just that arbitrary power of an individual which is responsible to no one, and governs all alike, whether equals or betters, with a view to its own advantage, not to that of its subjects, and therefore against their will. No freeman willingly endures such a government ${ }^{29}$.

A tyrannical government does not represent anyone; it is not, therefore, in the least representative or legitimate. A tyrant does not rule with the consent of the ruled and thus is not accountable to them. Moreover, not seeking that consent, he is not even an impostor, for an impostor would like to legalise his power. Nor does a tyrant's rule represent any political value, as it does not bring any advantages to the ruled, not even any basic order, since obedience towards the ruler is based on fear alone. It is no accident, however, that Aristotle fails to criticise tyranny for its being established by way of a coup d'état. It is not the circumstances of the rise to power, but only the manner in which power is exercised that makes it illegitimate. Actually, the author of Politics does not consider any form of government to be perverted solely because it was established without the consent of the ruled.

Consequently, the problem of the origins of power - the rulers' legitimisation to wield power or the lack thereof - is of even less importance to Aristotle in his considerations on the best form of government. The aim of the state is to ensure a happy life for its citizens; that is why, it will be assessed exclusively according to this yardstick: how far it is capable of discharging that task. A happy life for citizens is a life of public activity, a political life in a broad sense of the term. They do not think of power in terms of goods that they may acquire thanks to it, as it is the wielding of power that is the highest good that the state may give them. Why, therefore, would they want to deprive themselves of it? Even if the true forms

29 Aristotle, Politics, 1295a, Book IV, §9, p. 86-87. 
of government differ from the perverted ones in that only part - one, a few, or many - rule/s for the well-being of the whole, this part never rules in the name of and by the will of that whole.

However, the problem of legality of power in the context of its origins arose in antiquity, even though, interestingly, it was not Christian thought (which assumed as a matter of principle that all power, even that persecuting the disciples of Christ, came from God) that was the first to address it. It was instead imperial power itself, which was seeking new legitimisation after having abandoned, at the time of the Dominate, the appearance of republicanism which had been a façade of the Principate ever since Augustus' time. Frank Kolb's study devoted to the ideal of a ruler in late antiquity, in terms of his ideology and self-presentation, shows how the Roman emperors step by step attached sacred attributes to their power. This process began in Diocletian's rule, following the rule of the military emperors, when the emperor's authority was considerably undermined. The tetrarchy system created by Diocletian and presented as a divine house (domus divina) of the sons of Jupiter and Hercules was intended to offer an ideological alternative to the Christian Son of God ${ }^{30}$.

Incidentally, some Christian thinkers of antiquity, too, acknowledging the divine origin of power, carried their ideas to the point of idolatry, naturally only after the Christianisation of the empire. This first occurred in the caesaropapism doctrine created by Eusebius of Caesarea, in the rule of Constantine, the first emperor to get baptised. The two states that St. Augustine writes about a century later were one and the same in Eusebius's idea.

That Eusebius's and Constantine's ideas of a Christian Empire were in agreement is evidenced by the fact that both attributed to the ruler an identical leadership role visà-vis the Church. The difference lay in the fact that Eusebius spoke here about a bishop (=overseer) of all (the Church), while Constantine considered himself to be the overseer of all his subjects. Thus, Constantine believed in his own Divine vocation. He put the work of salvation carried out by himself side by side with the work of Christ. He called himself 'a man of God who had long fathomed the essence of everything' ${ }^{31}$.

Even so, Constantine understood that Christians would not accept the divinity of their earthly ruler after his death, given that the idea already sparked controversy in his lifetime. He was eventually buried as an 'ordinary Christian emperor', and none of his successors went to that extreme in the sacralisation of

30 Cf. Frank Kolb, Herrscherideologie in der Spätantike (Berlin: Akademie Verlag, 2001), p. 35.

31 Kolb, Herrscherideologie, p. 71. 
his person/office. Despite the Byzantine formula of 'power by the grace of God', imperial power at that time preserved both the secular proclamation act and the secular terminology; only ideology presented the emperor as a sanctified individual close to $\mathrm{God}^{32}$. The theocratic aspect of secular power was to resurface several centuries later in Western political thought, but in a different context ${ }^{33}$.

The two secular political ideas of antiquity, that of the polis and that of the empire, which were inherited by mediaeval Europe, could not be used, claims Pierre Manent, to solve what he describes as a 'theologico-political problem.' Thus, feudal Europe became dominated by monarchy, a form of organisation of social life in-between an empire and a city-state. Monarchy did not pretend to universalism - which the Church and the empire had reserved for themselves and at the same time required much less involvement in political life as compared to the city-state, involvement that had been regarded with suspicion from its very beginning by the Church, which rightly believed it to draw attention away from eternal things ${ }^{34}$.

Monarchy, Manent further argues, could therefore provide an institutional solution to the problem of the place of the Church in a respublica christiana, even though this conflict continued throughout its history and intensified at the time of the Reformation. For monarchy was capable of containing it within certain limits, and was also able to adjust by itself to new historical circumstances and maintain its institutional continuity right up until the liberal state solved that problem (if problems of that kind can be resolved at all) by embracing the principle of religious neutrality. Following Manent's argument, one may say that monarchy was capable of this because both ideas of representation had been put into practice in its institutions: that of top-down representation, in which the ruler represents the One by whose grace he rules before his subjects, and that of bottom-up representation, in which the ruled put forward their representation before the ruler, thus limiting his arbitrary rule (the political theory of representative government was to follow a different route; however, this subject will be discussed in the following chapters).

32 Kolb, Herrscherideologie, p. 107.

33 Ernst Kantorowicz discusses the subject exhaustively in his classic study The King's Two Bodies, in particular in Chapter IV; see Ernst H. Kantorowicz, The King's Two Bodies. A Study in Mediaeval Political Theology (Princeton, New Jersey: Princeton University Press, 1997).

34 Cf. Pierre Manent, An Intellectual History of Liberalism, transl. Rebecca Balinski, Jerrold E. Seigel (Princeton: Princeton University Press, 1996), Chapter 1. 
These two doctrines were hatched in disputes between the spiritual papal rule and the secular imperial rule, and in the ecclesiastical dispute between the decretalists and the conciliarists, who argued as to whether it was papal decrees that were superior to the resolutions of the council or the other way round. While the treatises by Dante Alighieri and Marsilius of Padua discussed below are directly involved in these disputes ${ }^{35}$, the 'mirror for princes' written for the king of Cyprus by St. Thomas Aquinas, even though predating those debates, seeks to balance out the arguments that were later used by both sides of the firstmentioned dispute.

\section{Government in the service of the highest happiness: De regimine by St. Thomas Aquinas}

While in this speculum principis, a work typical of the Middle Ages, St. Thomas does write about the origins of power, he nevertheless pays much more attention to its functions. The goal of the human community, he repeats after Aristotle, is a virtuous life. If people lived together merely to survive, their community would also include both slaves and animals, and if their only goal were to acquire wealth, merchants alone would create communities for themselves. But in fact, all people, the rich and the poor, the learned and the simple, the sick and the healthy, live within one community and support one another. The community that St. Thomas speaks about is therefore broader and less elite than Aristotle's community of citizens. Not only does it help its members to excel in virtue, but first of all to meet their most basic needs; that is why, its government, too, must discharge more elementary functions in it. People, with their nature tainted by original sin, are not capable of a lasting peaceful coexistence without its mediation. St. Thomas argues:

For if many men were to live together with each providing only what is convenient for himself, the community would break up into its various parts unless one of them had responsibility for the good of the community as a whole ${ }^{36}$.

35 The conciliarists cited Marsilius' arguments, without quoting him, however, because his book was condemned and burnt at the University of Paris in 1324, and he himself was excommunicated; cf. Peter E. Sigmund Jr., 'The Influence of Marsilius of Padua on 15th-Century Conciliarism, Journal of the History of Ideas, Vol. 23, No. 3 (1962), p. 392-396.

36 St. Thomas Aquinas, De regimine, Book I, Chapter I, p. 51. 
A government must manage the community like reason manages the body. In order to coordinate the actions of the community, government is necessary even in a community of perfectly enlightened and virtuous people ${ }^{37}$. And because the need for community life lies in human nature itself, ultimately the need for government derives from human nature.

Politics, being the exclusive domain of power, is therefore to St. Thomas nothing other than 'management activity'. The ruler acts politically when he directs his community towards certain goods that are necessary for its well-being. The community needs the politics, thus defined only conditionally, in so far as it needs the goods that it gains, thanks to it. In the Aristotelian scheme, the citizen needed power in order to acquire moral capacities by exercising it: not only to speak to his equals, but also to listen to them; all the Christian subjects may do in the presence of the ruler, like a barbarian in the eyes of the Greeks, is practise the virtue of obedience ${ }^{38}$. In the economy of salvation, government is that institution which sets up conditions conducive to practising a life deserving of an eternal reward. For Christians, it is the revealed religion itself that fills up the space for improving oneself that the agora represented for the Greeks, because the evangelical virtues may, without exception, be practised within a private space. Hence the citizens, or subjects, more precisely, are freed from the obligation to conduct a public life. Thanks to this, in St. Thomas' basically Aristotelian scheme of political thought, a place appears for exercising power in the interest of the ruled, but without their participation, something precluded by the normative theory of the author of Politics (though allowed by his theory of forms of government).

The point is that if in St. Augustine's empire salvation still remained an individual matter, even if officially the Roman state was already Christian (heresy was considered a breach of public order), then in the medieval respublica christiana St. Thomas considers it, rather, to be a common good, or at least one acquired within a community. While an early Christian pilgrim travelled to his heavenly abode within an invisible spiritual community, a Christian living in the following millennium proceeds there together with his earthly homeland. St. Thomas argues:

37 Yves Simon writes thus on any lay authority, referring directly to St. Thomas; cf. Yves R. Simon, A General Theory of Authority (Notre Dame, Indiana: University of Notre Dame Press, 1980), in particular p. 50-51.

38 Simon emphasises, however, that, thanks to government, we may also satisfy our social needs; consequently, the necessity of government does not result exclusively from the weakness of human nature; cf. Simon, A General Theory, p. 26 and 49. 
But because the man who lives according to virtue is also directed towards a further end, which, as we have already said above, consists in the enjoyment of the Divine, the end of the whole community of mankind must therefore be the same as it is for one man. The final end of a multitude united in society, therefore, will not be to live according to virtue, but through virtuous living to attain to the enjoyment of the Divine ${ }^{39}$.

Consequently, to a certain extent, the ruler is ultimately responsible for the salvation of his subjects; naturally, he cannot be blamed for the eternal damnation of his subjects, but he may be reprimanded unless he does his best to save them from that.

In assessing the forms of government, St. Thomas is guided precisely by this criterion of potential efficiency in achieving the goal of a moral nature. Drawing upon the Aristotelian typology, he speaks decisively for the rule by one and against the rule by many. A rule by one follows from the very nature of social life; St. Thomas compares the tasks discharged in it by the government to the job of a helmsman. In Chapter IV of the treatise, despite its title announcing that it will demonstrate 'that just as the rule of one is the best when it is just, so its opposite is the worst; and this is proved by many reasons and arguments', he actually invokes only one argument in favour of monarchic rule: the person of the king unites all the power; all the other arguments are formulated against the rule of a tyrant. In Chapter VI he argues, in conformity with its title, 'that tyrannical government more often arises from the rule of many than from that of one; and so government by one is better'; he vindicates the monarchy as the form of government which, even if it turns into tyranny - which occurs more rarely than in the case of the rule of many, incidentally - causes less evil than 'when the government of a number of the best men becomes corrupt $\mathrm{t}^{30}$.

Thus, St. Thomas defends monarchy as the best form of government as much as he defends it as the one which is the furthest from the worst, but these two characteristics turn out to be contradictory. Defending monarchy as the best form of government, he condemns tyranny as the worst, but in the context of his criticism of the rule by many, tyranny turns out to be an acceptable solution in spite of everything, because the basic weakness of the rule by many is precisely that it is, in a sense, underpinned by tyranny.

Characteristically, this contradiction seems to correspond to certain inaccuracies in Aristotle's Politics, for in both cases it is the result of the arguments put

39 St. Thomas Aquinas, De regimine, Book I, Chapter XV, p. 40-41.

40 St. Thomas Aquinas, De regimine, Book I, Chapter VI, p. 16. 
forward by a philosopher and a 'political scientist' ${ }^{41}$. For when St. Thomas speaks of the best form of government, he emphasises the unity of power, and when he speaks of the worst form of government, he stresses that it also destroys social peace, which tyranny itself does not upset, unless it is 'so excessive that it ravages the whole community'. Regarding the government as the so-called empirical Aristotle does in the middle books of his Politics, i.e. in terms of the best possible form of government, St. Thomas thus views a mild tyranny as a lesser evil than all forms of government by many - good ones as much as bad ones - for the good ones are not permanent, after all. It is at that point that St. Thomas' division of forms of government is practically flattened into one quantitative criterion concerning the government. Since any good government may become perverted, one needs to think of each one in terms of the Aristotelian middle way; real-life forms of government are not so good as to work towards the common good of the community as a whole; nor are they so bad as to work only towards the good of the rulers.

A rule of one will be better than other forms of rule, however, as it is less threatened with disintegration, and poses a lesser threat to the peace of the community. St. Thomas has no doubt about it, all the more so because government by one - and this argument may be attributed to all authors of 'mirrors for princes', even if they do not state it explicitly - is also more susceptible to learning; accordingly, he offers advice on 'how a community should conduct itself in relation to him so as to remove the opportunity of his becoming a tyrant' (this is part of the title of the following chapter). This advice may be understood - as it was indeed understood by the author's contemporaries - as a call for building a mixed form of government: for sharing, once again following Aristotle's example, the rule of the kingdom, and limiting the monarch's rule in such a way as to remove from

41 In the literature this is often explained as St. Thomas' text being unedited. Mateusz Matyszkowicz, the editor of the most recent Polish edition of the treatise, sees in it only St. Thomas' conditional support for monocratic rule - a tyranny is also a monarchy - as well as his pragmatism. A mild tyranny is to be ultimately better than polyarchy, i.e. a rule by many, because it does not destroy the people, only the ruler himself; St. Thomas' ideal would be a monarchia mixta, with the ruled being involved in the exercise of power; cf. Mateusz Matyszkowicz, 'Komentarz' in: Tomasz z Akwinu, O królowaniu, p. 163-199 and p. 319-323. St. Thomas' indecision has also been interpreted as an expression of his philosophy's relative independence of theology, characterizing his political thought; cf. Jacek Grzybowski, Miecz i pastorat. Filozoficzny uniwersalizm sporu o charakter władzy. Tomasz z Akwinu i Dante Alighieri (Kęty: Wydawnictwo Antyk, 2006), p. 325. 
him the temptation of establishing a tyranny, after choosing the right person for that office in the first place ${ }^{42}$.

This preference for the rule of one man may not, therefore, be justified by the Aristotelian idea of a man surpassing the others in virtue, or a great-souled man, in whom power should be vested, if only an individual like that lived in the world, as it is in fact an expression of St. Thomas's minimalism or pragmatism, rather than of the maximalism characteristic of Aristotle. A monarch's rule is the most effective rule in achieving the community's moral goal. Aristotle's normative philosophy does not give St. Thomas any additional argument in favour of one-man rule, but such an argument is supplied by theology.

The same thing becomes clear from a consideration of the order of Divine providence, which disposes all things for the best. For goodness arises in things from one perfect cause, as from the working together of everything that can assist in the production of good; whereas evil arises singly, from individual defects. ${ }^{43}$

Building their state on earth, people cannot do anything better than be guided by heavenly models. This is where philosophy gives way to political theology; the institution of representation appears in mediaeval political thought because of a connection between the earthly order and the eternal order.

These two orders are connected with each other not only through the ultimate goal of human life, which is not of this world, a goal that the earthly government should also serve to achieve, but also through the origins of that government. This civil power comes from God, just like spiritual power ${ }^{44}$. The divine origins of power are not only its legitimisation, but also the source of the rulers' obligations vis-à-vis the ruled; even when St. Thomas addresses the subject of the origins of power, he soon proceeds to discuss its functions. 'The king in his kingdom is like the soul in the body and God in the world ${ }^{45}$. Like God in the universe, the ruler on earth institutes law and order; he should therefore rule justly, graciously and kindly. And if he discharges the duties of his difficult office well, a reward commensurate with his labour awaits him in heaven; 'good kings

42 Cf. St. Thomas Aquinas, De regimine, Book I, Chapter II, p. 17.

43 St. Thomas Aquinas, De regimine, Book I, Chapter IV, p. 12-13.

44 St. Thomas is of course far from calling the king 'God and Christ through grace', as the author of an anonymous treatise did. He uses the expression Deus per gratiam exclusively to describe God Incarnate; cf. Matyszkowicz, 'Komentarz', p. 221. Commenting on another excerpt from the treatise, Matyszkowicz observes, however, that the ruler should become God's image or icon; cf. p. 27.

45 St. Thomas Aquinas, De regimine, Book I, Chapter XIII, p. 36. 
are most acceptable to God and worthy of the greatest rewards from Him'46. Importantly, St. Thomas does not seek to convince his readers that God Himself has authorised His anointed to discharge these functions in His stead. In this respect, Christian kings do not occupy a privileged position as compared to the pagan rulers of old; just like them, they also sometimes yield to temptations and forget about their vocation ${ }^{47}$.

That is why in the matter of superiority and subordination between spiritual and secular power, St. Thomas cannot invoke the argument of their source. What is decisive for this relationship between the spiritual and secular power is the hierarchy of the goods that each kind of power guides people towards, as well as of the laws (natural law and man-made law) described by St. Thomas as roads leading to the respective end $s^{48}$. For the goal of the community is a virtuous life, but the aim of a virtuous life is salvation. Even though in the Old Testament the priests were subject to royal laws, the advent of Christ changed this order of things.

But under the new law there is a higher priesthood, by which men are conducted towards heavenly goods; and so, under the law of Christ, kings must be subject to priests. For this reason it came about by the wondrous dispensation of Divine providence that in the city of Rome, which God foresaw would be the principal seat of the Christian people in time to come, the custom gradually grew up that the rulers of the city should be subject to the priests ${ }^{49}$.

Irrespective of the form of government, no matter how far secular power resembles God's power, spiritual power will always be higher than secular power,

46 St. Thomas Aquinas, De regimine, Book I, Chapter X, p. 29.

47 Kantorowicz quotes a statement made by the Emperor Frederic II (adding further on that the imperial chancery later toned down this haughty and arrogant language), who spoke of himself in words which, according to Seneca, could have been uttered by the Emperor Nero: 'Have I not been chosen to act on earth as vicar of the gods? I am the arbiter of life and death for the peoples. What each man's lot and state shall be is laid into my hands. And what Fortune would bestow on any mortal, she makes known through my mouth' Kantorowicz, The King's, p. 116.

48 Naturally, both kinds of power have different types of authority: spiritual power has the right to interpret the doctrine and administer the sacraments, while temporal power has the proper authority for dealing with earthly affairs and the power to exercise coercion; thus, the former has higher authority, while the latter has greater power; cf. Matyszkowicz, 'Komentarz', p. 293. This author also includes a useful overview of the opinions of authors writing on the subject before St. Thomas, cf. p. 270-275.

49 St. Thomas Aquinas, De regimine, Book I, Chapter XV, p. 42. 
as spiritual goods are higher than worldly goods ${ }^{50}$. Thus St. Thomas' argument on the superiority of spiritual power over secular power is comprised in its entirety in the philosophical - i.e., secular - Aristotelian scheme.

That is why, St. Thomas does not need any additional arguments to settle the dispute, such as those usually invoked by advocates of papal supremacy, i.e. arguments of a historical nature: the receiving of power by kings from the hands of priests or the donation of Constantine. Obviously, one may say it would be simply tactless towards the addressee, a secular ruler, to treat this treatise as an opportunity to present a complete argument on this controversial subject. Characteristically, St. Thomas does not introduce any arguments of a theological nature, justifying the superiority of spiritual power over secular power exclusively in terms of its function, rather than its origins.

The only occasion on which St. Thomas goes beyond the Aristotelian scheme is when he defines the goal of a happy life, lying outside the state, even though one may say that even then he only wants to extend this scheme to goods that it did not and in fact could not encompass. 'A fulfilment of human nature', writes Matyszkowicz, 'does not occur in the secular civitas, but in the Church, because it is the Church that guides man towards eliminating all his deficiencies ${ }^{51}$. Power in the Church is legitimised, however, through its origins, and is exercised, thanks to the institution of representation: it is a scheme that is in no way compatible with Aristotle's thought. St. Thomas manages to keep his argument coherent at the expense of 'overlooking' this obvious point.

The argument of being given power directly by God is too natural, however, not to come up in this dispute; it serves the advocates of the superiority of spiritual power to neutralise any Divine connotations of secular power. They will keep recalling that Christ personally handed down spiritual power only to Peter and his successors; in the case of secular power nothing like that occurred: the Son of God exclusively reaffirmed that while the imperial power was legal, neither $\mathrm{He}$

50 That is why, like Matyszkowicz (cf. Matyszkowicz, 'Komentarz', p. 260-270), I do not agree with an interpretation of St. Thomas' thought which considers the fragment speaking about the subordination of earthly power to spiritual power to be inauthentic or inconsistent with his output as a whole.

51 Matyszkowicz, 'Komentarz,' p. 287. Characteristically, St. Thomas never wrote a treatise on the Church; even in his Summa Theologica there is no separate part devoted to it, perhaps because, as Joseph P. Torell explains, he sees the presence of the Church wherever there is any kind of relationship between man and God. On the other hand, he did not write any major treatise on politics either; cf. Grzybowski, Miecz i pastorat, p. 356,335 . 
nor His Father has given it to any of the emperors. Thus, if secular power should claim divine sanction, it must agree to the mediation of those who received their power directly from the Maker. Precisely for this reason, the secular party in the dispute will first challenge the apostolic succession, i.e. the representative character of papal power, only to reach itself subsequently for the idea of representation in order to legitimise secular power without recourse to supernatural powers. This task will fall to Dante and Marsilius and will require a further modification of Aristotle's scheme.

\section{Power in the service of the unity of humankind: Monarchy by Dante Alighieri}

In Dante's Monarchy there is not a trace of ambivalence concerning forms of government; everything that is good is a unity. Thus, monarchy is indisputably the best form of government: an empire ruled by one ruler, which the author, an ardent supporter of the emperor, places higher than feudal kingdoms:

Temporal monarchy, then, which men call 'empire', is a single sovereign authority set over all others in time, that is to say over all authorities which operate in those things and over those things which are measured by time $\mathrm{e}^{52}$.

A universal monarchy ensures peace to the people of the empire, justly adjudicates on any contentious matters between the princes, and finally directs human efforts in one and the same direction. Government must be a unity in any form of government, whether correctly or incorrectly shaped; otherwise, the state will be divided and ultimately destroyed as a result of infighting. The rule of one is also by nature the closest to justice, for if the whole kingdom belongs to the monarch, he is the most immune to greed out of all the rulers ${ }^{53}$. Under one monarch's rule, the whole of humanity also enjoys the greatest freedom, for only the one who exists for himself is free, and he exists for himself when he is not incapacitated by defective democratic, oligarchic or tyrannical rule. The monarch will not allow such incapacitation because he loves the people, and he regards his power on earth as service. And in this he is like God Himself, One, even though within the Trinity. It was not an accident that Christ was born into the world under the rule of Augustus, the monocrat.

Mankind also needs one ruler, because it has a universal goal that it may achieve only by concentrating all its efforts that are now being squandered in

52 Dante Alighieri, Monarchy, Book I, Chapter II, 2, p. 4.

53 Dante Alighieri, Monarchy, Book I, Chapter XI, 11, p. 40. 
nonsensical fighting. Because of this infighting, mankind does not realize what it is capable of. The unity of the human race is a prerequisite for its 'intellectual potentiality' to reveal itself fully. Universal human reason, Dante argues in the spirit of Averroes, will then achieve its full capacity for action, its perfection. This perfection is of a spiritual, but not of a religious nature; it imitates the divine perfection, like the earthly order imitates the heavenly order. Dante does not postpone this moment to the time of Christ's Parousia, but until the time of the unification of mankind under secular rule ${ }^{54}$.

The existing spiritual order, headed by the pope, has equally universal aspirations; Dante regards the papal bull Unam sanctam by Pope Boniface VIII as evidence; it is this document that directly provoked him to take a stance. That is why, the author of Monarchy - let us pass over the political context of his criticism of the papacy here argues that the Church is a unity of a different kind, which may not reach its fullness until the end of time, exclusively in the eschatological dimension. Dante's argument must therefore stress the religious and political dualism which St. Thomas wanted to cover by a single Aristotelian scheme, combining within it, as far as it was possible, Reason and the Revelation. Dante has to separate them, drawing the dividing line between them in the human soul.

It is only the conclusion of his treatise, however, that reveals his intention. Providence itself, Dante claims, has set before man two goals at which to aim, namely:

happiness in this life, which consists in the exercise of our own powers and is figured in the earthly paradise; and happiness in the eternal life, which consists in the enjoyment of the vision of God (to which our own powers cannot raise us except with the help of God's light) and which is signified by the heavenly paradise. Now these two kinds of happiness must be reached by different means, as representing different ends. For we attain the first through the teachings of philosophy, provided that we follow them putting into practice the moral and intellectual virtues; whereas we attain the second

54 That is why, Eric Voegelin sees distinct indications of Gnosticism in Dante's thought. 'Again, as in the Unam Sanctam', he writes, referring to Dante's views expressed in the Convivio, 'we are faced with the attempt of evoking a spiritual realm in historical existence, and again the method of realizing the realm is the creation of a new spiritual nobility. The key to understanding Dante's conception is his transfer of the idea of nobility from the feudal nobility of the blood to an intellectual nobility of the person'. Cf. Eric Voegelin, The Collected Works of Eric Voegelin, XXII, History of Political Ideas, IV, Renaissance and Reformation (Columbia and London: University of Missouri Press, 1989), p. 209. 
through spiritual teachings which transcend human reason, provided that we follow them putting into practice the theological virtues, i.e. faith, hope and charity ${ }^{55}$.

As people are imperfect, they need two guides: one is the Supreme Pontiff, and the other is the emperor, who, following the teachings of philosophy, guides mankind towards temporal happiness, towards the 'earthly paradise. He owes filial reverence to the Pope, but nothing more, as both kinds of power derive from God and it is only that 'this earthly happiness is in some sense ordered towards immortal happiness ${ }^{356}$.

Thus, if both supreme powers remained each within its own domain, there would be no conflict between them. The problem is, however, that the pope pretends to earthly power, invoking false historical and theological arguments ${ }^{57}$. The former have their source in a donation allegedly made by Constantine. By Dante's time, its falsehood had not been exposed, so he only claims that Constantine was not in a position to give away the privileges of empire, as he would thus be acting against his own empire - the very essence of which is unity and indivisibility. On the other hand, nor was the Church in a position to accept this donation, for according to the Gospel it may not receive temporal goods at all. Similarly, the vicar of Christ may not receive anything, unless in his capacity as the administrator of Church property, with the donations being allocated to the poor ${ }^{58}$. Equally illegitimate was the crowning of Charlemagne if the Pope had made it conditional on the emperor defending the Church and subjecting himself to ecclesiastical rule; in such a case, it was nothing but an act of usurpation. Otherwise, Dante observes, if the emperors have placed their protégés on the throne of the bishop of Rome, may they for this reason alone claim superiority over the papacy?

55 Dante Alighieri, Monarchy, Book III, Chapter XVI, 7-8, p. 92.

56 Dante Alighieri, Monarchy, Book III, Chapter XVI, 17, p. 94 . Alessandro P. d'Entrèves writes that Dante's Monarchy is characterised by a 'temporary forgetfulness' of a fundamental Christian idea saying that mankind cannot be saved and redeemed without outside help, cf. Alessandro Passerin d'Entrèves, Dante as a Political Thinker (Oxford: Clarendon Press, 1952), p. 51.

57 Pope Gelasius I's doctrine of two swords is discussed in a broad context by Tomasz Żyro; see Tomasz Żyro, Wola polityczna. Siedem prób z filozofii praktycznej (Warszawa: Wydawnictwa Akademickie i Profesjonalne, 2008), p. 81-83; 156. Żyro argues that Dante significantly modified that doctrine or indeed 'incapacitated it' by invoking arguments taken not from the Bible, but from Roman law, as codified in the Code of Justinian.

58 Cf. Dante Alighieri, Monarchy, Book III, Chapter X, p. 80-83. 
In order to prove that any kind of superiority is out of the question, Dante does not content himself with demonstrating that spiritual power tries to appropriate to itself the right to exercise secular power; he also argues that the pope, being merely part of the Church, has placed himself above all of it. Thus, within the Church itself, he is not the one that he professes himself to be; for he invokes tradition that was established several centuries after the founding of the Church. This is what the decretists and all those supporting the pope, 'who, having the devil as their father, yet profess themselves to be sons of the $\operatorname{church}^{59}$, seem to fail to understand, bandying around arguments derived from the Old and New Testament. They seem to place the greatest importance on the one taken from the Book of Genesis: God created the sun to rule the day and the moon to rule the night, the latter taking its light from the sun; in the same fashion, while secular power has its own domain of government, it derives its authority from spiritual power. Dante demonstrates the logical deficiencies of this reasoning - not a difficult thing, obviously - but even so his own argument will be convincing only to those who, like himself, derive both kinds of power directly from God.

In the context of this book, the argument against the decretists is of special importance ${ }^{60}$, in which Dante argues that the successor of St. Peter may not have power equal to divine power. This is not only because there is simply no such power on earth, but also because it is the rule of all nature, given that no man can work miracles, i.e. violate natural laws. For the pope, the vicar of Christ, did not receive any power of his own.

A prince's authority belongs to a prince only as something for his use, for no prince can confer authority on himself; he can accept it and renounce it, but he cannot create another prince, for the creation of a prince is not dependent on a prince. If this is the case, it is clear that no prince can appoint a vicar to take his place who is equivalent to him in all things ${ }^{61}$.

Placing himself in the role of the Maker, the pope quite simply commits a usurpation, for the prerogatives that he claims for himself resemble the sovereign prerogatives of God Himself. But could not Dante have said the same thing

59 Cf. Dante Alighieri, Monarchy, Book III, Chapter III, p. 66.

60 Unlike the thinkers of the Reformation era, however, Dante did not argue against canon law; cf. d'Entrèves, Dante, p. 55. Even though he often changed his mind, he never questioned the pope's spiritual power, either; cf. John Woodhouse, 'Dante and Governance: Contexts and Contents', in: Dante and Governance, ed. John Woodhouse (Oxford: Clarendon Press, 1997), p. 3.

61 Dante Alighieri, Monarchy, Book III, Chapter VII, 7-8, p. 75. 
about imperial power? With respect to his God-given power, is not the emperor a vicar, too?

The argument concerning imperial power is preceded in the treatise by considerations on the papacy, and this order is fortuitous in that it allows Dante to omit this problematic question. For Dante wants to prove that - even though power was not vested in the emperor as symbolically as it was in Peter - the secular empire has an equally strong legitimacy. The imperial power is legitimate because the Roman Empire itself existed legally. The Roman people acquired the prerogatives that the monarch is entitled to in an absolutely legal way, not by usurpation, because they were the noblest people. To bear out this claim, Dante takes extracts from ancient sources: from Virgil's Aeneid, Lucan's On the Civil War and Livius' History of Rome. All the cited facts are meant to show that the Empire had developed with God's support. Even though the author of Monarchy does not expressly say so, this indirect evidence of the Roman people having been chosen by God is intended to convince the reader that secular power is founded on a sign of divine intervention that is no less clear than Christ handing over the keys to the Apostle Peter.

The ancient Romans had earned God's favour because they were guided by law, and law guides people towards the common good (if it fails to do so, it cannot even be called law). For the ancient Romans only fought just wars, to defend their provinces and their allies' lands, and they lawfully held the territories that they had acquired by combat ${ }^{62}$. By Divine Providence they had extended their rule to the lands of other peoples, extending law to the incorporated territories, and had extended protection to the defeated rather than ruled them; 'the Roman people in conquering the world had the public good as their goal' ${ }^{\text {'3 }}$. Thus, according to Dante, ancient Rome represented the unity of mankind and prepared the world for Christ, as Charles Davis claims $s^{64}$, but also, equally, it prepared the world for the Perfect Man, who would unite the Christian world.

62 Cf. Dante Alighieri, Monarchy, Book II, Chapter IX, 1, p. 53. According to Peter Armour, Dante firmly believed that God Himself created the Empire with the hands of the Romans; cf. Peter Armour, 'Dante and Popular Sovereignty', in: Dante and Governance, ed. John Woodhouse, p. 42.

63 Dante Alighieri, Monarchy, Book II, Chapter V, 18, p. 44.

64 Cf. Charles T. Davis, Dante and the Idea of Rome (Oxford: Clarendon Press, 1957), p. 36-40. The order that Dante writes about is founded on the idea of harmony of the three elements represented by Rome: the historical city chosen by God to unite mankind, the capital of the Christian empire and the head of the Christian Church; cf. Davis, Dante, p. 234. 
The problem is, however, that Dante does not derive the emperor's power from the rule of the people of Rome ${ }^{65}$. There is evidently no conjunction between the three elements of his thought: the best form of government, i.e. monarchy, the imperial power coming directly from God, and an apology of the Roman Empire. God appointed the Romans to rule the world and the Empire is evidence for that, but imperial power comes directly from God. Thus, the emperor and his title to rule are suspended, as it were between God and the people. He cannot be said to rule the world in place of God: there are no premises to claim so. Unable to give the secular ruler the function of God's representative on earth, Dante has to content himself with a general formula saying that secular power, just like spiritual power, and, one might say, everything on this earth, comes directly from God.

However, why can Dante not explicitly make the emperor the representative of the people of Rome? Obviously, this would be far removed from historical truth - for it was not the people who elected the emperors - but in ideological disputes the truth has never had any major, let alone decisive, importance. However, introducing the idea of representation into this dispute would have considerably lowered the position of secular power vis-à-vis spiritual power, as the former would then have been exercised in the name of the people, and the latter in the name of God Himself. When both kinds of power come directly from God, they remain in ideological balance ${ }^{66}$. God gave power to the pope and the emperor, but neither of them wields power in His name. Consequently, in Dante's thought there is no open ideological conflict between the top-down representation of God and the bottom-up representation of the people, for there is no idea of representation in it at all. In fact, it cannot appear there, for until the people replace God in the role of the supreme power, they will not be able to compete with Him as the source of any kind of power. This breakthrough would only be brought about by the modern revolutionary doctrine.

65 According to Armour, one may infer that according to Dante the rule of the people of Rome had already been handed over to Caesar Octavian Augustus himself, and this state of affairs was later sanctioned in the Code of Justinian, even though the author of the Monarchy does not state this explicitly; cf. Armour, Dante, p. 38-39.

66 Armour emphasises, however, that according to Dante the sovereignty of the people does not consist in the choice of the ruler, but only in legislative authority; this may also explain why Dante does not regard the electors of the emperor as representatives of the will of the people: all they do is reveal the decrees of Providence; cf. Armour, Dante, p. 37, 42 . 


\section{Power by the will of God and the people: The Defender of the Peace by Marsilius of Padua}

Marsilius of Padua knows how to bypass this problem, however, as he considers the council, rather than the pope, to be the supreme authority within the Church. He denies the pope the status of the representative of God before the Church, granting the right to represent the Church before God to the council. He thus reinstates the unity of human nature, even though he cuts it down to size so that man can satisfy all his needs, including the spiritual ones, within the bounds of his political community. He elevates secular power above spiritual power, but he gives each its scope of competence in an 'amicable' manner, and places both in a position to guard this universal moral and political order.

The argument in which Marsilius, invoking the authority of the Bible (mainly the apostolic teachings), as well as the instructions of the doctors of the Church, deprives the pope of the function of the representative of God on earth is very extensive, but it can be abbreviated to several statements ${ }^{67}$. Firstly, because of the spiritual character of priesthood all apostles had equal authority and Peter had no power over them, merely an honorary precedence. Secondly, for this reason the bishop of Rome ${ }^{68}$ has the priestly authority, i.e. the power to celebrate the Eucharist and to grant an absolution of sins, precisely to the same degree as any other bishop and indeed any simple priest. Thirdly, the bishop in the community of the first Christians, elected by that community, did not enjoy any higher authority or greater power than other priests. This is precisely the human element of the priestly office, secondary to 'essential authority'. The priests receive this authority

from God or Christ without intermediary, even though this is together with a certain human ministration as if in preparation, such as the laying on of hands and a verbal pronouncement; which perhaps effect nothing at all in this regard but are premised in this way as a result of a certain agreement or divine ordinance ${ }^{69}$.

Thus Marsilius challenges the consecration doctrine, which served to justify the superiority of priestly power over secular power in the early Middle Ages: nothing

67 Cf. Marsilius of Padua, The Defender, Discourse II, Chapter 15, 4-10; Chapter 16, p. 312-334.

68 Marsilius also claims that it is impossible to prove on the basis of Holy Scripture that Peter was the bishop of Rome; cf. Marsilius of Padua, The Defender Discourse II, Chapter 16, 16-18, p. 332-334.

69 Marsilius of Padua, The Defender, Discourse II, Chapter 15, 10, p. 318. 
at all follows from the fact that it is the bishops who consecrate the kings. After this conclusion, the author goes on to expose the papal authority as usurpation.

For Marsilius considers the primacy of the bishops of Rome to be merely a matter of historical circumstances, rather than the result of some divine intention; a certain custom has become established, which they have used to expand their authority. There were simply more Christians in Rome, they were better educated, it was there that St. Peter and St. Paul had stayed; finally it was from Rome that answers first came to the questions asked by Christian communities, and later friendly instructions addressed to them. This met with the gratitude of other churches, and the bishops of Rome, as their authority grew, began, from the time of Constantine, to issue decrees binding for the entire community of the confessors of Christ. In an extensive historical and theological argument, Marsilius argues that they had no right to do $\mathrm{so}^{70}$ : no canonical book of Scripture mentions such a practice, and the historical evidence according the formal leadership of the Christian world to them is false.

On what basis, therefore, does the Pontifex Romanus pretend to full power? It is impossible to deduce that from the words of Christ addressed to Peter, 'Feed my sheep', recorded in the gospel according to John, and 'I will give you the keys of the kingdom of heaven' in the gospel according to Matthew. But it was on these alleged biblical bases, Marsilius claims, that the bishops of Rome have extended their authority over the entire Christian community, taking advantage of the piety of passive people, not conversant with the Law of God, and of their fear of eternal damnation. The bishops of Rome had been merely part of the Catholic Church, but they have placed themselves above the whole of it. [s. 42]

Usurping the whole power to itself, the papacy has 'infected and - if one may be allowed to say so -', Marsilius states a reservation, 'corrupted the entire mystical body of Christ'. The successive popes have corrupted and limited the legitimate procedure of election of bishops by spiritual and lay Christians, and have themselves appointed young and inexperienced people to those offices, who were unaware of God's teachings, or even the mentally ill and habitual offenders. Most often, however, they have granted those honours to advocates, as they were most efficient in seeking to preserve and appropriate temporal goods. For that matter, there have not been many doctors of theology among the popes themselves advocates of a similar kind have usually turned out to be more useful for that function. This has become a widespread practice in Christendom: in Marsilius' time, it is ruled by people who do not care for the purity of the doctrine, but

70 Marsilius of Padua, The Defender, Discourse II, Chapter 19-20, p. 360-375. 
for temporal goods, committing acts that scandalise the people and win Christ's Church enemies. Marsilius regards the Roman curia as the terrible statue of which Nebuchadnezzar speaks in the Book of Daniel, but he believes that the author's prophecy will come true and 'upon this statue shall a stone fall that was cut out from the mountain without hands ${ }^{31}$. God, in His grace, will give the people a king who will destroy the curia; and that king will be, of course, the Defender of the Peace.

But it will not be a secular ruler who will begin this conflict. It has already been started by the papal authority, seeking to expand its earthly domain beyond the limits of the Church. Bishops of Rome, not content with the power they held, 'have sought (against the command or counsel of Christ and the apostles) the pinnacle of secular affairs', and have begun to pass laws separate from those of 'the universal body of citizens'; they have exempted themselves from the jurisdiction of those laws, and this has led to the situation of diarchy and, consequently, social discord ${ }^{72}$. The papacy has had, Marsilius argues, enough foresight and cunning to give its usurped power the appearance of legality; it has not called its 'oligarchic ordinances "laws"'; rather, it calls them 'decretals' or 'canon law', and has used them to commit countless enormities within the civil order against divine law and human law.

For it is the root and origin of the pestilence in the Italian realm, from which all the scandals have germinated and develop, and while it remains there will never be an end to the civil discord there. ${ }^{73}$

In its usurper inclinations, the papacy would like to subjugate even the emperor to itself so as to subjugate the remaining countries all the more easily. Using the symbolism of placing the diadem on the emperor's head, the pope in fact attributes to himself the privilege of electing him, even though according to the law, this privilege is reserved for the college of electors; placing the diadem on the emperor's head may not be anything more than recognising the election result $^{74}$. To the argument that it is the sign of the pope's concern that a heretic should not sit on the imperial throne, Marsilius replies that there are three venerable archbishops among the electors, each of whom has the same priestly dignity as the pope. Even if a heretic should occupy that office, or the ruler should fall

71 Marsilius of Padua, The Defender, Discourse II, Chapter XXIV, 17, p. 430.

72 Marsilius of Padua, The Defender, Discourse II, Chapter 23, 11, p. 415-416; cf. also Discourse I, Chapter 19, 12, p. 135-136.

73 Marsilius of Padua, The Defender, Discourse II, Chapter 23, 11, p. 415-416.

74 Marsilius of Padua, The Defender, Discourse II, Chapter 26, 5, p. 452-453. 
into heresy, the right to depose him is not vested in the pope, but in a general assembly of all those who are under his authority. On the other hand, such an assembly may - and should - take full power away from a pope who is evidently using it to the detriment of Christianity.

Reinstating the supremacy of the council over the pope would therefore be nothing but reinstating the state from before the Roman usurpation. Invoking the Bible, Marsilius recalls the time of the apostles: disputes concerning the main articles of faith, cult and order were settled within the Church in a collective manner, involving laypersons who were more expert in Scripture. At later, more important councils, emperors or their high officials also attended and took part in the proceedings, explaining unclear passages in the Bible; of course, Marsilius does not regard it as interference by secular authorities in ecclesiastical affairs, but as a proof of the fundamental importance of the institution of the council in the life of the entire Christian community. The council is a collective body of all Christians, even though only their representatives actually participate in it, delegated by all provinces and notable communities of the world. These people, 'representing the universal body of the faithful through the said authority granted them by those other universal bodies ${ }^{75}$, should convene in a convenient place according to the decision of their majority.

Even though the faithful are thus obliged under the Divine law, it would be unnecessary, impractical and indeed impossible for all to come to the council, particularly as this duty is binding upon various people to various degrees. Naturally, priests should attend, as it is their task to preach the Word of God and watch over the purity of the Christian doctrine, but also laypersons endowed with authority, 'expert in divine law'. Lawmakers, too, should participate in the proceedings of the council, for it is their responsibility to guarantee the participants' security and provide them with material goods, or even, if necessary, make those who shirk from coming arrive, if their presence could be conducive to the common good ${ }^{76}$. Therefore, Marsilius deems it necessary for the body which is the representative of the People of God to have some degree of representativeness.

Most importantly, it has to include people capable of discovering God's truth, given that it is predestined for that purpose. The author of the treatise observes with a sneer that the presence of lay Christians is necessary, because the priests of his era are more ignorant than laypersons in matters of faith, and it is a 'prevailing multitude' of the faithful that should ultimately decide on matters of the

75 Marsilius of Padua, The Defender, Discourse II, Chapter 20, 2, p. 368.

76 Marsilius of Padua, The Defender, Discourse II, Chapter 20, 2, p. 368. 
highest importance to the Church ${ }^{77}$. Nobody should do this on his own, given that even the apostles dared not do so. The pope is the least entitled to do this, of which he has given proof on numerous occasions, most recently in his bull Unam sanctam (Marsilius does not deny himself the occasion to ask, moreover, where Holy Scripture speaks of the king of France, to whose lands the pope does not intend to extend his jurisdiction).

Among the crucial prerogatives of the council that the pope has usurped for himself is the right to excommunicate. This is the right 'of binding and loosing', which Christ admittedly gave to the priests; however, that right is not vested, as Marsilius repeatedly emphasises, in any single individual, in any bishop or parson or in any colleges set up by them: it is vested exclusively in the council. Even though Marsilius writes about excommunication as an 'anathema' imposed on sinners, 'so that there is nothing to stop them hurtling to the destruction of $\sin ^{78}$, he pays more attention to its social aspect: for ultimately it is an act of exclusion of the confessors of Christ from among the temporal community. That is precisely why individuals must not decide on an anathema: they occasionally do so unwisely or wickedly, causing a great scandal and posing a threat to peace in the entire Christian world.

In a similar vein, Marsilius argues that without the council's consent (or without the consent of the secular ruler, which will be discussed below) no bishop has the right to appoint anybody to ecclesiastical offices, or grant him benefices or the right to teach; this would place entire provinces at risk of remaining under heretic rule; heresy on the part of the ruler means the same as an unjust excommunication: a threat to peace. The case is similar with the canonisation and cult of the saints, which may also be either conducive or detrimental to social peace. As a matter of fact, all of Marsilius' arguments are intended to lead, in one way or another, towards the conclusion that the council seeks the unity of the Church, while the pope destroys it with his claims. Importantly, on those matters on which the council cannot speak directly, the emperor will do so on its behalf, as preserving the unity of the Christian world is also his responsibility.

77 Leo Strauss interprets this passage as follows: that the Church should be ruled by a spiritual aristocracy (now it is ruled by an oligarchy) and the voice of ordinary Christians should not have much importance in it, that it should be reduced to ratification procedures; cf. Leo Strauss, 'Marsilius of Padua, in: History of Political Philosophy, ed. Leo Strauss and James Cropsey (Chicago and London: The University of Chicago Press, 1987), p. 286-287.

78 Marsilius of Padua, The Defender, Discourse II, Chapter 6, 11, p. 202. 
Thus, what kind of role has the pope to play in the Mystical Body of Christ? Who is he at the ecumenical council, and who is he outside its proceedings? The question that Marsilius considers is, as stated in the title of Chapter 22, Discourse II, closing his argument, 'In what way the Roman bishop and his church may be head and principal of the rest; and on account of what authority this belongs to them.' Even though he does open his argument by saying that it is 'expedient and appropriate' for one bishop or church to have priority or principality over all the other bishops and churches, he immediately adds that he must not have the kind of power over the Church that the Roman curia wants to exercise. Based on Holy Scripture, it is impossible to prove that any one bishop may be the leader of the Church because of his power and authority. For if the Church had a principal of that kind, his presence would always breed disputes, depravity and scandals. Thus, based on the same premise - peace among Christians - Marsilius' argument runs parallel, as it were, to the argument of St. Thomas and Dante; they argue that the unity of political power is the condition of that peace, while he claims that it is the lack of spiritual power vested in one individual.

Does the Church, therefore, not need a 'principal' at all? The Church understood as the Mystical Body of Christ, 'the universal body of faithful believers who call upon the name of Christ, and of all the parts of this body within any community, even the household ${ }^{79}$, certainly does not need one. Christ Himself is its principal. For day-to-day administration, it only needs someone appointed by the general council or a secular but faithful lawmaker:

that if an emergency of the faith or an evident need on the part of the faithful has arisen and is reported to him, on account of which it seems wholly expedient to call a general council, it is his duty, although only after deliberating with his college of priests (whom the faithful human legislator or general council has willed should be his associates for this purpose), to make this known and signal it to the faithful legislator who lacks a superior: at whose coercive command the council should assemble in the way that we have said ${ }^{80}$.

Thus, the papacy does not in any way represent the council before the faithful. Speaking in contemporary language, it should not, according to Marsilius, be anything more than a delegated permanent secretariat deprived of any

79 Marsilius of Padua, The Defender, Discourse II, Chapter II, 3, p. 145. Marsilius writes further: 'Again, in another signification [of the Mystical Body of Christ - A.W.] - the truest and most proper of all according to the original application of the term or the intention of those who originally applied it, even if it is not so widespread or consistent with modern usage?

80 Marsilius of Padua, The Defender, Discourse II, Chapter XXII, 6, p. 394-395. 
decision-making power; for the councils are to be convened by a secular legislator. Incidentally, this office need not be held by the bishop of Rome; Marsilius perversely argues that it should be held by the most virtuous man, assisted by an enlightened 'college of priests'. It is only because of the authority of the apostles Peter and Paul and the merits of the first bishops that it customarily remains in Rome. If, however, this bishop or his college behaves in a way that is 'too perverse or negligent' in the discharge of his/its responsibilities, the other churches may ask the faithful secular legislator to convene a council in order to decide the matters that the papal office is unable to resolve.

In order to prove the superiority of the council over the pope, Marsilius ultimately must, therefore, deprive his office of any authority whatsoever; speaking more precisely, he has to prove that the pope owes his entire authority to the council, and draws none directly from God. It is not an easy task in so far as the council's superiority may follow from nothing but the practice of early Christianity, while Christ Himself seems to prove the superiority of the papacy by symbolically giving Peter the keys. These two symbolic facts have an entirely contradictory significance; they cannot even be juxtaposed one against the other, as one questions the other. This dispute cannot, therefore, end in any kind of compromise. And if one can say that the decretalist party won at the council of Constance, then the Reformation was, as it were, a victory of the conciliarists delayed by one century.

The doctrine of the representation of the Church was certainly not carefully elaborated by Marsilius. By making the council a representation of the people of God, he was already, in spite of everything, touching upon the fundamental ambivalence of representative bodies, which, on the one hand, are to reproduce the represented communities and, on the other, are to lead them. Thus, on the one hand, these bodies should be representative, and on the other hand, there should be more outstanding people in them. However, this is not a question that would particularly occupy Marsilius; his doctrine of representation by the council is, as it were, a by-product in the ideological dispute with the papacy. At the same time, Marsilius does not stress the council's representative character by invoking its origins; the superiority of the council's resolutions over papal decrees still follows from Aristotle's logic, i.e. from the superiority of the whole over a part, as the council is the representation of the People of God as a whole, and the papacy only a part of it. Marsilius invokes this argument in a broader context only in determining the mutual relations between the Church and the state, when the state is that whole to which the clergy belongs as one of its parts.

Underlying Marsilius' argument on secular power are premises that were self-evident to mediaeval people. He acknowledges that all power comes from 
God, who can hand it over directly, as he did to Moses, when he made him the leader of Israel, or indirectly, through the people who elect their leaders, or through heredity. In the latter case, God is a remote cause, causa remota. Searching for the beginnings of power, Marsilius also invokes Aristotle. He gives a special sense to Aristotle's division of forms of government into 'true' and 'perverted' ones, because to the criterion of the manner of governing (true forms of government are balanced, while the perverted are not), he adds the criterion of their origins: the former are instituted with the consent of the citizens, while the latter emerge without it. Attributing this view to the author of Politics (in Book Three $)^{81}$, he speaks firmly in favour of election, the 'nobler' manner of appointing rulers, characteristic of peoples governed by civilised laws, which ensures 'that the best prince can be had ${ }^{82}$. Paradoxically, this means that, thanks to election, God can suggest to the people even better candidates for offices than those $\mathrm{He}$ chooses for them Himself through succession.

Marsilius does not say, however, that only a government instituted through an election is legitimate. Not every people - and this applied even to the Romans at some point - is ready to elect its own government. Thus, alternative ways of instituting power are admissible, provided that this is done in due fashion.' Accordingly, a dynasty ruling the country uninterruptedly from the moment it was settled has a legitimate title to power, but so has the one that has won it in a just war or received it from its former rulers. The decisive condition is the consent given by the subjects. Consequently, Marsilius arrives at a conclusion which John Locke would repeat nearly four centuries later: the ultimate proof of the legitimacy of government is the fact that the subjects do not rebel against it.

However, while to Locke (a point to be discussed in Chapter Three) consent is a kind of equivalent of a social contract, to Marsilius it is a principle belonging to

81 Thus Marsilius in a sense 'democratises' Aristotle; see Strauss, 'Marsilius', p. 281; Andrzej Wójtowicz, Model władzy państwowej Marsyliusza z Padwy (Katowice: Wydawnictwa Uniwersytetu Śląskiego, 1977), p. 49. Sigmund also writes about other abuses of Aristotle's thought by Marsilius; cf. Sigmund Jr., 'The Influence, p. 397-398.

82 Cf. Marsilius of Padua, The Defender, Discourse I, Chapter IX, 7, p. 48. In Discourse I, Chapter XVI, Marsilius examines in detail the following question: 'Whether it is better for a polity to adopt a monarch by a new election each time, or to elect only one man together with his entire posterity, which is usually called hereditary succession'. In the conclusion of that chapter, he refutes an argument, characteristic of political theology, that a hereditary monarch is more similar to the prince of the universe, replying to it in terms of Aristotle's philosophy; cf. Marsilius of Padua, The Defender, Discourse I, Chapter XVI, 24, p. 113. 
the Aristotelian tradition of the legitimisation of power - a tradition justifying its legitimacy with the ruler's proper discharge of his function. The government is the more legitimate, 'the more it is over willing subjects and in accordance with a law passed for the common advantage of these subjects ${ }^{83}$. Out of the two principles legitimising representative power - namely, its origin by the will of the ruled and its concern for their common good - Marsilius considers each principle sufficient, but he does not consider the case of these two principles being opposed to each other. Accordingly, he does not take into consideration the situation of alienation of a government instituted through election, but neither does he consider the opposite situation, when an impostor's rule turns out to be beneficial to the populace and for that reason it wins the people's approval.

Despite its divine origins, this power does not fit into the scheme of the economy of salvation, either. It did not emerge in order to serve the salvation of the ruled, either collectively or individually; the aim of the state is merely to ensure a decent life for its citizens ${ }^{84}$. The laws governing that state refer to that aim; thus, they are not merely a complement to the laws of nature, which themselves direct man towards eternal happiness, as St. Thomas considered them to be ${ }^{85}$. The transcendental dimension of Marsilius' state is reduced to the fact that it helps the subjects to satisfy their need for the transcendental element in their lives; on the specifically spiritual human needs Marsilius writes almost in the form of an aside:

But beyond the things just mentioned, which meet the needs of this present life alone, there is something else which those who share a civil community need for the status of the world to come, promised to the human race through the supernatural revelation of God; and which is also useful for the status of this present life: sc. the worship and honouring of God, and the giving of thanks both for blessings received in this world and those to be received in the future world as well. And in order to teach these things and to guide men in them, it was necessary for the city to appoint certain teachers ${ }^{86}$.

83 Marsilius of Padua, The Defender, Discourse I, Chapter IX, 5, p. 47.

84 Naturally, Marsilius does not deny the spiritual dimension of human life; he only ascertains that philosophers have not said much here, because they could not prove its existence: 'And it being that philosophers as a whole could not convincingly demonstrate the second mode, sc. the sempiternal, nor was it among things that are self-evident, therefore they did not trouble themselves to pass on whatever might be in order to it'; cf. Marsilius of Padua, The Defender, Discourse I, Chapter IV, 3, p. 19.

85 Marsilius of Padua, The Defender, Discourse I, Chapter X, p. 51-55; Żyro sees in it the primacy of will over reason, characteristic of nominalism, which Thomists regarded as the source of laws; 'To Thomists, political power is a product of reason, to nominalists, a product of will'; see T. Żyro, Wola, p. 127.

86 Marsilius of Padua, The Defender, Discourse I, Chapter IV, 4, p. 20. 
This need not mean denying the authenticity of the spiritual need as such - even though the phrase about its being 'useful for the status of this present life' is degrading enough; what it means is subjecting it to the institution that satisfies it, i.e. secular state authorities. Salvation is contained here in the concept of a good, decent life; it is not the highest good, as in the thought of St. Thomas; it is not even, as in Dante's writings, a good equal to earthly happiness.

To St. Thomas, the transcendental goal of the state determines, inter alia, its form of government; this is precisely how he explains the superiority of monarchy over other forms of government. If, however, the state has no such dimension, then in choosing the form of government one can rely on natural reason alone. Aristotle's view concerning the best form of government is not unequivocal. Thus, in this particular case, Marsilius does not abuse his authority when he leaves the matter to the circumstances. For it may happen that the people are not yet mature enough to embrace the best form of government and must be content with another. Monarchy is superior to other forms of government in that 'this type of principate seems almost connatural to $\mathrm{us}^{87}$. Even though Marsilius' preference for one-person rule is obvious, he considers the question of the form of government to be secondary to the unity of the rulers. Following Aristotle, he presents a slightly modified classification of forms of government and states openly that the question of which of the 'tempered' forms of government is the best, and which of the 'flawed' is the worst, does not belong to the subject of his considerations. He does not want to speak on the 'the relative ranking of the rest [of the forms of government - A.W.] in terms of goodness or badness ${ }^{88}$ at all; it is for this reason, among others, that he is sometimes considered to be a forerunner of modern political thought.

On the other hand, Marsilius states most emphatically that there must be one government in the state, and that it must not be divided in any way, no matter whether it is exercised by one, a few or many ${ }^{89}$. There has to be only one source of law in it. If individual cities or parts of the country have their own authorities,

87 Marsilius of Padua, The Defender, Discourse I, Chapter IX, 4, p. 45.

88 Marsilius of Padua, The Defender, Discourse I, Chapter VIII, 4, p. 42.

89 Commentators on Marsilius' thought differ on whether this ruler is a king or an emperor, and whether, consequently, Marsilius advocates universalism within the Christian world; this problem need not be settled here, however. For what is important to Marsilius is only for the secular authority to be more universal than the spiritual authority. 
all of them needed to be subordinated to one and the same superior authority ${ }^{90}$. Any power belonging to a part comes from the superior authority;

no individual person, of whatever rank or status he may be, nor any collective body has any principate or coercive jurisdiction over anyone in this world unless that authority has been given to him or it directly by the divine or human legislator ${ }^{91}$.

Further on Marsilius argues extensively that the existence of various power centres means conflict between them and stirs up social unrest that may even lead to the collapse of the state ${ }^{92}$. The unity of power is a condition of the unity of the people, i.e. of a unity of order; to rise against the ruler is to attack that order.

However, Marsilius is far from seeing people as beings who by their very nature pose a threat to the social order and thus holding that the burden of maintaining the social order falls on the ruler. On the contrary, he assumes that each human is capable of lawmaking, i.e. of laying down coexistence rules that benefit the state, even though older individuals with experience in public activity are naturally more competent here ${ }^{93}$. By this he does not mean legislative competence, but only the authority that is necessary for the legislator. Despite this reservation, his belief concerning the people's lawmaking ability is important in that he has removed the divine law from the state (leaving it in the Church, naturally) and preserved only man-made laws.

Once again abusing Aristotle's authority, Marsilius claims that only the people may be the causative reason for law, i.e. the universal body of the citizens, or their 'prevailing multitude', which has already been mentioned and will be discussed further below. All the laws draw on its authority; in the state there may not be any other authority. Moreover, the laws made by the universal body of the citizens

90 On several occasions Marsilius, writing about an authority, attributes to it primarily judicial functions (for more on the subject see Wójtowicz, Model władzy, p. 75-76), which is connected with the problem of judging that very authority when it breaks the law. Marsilius is inclined to forgive the ruler his minor misdemeanours, as punishing him repeatedly would undermine the authority of the office itself. On the other hand, the commitment of a grave offence by the ruler requires his suspension in the exercise of his office and his subjection, as a subject, to the judgement of his temporary substitute or substitutes; this may not, however, Marsilius emphasises, result in a situation of diarchy; cf. Marsilius of Padua, The Defender, Discourse I, Chapter XVIII, p. 123-126.

91 Marsilius of Padua, The Defender, Discourse I, Chapter 17, 13, p. 122.

92 Marsilius of Padua, The Defender, Discourse I, Chapter 17, 5, p. 117-118.

93 Strauss notes, however, that Marsilius defends with much greater conviction the people's ability to choose their spiritual guides than their ability to choose their secular rulers; cf. Strauss, 'Marsilius', p. 281-282. 
or its 'prevailing multitude' will be the best possible ones, for no one consciously hurts oneself, and the citizens are most inclined to obey the law if they regard it as their own. Marsilius cites the classical arguments against the rule by the people - that the people lack the wisdom necessary for lawmaking, that the people are diverse and changeable, and that a few individuals may do better what many do - but he refutes them with 'manifest truths', which he finds in Aristotle's writings, namely that the majority should legitimise the form of government and that - allegedly - the whole is always more perfect than its part.

While Marsilius admits that the 'prevailing multitude' of citizens is not capable of lawmaking, he immediately states that every one of them may judge whether the laws made are just or not, or even 'judge whether there is anything in what has been proposed which seems to need being added or taken away'; thus the multitude can make good laws 'when it is joined with the more learned and experienced ${ }^{\prime 94}$. For the people are capable of learning, considering that every man instructed by others may arrive at the truth. Ultimately, the whole legislative procedure should look as follows: the more competent from among the people submit a draft law to a general assembly, the people make amendments, the text is redrafted and again submitted for approval to the universal body of the citizens, to its prevailing multitude or to individuals of their choice only, whereupon the law comes into force. Thanks to this procedure, the universal body of the citizens becomes the legislator, only to the extent proper to it and according to its ability ${ }^{95}$.

Thus, in Marsilius' theory there appears a modern view - even though it may equally well be regarded as a classical republican topos - clearly inconsistent with Aristotle's scheme, that the will of the ruled, rather than the qualifications of the rulers, decides about the legitimisation of power. And this is by no means a doctrine taken from the Defender of the Peace, reading between the lines, or a

94 Marsilius, The Defender, Discourse I, Chapter 13, 3, p. 75-76; Discourse I, Chapter 13, 7, p. 78-79.

95 Analysing Marsilius' idea of representation in the context of contemporary disputes on representation and civic activity, Cary J. Nederman argues that Marsilius is in fact a critic of representation understood as delegation of power to the above-mentioned 'prevailing multitude'; the task of that multitude is not making law, but discovering it, while enacting it requires the consent of the community as a whole; cf. Cary J. Nederman, 'Knowledge, Consent and the Critique of Political Representation in Marsiglio of Padua's Defensor Pacis', Political Studies 1991, Vol. 1(39) (1991), p. 19-35, in particular p. 22-24, 32-35. 
by-product of the considerations on the best form of government, but a clearly expounded principle of legitimate power.

For it is by this authority that a prince is made such in actuality, and not by his knowledge of the laws, prudence, or moral virtue, even if these are the qualities of the perfect prince. For it is a fact that many may have these qualities, who nonetheless, because they lack this authority, are yet not princes (unless perhaps in proximate potential). ${ }^{96}$

Importantly, the 'prevailing multitude' of the body of citizens must not be confused here with 'a few individuals', i.e. with aristocracy. 'The few individuals' have nothing in common with the 'multitude', i.e. with the people, because they do not come from among them. The rule by a few is a form of government completely different from the rule by many; meanwhile, the 'prevailing multitude' always appears in conceptual connection with the body of citizens ${ }^{97}$. Marsilius does not pay much attention to the matter, believing perhaps that it is difficult to overlook the difference between a group of individuals from outside the people exercising power over them and a group of people coming from among the people and exercising power in their name. At the institutional level, it is clear in any case; for the people's 'prevailing multitude' is appointed by the citizens themselves from among themselves.

I say 'prevailing part' taking into consideration both the quantity and the quality of persons in the community upon which the law is passed. This is so whether the said body of citizens or its prevailing part does this directly of itself, or commits the task to another or others who are not and cannot be the legislator in an unqualified sense but only in a certain respect and at a certain time and in accordance with the authority of the primary legislator. ${ }^{98}$

96 Marsilius of Padua, The Defender, Discourse I, Chapter 15, 1, p. 88.

97 On the question of whether the body of the citizens is the sovereign, or merely its 'prevailing part', Wójtowicz observes that Marsilius, while writing about the people, does not use concepts related to sovereignty (Wójtowicz, Model władzy, p. 48), but neither does he use this concept when writing about valentior pars. On the other hand, according to Strauss, 'Marsilius thus allows the sovereignty of the people to remain entirely dormant'; cf. Strauss, 'Marsilius', p. 283. Even Quentin Skinner, who on methodological grounds precludes any conceptual 'prolepsis' of that kind, writes: 'Already they [Marsilius and Bartolo de Sassoferrato - A. W.] are prepared to argue that sovereignty lies with the people, that they only delegate and never alienate it, and thus that no legitimate ruler can ever enjoy a higher status than that of an official appointed by, and capable of being dismissed by, his own subjects'; Quentin Skinner, The Foundations of Modern Political Thought (Cambridge: Cambridge University Press, 1978), I, p. 65. On how the expression 'valentior pars' has been interpreted in the course of history, see Wójtowicz, Model władzy, p. 61.

98 Marsilius of Padua, The Defender, Discourse I, Chapter 12, 3, p. 66-67. 
Marsilius does not write how that part, being a microcosm of the state, constitutes itself, contenting himself with an assertion that it 'should be identified from the honourable custom of polities or determined according to the opinion of Aristotle, Politics VI chapter $2^{99}$. What is important in any case is for the people to continue to govern themselves, while delegating their prevailing part.

What is evident from the description of the legislative procedure is, however, that the 'prevailing part' may come to absolutely dominate the body of the citizens. In the most egalitarian variant, law is made by members of the assembly distinguished by their competence, by no means a faction of the rich, and the body of citizens accepts it, possibly revising the draft law before enactment. In the most elite version, by contrast, the body of citizens elects from among itself a certain part that makes law, submits the draft to the citizens for consultation, but incorporates only selected proposed amendments and enacts the law in a form that the people might not approve, given the opportunity. This is a situation that Marsilius does not consider; meanwhile, it may occur precisely because the people ultimately act through their representatives. As in the case of representatives for the council, their raison dêtre is that, even though the approval of a law requires the authority of the people, the quality of that law requires qualifications that are attainable only by the few; thus the natural inequality between people is ultimately the justification for representation.

Irrespective of the relationship between the body of citizens and its prevailing part, there is no doubt that the institution of representation is used by Marsilius to form the government; here authorisation occurs in the classical form of authorisation of certain individuals or an individual to act on behalf of the people. It is the people who appoint the government, and the people who dismiss it and change its composition. The legislator is the 'primary cause' of all institutions in the state, but he acts through the government, which is, as

99 Cf. Marsilius of Padua, The Defender, Discourse I, Chapter 12, 4, p. 67-68. In the place indicated, Aristotle does not discuss the matter. The editor of Marsilius' work identifies the passage as line 1318a. Aristotle writes there: 'Since there are two classes out of which a state is composed - the poor and the rich - that is to be deemed law, on which both or the greater part of both agree; and if they disagree, that which is approved by the greater number, and by those who have the higher qualification. For example, suppose that there are ten rich and twenty poor, and some measure is approved by six of the rich and is disapproved by fifteen of the poor, and the remaining four of the rich join with the party of the poor, and the remaining five of the poor with that of the rich; in such a case the will of those whose qualifications, when both sides are added up, are the greatest, should prevail' (p. 130-131). 
Marsilius wrote, 'the secondary cause, in the sense of instrumental or executive ${ }^{100}$. The justification for instituting an executive authority is its effectiveness, but it is legitimised by the will of the legislator, of which it is an arm.

For when these individuals do something, the entire community does it: since those who exercise the function of prince do it in accordance with the determination (sc. legal) of the community ${ }^{101}$.

Marsilius locates this institution, too, in Aristotle's scheme, and the government corresponds to the human heart ${ }^{102}$.

$\mathrm{He}$ also counts the clergy, an estate peculiar in that its usefulness does not suggest itself as obvious, among the state's institutions and its constituent parts (such as its defensive force, judges, crafts and medical practice) necessary for its efficient functioning:

Nevertheless, all peoples have agreed on this, that it is appropriate to establish it for the worship and honour of God, and for the benefit consequent upon these practices for the status of the present world or of that to come. For many religions or followings promise reward for those who do good, and punishment for evildoers, to be meted out by God in a future world ${ }^{103}$.

Religion is therefore only one of the many institutions serving the preservation of the social order and the fulfilment of human needs. Pagan priests, Marsilius claims, while they did occupy themselves with the cult and teaching, most importantly also occupied themselves with the curbing of human passions.

In the case of the true religion, i.e. the Christian faith and Mosaic law, things are different; the priests are to prepare people for living in the future world. Marsilius extensively presents the beginning of the history of salvation and

100 Marsilius of Padua, The Defender, Chapter 15, 4, p. 90.

101 Marsilius of Padua, The Defender, Discourse I, Chapter 15, 4, p. 90.

102 Further on Marsilius presents individual state institutions established by the rulers, complementing a functional description with a list of virtues that must characterise a given institution. For this reason, Żyro writes about a 'naturalization of the state' in the thought of Marsilius, whom he regards as a forerunner of introducing purely natural metaphors into political theory: 'The state is no longer a reflection of the "mystical body" or a relationship between the mystical body and the political body, but it functions in imitation of an animal'; cf. Żyro, Wola, p. 168. However, one may equally well assume that Marsilius' metaphor corresponds to the traditional early mediaeval images of the state in the form of the human body.

103 Marsilius of Padua, The Defender, Discourse I, Chapter 5, 10, p. 28. 
Christ's sacrifice, but when he expounds the role that the clergy should play in that religion, he does not even mention that it was Christ who founded it.

Now certain individuals, called 'priests' and 'deacons' or 'levites', were instituted within communities as teachers of the law just mentioned and as ministers of the sacraments in accordance with it. Their office is to teach the commands and counsels of the evangelical Christian law in those things that must be believed, done or avoided with a view to the status of the world to come, i.e. to attain the status of blessedness and to avoid its opposite $^{104}$.

Marsilius immediately adds that there are other disciplines, too, by which man becomes well disposed to fulfil that task, but he fails to enumerate them, so as not to prolong his argument. Differentiating between the reasons for the existence of various occupations and their final causes, he closes his argument with a conclusion that the goal of priesthood is to preach the divine law and administer the sacraments in accordance with it; the justification of their function in the state, however, remains to ensure eternal happiness for the people. For the state, as has already been stated above, is designed to ensure not the people's eternal happiness, but merely a decent life. Fulfilling God's law is a part, but merely a part of that life; that is why, the clergy may not be elevated above the other estates. Denying to it a divine provenance, Marsilius covers it in its entirety with the logic of the Aristotelian organism; to Aristotle nothing other than political science is the 'master art'. Thus, what is more evident in Marsilius' state than the separation of secular and spiritual elements is their being entwined with each other ${ }^{105}$. This does not yet mean a subordination of spiritual power to secular power, as is the case in the Hobbesian Leviathan, but only a consistent deprivation of the spiritual authority of the decision-making power on any matters other than spiritual ones.

This is an extensive question, going far beyond the limits of the present chapter; it is, however, easy to summarise, for Marsilius' position may be

104 Marsilius of Padua, The Defender, Discourse I, Chapter VI, 7, p. 34-35.

105 Cf. Wójtowicz, Model władzy, p. 93-94: 'In the plan of the Defensor Pacis, it is Christian citizens who decide about the life of the State and religious life (however, only in so far as human interference is allowed in Christianity), it is on them that all the licit authorities on earth depend, and in this sense one may assume that to Marsilius the extents of the concepts of civitas vel regnum and ecclesia overlap with each other, as they become reduced to a civic community [...] This is true, however, only for the "communities of the faithful, once they have been perfected" (iam perfectae - II, 17, 9). In a situation where the legislator or the rulers were unbelievers, Marsilius saw the need for an abolition of that political and religious unity. 
reduced to several principles which he enumerates in the final part of his work ${ }^{106}$. The most important of them says that only secular authorities are allowed to use force. Because a kingdom is a Christian state, and there may be only one authority in the state, ecclesiastical administration must be subordinated to the secular authority. Thereby the bishops lose their right to use excommunication without the involvement of the secular ruler, as well as the power to pass verdicts convicting heretics, or to independently appoint priests for discharging administrative functions or administrating Church property: the secular ruler is indeed obliged to preserve the Church in the state of evangelical poverty. The great reformers of the 16th century, Luther and Calvin, would think similarly; it is just that they would want to reform the Church with the help of the state, while all Marsilius wants is to strengthen the state, so that it stands guard over earthly peace ${ }^{107}$; the arrangements he proposes do not aim at the salvation of the people of God.

Marsilius' thought may be a good illustration of Kierkegaard's opinion, invoked at the beginning of the present chapter, that the Middle Ages were permeated with the idea of representation, even though the mediaeval people did not fully realise it. Marsilius did not create a coherent idea of representation, but he did think about power in the state and in the Church in terms of representation. This may be most clearly seen when he considers the make-up of the ecclesiastical council, isolates the 'prevailing multitude' of the body of citizens, or discusses the appointment of a ruler who wields power under a mandate from the legislator. In opposition to mainstream medieval thought, Marsilius introduces the idea of bottom-up representation; the council represents the People of God, while the secular ruler represents the legislator-sovereign. But before whom do the council and the emperor represent those who have appointed them? The feudal monarch represents God on earth before his subjects; similarly, the pope represents Him before His confessors. Do, therefore, the highest spiritual and secular authorities represent the people before God?

It is not by accident that Marsilius' thought does not contain itself within such an elegant figure. Marsilius cannot turn God into an audience within this relation of representation, the third party within it, the one before whom it occurs, given

106 Cf. Marsilius of Padua, The Defender, Discourse III, Chapter 2, 1-42, p. 547-556.

107 The idea of a reform itself is so similar, however, that even Skinner, once again in defiance of his methodology, admits that Marsilius' arguments, 'anachronically speaking', lead to a 'Lutheran' vision of a division of power and spiritual and secular jurisdiction; cf. Skinner, The Foundations, I, p. 19. 
that God Himself is the original, distant cause of all power. Putting the people in God's place - which ignoring Him as the causa remota of all power would come down to - would put the people on an equal level with God. Marsilius does not go quite that far. This would only be accomplished by the French revolutionaries who would cut off the head of a king by the grace of God and thus would definitively remove the last authority legitimising itself with a source rival to the people. Marsilius' power has two sources, God's will and human will, and Marsilius consciously refrains from inquiring whether perhaps they are not occasionally in conflict with each other.

For in mediaeval realities, stressing the purely human origins of secular power would have put it in a situation of subordination in relation to spiritual power, the rise of which is written down in the Holy Scripture. If one is to be equal to the other, secular power must come from God to no lesser a degree than spiritual power. Marsilius could not have asserted that secular power came from the people and that even so the emperor stood above the pope, for even if spiritual power also came from the people, this would have been the case with the false pagan religions only. Three centuries later, Hobbes would go to great pains to convince his readers that Christian sects challenging the authority of the sovereign were also among such false religions. This would come all the more easily to him, however, because his era abounded with prophets preaching a religion of war; therefore, he could put their religious doctrines on a par with the pagan ones.

Ultimately, Marsilius thus assumes that each kind of power comes from God, but all the rulers, secular as well as religious, owe their office to the people $\mathrm{e}^{108}$ : the people of the republic or the People of God. (Incidentally, this assumption was not challenged later, either by Luther or by Calvin, who wanted to clearly separate the spiritual and temporal orders, for it turned out to be even more useful in a situation in which a secular authority was to reform the corrupt Church.) Thus, in the dispute between the religious and secular authorities, the idea of representation was used by Marsilius only partially. The emperor's secular power could not be completely bottom-up representation, as long as people believed that topdown representation might occur in the person of the pope.

108 Power comes from the people, but not as presented by Machiavelli, for whom power almost lay in the street to be picked up by anyone with enough courage and with fortune on his side. Power comes from election by the people and the people are like God in the act of election; to perceive Marsilius as Machiavelli's forerunner is a misunderstanding in this context. 


\section{Top-down representation - bottom-up representation: the two sources of legitimisation of secular power}

Aristotle's political theory, which was a point of reference for St. Thomas, Dante and Marsilius of Padua, makes it possible to address the matter of the legitimisation of power in the context of solicitude for the well-being of the community as a whole, but not in the context of its origins. According to Aristotle, before the emergence of the state with a specific form of government, that community does not even exist; consequently, it is not possible for it to give power into anyone's hands under an act of authorisation typical of representation. Moreover, handing over power would stand in absolute contradiction to Aristotle's idea of active citizenship, for the citizen is defined by the fact of personally exercising power in the polis, making laws in the assembly and delivering verdicts in court.

The problem of the origins and handing over of power will thus emerge in medieval thought in connection with spiritual power and its relationship to secular power. As Aristotle's ethical and political thought does not have any transcendental dimension whatsoever, its usefulness in the dispute concerning the superiority of one kind of power over the other is limited. For if one supports oneself with the Philosopher's authority, this dispute may be decided in favour of either party. If one recognises the superiority of spiritual goods over the earthly ones, then the kind of power that is conducive to acquiring them will be higher; it is only that Aristotle naturally does not envisage this kind of power in the polis. If, on the other hand, we assume that salvation is merely one human need among many, the kind of power which looks after the polity as a whole will stand higher; it is only that Aristotle does not consider such a need at all. An equilibrium of goods would speak in favour of an equilibrium between secular and spiritual power, but this solution, too, is contradictory to the Philosopher's thought, because he arranges goods to form a clear hierarchy. Consequently, a dispute on the relationship between these two kinds of power cannot find a conclusive solution in Aristotle's scheme; that is why, it has to unfold in the field of theology and, to a certain extent, of history, and involve the matter of representation, if only in the area of handing over spiritual power by God Himself.

In the theological dispute, the advocates of the superiority of the pope's power seem to have stronger arguments at their disposal. Their crowning argument will be the handing over of the keys to Peter and, subsequently, the apostolic succession, established by Christ Himself. What comes to the fore from among the historical events is the so-called Donation of Constantine; that it was a forgery would be proved only by the Italian humanist Lorenzo Valla in the mid-15th century. Moreover, the pope's authority and primacy over the emperor is to be justified by 
a centuries-old ecclesiastical tradition. The advocates of the emperor's primacy are therefore in a more difficult situation, as it is they who have to challenge longestablished beliefs. They need to prove that the handing over of the keys to Peter was not an act of authorisation, and thus Peter was not a representative of Christ on earth, and given that no apostle individually received power from Christ, all the successive popes have been mere usurpers. The emperor Constantine, in his turn, did not possess Rome in such a manner that he could give it over to the pope; he had no right to divide his power or his empire.

The conciliarists supporting the emperor could not invoke any event of as great symbolic significance as the handover of the keys, but they also derived their crowning argument from Holy Scripture: Acts shows the early Church as a community administered collectively by apostles; it even describes the first ecclesiastical council, i.e. the Jerusalem council. Thus, the conciliarists juxtapose bottom-up representation with top-down representation: it is not the pope who is the representative of God on earth, it is the council that represents the People of God awaiting Christ's second coming. The papacy is thus downgraded to a supporting institution to the council; it is not even its representative, but an agency that should handle the purely organisational aspect of Church life. It is the council, and only the council, that confers authority upon the pope. Here Aristotle's philosophy once again becomes useful in the dispute being considered: as part of the Church, the papal office may derive power exclusively from the ecclesiastical council, which represents the Church as a whole.

The idea of bottom-up representation, which had arisen in the internal Church dispute on the primacy of papal decrees over the resolutions of the council, paved the way for an analogous idea in secular power structures. Thus, according to Carl Schmitt, 'All significant concepts of the modern theory of the state are secularised theological concepts' ${ }^{109}$. One may identify in Marsilius' treatise the moment at which bottom-up representation was born, even though the whole process of the ideological foundations of the religious and secular authorities growing increasingly similar to each other was unfolding in a broader context. The logic of ecclesiastical power lent itself to the state and vice versa; ultimately, as Ernst Kantorowicz puts it, out of the mystical Body of Christ the mystical Body of the republic emerged ${ }^{110}$.

109 Carl Schmitt, Political Theology: Four Chapters on the Concept of Sovereignty, Translated and with an Introduction by George Schwab, With a New Foreword by Tracy B. Strong (Chicago: The University of Chicago Press, 2005), p. 36.

110 Cf. Kantorowicz, The King's Two Bodies, p. 192: 'Clearly, the mediaeval dichotomy of sacerdotium and regnum was superseded by the new dichotomy of the King and 
In the Middle Ages, however, this process encountered obvious limitations, as illustrated by the treaty discussed in the present chapter. Secular power legitimising itself by means of bottom-up representation could only coexist with a religious authority that would legitimise itself in a similar way. As bottom-up representation and top-down representation are not complementary $y^{111}$, but rivals, each kind of power legitimised through top-down representation precludes legitimisation by means of bottom-up representation: power either comes from God or from the people (as shown by the later bond between the Church and the ancien régime and its difficulties in adapting to a republican order). Faced with a hostile religious authority representing God on earth, the secular authority, representing merely the people, was fighting a losing battle, as long as the people believed that in the person of the bishop of Rome they had to do with a vicar of Christ. That is why, given the divine provenance of power in the Church, Marsilius repeats that all power, including secular power, comes from God, even if the authorities in which that power is vested are elected by the people. Only the revolutionary doctrine, in contrast to natural law theories, which passed over that question in silence, would announce that all power came from the people and none from God.

For this reason, the medieval idea of representation is entangled in characteristic paradoxes, proper to its bottom-up and top-down versions. For what does it mean that the pope represents God on earth before His people? Does it mean the he impersonates Him all the time until the Parousia, as if Christ had not departed to join His Father in Heaven, but remained in the person of St. Peter and his successors? Or perhaps that the spiritual authority is to fulfil God's will on earth, to rule the earth in God's place or to promote His interests, as if He Himself were unable to do it from the heights of Heaven? Even though in the context of the

the Law. In the Age of Jurisprudence the sovereign state achieved a hallowing of its essence independent of the Church, though parallel to it, and assumed the eternity of the Roman empire as the king became an "emperor within his own realm." But this hallowing of the status regis et regni, of state institutions and utilities, necessities and emergencies, would have remained incomplete had not that new state itself been equated with the Church also in its corporational aspect as a secular corpus mysticum.

111 These two kinds of power are complementary only provided that, in the state which was considered equitable in the Middle Ages, the power coming from divine anointment was exercised with the consent of the subjects also, pursuant to the Roman principle Quod omnes tangit, ab omnibus tractari et approbari debet (What touches all should be considered and approved by all); cf. Bernard Manin, The Principles of Representative Government (Cambridge: Cambridge University Press, 1997), p. 87-90. 
doctrine of God's omnipotence all these answers are absurd, of course, attempts have been made by a variety of political movements - which Voegelin describes as 'Gnostic' in his The New Science of Politics - to translate each of them into reality. The basic paradox of top-down representation, and indeed of any other kind of representation which seeks to legitimise itself through transcendence, lies in the fact that it is not that God needs a representative, but that the authority wants to legitimise itself by invoking its Principal. If it fails, i.e. if it proves unable to secure recognition from its subjects, it will remain a usurpation.

In the idea of bottom-up representation, as outlined in Marsilius' treaty, another paradox is inherent. While it is obvious whom the emperor represents, it is by no means obvious before whom he represents them. May he, as a ruler, represent his subjects before God, considering that he was given his power by Him? The presence of God in the life of a political community does not allow Him to be ignored in secular power relations, even if $\mathrm{He}$ is only a distant cause of that secular power. It is only by removing God beyond the realm of politics, as would happen in modern political theory, that a place would be vacated for the people and the nation as the exclusive principal that delegates power. It is then, however, that the paradox of bottom-up representation would be fully revealed. Before whom will the sovereign People now be represented? To whom will its representative be accountable? A pious king could still fear God's punishment for discharging his function badly, but what is it that the present-day representatives of the Nation might fear? In bottom-up representation, the idea ultimately sanctions the representative's power over the principal; the People, the source of power, turns into the people subject to the authority in which that power is vested $^{112}$.

112 Aleksander Hertz sees this paradox in the legitimisation of totalitarian power, but he is wrong in narrowing it down to this kind of power only; cf. Aleksander Hertz, 'Posłannictwo wodza' in: Szkice o totalitaryzmie (Warszawa: Wydawnictwo Naukowe PWN, 1994), p. 106-107. Actually, this paradox is inherent in the very concept of 'the people', which is a crucial theme of Margaret Canovan's book; see Margaret Canovan, The People (Cambridge: Polity Press, 2005). 



\section{Representation and sovereignty of power}

\section{Sovereign, or unlimited, power}

Jean Bodin, the author of Six Books of the Commonwealth, is perhaps the last of the great political thinkers ${ }^{113}$ to invoke the Aristotelian scheme and actually make use of it, as far as allowed by the goal he has set before himself. In going beyond that scheme, Bodin does not bend it and argue - unlike Marsilius and the other authors discussed in the preceding chapter - that he is still following Aristotle or deriving ideas from his writings that are not contradictory to his oeuvre. He does not continue to offer assurances of his respect for the Greek philosopher; rather, he points out his 'errors', i.e. those of his claims that are manifestly in conflict with his own vision of the state. Slightly simplifying the matter and defining it in terms anachronistic to both thinkers, one may say that Bodin takes over from Aristotle a general vision of society, but juxtaposes it with a different conception of a political system.

One may not claim, however, that Bodin combined Aristotelian organicism, taken over from the scholastic philosophy of the Middle Ages, with a modern doctrine of power. That doctrine is not modern, because, in his commonwealth, power, even though it derives from God, is not representative in character, just as in the estate-type kingdom, into which that power is integrated, there is no hierarchy of power. In order to strengthen that power, Bodin takes it out of society, as it were, seeking to keep society itself intact at the same time. That is precisely why, while he ignores the idea of 'top-down' representation being inherent in secular power, he at the same time confers upon it the attributes of sovereignty ${ }^{114}$; it has those attributes not because it derives from God, but in order to fulfil its function, i.e. to keep the state whole and stable.

Bodin's France is being torn asunder by powers different from those that used to tear apart the medieval monarchy, liable by its very nature to a politicotheological conflict of the kind discussed in the preceding chapter. Its governing doctrine is Gallicanism; consequently, there are no longer two compact and mutually dependent kinds of power, spiritual and secular. The French monarch's power is, however, very much weakened by the civil war between the Catholics

113 However, his status as a classic is disputable; he is ignored, e.g., by Strauss and Cropsey in their History of Political Philosophy quoted in the preceding chapter.

114 On the sources of Bodin's idea of sovereignty, see John Underwood Lewis, 'Jean Bodin's "Logic of Sovereignty", Political Studies, No. 16 (1968), p. 207. 
and the Protestants, and additionally restricted by the customary law which the estates of the kingdom tend to invoke. Thus, Bodin's objective is not to ideologically strengthen one kind of power at the expense of the other, but rather to find a justification for strengthening royal power - secular as much as spiritual - in some of its aspects, by liberating it from these limitations. This is precisely what Bodin, an influential jurist from the Politiques party, seeks to achieve by developing his doctrine of sovereignty.

This is not to say that that the politico-theological problem had been definitively resolved in Christian Europe. Henry VIII neutralised it only temporarily by creating an established Church; due to the Puritan movements, this dispute resurfaced during the second, truly influential wave of the Reformation in the British Isles. In the thought of Hobbes, who entered into a polemic with religious radicals, determined to turn green England into a New Jerusalem, there are no more arguments in favour of a divine provenance of secular power. It is not God that Hobbes' sovereign represents; it is not by His grace that he rules; all God does is command obedience to that authority, whatever its origins.

In place of God, who once became incarnate, revealed Himself to the people and left His vicar behind, Hobbes placed an Artificial Providence: a God that is mortal but equally benevolent. Even though he wields absolute power over the people, he ultimately rules by their grace, because they are his authors, i.e. his creators. But so that the origins of power do not suggest to the subjects any claims undermining the character of government, Hobbes must adopt an idea of representation that fully corresponds to the logic of sovereignty. For in the Hobbesian commonwealth the government is to fulfil functions of such a kind that any limitation whatsoever resulting from a different idea of representation would deprive it of the power necessary for that purpose.

Thus, even though the idea of representation figures prominently in the thought of Thomas Hobbes, it is not among the subjects that its interpretation focuses on. This is understandable in so far as it was John Locke who introduced the idea of representative government, while Hobbes' historical contribution is the creation of a new idea of sovereign power, one of the most important, if not the most important political institution of the modern era, in which all the threads of his theory come together. Representation is but one of them, even if a special one; for the contract between people, as a result of which they establish a commonwealth, is a contract of representation, even if it might with equal justification be described otherwise. Hobbes will use the idea of representation to justify the legitimacy of any existing government, for according to his theory no government may be anything but representative. This applies also to that 
government which was manifestly imposed forcibly, without any kind of covenant among the ruled.

Thus, the present chapter presents two strategies for strengthening power: the first one creates the idea of sovereignty in order to challenge the traditional representation of the estates of the kingdom, which weakens royal power, while the other creates an idea of representation that will allow the idea of sovereignty to be inferred from it, which will make that power entirely unlimited.

\section{Sovereign power against representation: Six Books of the Commonwealth by Jean Bodin}

Bodin defines sovereign power as power above which there is no other. This is absolute and perpetual power; it is not limited in its scope or in the period for which it is wielded. Even if it is handed over, it is not restricted by any terms ${ }^{115}$. Nothing can restrain the will of the sovereign; the sovereign is the only source of law, while he himself is not subject to it. The essence of his power is, therefore, that he makes law for others regardless of their consent in any form whatsoever ${ }^{116}$.

On the other hand it is the distinguishing mark of the sovereign that he cannot in any way be subject to the commands of another, for it is he who makes law for the subject, abrogates law already made, and amends obsolete law. No one who is subject either to the law or to some other person can do this. That is why it is laid down in the civil law that the prince is above the law, for the word law in Latin implies the command of him who is invested with sovereign power ${ }^{117}$.

115 Jean Bodin, Six Books of the Commonwealth. Abridged and translated by M. J. Tooley (Oxford: Basil Blackwell, 1967), Book I, Chapter VIII, p. 25-27. Thus, e.g., Roman dictators, within whom absolute power was vested, but for a limited time only, were not sovereigns.

116 Cf. Bodin, Six Books, Book I, Chapter VIII, p. 32; this second aspect is highlighted in particular by Preston King, who argues that the sovereign actually 'commands law'; cf. Preston King, The Ideology of Order. A Comparative Analysis of Jean Bodin and Thomas Hobbes (London: George Allen \& Unwin Ltd, 1974), p. 296-298. Bodin's thought is generally interpreted in that spirit, even though some commentators stress the fact that the author of Six Books on several occasions writes expressly about just rule, and see in those observations the idea of the consensus of the subjects. Lewis argues, e.g., that to Bodin it is the contents of law, rather than the person of the lawmaker, that is the ultimate source of obligations, and that sovereignty manifests itself to the fullest in the person of a wise monarch; cf. Lewis, 'Jean Bodin's, p. 217-219.

117 Bodin, Six Books, Book I, Chapter VIII, p. 28. 
However, despite Bodin's unequivocal declarations, this is not an unlimited and absolute power, given that the prince does not take upon himself the responsibility before God for his subjects breaking divine law when the ruler's command so demands. Bodin says this even more clearly than Aquinas (who reluctantly allows for the possibility of opposing a tyrant's will), even though civil disobedience will always be the ultimate form of disobedience to him; this applies in particular to magistrates, since they are the ruler's own appointees ${ }^{118}$. For the prince, set over his subjects by God, remains untouchable, even if he is evidently evil and tyrannical.

It is however permissible to fail to obey him in any commands contrary to the law of God and of nature, but one must then seek refuge in flight, go into hiding or suffer death rather than attempt anything against his life or his honour ${ }^{119}$.

However, the sovereign's compliance with the above-mentioned laws of God and of nature, which customarily limited the extent of his power in the Middle Ages, is not, crucially, subject to any kind of institutional supervision. Bodin is by no means willing to give the Church the right to admonish the king when he errs, and even less to impose an anathema upon him or to allow the subjects to disobey him. As the sovereign's power is God-given, no man may take it away from him, or judge whether the monarch's deeds are in compliance with the law of the King of kings. Whence can the subjects know, then, that the sovereign is not trespassing against the law of God and of nature? One cannot find any kind of answer to this question in Bodin's work; his commitment to the principles of tolerance seems to suggest, though, that, paradoxically, one has to seek it in one's own individual conscience, given that no social authority can decide on the matter.

Natural law poses even more problems for Bodin's concept of sovereignty, as it imposes limitations upon royal power, even though it does not do so directly. While therefore the king need not obey the laws and customs of the land he rules $^{120}$, he should respect the property law, because Bodin elevates it to the rank

118 Bodin analyses this problem in great detail, taking into consideration the character of the office. Cf. Bodin, Six Books, Book III, Chapter IV and V, p. 84-96. Not only in writing does Bodin allow such exceptions. As an ardent advocate of religious tolerance, he called for refusing the king the funding needed to establish religious unity; cf. John P. Plamenatz, Man and Society. Political and Social Theories from Machiavelli to Marx (a revised edition) (London - New York: Longman, 1992), I, p. 148.

119 Bodin, Six Books, Book II, Chapter IV and V, p. 68.

120 Cf. Bodin, Six Books, Book I, Chapter VIII, p. 31-33; Book I, Chapter X, p. 44-46. 
of a natural law. The sovereign is not allowed to deprive the subjects of their property, so he may not even arbitrarily levy taxes without the consent of the estates $^{121}$.

The limitations of the monarch's absolute power inherent in the laws of nature reach even further. While the sovereign is bound neither by the laws he has made nor by those enacted by his predecessors ${ }^{122}$, it is precisely the laws of nature that require him to honour covenants, in some cases even those contracted by his predecessors ${ }^{123}$. In addition to divine and natural laws, and in particular property rights, another limitation on the sovereign's power is leges imperii (constitutional or fundamental laws), safeguarding particular constitutional institutions and arrangements, such as the indivisibility of the state, the hereditary character of power and the transferability of power.

The constitutional laws of the realm, especially those that concern the king's estate being, like the salic law, annexed and united to the Crown, cannot be infringed by the prince. Should he do so, his successor can always annul any act prejudicial to the traditional form of the monarchy, since on this is founded and sustained his very claim to sovereign majesty ${ }^{124}$.

Why then, despite the clearly formulated limitations, does Bodin himself speak of the sovereign's absolute and unlimited power? He wanted to considerably strengthen the sovereign's power and at the same time preserve the kingdom's time-honoured institutions, not to demolish them; he illustrated his argument with an analysis of specific historical institutions, some of which did not serve to support his argument at all ${ }^{125}$. The limitations imposed by the law of God and the law of nature on 'unlimited' power are not a paradox: the sovereign's power is not in fact limited by any human will. One may not criticise Bodin's thought for lack of cohesion just because he believed it to be impossible for man to place man-made laws above divine laws. Believing power to come from God, considered to be the 'causa remota', he understandably held that the sovereign's power was limited by God's laws, and as natural law also came from God, he held that it, too, had to stand above man-made laws. The sovereign's power is absolute and unlimited only in the earthly dimension.

121 See Book I, Chapter VIII, p. 25-36.

122 Bodin, Six Books, Book I, Chapter VIII, p. 28.

123 Bodin, Six Books, Book I, Chapter VIII, p. 29-31, 34-36.

124 Bodin, Six Books, Book I, Chapter VIII, p. 31.

125 Cf. George H. Sabine, A History of Political Theory (Hinsdale, Ill.: Dryden Press, 1973), p. 381 . 
However, the matter indeed gets complicated in the case of leges imperii. For these are neither divine nor natural laws: they are political laws ${ }^{126}$. If the sovereign should respect them, it means he must be subject to man-made law passed by someone else. As these laws are binding upon any sovereign ruler, one may say that these are laws protecting the state itself against its ruler, in case he should wish to act to its detriment. This in turn allows one to think of the ruler as a person ruling a kingdom under a special mandate; sovereignty would now be vested in him, as in the democratic demos ${ }^{127}$. But the author of the Six Books does not even mention such a possibility; the sovereign's power comes from God, and not from the people, even if under the fundamental laws in some systems of government it is the subjects themselves who elect those wielding it.

Invoking its divine origins, Bodin does not define power in terms of representation, however, probably more or less for the same reasons as Marsilius of Padua, as discussed in the preceding chapter. The power received from God as a power to represent Him would make the ruler ideologically dependent on the institution which transfers it, i.e. on the Church. Thus Bodin's sovereign power is defined in a very narrow theological aspect, which in the era of religious fighting, when both camps have God on their banners, was not of any major importance: as God's representative, the king would not have any more of it. Nor would his power be strengthened were it defined in terms of 'bottom-up' representation, even though that kind of representation might be suggested by the superiority of the leges imperii over the law made by the sovereign.

In both cases, the author of the royal power, God or the people, would be the ultimate source of the power of the representative; thus, one may understand why Bodin 'neglects' this matter in particular. He does not persistently repeat that power comes from God, but neither does he insist that it does not come from the people. He pays much more attention to demonstrating that only succession in the male line, unlike all forms of election and inheritance in the female line, prevents unrest in the state. In doing that, he does not question the very idea of electing government, but only points to the harmful character of the procedure ${ }^{128}$.

126 King argues, however, that there is no clear distinction between natural and man-made law in Bodin's thought; cf. King, The Ideology, p. 138-139.

127 Cf. Sabine, A History, p. 381.

128 Nevertheless, the boundary between a private and public corporation is quite liquid; for more on the subject, see King, The Ideology, p. 83-84, 96-97, 117-120. 
Thus, Bodin practically ignores the matter of the source of power; in any case, he does not assume that it has a divine provenance, and this is the most important use that he makes of Aristotle's political thought. He cannot support himself with the authority of the Greek philosopher in justifying the unlimited character of power; what he can do is similarly legitimise it by invoking its function in the human community. For even though that community is bound by natural ties, it only becomes a state precisely, thanks to the government.

The state, or the commonwealth, as Bodin calls it, is a union of people living under a single government. However, these are not individuals but entire families with their 'chiefs', or the heads of the households, heading them. The state consists of families, and families in turn possibly make up bigger structures, which Bodin calls associations and corporations. Collegial bodies and courts belonging to the system of government also have the status of public corporations ${ }^{129}$, just like communes and whole provinces of the state, even if they are governed by their own laws and enjoy a certain degree of autonomy.

Similarly the commonwealth can include a number of communes and provinces which all have different customs. But so long as they are subject to the authority of a single sovereign, and the laws and ordinances made by it, they constitute a commonwealth ${ }^{130}$.

For it is of no consequence whether the above-mentioned commonwealth is big or small, as long as it is headed by a ruler who has no superior above him. The state is a common weal, a commonwealth, and it is so because its citizens, 'even if there is diversity of laws, language, customs, religion, and race ${ }^{131}$, even if they should have nothing else in common, have one lord above them, no matter how this has come about ${ }^{132}$. Bodin will have no small trouble in explaining this construction in the realities of the complex feudal relations, because this requires demonstrating that sovereignty and the relation of fealty are independent of each other. Aware that this view is far from obvious, he will argue that in the empire sovereign power does not belong to the emperor, but to the assembly of the estates. Ultimately, he will be forced to admit that there are in fact few rulers enjoying sovereign power, and consequently there are few commonwealths thus defined in Europe ${ }^{133}$.

129 Cf. Bodin, Six Books, Book III, Chapter VII, p. 96-107.

130 Bodin, Six Books, Book I, Chapter VI and VII, p. 20.

131 Bodin, Six Books, Book I, Chapter VI and VII, p. 20.

132 Bodin sees the origins of states in wars and conquests, even though he does not exclude the possibility of states arising through an agreement between heads of households; cf. Bodin, Six Books, Book I, Chapter VI and VII, p. 18-19.

133 Bodin, Six Books, Book I, Chapter IX, p. 36-40. 
Thus an organic state has a whole hierarchy of power, but only the sovereign's power is public; the other kinds of power are private, or 'personal'. It is only the sovereign's public power that creates a public sphere, as it does not arise naturally through private unions of families and their heads. In the public sphere, only the laws made by the sovereign are binding, for the heads of households only have the right to rule over that which is their own, i.e. within the borders of their property ${ }^{134}$. Emphasising that point, Bodin must also enter into a polemic with a widespread belief that this sphere is also constituted by customs; it cannot be so, for this would mean detracting from the sovereign's power. In the context of distinguishing between the private and public spheres, there is a characteristic difference between a monarchy and a tyranny; even though Bodin argues, in accordance with a mediaeval belief, that the former respects the laws of nature, while the latter tramples on them, it is another difference that seems more important here: namely that the king creates the public space by means of his laws, while the tyrant destroys it, extending his private rule to the state as a whole ${ }^{135}$.

Paradoxically, without sovereign power one cannot speak about citizenship, either, given that it is the public sphere that is the civic domain, even if - and that conceptual shift seems characteristic - Bodin defines the citizen's status directly in relation to government, omitting the institution of the public sphere. To him, the citizen is 'a free subject who is dependent on the sovereignty of another', which means that 'every citizen is a subject since his liberty is limited by the sovereign power to which he owes obedience ${ }^{\text {'136. }}$.

Defining the institution of citizenship in this manner demonstrates the whole ambiguity of Bodin's attitude towards the thought of Aristotle, to whom citizens are free agents in the public sphere. It is difficult to find a greater discrepancy between definitions. To Bodin, the public sphere is not a space for civic activity, but rather for citizens' subjection to the sovereign's power. Citizens' freedom

134 Bodin, Six Books, Book I, Chapter II-V, p. 6-9. Bodin realises, of course, that it is otherwise, and that the monarch's power over some of his mighty subjects is purely symbolic. Therefore, all he can do is argue that family relations should be subject to laws, just as heads of households are subject to sovereign princes. On the analogy between the household and the commonwealth cf. Book I, Chapter II-V, p. 6-9.

135 Bodin himself is close to that approach, writing: 'The one does that which he believes will further the common good, and the welfare of his subjects. The other consults only his own profit, vengeance, or pleasure, cf. Bodin, Six Books, Book II, Chapter IV and V, p. 62.

136 Bodin, Six Books, Book I, Chapter VI, p. 19. On the difference between the citizen and the burgher, cf. Bodin, Six Books, Book I, Chapter VI, p. 18-22. 
comes down to the fact that they are not subject to other people's private laws; the sovereign protects the subjects against that by introducing his own laws. Admittedly, depending on their estate they do share in the rights and privileges of a city-state'137, but not in making the laws of the commonwealth; in Bodin's opinion, Aristotle was quite simply wrong in believing it could be otherwise ${ }^{138}$. Thus, the political dimension of citizenship comes down to the fact that it is

the mutual obligation between subject and sovereign, by which, in return for the faith and obedience rendered to him, the sovereign must do justice and give counsel, assistance, encouragement, and protection to the subject ${ }^{139}$.

Moreover, it is out of the question for Aristotelian isonomia, or equality of citizens vis-ŕ-vis one another and before the law, to be binding in the public sphere. On the contrary, the public sphere is diversified by the rights and privileges bestowed on both entire estates and individuals. Actually, citizens are subject to different public laws. Bodin, aware how far removed he is here from Aristotle's normative philosophy, has no intention of explaining himself, however, because he deems it obvious that there has not been a state so far (or even the concept of a state) in which citizens would be equal in terms of their rights and prerogatives ${ }^{140}$. Crucially, in his own vision of a commonwealth, inequality before the law does not translate into a hierarchy of public power; it is not made up of differences in privileges, for any one of them may be taken away by the sovereign at any time.

Indeed, since citizenship does not involve exercising power, the form of government becomes a matter of secondary importance in this context $t^{141}$. Differences between various forms of government come down to the location of absolute power. Monarchy is the best form of government, not because the subjects enjoy the greatest freedoms in it, but only because it may be most efficiently administered. According to Bodin, Aristotle was simply wrong in praising mixed forms of government; such forms of government are not possible, given that either one person or an assembly may be the sovereign. Bodin is not consistent enough,

137 Bodin, Six Books, Book I, Chapter VI and VII, p. 20.

138 Cf. Bodin, Six Books, Book I, Chapter VI and VII, p. 20.

139 Bodin, Six Books, Book I, Chapter VI and VII, p. 21.

140 Cf. Bodin, Six Books, Book I, Chapter VI and VII, p. 22.

141 King claims, however - and that is the central idea of the section of his book devoted to Bodin - that this is precisely the French thinker's fundamental mistake. Absolute power may only be monarchic, for any form of collegial power involves observing certain rules binding upon the members of the ruling body, while the essence of absolutism is the absolute arbitrariness of the ruler; cf. King, The Ideology, p. 30, 249. 
however, to deny the name of 'state' to all those political bodies that are not headed by an absolute ruler; he only considers them to be ill-administered ${ }^{142}$.

Thus, Bodin ultimately goes even further than Marsilius in modifying Aristotle's scheme, but he does not do so in order to fit the idea of representation within it. He may be said to exclude it even more consistently than the author of Politics himself, in whose division between the true and perverted forms of government a semblance of the idea of representation appeared. Bodin sees in that criterion a possibility of criticising and weakening the government, and must therefore reject it. There are only three types of government, as distinct from tyrannical regimes: of one prince, several princes and of the people as a whole. The last is the worst, but anarchy, in which none obeys anyone else, is even worse ${ }^{143}$. He does not expect the state to improve its citizens; on this point, Bodin is getting close to Hobbes and ever further away from Aristotle. All they need the government for is to ensure that they live in order and harmony, as they are incapable of creating these conditions on their own. Showing considerable distrust towards all forms of popular government, Bodin will nonetheless not go as far as Hobbes, who demands that people surrender all their natural rights to the sovereign. Even if Bodin had such an intention, he could not express it in the terms in which he defines the relations between the rulers and the ruled.

By relating his theory to historical realities, Bodin must, willy-nilly, touch upon the question of representation; that is why in describing them he consistently neutralises the political importance of that institution. When he writes about officials, he treats them as executors of the sovereign's will, rather than as public figures occupying a certain position in the state administration. Naturally, he would wish for important offices to be held by subjects with high standing in the social hierarchy, but he would also be ready to appoint individuals of humble origins to them, if bringing the mighty under control were necessary in order to strengthen the commonwealth. For magistrates are the prince's armed forces, his living law, and their power is a deposit given to them by the sovereign ${ }^{144}$. They are representatives of the government, which is itself not representative. Describing it in the context of the complex feudal relations, Bodin points out that it is 'not the mere appointment of officials [which may be done by someone else - A.W.] that implies sovereign right, but the authorization and confirmation of such appointments' ${ }^{3}$.

142 Cf. Bodin, Six Books, Book II, Chapter I, p. 52-56.

143 Cf. Bodin, Six Books, Book VI, Chapter IV, p. 190.

144 Cf. Bodin, Six Books, Book III, Chapter IV and V, p. 91; Book I, Chapter X, p. 46.

145 Bodin, Six Books, Book I, Chapter X, p. 45. 
In this respect, too, the sovereign is bound by the laws of the kingdom. Detailed rules for appointing and dismissing officials, and the scope of freedom they are allowed, are proper to each particular form of government. All Bodin does is define the general rule the ruler should follow: permanent officials should not be allowed to command on their own, and if that is necessary, their power to command should be limited by the collegial character of a given office; those who enjoy much greater power may only exercise it for a limited period of time, no longer than several years. Holding power and offices, those individuals will not be particularly committed to the common good ${ }^{146}$. Even though the sovereign's power may actually rest only on them, Bodin shows a great deal of distrust towards officials, which is characteristic of sympathisers with absolutist rule.

It is therefore hardly surprising that Bodin barely mentions parliaments: institutions which, according to customary law, claimed the right to represent the subjects. If even a sovereign government does not represent God 'from the top down', there is no place in the commonwealth for any kind of 'bottom-up' representation; the parliaments' claims to levying taxes and granting tax exemptions are absolutely illegitimate: this task falls within the sovereign's exclusive competence, with parliaments merely giving their consent to the laws submitted by the king ${ }^{147}$. Characteristically, Bodin does not question the raison dętre of those bodies, but only deprives them of particular competences; he detracts from their power in so far as that would detract from the king's power. It is only when he writes about the system of government in France that he takes a principled stance, frontally attacking the parliaments' alleged powers:

There are those who say, and have published in writing, that the constitution of France is a mixture of the three pure types, the Parlement representing aristocracy, the EstatesGeneral democracy, and the King monarchy. But this is an opinion not only absurd but treasonable ${ }^{148}$.

For all estate bodies should be viewed as corporations, or civil communities. As they are not subject to the law of nature, the government will not respect their independence, as is the case with the family, which is a natural community ${ }^{149}$.

146 Cf. Bodin, Six Books, Book IV, Chapter IV, p. 128-132.

147 Cf. Bodin, Six Books, Book I, Chapter X, p. 47-48.

148 Bodin, Six Books, Book II, Chapter I, p. 54, cf. also Book III, Chapter I, p. 77.

149 King notes that 'Bodin's definition of the state does not even mention corporate bodies, quite apart from any implication that they are hierarchically superior to the family. He asserted that the state merely consisted in the (just) governance of several households through sovereign power. This implies no mediation by private corporations between the state and the family'; cf. King, The Ideology, p. 112. 
Upon the institution of sovereign power, all corporations and associations, which are made up of families and entire clans, exist in the civil sphere exclusively by the consent of those who exercise it. This is also the case with parliaments; they do not have any majesty in the presence of royal power ${ }^{150}$.

Depriving a representation of the estates of any real power, Bodin nonetheless clearly repeats after Aristotle that the state is based as much on power as it is on friendship,

which cannot endure unless fostered by associations, whether of estates, fraternities, corporate associations, or guilds. So to ask whether communities and corporate associations are necessary to the commonwealth, is to ask if the commonwealth can subsist without fellowship, which even the world itself cannot $\mathrm{do}^{151}$.

The king, too, the sole source of power, should be loved by his subjects and will be loved, Bodin argues, once he removes all causes for discontent from the commonwealth, leaving the exclusive power to his laws and ordinances ${ }^{152}$. Thus, the ideal of Bodin's commonwealth is harmony; nevertheless, the author of the Six Books has no doubt that it will not arise naturally, without an active and strong government. It is on that point that his organicist vision of society connects with the modern theory of sovereign power, though one not yet involving representative government.

Intending to strengthen the government without weakening society at the same time, Bodin brings his thought to a characteristic ambivalence. His theory falls between the classical and modern paradigms of politics, between the conception of Aristotle, who regards the state as a natural community, to which power also belongs, and the conception of Hobbes, to whom the state is an entirely artificial creation, which emerged, thanks to the government. In Bodin's theory, royal power is part of the kingdom, its central organ even, for it is royal power that turns a human community into a state, but at the same time that power is not restrained by any institutions, unless their existence is enshrined in natural

150 Cf. Bodin, Six Books, Book I, Chapter VIII, p. 31: 'At the same time the majesty of the prince is most fully manifested in the assembly of the three estates of the whole realm, humbly petitioning and supplicating him, without any power of commanding or determining, or any right to a deliberative voice. Only that which it pleases the prince to assent to or dissent from, to command or to forbid, has the force of law and is embodied in his edict or ordinance'.

151 Bodin, Six Books, Book III, Chapter VII, p. 105.

152 Cf. Bodin, Six Books, Book IV, Chapter IV, p. 128-132. 
law. Bodin halts power at the border of natural law; it is only Thomas Hobbes who will take one step further and subordinate natural law to power as well.

\section{Sovereign power, thanks to representation: Leviathan by Thomas Hobbes}

Hobbes addresses the subject of representation directly and discusses it exhaustively in one place only, in Chapter XVI of his Leviathan, entitled Persons, Authors and Things Personated, even though it keeps recurring throughout his fundamental work. Characteristically, there is no mention of representation in his treatise $D e$ Cive, published a few years earlier in Latin, which Hobbes himself considered the first work of a new political philosophy and which actually includes most ideas developed later in Leviathan. Equally characteristically, the theme of representation keeps recurring throughout Part Three of Hobbes' magnum opus, devoted to the 'Christian commonwealth', i.e. the Church, while it hardly occurs in Part Four, i.e. in his considerations on the 'kingdom of darkness', i.e. the Papist Church.

However, the representation discussed in this book is not the institution described by the author in the above-mentioned chapter, which is composed in the lucid and comprehensible manner so characteristic of him and modelled on the science of geometry. This special kind of representation may, at the most, be reconstructed on the basis of the text; its special character may only be seen when juxtaposed with the preceding conception, namely the author's considerations on the commonwealth. The crucial difference between them consists in the fact that one may speak of normal representation only within the limits of the law, whereas a state emerges precisely, thanks to original representation ${ }^{153}$. Thus it must be a unique, sui generis, relationship, significantly different from the former. It is only, thanks to that kind of representation, that the might arises that constructs the entire social world, the only world in which man can survive. Thus, it is not an accident that, as Sheldon Wolin notes, in the introduction to Leviathan Hobbes compares the creation of the public order to the creation of the world; to him, the words arbitrary and creative are synonyms ${ }^{154}$.

153 There are more such binary schemata in Hobbes' thought, e.g. the two kinds of violence that Giorgio Agamben writes about: violence before the introduction of law and violence within the limits of law, reserved for the sovereign; cf. Giorgio Agamben, Homo Sacer: Sovereign Power and Bare Life, trans. Daniel Heller-Roazen (Stanford, California: Stanford University Press, 1998), p. 17-20.

154 Cf. Sheldon Wolin, Politics and Vision. Continuity and Innovation in Western Political Thought (London: G. Alin \& Unwin, 1961), p. 248. 
To Hobbes, the first example of social behaviour in people - exceptional in the state of nature - will be a contract between them to stop the openly and tacitly ongoing war and to introduce the state of peace. The only way for this to happen is through the establishment of a sovereign government: a government not controlled by anybody, but capable of controlling everybody. The sovereign, who appears as a result of a compact among individuals, is their representative. This is not a compact, as Hobbes repeatedly emphasises, of a pre-existing community with a pretender to power, for in the state of nature there does not exist any kind of organised community: it will emerge only when the government constitutes it by binding it with law. People who are scattered about, waging open and partisan warfare against one another, do not even have any name in common except for a 'multitude'.

A multitude of men, are made One Person, when they are by one man, or one Person, Represented; so that it be done with the consent of every one of that Multitude in particular. For it is the Unity of the Representer, not the unity of the Represented, that maketh the Person One. And it is the Representer that beareth the Person, and but one Person: and Unity cannot be understood otherwise in Multitude ${ }^{155}$.

This description of the emergence of the state is obviously problematic. For how can an unorganised multitude create anything? How can all the people, or at least a significant majority of the populace in the state of nature, consider the same person, be it natural or artificial (an assembly), as their representative-sovereign, at the same time making a covenant with the others that it will be the same person?

Hobbes himself does not conceal this problem; on the contrary, he even exposes it for his own purposes, as the amorphous character of the state of nature only emphasises the importance of the sole order-maker in the world, i.e. the sovereign. Discussing the advantages and disadvantages of particular forms of government in his work De Cive, he draws a meaningful distinction between a multitude and a people ${ }^{156}$, which does not reappear in an equally clear form in Leviathan. It is detrimental, the author argues, particularly in a monarchy, to

155 Thomas Hobbes, Leviathan, or the Matter, Forme and Power of a Common-wealth Ecclesiastical and Civill (Cambridge: Cambridge University Press, 2003), Chapter XVI, 13, p. 114. In De Cive the Latin word 'multitudo' is rendered as 'a multitude', but in that work, which precedes Leviathan, Hobbes also emphasises that a multitude is not a natural unity; cf. Thomas Hobbes, De Cive, English Version, ed. H. Warrender (New York: Oxford University Press, 1987), p. 91.

156 Cf. Hobbes, De Cive, Part II, Chapter XII, VIII, p. 151. 
mistake these two concepts. For a people is a unity, one will in the state, irrespective of its system of government; it is the sovereign who wields the unity of will in the state. Consequently, and Hobbes is of course aware of this paradox, even in a monarchy the autocrat is the people. On the other hand, a multitude is always constituted by individuals subject to an authority, likewise regardless of the system of government. In the special case of democracy, the same people are both the people and the multitude: the people as the rulers and the multitude as the ruled. It is with distinctions of this kind that Hobbes wants to pacify the republican opposition to absolute power; the idea of the people loses all its political charm here. By definition, no people may revolt against its government, because the people is that government and may not be anything else:

But the People is not in being before the constitution of government, as not being any Person, but a multitude of single Persons; wherefore there could then no contract passe between the People and the Subject ${ }^{157}$,

and, by the same token, no contract between the people and the government.

While defending his theory against ideological criticisms, Hobbes nonetheless exposes it here to the charge of a lack of cohesion. If the representative-sovereign is elected by a multitude of human beings, but by each of them individually, the election of the same person, without prior consultations, borders on a miracle ${ }^{158}$. For in the state of nature all are absolutely equal and no choice suggests itself to one as an obvious thing to make. If Hobbes did not emphasise the individualism of the people living in that state, it could be assumed that the initiating contract was concluded by acclamation, but this possibility is precluded if only by the lack of a common language; how could it have emerged, given that linguistic communication requires observing some conventions, and the emergence of

157 Hobbes, De Cive, Part II, Chapter VII, VII, p. 110.

158 Hobbesian individualism, Michael Oakeshott argues, is so strong that there can be no appearance of a universal will. The representative, in a commonwealth already, makes the choice of each subject individually; his decisions do not take the will of some of the subjects into consideration more than that of some others, as it is not their will he acts upon, but his own. In this sense, each individual will is taken into consideration to the same degree; as regards the authorisation of the sovereign's decisions themselves, cf. Michael Oakeshott, Hobbes on Civil Association (Berkley - Los Angeles: University of California Press, 1975), p. 62. By contrast, Helmut Schelsky notes that from the fact that each subject makes a contract separately there follows each subject's individual responsibility; cf. Helmut Schelsky, Thomas Hobbes. Eine politische Lehre (Berlin: Dunker \& Humblot, 1981), p. 368. 
conventions presupposes some form of community ${ }^{159}$ ? This is an argument that Hobbes is unable to refute, but he need not do so, because - and this will be discussed below - his argument on the rise of government is fully subordinated to the legitimisation of power, rather than to the explanation of its origins. The philosopher is undoubtedly aware of this difficulty, and it is probably for that reason that his description of the creation of a commonwealth is extremely brief, though exhaustive enough to frighten all those who would be willing to risk leaving people even for a moment without subordinating them to some form of authority.

Other arguments showing non sequitur in Hobbes' reasoning prove the same thing: in the state of nature there is no place for the normal representation he had described earlier. Not only is a multitude unable to appoint one representative; it may not make any compact whatsoever, nor can anybody transfer his natural rights to anyone else, for each human is a natural person, but none is an 'artificial' person (according to Hobbes' terminology), meaning he has no legal capacity. In the state of nature, there is no law to regulate human relations - homo homini lupus est (a man is a wolf to another man), and natural laws are only wishful thinking, in foro interno; thus a multitude may not come forward in agreement in corpore. It is only the sovereign - an artificial God, but also an artificial human and the rules laid down by him that will confer legal capacity upon the people.

This is precisely where Hanna Pitkin sees 'Thomas Hobbes's problem', which may be summarised as follows: Hobbes was a great thinker, but his idea of representation is blatantly unilateral. While Pitkin takes into consideration the possibility that it was Hobbes' intention to mislead his readers and smuggle in an extra argument in support of loyalty to the sovereign within the idea of representation, she ultimately rejects it. In Pitkin's opinion, Hobbes wrote of representation with absolute sincerity; it is only that he completely overlooked a number of things. Pitkin writes: 'I suggest that Hobbes developed too narrow a perspective on representation by approaching it from only one angle, by taking into account only one kind of representing ${ }^{160}$. Consequently, the author presents other meanings of that term, in her opinion overlooked by Hobbes, in the successive chapters of her work.

159 On the problem of language in Hobbes' thought, see John W. Dangford, 'The Problem of Language in Hobbes's Political Science,' The Journal of Politics, Vol. 42, No. 1 (1980), p. 102-134, especially p. 121-125. Hobbes only addresses the problem of the arbitrariness of signs that do not have a 'natural' character and are a source of disputes in the state.

160 Cf. Pitkin, The Concept. 
Allegedly, his biggest mistake is to call the sovereign, too, a representative, whereas the idea of representation, as it is popularly understood, incorporates contents that the idea of sovereignty precludes. Firstly, the Hobbesian representative is not subject to any kind of control on the part of those whom he represents. Secondly, no one has authorised the sovereign to act as a representative: neither those who have elected him - for they are incapable of that because of their irrationality (a point that will be discussed below) - nor any other party: not an outside authority, for there is none in the state of nature. Thirdly, even if one assumes that it is because of the institution of representation that people emerge from the state of nature, this term must not be used to denote the relationship between the sovereign and his subjects where there is already a commonwealth: what we expect from a representative is not the same what we expect from a sovereign. Somewhat exaggeratedly, Pitkin secures herself against the argument that Hobbes simply understands that institution in a different way, noting that nowhere does he use phrases that might suggest a projecting character to his definition. Thus, the author ultimately, with a criticism characteristic of analytic philosophers, criticises what is the leitmotif of the work. Pitkin argues: 'But when we see the final result of the definition embodied in a Hobbesian political system with an absolute sovereign, we feel that something has gone wrong ${ }^{161}$.

However, it is Pitkin's conclusion, rather, that must make us wonder. For the opposite seems to be true and most of Leviathan's readers would be surprised if Hobbes had exempted this institution from the logic of absolute power. The peculiar nature of representation, which is the subject of contract concluded by people in the state of nature, consists in the fact that it is not in any way contradictory to sovereignty, as it is an aspect of it. Only the sovereign may be called a representative, for it is only in a state that he alone represents his subjects, even though not in such a manner as is the case under the rule of law, allowing each of the sovereign's subjects to enter into a relationship of representation with each other (excluding those who are incapable of that). This does not change the fact, however, that it is still unclear whom the sovereign actually represents. Is he indeed the representative of those who have elected him, considering that they actually could not have elected him?

Nonetheless, someone's will - and it was not the will of God - did determine the emergence of the state. Hobbes' critics, beginning with Hume, who attach the utmost importance to this issue, are right: it is impossible to prove that the 
commonwealth emerged from the state of nature by the will of people themselves by way of their voluntary covenant. However, they do not seem to realise that it is not Hobbes' intention at all to explain how states come into being, but rather to justify why the ruled owe obedience to the ruler. Regardless of how the state came into existence, whether by way of contract or by way of conquest (a sidetrack in Hobbes' thought), the ultimate argument justifying obedience vis-ŕvis the authority is the fear of its sword, even if Hobbes resorts to this argument only after attempts to persuade his readers that fulfilling the sovereign's orders in every case (or almost in every case, for the subjects do not owe their lives to the sovereign) is nothing more than doing him justice. They owe it to him, because they obliged themselves to do it, each one separately, in recognising him as their representative. He is their representative, because they remain in his power.

For one may argue that it is not an accident that Hobbes distinguishes two more kinds of representation which differ significantly from an ordinary contract of representation concluded between two people, namely the representation of inanimate objects (such as a hospital or a bridge) and the representation of children. What connects children and inanimate objects is that they lack legal capacity and thus appear in the public space, in which one may speak of a proper relationship of representation, exclusively thanks to their representatives: the administrator and parents, respectively. Looking at the social world from Hobbes' nominalist perspective, one may even say more; any supraindividual entities will appear in it only when they are represented by artificial, i.e. legal persons. Institutions in the sense of organisations do not exist in public life except through representation; just like children, they do not have a voice until someone speaks on their behalf. That is why, it is not enough for a representative of a hospital to be a natural person and to be able to speak; he must also have the right to speak in relevant situations.

Institutions (including the state), children and madmen share one particular characteristic: they are irrational. Irrationality is here something different from stupidity; it is the trait of creatures that are unable to look after their well-being on their own. They need representation for someone to act in their interest. They have no reason of their own, and so they have to rely on someone else's reason; they only have enough reason to understand that, and not all of them have even this ${ }^{162}$. Hobbes himself writes about this in the following way:

162 Pierre Manent argues as follows: 'Human reason, observing the absurdity of this war, is going to seek a means of peace. More precisely, what one calls reason is born from this necessity, which is experienced and recognized through passion: it is the faculty of inventing means or producing effects. The new political art will be the good use of 
Likewise Children, Fooles and Mad-men, that have no use of Reason, may be Personated by Guardians, or Curators; but can be no Authors (during that time) of any action done by them, longer then (when they shall recover the use of Reason) they shall judge the same reasonable. Yet during the Folly, he that hath right of governing them, may give the Authority to the Guardian. But this again has no place but in a State Civill, because before such estate, there is no Dominion of Persons ${ }^{163}$.

The last sentence tells us to distinguish between institutions and children and madmen as the object of representation. A hospital may only be represented in a state; it is only under national law and the charter of the hospital itself that either the manager or someone authorised by him or the hospital board is its representative. It might seem that the case is similar with children and madmen: it is only the law that may authorise someone to represent them. However, in a situation where the normal act of transfer of the right to represent cannot occur - and the state of nature is a situation of that kind - is it not obvious that the children will be represented by their parents? Hospitals do not exist in the state of nature, but children are born in it, and because they do not participate in the war of all against all, they must remain in someone's care, and thus in someone's power.

Considering this situation, Hobbes underlines that this subjection does not result from any natural ties, and even less is it determined by laws: as there are no binding laws in foro externo, they may not be enforced. Giving birth to a child does not give a woman the right to become its caregiver. She has that right exclusively because the newborn remains in her power, because she is the one who feeds it. Hobbes says it explicitly: if a mother abandons her child, it will be in the power of whoever keeps it alive. Thus, man enters into a relationship of power as early as at birth, and there is no isolated sphere in which he could hide from it.

For it [the child - A.W.] ought to obey him by whom it is preserved; because preservation of life being the end for which one man becomes subject to another, every man is supposed to promise obedience to him, in whose power it is to save, or destroy him ${ }^{164}$.

Incidentally, the author of Leviathan is so consistent here that he undermines the customary patriarchy in case the law should provide otherwise: if the father of

this faculty. What Hobbes clarified is the fact that men, if they want to be satisfied, are constrained to be intelligent'; Manent, Intellectual, p. 25.

163 Hobbes, Leviathan, Chapter XVI, 10, p. 113.

164 Hobbes, Leviathan, Chapter XX, 5, p. 140. According to Runciman and Brito Vieira, in a situation of this kind, it is necessary to introduce a fourth party to representation: 'the capable individuals who set up the trust in the first place'; cf. Runciman, Brito Vieira, Representation, p. 75-76. 
the child is in the power of its mother, as is the case in a royal family in which the woman is the ruler of the realm, it is she who also wields power over the child. In the state of nature, no one has power over anyone else, and yet the child remains within someone's power; in the state this power is limited by the law of the sovereign, being almost always transferred to the father ${ }^{165}$.

In the Hobbesian state of nature preceding the emergence of the state, there are of course no parents and children; there are only abstract individuals; there is no family, for there are no natural ties ${ }^{166}$. Even so, the father-children relationship plays a major role in Hobbes' thought in illustrating (but not in justifying) the extent of absolute power: it is precisely the same as the one that the paterfamilias has over his offspring, i.e. unlimited, unless, of course, the power of the sovereign himself limits the extent of his power later on. Just as the dominion of the parents over their children involves certain obligations vis-ŕ-vis their charges, political power, too, imposes on the sovereign particular obligations listed scrupulously by Hobbes, which are equivalent to a representative's responsibilities. The sovereign, Hobbes argues, should fulfil them in his own interest, just like the mother and father must raise their children in such a way as to prevent them from raising their hand against them. Even the greatest power will not be effective unless it undertakes educational activities; 'they [people - A. W.] ought to be informed, how great a fault it is, to speak evill of the Soveraign Representative' ${ }^{167}$. Just like children, the subjects have no rights to exact anything from the ruler, neither as the sovereign's obligations, nor as the representative's responsibilities.

The same may be said of 'fooles' and 'madmen', who are in the same situation as children. They are not guided by their reason; thus they do not understand the law and are incapable of respecting it. Unlike sane individuals, they do not understand it in foro interno, as rational rules of co-existence between people, which the former acknowledge, even if, driven by passions, they regularly break

165 Cf. Hobbes, Leviathan, Chapter XXII, 26, p. 162-163; Chapter XXX, 11, p. 235. Harvey C. Mansfield Jr. argues that precisely because the authority has no support at all in nature, it has to have an absolute character; cf. Harvey C. Mansfield Jr., 'Hobbes and the Science of Indirect Government', The American Political Science Review, Vol. 65, No. 1 (1971), p. 102.

166 In De Cive Hobbes writes about the union between a man and a woman in the absence of statutory law, but in such a way that it does not change the meaning of the metaphor of the state of nature; the absence of laws only emphasises the mother's rights to the infant; cf. Hobbes, De Cive, Part II, Chapter IX, 2-6, p. 122-124.

167 Hobbes, Leviathan, Chapter XXX, 9, p. 234. 
them. Therefore madmen, not unlike children, need an external force to replace the reason that they lack.

Over naturall fooles, children, or mad-men there is no Law, no more than over brute beasts; nor are they capable of the title of just, or unjust; because they had never power to make any covenant, or to understand the consequences thereof; and consequently never took upon them to authorise the actions of any Soveraign, as they must do that make to themselves a Common-wealth ${ }^{168}$.

Thus, madmen should be distinguished from sane individuals by the fact that they could not make a covenant to appoint a sovereign authority to make external law for them. But is it not precisely the problem of people in the state of nature, in which their passions so effectively obscure the light of reason that taking part in the war of all against all, they resemble madmen? Is madness a mental illness only, that a proportion of the population always suffers from, or perhaps rather a human affliction from which no one is completely free? Hobbes lists a whole catalogue of madness, and it is wide enough to include both pride and melancholy, dejection and various kinds of 'inspiration'. Ultimately, madness is nothing else but 'too much appearing Passion', similar to that caused by an excessive consumption of wine ${ }^{169}$. Will a sober man justify his actions before those who are drunk?

Thus the sovereign looks after his subjects' well-being, as the paterfamilias looks after his children's well-being, and a guardian after the well-being of the insane entrusted to him, without paying attention to what they themselves think about that. For the people whom he represents and over whom he rules are not any wiser than children or madmen; they are not guided by reason in the state of nature, and their innate instincts do not change while in the 'State Civill' ${ }^{170}$. These are peculiar children that will never grow up, and for this reason they actually resemble madmen more, or, even more precisely, mad children: children, because they may be represented without anyone's consent (authorisation); and madmen, for they will never come to their senses. The sovereign only changes the circumstances in which they live, but not the motives underlying their actions. They continue to be driven by fear, but no longer of other people, but of himself. All the sovereign has to do to make fear prevent his subjects from hurting one

168 Hobbes, Leviathan, Chapter XXVI, 12, p. 187.

169 Hobbes, Leviathan, Chapter VIII, 23, p. 55.

170 Piotr Nowak arrives at a similar conclusion via a different route, arguing that for Leviathan, the state machinery, citizens are nothing but 'ignorant, stupid "children"'; cf. Piotr Nowak, 'Posłowie' in: Carl Schmitt, Lewiatan, p. 175. 
another is to convince them of the inevitability of the punishment; if he has earlier applied himself to fulfilling his duty and instilled in them proper doctrines, they will have no doubt that the punishment is deserved ${ }^{171}$. Hobbes claims that it is outright

against his Duty, to let the people be ignorant, or mis-informed of the grounds, and reasons of those his essentiall Rights; because thereby men are easie to be seduced, and drawn to resist him, when the Commonwealth shall require their use and exercise ${ }^{172}$.

If he has neglected to do so, all that remains to him is the sword. Hobbes says so at the very beginning of his argument: 'Covenants, without the Sword, are but Words ${ }^{173}$.

Thus the recognition that the sovereign represents his subjects in the same way as the father represents his children explains why he has no authors, and why his power, though unlimited and not subject to any kind of control, is founded, even so, on the idea of representation. If, however, fear ensures obedience to the authority in extremis - ultimately the people will obey it, even if they consider it to be unjust - it may not be invoked as a justification for the relationship of representation. Quite the contrary, nobody would consider a ruler who systematically does him an actual or alleged injustice to be his representative. That is why the ruler-representative, as distinct from the ruler-sovereign, even though he is naturally one and the same person, will demand obedience, justifying it in the same way as the children's obedience to his father's will: he ultimately knows better what is good for them ${ }^{174}$. Paradoxically, one may say, therefore, that in the

171 From the considerations of Anabel Herzog, who uses the metaphor of the theatre to frame Hobbes' representation, it follows that the sovereign, in the absence of an audience, presents to the people their true nature and makes them aware of the necessity of absolute power; cf. A. Herzog, 'Hobbes and Corneille on Political Representation', The European Legacy, Vol. 14, No. 4 (July 2009), p. 379-389. On the other hand, Paul Dumouchel, also invoking this metaphor, stresses the difference between representation and representativeness and argues that representing-presenting his force to his subjects is among the duties of the sovereign, whose power is not at all representative to his subjects; cf. Paul Dumouchel, " "Persona": Reason and Representation in Hobbes's Political Philosophy', SubStance, Vol. 25, No. 2(80) (1996) (special issue: 'Politics on Stage'), p. 68-80.

172 Hobbes, Leviathan, Chapter XXX, 3, p. 231-232.

173 Hobbes, Leviathan, Chapter XVII, 2, p. 117.

174 That is why, in his polemic with the absolutist Robert Filmer, Locke will argue that according to common law, which is to him in fact the same as natural law, even the father's power over his female offspring is limited. 
thought of Hobbes, the first political philosopher of the modern era, the ancient ideal of wisdom giving a mandate to wield power perversely complements its legitimisation with the will of the ruled.

This is not, however, about some particular wisdom of the sovereign; what it comes down to is the ruler's understanding of one truly essential thing: how to guarantee security to the ruled. He does not know whether a given doctrine, be it religious, economic or aesthetic, is true or not; what he does know is whether it is subversive, whether it threatens the peace in his state or whether it poses no risk to it ${ }^{175}$. For as regards metaphysical doctrines, adults do not differ from children; because their reason is obscured by passions, they do not know and indeed cannot know how these doctrines affect social life, and it is precisely for that reason that they need to be treated in exactly the same way as children. What is equally important is that, as a natural person, the sovereign would be a man just like them and would not have that knowledge either. He only has it because it is in his interest, as a public person, to preserve power, and this is equivalent to maintaining peace, and that is why, as Wolin observes ${ }^{176}$, in Leviathan's commonwealth, there is ultimately no divergence between an individual will to survive and the sovereign's will to rule.

However, the paradox in Hobbes' thought lies in the fact that calling for obedience towards an authority regarded as unjust by the subjects, the author first and foremost appeals to the sense of justice and reminds us that pursuant to the commonwealth's founding covenant, each of the ruled is its author.

Because every Subject is by this Institution Author of all the Actions, and Judgements of the Soveraigne Instituted; it followes, that whatsoever he doth, it can be no injury to any of his Subjects; nor ought he to be by any of them accused of Injustice. For he that doth any thing by authority from another, doth therein no injury to him by whose authority he acteth $^{177}$.

175 However, Leo Strauss, who contrary to the entire tradition of the interpretation of Hobbes' thought emphasises its Aristotelian roots, sees a break with classical rationalism here; cf. Leo Strauss, The Political Philosophy of Hobbes: Its Basis and Its Genesis (Chicago: University of Chicago Press, 1996), p. 159-161.

176 Cf. Wolin, Politics, p. 279. Hobbes, as Wolin writes, significantly modified Sir Francis Bacon's motto, making use of a modern science (geometry). According to Bacon, 'knowledge is power', while according to Hobbes, 'knowledge is for the ruler'. Unlike Aristotle, Bodin and Montesquieu, to Hobbes political science remains indifferent to 'external', i.e. geographical, economic and cultural facts; cf. Sheldon Wolin, 'Hobbes and the Culture of Despotism' in: Thomas Hobbes and Political Theory, ed. Mary G. Dietz (Kansas: University Press of Kansas, 1990), p. 19-22.

177 Hobbes, Leviathan, Chapter XVIII, 6, p. 124. 
Thus, the one who complains against the sovereign complains against himself. This is where Pitkin rightly sees the biggest problem with accepting the Hobbesian idea of representation; the act of appointing a representative equipped with a sovereign's powers means not only that authority is granted to him, but also that it may not be withdrawn. In the very act of authorisation, the possibility of invoking the principles of justice that will be equally binding for the representative and the represented is precluded. What is more, only the sovereign will be able to invoke that act, recalling that his subjects have relinquished their natural rights. If a subject rises against the sovereign, he places himself outside the law; for the relationship between the representative and the represented, as eagerly reiterated by Hobbes, is not covered by the law of the land. Each disobedience vis-à-vis the ruler is a manifestation of enmity, which must provoke similar enmity, for it is not just about the sovereign meting out punishment for breaking his law in the subject's relations with other people.

For in denying subjection, he denyes such Punishment as by the Law hath been ordained; and therefore suffers as an enemy of the Commonwealth; that is, according to the will of the Representative. For the Punishments set down in the Law are to Subjects, not to Enemies; such as are they, that having been by their own act Subjects, deliberately revolting deny Soveraign Power $^{178}$.

Such individuals resemble madmen, and madmen are not covered by the laws of the state except through their representatives; in this case, their representative is the sovereign himself, and he is not subject to the law that he has made. Thus, what are the represented to do when the sovereign himself behaves like a madman and tramples on all principles of human co-existence? One cannot expect Hobbes to dwell on the subject; actually, he does not even touch upon it, but he writes a lot about the folly of the ruled, which will be discussed below.

While the act of authorisation imparts a unique character to original representation, one may try to present the rights of the sovereign representative vis-ŕ-vis the represented in terms of authority (discussed by Hobbes in Chapter $\mathrm{XVI}$ ), but a special kind of authority. The problem is that according to this conception, even the sovereign-actor must have his author. The actor has the 'authority', meaning the right to perform some act, 'and done by Authority, done by Commission, or Licence from him whose right it is ${ }^{179}$. Neither in the state of nature nor in the state of the commonwealth is there such an individual, however, given that everyone has placed all their rights in the hands of the ruler.

178 Hobbes, Leviathan, Chapter XXVIII, 13, p. 216.

179 Hobbes, Leviathan, Chapter XVI, 4, p. 112. 
Paradoxically, the sovereign will have a similar problem if he wants to appear in the role of the author himself, for, as repeatedly emphasised by Hobbes, the covenant is binding for the author, but not for the actor, as no law may be binding upon him. Thus, the unique status of the sovereign-representative does not allow him to enter into normal relations of representation, into which his subjects enter; all his relations with others are governed by that original one, which instituted him. Enjoying absolute power in the state, the sovereign is also 'absolute representation, and for this reason, he may neither relinquish the representation of part of his subjects nor limit it in any way; what he may do is grant some of his rights to a limited extent to various 'public servants'. Resembling 'the Nerves, and Tendons that move the severall limbs of a body naturall ${ }^{180}$, these servants have no legal power of their own. They do not even have their own will, as fulfilling the will of the sovereign is their sole raison dętre.

That is why, corporations are a case of representation that is much more interesting and proper to the idea expounded in Chapter XVI of the Leviathan. Hobbes compares them to smaller states within the borders of a larger state. Considering the risks they might bring with them, he writes with a characteristic vividness that in excess they are like wormes in the entrayles of a naturall man $^{\prime 181}$. Some of them even have a political or potentially political character; the limits of their 'power', i.e. the extent of matters in which individuals belonging to them act as representatives and beyond which they remain private individuals, are nevertheless always determined by the sovereign by his 'writt' or 'patent' A body politique that is to advise the sovereign is a special instance of such a corporation; it is this body, Hobbes admits, that is most often erroneously regarded as another kind of 'representation', i.e. as representation appointed by the subjects to appear on their behalf before the ruler.

For the sovereign may himself order his subjects from cities and other parts of his territory, to send their 'deputies' to him to inform him on the condition of the state and to consider, together with him, matters submitted by him. Thus, this is not a customary representation of a given land, because it owes its raison dętre solely to the sovereign. None of its resolutions has any decision-making power. Even if a council of this kind does represent all the subjects resident in

180 Hobbes, Leviathan, Chapter XXIII, 3, p. 167.

181 Hobbes, Leviathan, Chapter XXIX, 21, p. 230. Oakeshott observes that it was not so much freedom that was removed from Hobbes' state, but rather various 'superfluous' sources of power and authority and civil associations, such as Churches, which could be a source of unrest; cf. Oakeshott, Hobbes, p. 63.

182 Cf. Hobbes, Leviathan, Chapter XXII, 1-10, p. 155-157. 
a given territory, it does not have their power: that power remains vested in the sovereign, who, as the author, established it. Therefore, representation of that kind is nothing more than certain information, but not capacity for action. If the ruler does not need information of that kind, he will not convene a body like that at all.

For if they were the absolute Representative of the people, then were it the Soveraign Assembly; and so there would be two Soveraign Assemblies, or two Soveraigns, over the same people; which cannot consist with their Peace. And therefore where there is once a Soveraignty, there can be no absolute Representation of the people, but by it. And for the limits of how farre such a Body shall represent the Whole People, they are set forth in the Writing by which they were sent for. For the People cannot choose their Deputies to other intent, than is in the Writing directed to them from their Soveraign expressed ${ }^{183}$.

Since representation of that kind arises, so to say, by the grace of the sovereign, Hobbes does not have problems with it of the kind that Bodin has. In the system of government, it is merely a consultative body that may always be recalled. For Hobbes' presentation of the sovereign as a representative of the subjects precludes any other kind of representation, in which someone else is the author. In a commonwealth only the sovereign may be the author, for only the sovereign has the power, while his representatives, as his servants, may only use the power delegated by him temporarily and on his terms. And this is the truth that the subjects must understand: there is no representation independent of a sovereign authority.

Hobbes does not hesitate to call those who do not understand that madmen. It seems to those people that they speak the language of God and that they have been sent to the earth as His representatives. Invoking His name, they begin to criticise the authority, either cynically or because they have taken leave of their senses. The sovereign will defend his subjects against these people, false prophets who promise God's peace on earth and bring war; that is what he is their representative for. This also applies to those trouble-makers who, stupefied by ancient doctrines at universities, have put the People in the place of God. The Bible teaches us that a good tree cannot bear bad fruit, and a bad tree cannot bear good fruit. Such people bring nothing that is good, and therefore they cannot come from $\operatorname{God}^{184}$. Man owes the greatest good on earth to the sovereign: without him the life of man is 'solitary, poore, nasty, brutish and short' ${ }^{385}$; he is therefore truly

183 Hobbes, Leviathan, Chapter XXII, 25, p. 162.

184 Cf. Manent, Intellectual History, p. 34.

185 Hobbes, Leviathan, Chapter XIII, 9, p. 89. 
a man of God. Thus, the age-old problem of the sword and the crosier finds a systemic solution in Leviathan: the sovereign wields both the former and the latter. The unity of civic association, of the body political, is achieved precisely because, owing to joint representation, the state and the Church are one.

But the Church, if it be one person, is the same thing with a Common-wealth of Christians; called a Common-wealth, because it consisteth of men united in one in the person, their Soveraign; and a Church because it consisteth in Christian men, united in one Christian Soveraign ${ }^{186}$.

In Part III of Leviathan, which is rarely read nowadays, Hobbes argues that one may think about the Church in the same way as one thinks about the commonwealth ${ }^{187}$. This means that one cannot think about it at all without the person of a representative, and that the dimension of power is equally fundamental to it as it is to the commonwealth. For the Church is united not in God, but in the person of the sovereign, 'at whose command they [its members - A. W.] ought to assemble, and without whose authority they ought not to assemble ${ }^{3188}$. As there are many Christian states, there are also many Churches. If the whole of Christendom were one state, it would also be one Church. The pope's claim to the role of the vicar of Christ is therefore completely groundless. It would not be so if the Saviour had granted him the power to command, judge and punish, but as the pope has not acquired it, he remains an impostor. And until Christ's second

186 Hobbes, Leviathan, Chapter XXXIII, 24, p. 268. Elsewhere Hobbes writes with equal openness: 'How then can wee be obliged to obey any Minister of Christ, if he should command us to doe any thing contrary to the Command of the King, or other Soveraign Representant of the Common-wealth, whereof we are members, and by whom we look to be protected? It is therefore manifest, that Christ hath not left to his Ministers in this world, unlesse they be also endued with Civill Authority, any authority to Command other men'; Hobbes, Leviathan, Chapter XLII, 10, p. 343.

187 James Farr writes that Hobbes interpreted the Bible in such a way as to render it consistent with 'peace and the truth'. Farr identifies several interpretative strategies employed by Hobbes: 1. Deny nothing outright; 2. Put Scripture at the end, let it have the last word; 3 . Divide the passages into three sorts: the plain, the metaphorical, and the obscure; 4 . Conquer each with different strategies; 5 . Surrender all matters of interpretation to the sovereign; cf. James Farr, 'Atomes of Scripture: Hobbes and the Politics of Biblical Interpretation' in: Thomas Hobbes and Political Theory, ed. Mary G. Dietz, p. 184-185. Generally, according to Farr, Hobbes believes that his rationalism finds confirmation in the Bible; characteristically, however, he does not undertake to interpret Revelation; cf. Farr, 'Atomes of Scripture', p. 178, 181.

188 Hobbes, Leviathan, Part III, Chapter XXXIX, 4, p. 321. 
coming, Hobbes argues, there will be no other power over people except for the sovereign state authority ${ }^{189}$.

Thus Hobbes consistently reduces the religious dimension of human life to the institutional dimension of the Church. God's Kingdom is not and will not be on earth. The Catholic Church, the mystical Body of Christ, is admittedly one, but it is not one person; it will not become one person until the end of time ${ }^{190}$. Thus Christ does not have His priest-representative on earth. Hobbes says this explicitly: 'The Kingdome of God is a Civill Kingdome'191. God the Father was indeed represented on earth by Moses, by His Son and by the apostles, who were granted the power of the Holy Spirit; He is also one in three persons, each of whom represents one and the same God. The point is, however, that the kingdom of Christ is not of this world,

therefore neither can his Ministers (unlesse they be Kings,) require obedience in his name. For if the Supreme King, have not his Regall Power in this world; by what authority can obedience be required to his Officers? ${ }^{192}$.

Thus, the apostolic succession does not justify any spiritual power on earth.

Moreover, even if Moses gave laws to his people, all Christ left to his followers were recommendations ${ }^{193}$; he taught them how to live to achieve eternal happiness, but this is not the object of the earthly state. He did not teach them how to organise a state; all he did was call for respecting natural law, i.e. obeying the rulers. Christ could not even bestow laws, because, strictly speaking, law is 'the word of him, that by right hath command over others' ${ }^{194}$, and He, indicating the image of the Roman emperor on a coin, outright confirmed his title to exercise power on earth.

What is an ardent Christian to do, however, when the laws made by the sovereign make it impossible for him to comply with these recommendations? In a manner characteristic of him, Hobbes will answer that these recommendations only have the status of private beliefs, which may be professed in foro interno.

189 Cf. Hobbes, Leviathan, Chapter XLII, 124, p. 397; Chapter XLIV, 4, p. 419. Strauss observes that in his Elements of Philosophy, De Cive and Leviathan, however, Hobbes recognises various persons and institutions to be the supreme religious authority: the Church, Christ and the teachers designated by the sovereign, respectively; cf. Strauss, The Political Philosophy, p. 71-72.

190 Cf. Hobbes, De Cive, Part III, Chapter 17, 22, p. 236-237.

191 Cf. Hobbes, Leviathan, Chapter XXXV, 13, p. 284.

192 Hobbes, Leviathan, Chapter XLII, 6, p. 341.

193 Cf. Hobbes, De Cive, Chapter III, 17, 11-14, p. 227-231.

194 Hobbes, Leviathan, Chapter XV, 41, p. 111. 
A law-abiding citizen does not offend God; it is his sovereign who takes upon himself the guilt for issuing wrong laws. What remains to the subject is to believe in Christ and obey those laws, for they are certainly more reliable than private revelations. Hobbes makes an exception here only for those who saw Christ's resurrection with their own eyes; all others only give testimony to the fact that they have been told about that event in one way or another.

All the terminology and symbolism of state power, however, seem to alleviate the conflict between a temporal and eternal authority; for the sovereign himself is a god, even if a mortal one, and Providence, even if an artificial one. That is why, ever since the publication of Hobbes' work, its title has been a great mystery; Leviathan is a biblical monster from the Book of Job, after all, and not at all a benefactor of humankind. Why, then, did Hobbes choose that title? The word itself, mentioned only thrice in the text, has very negative connotations, but the famous figure on the cover does not resemble a monster at all. Carl Schmitt believed that 'the utilization of the image of the leviathan by Hobbes can be attributed to a "half-ironic literary idea born out of a fine sense of English humour"'195, but most interpretations seek something meaningful behind it. Two highly regarded commentators on Hobbes do not contribute much here, but neither do they emphasise the contradiction signalled above. Strauss actually repeats what Hobbes himself says: only a state is able to hold back the children of pride, and it is precisely pride that is the basic cause of feuds among people: Leviathan is their king ${ }^{196}$. Why, however, does the benefactor of humankind bear a monster's name, even though he is meant to suppress that pride? This is a question that Strauss does not ask, while Schmitt openly admits that he has failed to resolve the mystery of the book's title ${ }^{197}$.

This makes the recent attempt at solving that puzzle, undertaken by Noel Malcom ${ }^{198}$, all the more interesting. His argument is based on the assumption that Hobbes interpreted the figure of the biblical monster differently from mainstream biblical commentators. Through the agency of Marin Mersenne, who played a key role in the intellectual evolution of the English philosopher in the

195 Cf. Schmitt, Leviathan, p. 29 (Chapter 2, Note 13).

196 Strauss, The Political Philosophy, p. 13.

197 A review of three interpretations of Leviathan, entitled 'Die vollendete Reformation', published by Carl Schmitt in Der Staat (Vol. 4, No. 1, p. 51-69), included in the Polish translation of Schmitt's book; cf. Carl Schmitt, Lewiatan w teorii państwa prawa Hobbesa, trans. Mateusz Falkowski (Warszawa: Prószyński i S-ka, 2008), p. 148.

198 Cf. Noel Malcom, 'The Name and Nature of Leviathan: Political Symbolism and Biblical Exegesis,' Intellectual History Review, No. 17(1) (2007). 
years 1640-1648 (until his death), Hobbes gained access to the as yet unpublished book, Jacques Boulduc's commentary on The Book of Job. Boulduc elaborated on an idea that was already known in exegetical literature, systematically expounded by the Spanish Jesuit Juan de Pineda: the figure of Leviathan should be regarded as a creature first densely covered in smaller creatures, and later actually made up of them, just as the sovereign in the famous frontispiece engraving of Hobbes' work is made up of people. The interpretation is based on a linguistic argument: the Hebrew 'lwh' means 'to join'; 'lawrh' means 'has joined'. Therefore, one may see Leviathan as the head of a body made up of people who have decided to serve the ruler. Accepting such an explanation must ultimately lead to redefining the word itself: the sea creature will no longer be a symbol of evil, but a prefiguration of Christ himself.

Even though Malcom's argument is that Hobbes could have been referring to this interpretation, this does not explain why he did so without mentioning it, knowing that this was not a popular interpretation. Could he possibly believe that Boulduc's book, which had not otherwise made any major impact on Biblical exegesis, could change something? This would be a rather risky assumption. Thus perhaps Hobbes did not expect that, but as he knew the work still in manuscript form, he could not quote from it, or, if only for ethical reasons, present the monster metaphor included in it in his own work before the public became acquainted with it from Boulduc's book. The solution to the mystery could be as simple as that; it will satisfy a biographer of the author of Leviathan, but disappoint a historian of ideas. For if Hobbes wanted to use his book to bring about a revolution in the understanding of the term, then why did he choose a term whose meaning was so obscure?

One must be extremely careful in attributing mistakes to authors of Hobbes' stature. The question one should be asking is, rather, why he made this particular choice, and not why he made an unfortunate choice. Admittedly, in a sense, his strategy has been successful. For one may suppose that Hobbes wanted to introduce a completely new notion of Leviathan; that is why he does not even mention The Book of Job in his work, even though he quotes amply from the Bible, especially in the third and fourth parts of the book. In other words, Hobbes wanted the name of Leviathan to be associated exclusively with the commonwealth and with his work, rather than with the sea monster and the Bible. He wanted Leviathan to function exclusively as a metaphor even more meaningful than the other two, that of a mortal God and of artificial Providence, a metaphor expressing the paradoxes of sovereign authority: its unlimited character, but also its finality and beneficence, and its origin in the will of the people, otherwise hostile to one another. What does, then, this most famous third metaphor express? 
Does it only express a unity made up of a multitude, of which Hobbes himself writes, or perhaps something else, of which he does not write, but of which the metaphor itself reminds us?

The full title of the work itself tells us a great deal: Leviathan, or the Matter, Forme and Power of a Common-wealth Ecclesiastical and Civill. Leviathan combines in itself the matter, form and power. While, according to Schmitt, Leviathan is not a state, but the ruler of a state ${ }^{199}$, its rector or governor, Hobbes uses the term in both senses. In the Introduction, he writes about the 'great LEVIATHAN, called a COMMON-WEALTH'; in Chapter XVII, where he presents the emergence of the state, he also calls it LEVIATHAN; in the conclusion of Chapter XXVIII, dealing with punishments and rewards, he calls the ruler by that name while recalling his mortality ${ }^{200}$. That 'inconsistency' seems intentional; for the state, as has been said, exists exclusively, thanks to the ruler. There is no commonwealth without power, just as in the state of nature, which is natural to mankind, there is no power without a state. Thus, power is a form for the mass of humanity without which it does not even have a name.

It is in fact monstrous in its formlessness: irrational, unpredictable and destructive. Hobbes literally says that life in the state of nature is 'brutish', but also 'poore' and 'nasty'. Leviathan lives in the depths of the sea; it is not even able to enjoy the sun. People are precisely like that: monstrous, unless an authority takes in hand, or forms, their natural instincts. They acquire refinement, thanks to form, which is illustrated by the engraving of Leviathan, showing the figure of a man with noble features and a resolute stare, provoking fear first, but later trust as well, once one has noticed that he does not threaten the lives of the townspeople, but is in fact ready to defend them. As all other descriptions of the commonwealth-sovereign have an element of divinity in them, even if it is a peculiar, mortal divinity, one may suppose that Hobbes wanted the reader not to forget the human-animal dimension of the commonwealth. Giorgio Agamben claims:

Sovereignty thus presents itself as an incorporation of the state of nature in society, or, if one prefers, as a state of indistinction between nature and culture, between violence and law, and this very indistinction constitutes specifically sovereign violence ${ }^{201}$.

199 Schmitt regards him as a combination of God, man, an animal and a machine; cf. Schmitt, Leviathan, p. 19-20.

200 On pages 120 (Chapter XVII) and 221 (Chapter XXVIII), respectively; emphasis by Hobbes.

201 Agamben, Homo Sacer, p. 27. 
The capacity to enter into a covenant that results in the emergence of an artificial man is a peculiarly human characteristic; Hobbes seems to be using here the ambivalence of the Aristotelian definition of man as a political being, the only creature needing a state, but also one capable of moral improvement, thanks to the state. It is only people that can 'transfer the right ${ }^{202}$ : the animals do not understand what it is about, because they lack speech, which makes it impossible for them to make a promise. Paradoxically, God, who appears as an authorising witness here, also needs people to declare that He has accepted the covenants that they have made between themselves. Thus, the sovereign may not be anyone other than a man, and moreover an artificial man only, for as a natural man he would have retained the animal nature of his subjects. The biblical monster may be precisely an illustration of that paradox; it features in the Bible, and thus, given the authority of the Bible, it must be something real, but at the same time no one has seen it (one must not forget the Hobbesian scepticism); thus, Leviathan is present in it only as a concept, rather than a bodily being. This makes it all the easier for Hobbes to use it as a metaphor for the commonwealth and its power.

The name illustrates one more paradox: the benevolent character of despotism. Aristotle, who according to Hobbes had a destructive influence on minds, taught that tyranny is the worst form of government, so bad indeed that he even hesitates as to whether to call it a form of government at all. Meanwhile, Hobbes argues that tyranny is the only possible form of government, or even something more basic than a form of government: that it is a 'political culture ${ }^{203}$, to which all institutional arrangements must be subordinated. Only a culture of that kind, regulating human behaviour exclusively in foro externo, is suited to his evil nature; a sense of justice in foro interno is so weak that it must ultimately be replaced by fear. Thus, representation would be a form of taking control of the matter, enclosing it within a certain shape and making use of its potential powers, which in the state of nature neutralise one another. One might say that people, like magnetic fields, either repulse or attract one another; in the state of nature their charges neutralise each other, which is why in corpore they remain powerless, while in the commonwealth these charges get ordered by the

202 Cf. Hobbes, Leviathan, Chapter XIV, 21, p. 97.

203 This is Sheldon Wolin's description. In Wolin's opinion, this is precisely what the 'Hobbesian revolution' was all about: he removed the negative connotations of despotism by introducing the radically new concepts of 'commonwealth' and 'body politic'; cf. Wolin, 'Hobbes', p. 23. 
authority, which gives them great power to act; this is what is illustrated by the famous engraving from Leviathan ${ }^{204}$.

The sovereign does not, however, represent people, meaning rational individuals endowed with the will to act; behind the metaphor of representation of children and madmen there hide irrational creatures endowed with a survival instinct. Thus, the system of government itself is not particularly important to Hobbes. All the commonwealth is to guarantee to people living within its borders is physical safety; the monarchy is merely better equipped to do that than other forms of government. Nor is it important whether this kind of authority is representative of the community in the sense that it reflects its diversity; it is a representative government in the sense that it represents the will to survive shared by all; it stands for security. Such an understanding of representation certainly differs from contemporary popular and formal definitions ${ }^{205}$, but, as Wolin notes, power in Hobbes' commonwealth, instituted thanks to a covenant made by word, has the right to define words, i.e. laws and obligations ${ }^{206}$. As for Hobbes, he allowed himself arbitrarily to define Leviathan.

204 Cf. Manent, Intellectual History, p. 30: 'It is no longer an almighty being who gives existence and the meaning of existence to absolute power. On the contrary, it is powerless beings who create Leviathan to remedy their weakness. Absolute power is no longer God's representative, but mankind's; its transcendence no longer has its origins in God's strength but in man's weakness' Mansfield notes that the sovereign is therefore not an intermediary between people and God, but between the people in the role of the author and the people in the role of the subjects; cf. Mansfield, Hobbes, p. 110. Sheldon Wolin points to yet another aspect of that relationship: the sovereign "could not "represent" a community for there was none to represent except at the most elemental level of fear and insecurity. And because the Hobbesian community had surrendered its unity, unity must now be located with the unified will of the sovereign. Western political theory had to await Rousseau who undertook to join what Hobbes had carefully separated: Rousseau revived the older notion of community as a corporate fellowship and then endowed it with the unity of will associated with the Hobbesian sovereign; community and public will were one'; Wolin, Politics, p. 277.

205 Helmut Schelsky writes in the context of Hobbes's thought also of representation of ideas; God is one of those ideas; cf. Schelsky, Thomas Hobbes, p. 364.

206 Cf. Wolin, Politics, p. 259. In her excellent study devoted to the 17th-century English political thought, Nina Gładziuk writes that the Hobbesian sovereign, the lexarch, is supposed to guarantee to his subjects not only physical but also semantic safety, i.e. to define standards binding upon all and thus prevent a confrontation of contrary private opinions; cf. Nina Gładziuk, Druga Babel. Antynomie siedemnastowiecznej angielskiej myśli politycznej (Warszawa: Instytut Studiów Politycznych PAN, 2005), p. 284. 
However, can Leviathan's power be regarded as political? Can one describe with that term the relation of representation in which the sovereign and his subjects remain vis-ŕ-vis one another? Admittedly, to Hobbes politics is the art of building a political order (this metaphor comes from him), but it is the sovereign, rather than those who have elected him, that created that order. The order emerges 'from the top down', rather than 'from the bottom up', through representation of all major interests. Sovereignty need not be contrary to that idea of representation, if we accept, after Schmitt, that it is an attribute of an authority only in extremis, manifested in a situation and state of emergency. Consequently, one may say that in such a situation the representation of whatever people differ by gets suspended (this problem will be discussed in the final chapter of the book), and in its place there appears a representation of that which brings them together, i.e. the will to survive. The problem is, however, that, as Bernard Crick rightly claims, 'Hobbes's Leviathan saw government as a perpetual state of emergency ${ }^{207}$.

Thus the sovereign does not pursue politics, nor can he be accused of the biopolitics that Giorgio Agamben writes about, who sees in the body of the sovereign in the frontispiece 'the absolute capacity of the subjects' bodies to be killed ${ }^{208}$. Actually, what the sovereign has before himself is bare life, which he admittedly may destroy with impunity, but which according to Hobbes he should also protect, as it is his own body, his own matter. In the conclusion of the chapter concerning the sovereign's duties, Hobbes writes that:

207 Bernard Crick, In Defence of Politics (London, Reading and Fakenham: Penguin Books, a Revised Pelican Edition, 1964), p. 28. For this very reason, as the author argues further on, and with which we cannot fully agree, 'not merely the concept of "sovereignty of the people" is un- or even anti-political, but also the whole doctrine of sovereignty', p. 61; it questions social diversity or subordinates politics to itself, reducing it to a friend-or-enemy relationship.

208 Agamben, Homo sacer, p. 74. On the other hand, however, as Gładziuk writes, 'the Hobbesian state is plagued by a perpetual threat of rebellion, which any subject may stir up in the name of natural law. Paradoxically, however, there can be no rebellion against the Hobbesian commonwealth in the name of natural law. For to Hobbes the only natural law is equity of a procedural type, ordering the establishment of a commonwealth by way of covenant, and subsequently subjecting oneself to its laws. To rebel in the name of natural law against a commonwealth thus instituted would be completely pointless. For it would be an absurd rebellion against the only possible form of enforcement of that law on earth'; Gładziuk, Druga Babel, p. 286. 
every Soveraign hath the same Right, in procuring the safety of his People, that any particular man can have, in procuring his own safety ${ }^{209}$.

Even though the sovereign remains in the state of nature vis-à-vis his subjects, he would have to be as irrational as they are to kill for the same reasons for which they kill each other in that state, and this contradicts the Hobbesian idea of sovereignty. Consequently, one may say that the sovereignty of the ruler lays the groundwork for pursuing politics through 'bottom-up' representation, even though the person of the sovereign himself may pose a threat to it if he succumbs to those weaknesses of human nature from which he was meant to defend his subjects.

That is why, the Leviathan will provoke ambivalent feelings. As Michel Foucault writes on the subject:

That enormous artificial man who made all the right-thinking men of the law and philosophers tremble so, that enormous silhouette in the frontispiece to Leviathan, which represents the king with his sword raised and with crosier in his other hand, was basically a right-thinking man. And that is basically why even the philosophers who were so critical of him really loved him, and why even the most timorous are enchanted by his cynicism ${ }^{210}$.

Foucault surely exaggerates; Hobbes certainly did not succeed in persuading all and sundry to accept Leviathan. It is Schmitt, rather, who is right: the name Leviathan has overshadowed the message of the work itself, and has not become synonymous with a benevolent, but rather with a hostile state $e^{211}$.

The concept of representation, in which there is no place for the author of the representative - neither for God vis-ŕ-vis the king, nor for the people vis-ŕ-vis the parliament - could not find any kind of application outside the absolutist political system, in which the authority is an artificial Providence and a mortal God, brought into existence by the fear of a sudden death. From the perspective of other goals that the ruled will put before them, beginning with the protection of property, the concept itself will be a threat to them. Locke's Second Treatise of

209 Hobbes, Leviathan, Chapter XXX, 30, p. 244.

210 Michel Foucault, 'Five, 4 February 1976, Answer to a question on anti-Semitism. Hobbes on war and sovereignty. - The discourse on the Conquest in England: royalists, parliamentarians, and Levellers. - The binary schema and political historicism. - What Hobbes wanted to eliminate' in: Michel Foucault, Society Must Be Defended, Lectures at the College de France, 1975-76, trans. David Macey; eds. Mauro Bertani, Alessandro Fontana, François Ewald, Arnold Davidson (New York: Picador, 2003), p. 98.

211 Cf. Schmitt, Leviathan, p. 81. 
Government does not even include a polemic with the Hobbesian concept of representation, even if the author most resolutely opposes almost everything that determines the sovereign character of power in Leviathan. One may presume that Locke did not consider it necessary because, unlike Robert Filmer's paternalistic absolutism, Hobbes' theory had never become a living idea in English society. The history of England, as noted by Carl Schmitt, who evidently had a feeling that he was living in a historical situation similar to that in which Hobbes himself lived, unfolded against the expectations of the author of Leviathan; none of Albion's crowned rulers has resembled the figure in Leviathan's frontispiece ${ }^{212}$.

\section{Representation: sovereign rule over the author}

Jean Bodin and Thomas Hobbes set themselves the same goal, i.e. to strengthen political power, and wanted to achieve it by invoking the idea of sovereignty. Their principal works were written under similar circumstances of a more or less open civil war; even so, the several decades separating them make up a whole epoch, as it were, in the history of political thought. While Bodin wants to liberate the authority from its still traditional limitations - the mediaeval privileges of the estates and their assemblies - Hobbes defends the authority chiefly against radical religious reformers, who would like to subordinate the state to eschatological goals and achieve them, with its assistance, here on earth. One may say that Bodin's and Hobbes' concepts of sovereignty differ so widely precisely because they emerged in opposition to different doctrines. For this reason, when juxtaposing them, one should resist the temptation to take them out of that context, and should not interpret Bodin's conception as an incomplete version of Hobbes', or Hobbes' conception as an elaboration of Bodin's conception. Because the idea of sovereignty is central to both doctrines, historians of political thought seem to forget this very often, and even if they acknowledge Bodin's contribution, they

212 Cf. Schmitt, Leviathan, p. 80. This is not to say, of course, that Schmitt deprecates Hobbes' thought itself for that reason. On the contrary, in the last sentences of the book devoted to the thinker, he writes that to us he is 'the true teacher of a great political experience; lonely as every pioneer; misunderstood as is everyone whose political thought does not gain acceptance among his own people; unrewarded, as one who opened a gate through which others marched on; and yet in the immortal community of the great scholars of the ages, "a sole retriever of an ancient prudence." Across the centuries we reach out to him: Non iam frustra doces, Thomas Hobbes! [Thomas Hobbes, now you do not teach in vain!]'; Schmitt, Leviathan, p. 86. 
argue, like a 19th-century author, that Hobbes' concept of sovereignty is 'more complete and perfect ${ }^{213}$ than that of Bodin.

Without questioning the widespread opinion that Hobbes' doctrine is more coherent and expounded with an admirable clarity, it is worth noting how Hobbes achieved that coherence and why Bodin did not succeed in doing so. The author of the Six Books of the Commonwealth wanted to locate absolute power in Aristotle's scheme, which is absolutely unfit for the purpose; as a result, the absolutist political system designed by Bodin remained outside rather than within the institutions of a society regarded by him as an organism. Hobbes rejected that scheme, because he rejected the entire philosophical system of the Greek philosopher, from his vision of man all the way to his vision of the universe.

Moreover, in doing this, Bodin manipulated Aristotelian concepts in such a way as to fit his vision of the state into the realities of the feudal world, while Hobbes proposed a completely new language of description without worrying whether it was adequate to the existing political institutions. Thus, Hobbes made his theory coherent by making it completely projecting in character. The vision of a relationship between people is here wholly subordinated to power relations, something that the philosopher's numerous critics seem to fail to understand, accusing him of proposing a naive, atomistic conception of society. The image of colliding individuals in his work is a mere metaphor, an argument to justify absolute power, the only force capable of keeping people in the state of peace and cooperation.

Without denying Hobbes his genius, or the originality of his thought, one still may say, exaggerating slightly, that this originality was forced by the historical realities themselves, just as they made Bodin cling to the classical political theory. As noted by William Archibald Dunning, even though Bodin was familiar with the contractual theories of power, he could not invoke them, as they were the ideological weapon of the opposition ${ }^{214}$. As he by no means intended to revolutionise the state, but only to strengthen its authority without undermining the structure of society, his Aristotelianism may be considered to be as much a burden of tradition as a conscious choice ${ }^{215}$. While Hobbes was writing Leviathan abroad, in his own state, an open religious war was going on

213 Cf. William A. Dunning, 'Jean Bodin on Sovereignty. With Some Reference to the Doctrine of Thomas Hobbes', Political Science Quaterly, Vol. 11, No. 1 (1896), p. 103.

214 Cf. Dunning, 'Jean Bodin on Sovereignty', p. 90.

215 That is why, John Plamenatz regards him as a forerunner of conservatism, thinking about society in a way that is similar to Burke's; cf. Plamenatz, Man and Society, I, p. 166. 
and it could not remind anyone of a living organism; what it could bring to mind was, rather, a disintegrating universe. Thus, Hobbes makes a revolution in the word' with a sense that he is destroying nothing, because public life as a whole is in ruins already; his country, in which there are two rival power centres, is de facto in the state of nature. Thus if in Bodin's doctrine it is the rights and privileges of corporations, i.e. corporate persons making up the fabric of society, that are the backdrop for the rights of the rulers, in Hobbes' doctrine these are the natural rights of abstract individuals that only under the supervision of an authority will be able to create some forms of social life.

In an era of religious wars Hobbes could not argue - even if he believed so or considered this to be a 'noble lie', to which the philosophers claim they have the right - that power was God-given; for such a belief is the most important cause of unrest in the state, being bandied around by the inspired opponents of the existing political order. Thus Hobbes' originality consisted not in presenting the origins of power in an act of contract and transferring the prerogatives into the hands of a chosen person (institution) ${ }^{216}$, but in the acknowledgment that it came from the people. All his daring notwithstanding, however, Hobbes does not say that power does not come from God, even though in his doctrine legitimising power God is actually a 'superfluous hypothesis'. In any case, Hobbes' doctrine openly precludes the conception of 'top-down' representation, though not so spectacularly as 'bottom-up' representation, which serves republican troublemakers as an ideological weapon.

The strength of Hobbes' doctrine lies in the fact that with one concept he extremely elegantly legitimises the sovereign's authority, at the same time pacifying any opposition from all those who invoke the classical ideas of representation. To the republican advocates of 'bottom-up' representation, Hobbes may reply with his characteristic irony that power actually has its origins in the will of the ruled, i.e. in the universal will to survive, while to the religious advocates of 'top-down' representation he will say that it is also similar to divine power, given that it is not limited by the will of any human being.

And this is where the paradox of the idea of representation subordinated to sovereignty lies: it requires that the representative possess full power over the represented, if he is to prove equal to the obligation he takes upon himself in

216 This originality is denied to Hobbes by Quentin Skinner, who, in accordance with his methodology, reduces his idea to a polemic with the writers arguing in support of the Parliament; cf. Quentin Skinner, 'Hobbes on Representation,' European Journal of Philosophy, No. 13 (2) (2005), p. 155-184. 
that role ${ }^{217}$. Even though this must arouse understandable protests, Hobbes stubbornly repeats that people in the state of nature, resembling beasts rather than gods, had to create government in the image of God and beast, symbolised by the figure of Leviathan. Such is each sovereign authority, even if it was democratically elected and invokes the rule of law principle. The sovereign's rule is a rule above the law. 'Sovereign is he who decides on the exception', claims Carl Schmitt, and goes on to explain that the concept of sovereignty

must therefore be associated with a borderline case and not with routine. Because a general norm, as represented by an ordinary legal prescription, can never encompass a total exception, the decision that a real exception exists cannot therefore be entirely derived from this norm ${ }^{218}$.

This may only be done by an individual or a group of individuals, the actual sovereign not hidden behind any institution, and he must make that decision outside the law. And even though Hobbes, in Schmitt's opinion, made a mile-long step towards de-personalising politics and imparting a 'mechanical' character to $\mathrm{it}^{219}$, he correctly identified this particular principle.

Even though Hobbes' political thought certainly does not fit into the formula of decisionism, Schmitt did not go as far as to grossly oversimplify it, however, and expressed the said paradox as follows. It is precisely because, and only because, the sovereign's power is representative that he may suspend all the institutions of representation; even though it has no other legitimisation, the one it does have is sufficient. For Hobbes' entire argument - as coherent as his involvement in the historical context allows - is meant to prove that the relation of representation is prior to any law governing relations between the citizens themselves and between them and the authority. The sovereign had become their representative even before they became citizens; thus, he may annul any law, if the maintenance of order within the state, i.e. the maintenance of his rule, should so require.

An imposition of a state of emergency may be compared here to turning back history, to returning to the moment in which people, living in the state of nature, had already appointed a sovereign by way of contract, but he had not yet issued any law giving part of their natural rights back to his subjects. It is precisely in a

217 That is precisely why Steven Runciman and Mónica Brito Vieira believe that a relationship of that kind may not, after all, be defined in 'author-representative' terms; cf. Runciman, Brito Vieira, Representation, p. 143.

218 Schmitt, Political Theology, p. 5-6.

219 Cf. Schmitt, Political Theology, p. 50-52; this is also expressed, according to Schmitt, by the complex structure of Leviathan discussed above. 
state of emergency that it becomes obvious that regardless of the system of government in the state, the sovereign's law is his arbitrary command, and the sovereign is the one standing above the law. This conclusion may naturally be worded in more cautious terms, but this is what it actually means.

Schmitt's decisionism only captures the institutional aspect of the paradox of representation proper to sovereign power, however. Schmitt explains the raison d'état behind the sovereign's decision, while he does not explain at all why that rationale will be understandable to citizens; the legal positivism doctrine allows him to treat the raison détat as the ultimate rationale. Meanwhile Hobbes, regarded as a forerunner of this legal school ${ }^{220}$, also cites individual arguments behind obedience to sovereign power, and it is from them that he deduces the raison détat. Proving that there is a connection between the sovereignty of power and the preservation of the state is in itself not particularly difficult; what may arouse doubts is the necessity of preserving the state as seen from a subjective individual perspective. Hobbes pays a lot of attention to it, while Bodin contents himself with justifying sovereign power in the context of state institutions themselves. Thus Hobbes legitimises the institution of sovereign power much more thoroughly than Bodin, making fundamental use here precisely of his peculiar doctrine of representation.

Connecting the sovereign's authority with the will to survive, Hobbes also justifies it more fundamentally than is allowed by the republican doctrine of 'bottom-up' representation invoked by Marsilius. One may say that according to Hobbes, the authority legitimising itself in such a way should stand up to competition on the part of any authority that invokes some other political value. Only an authority that represents something even more important than 'bare life', i.e. eternal life, might locate itself above it: thus, it is not an accident that Hobbes opposes the false prophets, who believe power to be God-given, with even deeper commitment than the infectious republican doctrines flowing in from the Netherlands.

What is meant to prevent the outbidding of the values represented by the authority is the strong assumption concerning the finite character of human life, and, consequently, the limited goals of the state. It is meant to serve the protection of life from the beginning until its natural end, which means to Hobbes that the government is to protect a man from dying at the hands of another 'natural' man. When the sovereign authority itself wants to deprive the citizen of that

220 On whether Bodin may also be counted among the representatives of this school, cf. Lewis, 'Jean Bodin's', p. 215-216. 
protection and condemns him to death (which it naturally has the right to do in order to protect the lives of others), the citizen re-enters the relationship proper to the state of nature vis-ŕ-vis that authority. In such a case, he is entitled, or one might say obliged even, if one should take the laws of nature in whole seriousness, to take up arms to defend his life. As regards the citizen's life after death, the state is no longer interested in it, just like the citizen is no longer interested in a failed state, unable to guarantee his safety.

Because in Hobbes' writings the sovereign's authority always has its justification in the subjective arguments of individuals, rather than in the objective arguments of a community, it is less social as compared to Bodin's doctrine. The fact that social life emerges under the auspices of an authority, and that, by establishing relations between themselves, people create everything that is best in it (scholarship, art and the economy), does not make them a community under the rule of that authority. The concept of commonwealth, which Hobbes uses to describe the state, is perverse and misleading. Actually, the citizens may not even say that they live under a common authority; all they may say is that they have an authority common to all of them, which only means that each of them separately is subject to the same authority. Consequently, it is a much more essential difference than the linguistic formula itself might suggest, as it imparts an existential character to expectations vis-ŕ-vis the sovereign and, most importantly, to obligations towards him. Power is always a relationship between the sovereign and the individual. Paradoxically, Hobbes' construction must have seemed familiar to the Puritans, much loathed by him, to whom a man always stands before God on his own, without the agency or support of the institutions of the Church, which is nothing more than a secular organisation of believers.

Thus Hobbes, who derives power from the people, seeks to make it independent of society, since, just like the Church, it is exposed to various kinds of heresies, turning man away from the true faith and the true political science. Even though the author of Leviathan obviously has a great deal to say about the importance of government for social life, he makes the subjective belief of individuals that only an authority ensures their individual survival the ultimate rationale for it. Sovereign power represents the ultimate, absolute value, which man is unable to ensure for himself on his own; it is only, thanks to that power, that he is capable of cooperation with others, and that only because they are subject to it as well. 



\section{Representation and a limitation of power}

\section{A limitation of power, or the security of the ruled}

A limitation of power, as already mentioned in the Introduction, is a function of the institution of representation, a function that it fulfilled as early as in the feudal system. A Roman maxim, Quod omnes tangit ab omnibus approbetur (what touches all is to be approved by all), which became a time-honoured custom or law of many lands in Christian Europe, is often cited as its justification. Hobbes' theory deprives representation of this function; it is the government that now represents the ruled, and therefore it need not be subject to any limitations related to the representation of the estates. The limitation of power to be discussed in the present chapter concerns modern representative government; therefore, it can no longer invoke the laws taken into consideration by Jean Bodin. As secularised political power comes from the people, it must be limited by the people. Accordingly, in place of divine laws, there appears first the vigilance of the people, then human nature and eventually man-made institutions.

John Locke is usually assigned to the same current in political theory as Thomas Hobbes, but there are several themes in his thought belonging to a tradition resolutely rejected by the author of Leviathan. Even though Locke does not deny the necessity of strong government, he seems to be closer to Aristotle's view that people are by nature creatures inclined towards cooperation, and that it is to cooperation that they ultimately owe their life, security and prosperity. Locke thus follows Hobbes in defining the goals of the state, but he wants to achieve them in a different way, for he regards the solution proposed by that philosopher as posing a bigger problem than the one it was supposed to solve.

Locke believes that by taking government outside society, Hobbes indeed considerably reduced the threats resulting from human coexistence by means of his particular doctrine of representation, but by the same token, he massively augmented the danger posed by a government remaining outside social control. That is why Locke, without depriving the government of the ability to act effectively, wants to locate it once again within society by means of representation, for he fears an alienated government more than a weak government. While the author of Leviathan regards absolute power as a condition for the survival of every individual, Locke sees it as a mortal threat to people exposed to its omnipotence.

Unlike Locke, Charles Louis de Secondat Montesquieu openly criticises Hobbes and his doctrine. Having examined the systems of government of European and Asian states, he comes to the conclusion that despotism is not a 
degeneration of monarchy, but a political system with its own 'spirit'. Even though it is the only system of government contrary to human nature, it is the most widespread in the world. The peoples shaped within it are almost condemned to it, even if one cannot speak here of a logical necessity, but merely of some regularities observed by Montesquieu - 'necessary relations deriving from the nature of things', as he defines laws in the broadest sense at the start of his magnum opus. However, in order to find a safeguard against despotism, the author of The Spirit of the Laws does not design an entire (theoretical) system of government with a view to securing freedom, the way philosophers do; all he does is inquire sociologically, one might say, as to what kind of institutions are necessary to that end and what type of society would allow them to function properly ${ }^{221}$.

Montesquieu opens his work by invoking Aristotle's classification of forms of government; he modifies it, but without introducing the idea of representation in his discussion. It is not even mentioned in Book 9, the book devoted to a particular form of government, i.e. to the federal republic. The institution does not appear until Chapter 6 of Book 11 when the system of government in England is discussed ${ }^{222}$; the subject recurs in Chapter 27 of Book 19, in which the author

221 Raymond Aron's view is characteristic here: he regards Montesquieu both as a classical philosopher for whom the political system determines the shape of society, and as a sociologist who reinterprets classical political thought from the perspective of a more general social theory and ultimately explains all aspects of communal life in sociological terms; cf. Raymond Aron, Main Currents in Sociological Thought (Harmondsworth, U.K.: Penguin Books, 1986), 1, p. 61-62. Isaiah Berlin on his part views Montesquieu only as an empiricist who had inherited certain metaphysical concepts; cf. Isaiah Berlin, Against the Current: Essays in the History of Ideas (New York: The Viking Press, 1980), p. 137. It is a separate question whether in the case of The Spirit of the Laws one may speak of any kind of work plan. According to Berlin, we absolutely may not (p. 131-132), but historians of political thought from Leo Strauss' school, invoking an explanation provided by Montesquieu to d'Alambert, speak of a hidden order as well as of hidden ideas: the truths the author could not clearly expound; cf. Lowenthal, 'Montesquieu', p. 514-515; for more on the subject see Thomas L. Pangle, Montesquieu's Philosophy of Liberalism. A Commentary on "The Spirit of the Laws" (Chicago - London: University of Chicago Press, 1973), p. 11-19.

222 To Montesquieu, Judith Shklar observes, England is actually neither a feudal monarchy nor a classical republic: it is a modern constitutional state, 'a democracy disguised as a monarchy' (cf. Judith N. Shklar, 'Montesquieu and the New Republicanism,' in: Political Thought and Political Thinkers [Chicago - London: University of Chicago Press, 1998], p. 248); nor is it an ideal form of government, for one actually cannot speak of such in Montesquieu's thought, but simply a state providing the best possible alternative to 
explains why representative government in that particular country effectively protects the subjects' freedom.

Locke's and Montesquieu's teachings were used by the founders of the first democratic republic and the authors of its constitution, and Alexander Hamilton, James Madison and John Jay then undertook the effort of winning 'the People of the State of New York' and other states over to $i^{223}$. They did not share the belief, widespread in the 18 th century, that commerce sublimates human passions ${ }^{224}$, which they regarded as the greatest threat to the freedom and security of the citizenry. Unlike the ancient critics of democracy, who feared first and foremost the changeability of popular rule, they were more afraid of the permanence of popular rule, viewing this continuity as a potential threat of discrimination against and persecution of all kinds of minorities, including an expropriation of the property-holding classes by the poor majority ${ }^{225}$.

Admittedly, they did also see a threat to the citizens' security in the institution of government itself, but, without diminishing it, they believed that the 'powerful means' delivered by the contemporary 'science of politics' and unknown to the ancient 'friends to liberty', would be able to prevent it. Hamilton enumerated Locke's and Montesquieu's most important 'inventions': a formal separation of powers by legislative balances and checks, the irrevocability of judges during their term of office and, last but not least, direct election of representatives to the legislature; even if these were not new solutions, they had been considerably perfected recently, federalists claimed ${ }^{226}$. As power derives from the people, the people may constitute it from the very beginning in a limited form.

despotism; cf. Judith N. Shklar, Montesquieu (Oxford - New York: Oxford University Press, 1987), p. 88, 112.

223 The first two authors (Jay wrote only three essays) differed considerably in their political opinions, and yet the whole collection of eighty-five essays is surprisingly consistent and combines, in an amazingly coherent way, theory with the authors' views on the current political situation; cf. Martin Diamond, 'The Federalist', in: History of Political Philosophy, ed. Strauss, Cropsey, p. 660-661, 663-664.

224 Alexander Hamilton, James Madison and John Jay, The Federalist with Letters of "Brutus," ed. Terence Ball, (Cambridge University Press, Cambridge 2003), No. 6, p. 19-24.

225 Cf. Manin, The Principles, p. 124.

226 Cf. Hamilton, Madison and Jay, The Federalist, No. 9, p. 36. 


\section{A representative government of a political society: Second Treatise of the Government by John Locke}

Even though Locke enters into an open polemic with Sir Robert Filmer's Patriarcha, or the Natural Power of King (a work which actually does not mention the state of nature), the philosopher's fundamental argument against absolute power does not actually refer to Filmer's work at all, but to Hobbes' Leviathan ${ }^{227}$. An absolute ruler instituted by a contract between individuals concluded in order to get out of the state of nature does not himself belong to political society, which means that he remains in the state of nature vis-à-vis its every member. He makes laws in order to prevent enmities between his subjects from turning into open aggression, but he himself is not subject to those laws ${ }^{228}$. A question suggests itself, and Locke poses it regardless of Hobbes' arguments:

227 Hobbes' name is not mentioned at all in the Second Treatise of Government; there is one mention of 'the mighty Leviathan', which would be powerless if the government had to be constituted by the consent of every individual rather than by the consent of the majority of a political society; cf. John Locke, The Second Treatise of Government in: Two Treatises of Government (Cambridge - New York - New Rochelle - Melbourne - Sydney: Cambridge University Press, 1988), §98, p. 332-333. Leo Strauss claims that Locke was a prudent man who knew what he could discuss and what he should pass over in silence, and 'judiciously refrained as much as he could from mentioning Hobbes's "justly decried name"; Leo Strauss, Natural Right and History. A Cogent Examination of One of the Most Significant Issues in Modern Political and Social History (The University Of Chicago Press, Chicago \& London, 1965), p. 166. Peter Laslett on his part observes that even though Locke thoroughly knew Hobbes' work and 'never escaped the shadow of Leviathan', he did not refer to or comment on any of his ideas in his Treatise; cf. Peter Laslett, 'Introduction,' in: John Locke, Two Treatises of Government (Cambridge - New York - New Rochelle - Melbourne Sydney: Cambridge University Press, 1988), p. 72-74. Locke actually enters into a polemic with only one argument put forward by Filmer that is not found in Hobbes's work; Filmer derives political power from natural parental rights to children, while Locke argues that according to common law the father's power over his offspring is by no means absolute; cf. Locke, The Second Treatise, $\$ 64-67$, p. 310-312. Laslett writes extensively on Hobbes' and Filmer's influences on Locke's work; see Laslett, 'Introduction', p. 67-92.

228 That is why absolutism is prima facie contrary to God-given laws. An absolute ruler holds completely arbitrary power over the lives of other people, and no man on earth may hold this kind of power even over his own life, for, as God's creature, he belongs to his Maker (this fails to apply only in the case of prisoners of war seized in a legitimate and justified war, as their captivity results from a continuation of the state of 
what Security, what Fence is there in such a State, against the Violence and Oppression of this Absolute Ruler?. To ask how you may be guarded from harm, or injury on that side where the strongest hand is to do it, is presently the Voice of Faction and Rebellion. As if when Men quitting the State of Nature entered into Society, they agreed that all of them but one, should be under the restraint of Laws, but that he should retain all the Liberty of the State of Nature, increased with Power, and made licentious by Impunity. This is to think that Men are so foolish that they take care to avoid what Mischiefs may be done them by Pole-Cats, or Foxes, but are content, nay think it Safety, to be devoured by Lions $^{229}$.

Obviously, the choice of animals is not accidental here; small animals may bite people, while big animals devour them. Life in the state of nature is almost an idyll as compared to living under the rule of an autocrat, whether he is called a tsar or a great doge. That metaphor contains the essence of Locke's argument against absolute power. For man is not so evil - absolutely evil, let us say - that his natural instincts may only be curbed by absolute power. Nor is he good; in any case, he has not in himself that potential for good that ancient philosophers attribute to him. People are only potentially evil, so all the government has to do is prevent the state of nature, which is basically a peaceful state, from turning into a state of war: that is what political society emerges for ${ }^{230}$. It is not a reverse of the state of nature, but rather its continuation and improvement.

For according to Locke man is a social being; in the state of nature, there are natural ties between people, similar to those presented by Aristotle in the first book of Politics. People cooperate with one another, and even trade using money, rather than barter, so there are even conventions. Man's natural enemy in the state of nature is nature itself, which does not provide sufficient conditions for human survival. However, man is more often driven by the weakness of reason than by ill-will to break natural laws. Preoccupied by work, by wresting riches

war; cf. Locke, The Second Treatise, $\$ 172$, p. 382-383). Locke derives man's obligation to preserve his life precisely from the Maker's right to possess its creation.

229 Locke, The Second Treatise, $\$ 93$, p. 328.

230 Pierre Manent writes more extensively on the subject; cf. Manent, An Intellectual, p. 47-48. Leo Strauss observes that Locke's state of nature, as seen from the biblical perspective, 'is not identical with either the state of innocence or the state after the Fall. If there is any place at all in biblical history for Locke's state of nature, the state of nature would begin after the flood, i.e., a long time after the Fall'; Strauss, Natural Right, p. 215-216. In the literature (including Strauss' book cited above), there is also talk about two variants of Locke's state of nature; on the subject, see Zbigniew Rau, 'Wstęp', in: John Locke, Dwa traktaty o rzadzie, trans. Zbigniew Rau (Warszawa: Wydawnictwo Naukowe PWN, 1992), p. XXXIX-XL. 
from nature, people do not particularly want to harm one another; they do it as much to benefit themselves as for prevention, pre-empting a potential attack on themselves and their property. Thus, according to Locke, government is established more out of solicitude for a quiet life than out of fear of a sudden death, as assumed by Hobbes; people crave security, security being a state in which they enjoy, unimpeded, their natural right to property. Defining human life in terms of possession - self-possession - Locke declares succinctly that a commonwealth arises in order to protect property ${ }^{231}$.

While analysing this problem, he provides three arguments that, taken together, argue for leaving the state of nature ${ }^{232}$. Firstly, in the state of nature, there is no 'established, settled, known Law'; people, preoccupied with their business, do not study the law of nature, and consequently fail to see that it applies to their own problems. Secondly, in that state, there is no 'known and indifferent Judge', and being naturally inclined towards egoism, people may not be judges in their own cases, while in other people's cases they will be dilatory or careless. Thirdly and finally, there is no 'Power to back and support the Sentence when right, and to give it due Execution'; what is needed here is simply a force capable of subduing the strongest offenders. Entering into a social contract, people undertake vis-à-vis one another not to be guided by what the law of nature dictates to them in case of conflict.

Thus, a government arises out of the need for justice and out of recognition that it is impossible to institute it within a community without granting special rights to certain individuals, though not because these individuals are distinguished by a sharpened sense of justice. In this respect, people are equal, or at least equal, to such an extent that no particular individual merits these rights unconditionally. That is why, in Locke's opinion, only one type of government may guarantee security to those who remain under its rule, i.e. a representative government, in which government is elected and power exercised by people who themselves belong to political society.

The representative character of political government lies, therefore, in the very nature of public power, and that is one thing that makes it different from

231 Cf. Locke, The Second Treatise, $\$ 123$, p. 350: 'And 'tis not without reason, that he seeks out, and is willing to joyn in Society with others who are already united, or have a mind to unite for the mutual Preservation of their Lives, Liberties and Estates, which I call by the general Name, Property'.

232 Cf. Locke, The Second Treatise, $\$ 124-126$, p. 350-352. 
parental, private power. Political power is as much power over oneself as power for itself, i.e. for the people constituting a community living under one law.

Political Power then I take to be a Right of making Laws with Penalties of Death, and consequently all less Penalties, for the Regulating and Preserving of Property, and of employing the force of the Community, in the Execution of such Laws, and in the defence of the Common-wealth from Foreign Injury, and all this only for the Publick $\operatorname{Good}^{233}$.

Even though Locke is distant from Hobbes' idea that it is only government that makes possible communal life for people, neither does he say clearly that it is established by a community which exists and may exist independently of it. The image of man living in the state of nature, no less distinctive but much less dramatic than that presented by Hobbes, is merely intended to persuade the reader of the Treatise that a community can afford to change its government, i.e. that between removing some people from power and appointing some others, or even during the change of an entire system of government, it will not plunge into the turmoil of a civil war ${ }^{234}$.

Perhaps because that conclusion follows already from his analysis of the state of nature, not much attention is paid to Locke's distinction between the two stages of the contract owing to which people emerge from that state. This is understandable to a certain extent, given that the philosopher himself does not dwell on the issue, while in the context of this book it is crucial, for it is political society that has emerged at the first stage of the contract that appoints representative government at its second stage.

For representative government in Locke's theory is usually reduced by commentators to the institution of parliament, while in the state described in The Second Treatise each government is in fact representative, including the king's executive power. Such an interpretation of Locke's thought goes beyond the letter of the text, and perhaps that is why, it is not particularly popular ${ }^{235}$. However, neither does it stand in contradiction to the views stated expressly by

233 Locke, The Second Treatise, $\$ 3$, p. 268.

234 Locke's theory as expounded in The Treatise, its editor Peter Laslett argues, abounds in understatements, however, and many conclusions may only be drawn from its general tone; nonetheless, the understatements do not obscure the principles on which the government is founded; cf. Laslett, 'Introduction', p. 116-117. In fact Locke altogether fails to consider the question of what overthrowing a government would lead to.

235 In fact, from among the literature quoted here only Pierre Manent's work upholds it; Carole Pateman does note the problem, but makes little of it; cf. Carole Pateman, The Problem of Political Obligation (Cambridge: Polity Press, 1979), p. 68-70. 
the philosopher; it does not even require resorting to Strauss' methodology of reading between the lines, as on this particular point Locke's philosophy was not 'subversive' and did not have to be concealed from unwelcome readers. On the other hand, one has to admit that in the pre-revolutionary period, it could have been used and abused by the supporters of the ruling House of Stuart, which would have gone very much against Locke's intentions ${ }^{236}$.

Political society (also known as civil society), which emerged at the first stage of the social contract, may be described as a community of people obliged towards one another to respect the law. Hobbes naturally precludes the existence of such a community without the sovereign's sword hanging above the people to remind them of their obligation, but Locke himself also sees a certain problem here, manifesting itself in the lack of a proper term for describing that state of society. Consequently, he writes:

By Common-wealth, I must be understood all along to mean, not a Democracy, or any Form of Government, but any Independent Community which the Latines signified by the word Civitas, to which the word which best answers in our Language, is Commonwealth, and most properly expresses such a Society of Men, which Community or Citty in English does not, for there may be Subordinate Communities in a Government; and City amongst us has a quite different notion from Commonwealth: And therefore to avoid ambiguity, I crave leave to use the word Commonwealth in that sense, in which

236 Earlier historiography generally regarded the state described by Locke in the Treatise as a model of the political system that emerged in England after the Glorious Revolution, even though, as proved by Peter Laslett, The Second Treatise was written prior to 1688 and cannot be regarded as an apology of that revolution. Obviously, this does not exclude a possibility that some changes might have been introduced later, but in Laslett's opinion it would have been completely inconsistent with Locke's character to provide ideological explanations for anybody or anything; cf. Laslett, 'Introduction,' p. 46-48, 53. Present-day historical interpretations of Locke's thought tend to stress, rather, that The Treatise belongs to the English constitutional tradition and attribute to it a desire not so much to invent a new form of community as to 'reinvent' an established form. The form of the treatise that suggests creating a state $a b$ initio is alleged to have only been imposed by historical circumstances, and more precisely by the type of religiosity of the English nobility; cf. John Dunn, 'Consent in the Political Theory of John Locke', in: Political Obligation in its Historical Context (Cambridge: Cambridge University Press, 1980), p. 36, 57. To defend the dissidents from persecution by the Crown, Locke needed a kind of theory that would impose restrictions on government without destroying the existing order; cf. James Tuly, An Approach to Political Philosophy: Locke in Contexts (Cambridge: Cambridge University Press, 1993), p. 9, 320. 
I find it used by King James the First, and I take it to be its genuine signification; which if any Body dislike, I consent with him to change it for a better ${ }^{237}$.

Such a commonwealth emerges even before the parties to the contract elect any kind of government, or an institution for settling disputes for themselves, but after the individuals have already renounced that natural right. Thus, the power of judging belongs to political society as a whole. Will that body be capable of judging communally, however, if it has not established a relevant institution ${ }^{238}$ ? How would decisions be made? Who would have the decisive voice? Even the majority principle is not obvious in that state. People undertake to entrust the settlement of disputes to an impartial judge, but if there is no judge as yet, that obligation itself seems nonsensical.

Actually, it has an important meaning, and a double meaning at that. Even if the first stage of the contract may only be distinguished conceptually, for in historical time it actually does not occur (while removing a despotic ruler, the rebels, unless they want to establish a republic, usually have a pretender to the throne already), and in the logical order it is only an introduction to the second stage ${ }^{239}$, in the normative order it plays a no less important, if not a more important, role. Firstly, it is a declaration of a willingness to live within a community irrespective of its form: having once established political society, individuals undertake vis-àvis one another never to return to the state of nature ${ }^{240}$, i.e. to agree on some form of government. Secondly, as has already been said, it makes it possible to change this form without dissolving the community itself. In deposing government, the commonwealth does not relapse into the state of nature, but remains a political body, and therefore need not fear lawlessness; even though there are no enacted laws any longer (or not yet), laws of nature govern within the community at all times, whether there is an established government or not.

237 Locke, The Second Treatise, $\$ 133$, p. 355. It is disputable whether Locke believed that any society had actually lived in the state of nature; that is of no relevance to representation itself, however, and even, as Strauss and other students of Locke's thought have believed, to the understanding of his Treatise in general; cf. Strauss, Natural Right, p. 231.

238 Robert A. Goldwin observes: 'Political society without government can do nothing but make government'; cf. Robert A. Goldwin, 'John Locke,' in: History of Political Philosophy, ed. Strauss, Cropsey, p. 500.

239 Cf. Pateman, The Problem, p. 68-70. This chapter is therefore, in a sense, a polemic with this view.

240 Cf. Locke, The Second Treatise, \$121, p. 349. 
An important reservation needs to be highlighted here concerning this statement: the term 'commonwealth' seems too strong to describe political society, even if Locke himself uses it for want of a better one. Certainly political society is not a community of the same kind as demos, given that it is nothing more than a gathering of individuals united by a desire to live in peace and security. It has no collective identity. Whether society members are connected by economic or ethnic ties, both kinds of ties or none at all, what is constitutive of their union is only the obligation to live in accordance with the laws laid down collectively. Political society in this sense is not, admittedly, a mere collection or conglomerate of individuals once it has been conceptualised as a whole by means of a contract; nonetheless, its members are not united by, e.g., patriotism or republican brotherhood, but rather by loyalty towards the other signatories to the contract, each of them separately. That is why Robert Nozick, regarding Locke as the patron of libertarian state theory, argues that all that emerges as a result of the contract is a private security society, though with a greater outreach than the others, which makes it the dominating society ${ }^{241}$.

Following Michael Oakeshott, the newly emerged commonwealth may also be interpreted in a more communal sense. Oakeshott calls that state 'civil' and, like Locke, uses the Latin term civitas to describe it. He stresses, more strongly than Locke, the strictly political character of that association, not deriving the political will to coexist even from its members' need to ensure elementary security for themselves. Respublica - for this is another name for that association - is legalised in terms of its own language, in which there is no reference to any kind of benefits, but only to justice.

The practice in terms of which cives emerge and are related to one another is unlike some other practices in being composed entirely of rules; the language of civil intercourse is a language of rules; civitas is a rule-articulated association ${ }^{242}$.

It is laws, rather than shared mores or communication between individuals as such, that bind them within a political community; these laws should not be mistaken for the government that makes them.

Locke's political society existing between the first and the second stages of the contract is not a civitas in the above sense, however, as there are no enacted laws in force in it, only natural laws, compliance with which depends solely on

241 Cf. Robert Nozick, Anarchy, State, Utopia (Oxford UK \& Cambridge USA: Blackwell, 1999), p. 12-15.

242 Michael Oakeshott, On Human Conduct (Oxford: Clarendon Press/Oxford University Press, 2003), p. 124. 
individual goodwill. On the other hand, it is something more than a mere private association set up for common defence, as its members are aware that they are establishing an indissoluble bond among themselves and taking measures to uphold it; that is why, they elect a judge and organise a force capable of enforcing his verdicts. It is not only the status of that community that is problematic. What kind of rules does that community follow in selecting the form of government? How does one derive the principles of government from the very desire to live together? The laws of nature, the only ones in existence at that time, do not cover this aspect, for they are not unambiguous enough to base on them any kind of procedure for constituting a government. Thus, to Locke the constituting of government is no lesser a problem than to Hobbes, a much bigger problem in fact. For having no statute law, political society must not only select the form of government, but also limit the extent of its powers; once established, the government will not be inclined to impose any limitations upon itself, and for the sake of individual security, some kind of limitations have to be instituted ${ }^{243}$. Actually, in order to elect this kind of government, political society needs a statute preceding all other statutes: a basic law, or a constitution in the present-day sense. But if a present-day constitution is created by the will of a political 'nation', in political society there are still only the wills of individuals.

Thus, Locke makes a characteristic shift here, proceeding immediately from the wills of individuals to legislative bodies with limited competences. Perhaps aware of this non sequitur in his own argument, he discreetly ignores the problem itself. In Hobbes' theory, in which the transition from an individual will for survival to a common desire to appoint a sovereign remains a mystery, the problem indeed does not occur, since power, concentrated in the hands of a single individual or a single assembly, may not be limited, either at the moment of his/its appointment or later; the appointment of government through a single decision is tantamount to an emergence of a political community. However, both in Hobbes' theory and in Locke's argument, the origins of government were ultimately subordinated to the justification of its form: absolute in Leviathan, and representative in the Treatise; looking at the 'chronology' of the process of appointment of government, one can easily notice its characteristic lack of continuity.

243 Rau points to a broader, ethical dimension of representation-trusteeship, overlapping with the theological aspect: 'The obligation to be trustworthy was imposed by God and is among the provisions of the law of nature. Locke stresses that compliance with contracts is an imperative of an individual as a human, rather than as a member of civic society'; cf. Rau, 'Wstęp', p. LXXXIX; see also Zbigniew Ogonowski, Locke (Warszawa: Książka i Wiedza, 1972), p. 186. 
With rare exceptions, such lack of continuity is not to be observed in the histories of individual states, and it seems that only the perturbations in European integration have made people realise that it is not an abstract problem ${ }^{244}$. The rejection of the Euroconstitution illustrates well the difficulties of transition from the first to the second stage of the social contract, as it becomes necessary to conclude a purely political agreement. One may say that Locke conceptualised, though he actually merely indicated, a problem solved in the practice of European states by the tradition of hereditary monarchy. After this tradition was severed during the French Revolution, the state, or more precisely political society, for several years sought a form of government appropriate for itself. The European political society, established by successive international treaties, is barely several decades old, not much compared to the more than one thousand year long history of France, so the birth pangs of a possible future state should not come as a surprise. However, this is where an analogy between it and Locke's political society ends. For while the Europeans' personal safety is guaranteed by their national governments, in the social condition that emerged after the first stage of the contract, it is still in the hands of individuals themselves, and this is what pushes them towards establishing representative government.

In the most general sense, representative government means to Locke a government accountable to those that it rules by their consent ${ }^{245}$. Incidentally, the said consent is not always as spectacular as in the case of a state established by means of a classical contract. Examples are furnished here by revolutions, but only by those glorious ones in which government is not imposed upon the ruled or upheld by terror. The situations in which government is established occur rarely, however, so how can one see that consent in the existing political order? Whence can we infer that it is not founded on force alone? Characteristically, Locke's answer does not invoke the origins of government, but rather the manner in which it discharges its function: the consent of the ruled means a lack of opposition from them ${ }^{246}$.

244 For more on the subject, see Andrzej Waśkiewicz, 'John Locke i problem integracji europejskiej, in: Dawne idee, nowe problemy, ed. Paweł Śpiewak (Warszawa: Wydawnictwa Uniwersytetu Warszawskiego, 2010).

245 According to Pateman, this formula is pertinent and inclusive enough to still remain a reference point for legitimisation theory; cf. Pateman, The Problem, p. 61.

246 Only in one case, John Plamenatz observes, must consent be spoken: in the case of taxation, which in his opinion makes Locke's theory inconsistent; cf. Plamenatz, Man and Society, I, p. 353-354. 
And to this I say, that every Man, that hath any Possession, or Enjoyment, of any part of the Dominions of any Government, doth thereby give his tacit Consent, and is as far forth obliged to Obedience to the Laws of that Government, during such Enjoyment, as any one under it; whether this his Possession be of Land, to him and his Heirs forever, or a Lodging only for a Week; or whether it be barely travelling freely on the Highway; and in Effect, it reaches as far as the very being of any one within the Territories of that Government ${ }^{247}$.

In criticising the idea of social contract, those who follow David Hume are undoubtedly right: one can hardly imagine a peasant or a craftsman who does not approve of the government and therefore sells his property and goes abroad; the travel expenses would deprive him of everything he owns, and the lack of knowledge of the local language and customs would make his life abroad unbearable. However, the lack of means allowing effective protest against the government is not the same as the lack of the right to express it. For it is not every government that allows its opponents, be they rich or poor, to leave the country with all their property. A non-liberal government, unless it imprisons them, will, rather, remove them forcibly, requisitioning their property; by contrast, a government that wields power with the consent of the ruled will tolerate them, even if they obey its laws exclusively out of fear. As it is equally difficult to imagine a government that part of the ruled would not barely tolerate, the proof and yardstick of its actual repressiveness will be the presence of the category of the ruled who are not allowed to emigrate or, alternatively, made to emigrate. Thus, a government that wields power with the consent of the ruled is also, in a sense, not accepted, or even imposed, but borne on condition that it does not excessively oppress the subjects.

In practice, it is only in those rare moments when political society openly refuses consent to one government that it can elect another for itself. Nonetheless, Locke seems to downplay the importance of the choice of the form of government no less than Hobbes does, with the obvious difference that while the author of Leviathan stresses the absolute character of power, the author of The Second Treatise emphasises its limited scope. As the form of government in a given state is determined by the location of the supreme branch of government, or the legislature, it is better, claims Locke (though he does not elaborate on the subject), when laws are made by an assembly, because it is less likely to have designs on the citizens' property ${ }^{248}$. The shape of the legislature and of the remaining branches

247 Locke, The Second Treatise, $\$ 119$, p. 348.

248 Locke writes: 'He being in a much worse condition who is exposed to the Arbitrary Power of one Man, who has the command of 100 000, than he that is expos'd to the Arbitrary Power of 100000 single Men’; Locke, The Second Treatise, §137, p. 359-360. 
of government is decided by the opinion of a majority of those who have united themselves to form political society ${ }^{249}$. For practical reasons, executive power and federal power, looking after the state's external security and its interests abroad, may be united in the hands of a hereditary monarch.

Chapter 10 of The Second Treatise, dealing with this subject and entitled 'Of the Forms of a Commonwealth', is by far the shortest of all and consists merely of two paragraphs, one of which includes the definition of the political commonwealth quoted above. Naturally, Locke's considerations on institutions of power may not stop at that: it is just that he is no longer preoccupied with the question of who - one, many or all - is to exercise power, but merely that of what falls within the ruler's competences.

The legislature is indisputably the most important power in the state. Writing about it, Locke, whose language is much less dramatic than Hobbes', goes as far as to use almost religious expressions: 'This Legislative is not only the supream power of the Common-wealth, but sacred and unalterable in the hands where the Community have once placed it ${ }^{250}$. Its actual sacralisation is, however, out of the question; even this power is ultimately an institution designed to serve those who established it:

the first and fundamental positive Law of all Common-wealths, is the establishing of the Legislative Power; as the first and fundamental natural Law, which is to govern even the Legislative it self, is the preservation of the Society, and (as far as will consist with the publick good) of every person in it $\mathrm{it}^{251}$.

It is evident already from the excerpt quoted above what kind of benefit Locke draws from introducing two stages of the social contract. While the rationale behind establishing political society is the security of each individual, the legislative cares for the security of the newly established commonwealth and only indirectly for the security of individuals. Perhaps one should not draw too-farreaching conclusions from this difference - in any case, Locke himself does not

That is why Plamenatz criticises Locke for overlooking the fact that the consent granted by the citizens to the government ultimately depends on the form of government; cf. Plamenatz, Man and Society, I, p. 363; he describes the system created by Locke as a liberal aristocracy; cf. vol. I, p. 378.

249 Cf. Locke, The Second Treatise, $\$ 132$, p. 354. According to Jacqueline Stevens, this view, not justified by Locke, is dictated by pure pragmatism (that is why, some scholars question the philosopher's individualism); cf. Jacqueline Stevens, 'The Reasonableness of John Locke's Majority', Political Theory, Vol. 24, No. 3 (1996), p. $444 \mathrm{ff}$.

250 Locke, The Second Treatise, \$134, p. 356.

251 Locke, The Second Treatise, $\$ 134$, p. 355-356. 
do so; nonetheless, it indicates that the newly emerged community may no longer be regarded as a private association. Conflicts within it are not merely conflicts between individuals, but also between the interests of the commonwealth and the interests of particular individuals. As long as there is no legislative, there is no institution to care for the common welfare of the community made up of individuals associated with one another. The legislative protects the individual welfare of each of them, as it makes laws allowing a resolution of conflicts occurring among them, but also expresses their communal welfare, irreducible to individual welfares. Exercising power over individuals, it is at the same time a power serving the community which brought it into existence.

In the second part of The Second Treatise, Locke obliterates the difference between the two stages of the social contract, ignores the natural bonds between people and their mutual obligations, and presents the legislative as the necessary condition for the existence of any commonwealth. While his argument on that matter may not be as clear as that of Hobbes, its sense is identical: without government, there is no community that may be assured of its survival. Locke writes about this loftily:

'tis in their Legislative, that the Members of a Commonwealth are united, and combined together into one coherent living Body. This is the Soul that gives Form, Life, and Unity to the Commonwealth: From hence the several Members have their mutual Influence, Sympathy, and Connexion: And therefore when the Legislative is broken, or dissolved, Dissolution and Death follows. For the Essence and Union of the Society consisting in having one Will, the Legislative, when once established by the Majority, has the declaring, and as it were keeping of that Will ${ }^{252}$.

Further on, Locke goes on to write once again about society existing independently of government, yet still only in the context of that society proceeding to elect a government for itself:

The Constitution of the Legislative is the first and fundamental Act of Society, whereby provision is made for the Continuation of their [the people's - A.W.] Union, under the Direction of Persons, and Bonds of Laws made by persons authorized thereunto, by the Consent and Appointment of the People ${ }^{253}$.

The apparent contradiction contained in this quotation is resolved by the word 'continuation'. Political society arises without the participation of government, but it cannot continue without it; however, it can afford to change it. If the form of the commonwealth does not suit its members, they change the form of the

252 Locke, The Second Treatise, $\$ 212$, p. 407.

253 Locke, The Second Treatise, \$ 212, p. 407-408. 
legislative, handing over lawmaking to somebody else. In that sense, they also change the commonwealth itself, because Locke, speaking of its 'soul', seems to follow Aristotle in assuming that it is the form of government that determines its identity. It follows from the above that the state that emerged after the 'Glorious Revolution' should be regarded as a new state, as if it had been constituted precisely by way of a social contract. Paradoxically, Locke successfully combines here the ideas of Aristotle with those of Hobbes, though only according to a favourable interpretation. Those less favourably inclined among the students of his ideas will say that, motivated by ideological goals, he alternately invokes Hobbes and Aristotle, depending on whether he wants to justify the overthrowing of the old government or warn against attempts to overthrow the new one ${ }^{254}$.

This entanglement of a philosophical argument in a historical context is by no means obvious in the work under discussion, even if the author's attitude towards the revolution itself remains unequivocal. The Whig tradition regarded the parliament as the mainstay of freedom and a monarch's rule as a threat to it; meanwhile, Locke's philosophy is much more sophisticated on that point. This is true in particular of his views on the executive power. One could presume that the historical Locke should have strengthened the parliament against monarchs' designs, and yet the author of The Second Treatise is not afraid of a strong executive. By no means could a limitation of the executive be said to be the central theme of Locke's description of the institutions of power. Given that the object of the government is to ensure the citizens' security, obviously the executive power may not remain beyond their control, and supervisory functions over it will be exercised by the legislative.

Even so, the executive is not as dependent on the legislative as would seem to follow from their hierarchy alone, because its scope of action is extended by a prerogative. Prerogative, Locke claims, is

the Peoples permitting their Rulers, to do several things of their own free choice, where the Law was silent, and sometimes too against the direct Letter of the Law, for the publick good; and their acquiescing in it when so done $e^{255}$.

254 The least favourably inclined commentators of Locke's philosophy regard it simply as a set of arguments and opinions on various matters, presented in an abstract form. Indeed, the students of his philosophy generally tend to regard it as not very coherent; cf. Richard Ashcraft, 'Locke's Political Philosophy', in: The Cambridge Companion to Locke, ed. Vere Chappell (Cambridge: Cambridge University Press, 1994), p. 226. On the major differences in its interpretation, see Ogonowski, Locke, p. 168-183.

255 Locke, The Second Treatise, $\$ 164$, p. 377. 
The rights of the executive vis-à-vis the legislative are also justified by its origins; just like the latter, it derives directly from political society at a point when it has yet to hand over the supreme power to the legislative; if the hierarchy of powers were determined solely by the order in which they were constituted, the two powers would be equal to each other.

The right to conceptualise the common good might seem to be a particular attribute of the legislative; however, Locke grants this right to the executive as well. For its prerogative is

nothing, but a Power in the hands of the Prince to provide for the publick good, in such Cases, which depending on unforeseen and uncertain Occurrences, certain and unalterable Laws could not safely direct, whatsoever shall be done manifestly for the good of the People, and the establishing the Government upon its true Foundations, is, and always will be just Prerogative ${ }^{256}$.

Thus, the executive, even if it remains subordinated to the legislative in so far as it enforces the laws made by the latter, does not commit an abuse when it exceeds that mandate, as long as that benefits the community as a whole. That is why, Locke even admits that in a sense the executive can also be called the supreme power, given that it exercises the supreme power of enforcing laws ${ }^{257}$. The practical problem is of course how to determine whether some measure actually benefits the community or the government only, but by granting the executive the right to act for the community, Locke already entangles his theory in a major contradiction. For prior to the constitution of the legislative, one cannot speak of a common interest of political society as a whole, given that it is defined only by a lawmaking representative government: the community existing at that point is merely a union of individuals endowed with a desire to survive.

Another justification of the prerogative, without any reference to the common good this time, has a purely pragmatic character: the legislative cannot predict or plan how the developments unfold and, consequently, adjust the law to the situation. Consequently, strict and rigid adherence to old laws in a new situation may turn out to disadvantage the community.

Nay, 'tis fit that the Laws themselves should in some Cases give way to the Executive Power, or rather to this Fundamental Law of Nature and Government, viz. That as much as may be, all the Members of the Society are to be preserved ${ }^{258}$.

256 Locke, The Second Treatise, \$158, p. 373.

257 Cf. Locke, The Second Treatise, \$151, p. 368.

258 Locke, The Second Treatise, \$159, p. 375. 
This argument of Locke's is therefore free of the apparent lapse pointed out above. Actually, in such cases, the executive represents not so much the common good of political society as the desire to survive shared by each of its individual members. This means, however, that it is also representative, and its legitimacy is no less strong than the legitimacy of the legislative. The object of that power, and therefore its raison dêtre, is precisely the same as that of the legislative.

Accordingly, the two kinds of representation differ and thus complement each other. In its various aspects, the two powers represent the individual interests of members of political society, as well as their collective interests, even though their differentiation is expressed in the legislative only. Thus, it must not be the case, claims Locke, that proportions once established within the assembly have to be maintained, even though some cities have fallen, while others have thrived, but have no representatives in the legislative. Thereby, the assembly fails to reflect the existing population relations in 'just and undeniably equal measures'. Naturally, a change in the composition of the assembly by increasing its representativeness is not in the interest of the existing legislative, which is why this has to be accomplished by the executive, acting outside the law. It takes true casuistry for Locke to demonstrate the legitimacy of that change: what occurs when a major group of people acquires representation is not 'setting up a new Legislative', which is itself a rebellion ${ }^{259}$, but merely a transformation of the existing legislative.

For it being the interest, as well as intention of the People, to have a fair and equal

Representative; whoever brings it nearest to that, is an undoubted Friend and Establisher of the Government, and cannot miss the Consent and Approbation of the Community ${ }^{260}$.

It is in situations of this kind that the executive represents the body of the people against that part of the people which already has its representation in the legislative. It is not important that the executive itself - in Locke's time it was a hereditary monarchy - was not elected by the people, because its origins, as is the case in Hobbes' theory, are of secondary importance. If it rules with the consent of the ruled and in the name of the public good, it is a representative government. This is a condition that is more important than the manner in which it came into existence, so if this condition is not met by a government body elected by the people

259 Locke, The Second Treatise, $\$ 226$, p. 415.

260 Locke, The Second Treatise, $\$ 158$, p. 373. Nowhere does Locke explain, however, what those true, 'just' and 'undeniably equal' relations in representation actually are; all he says is that they are to be proportional to the numbers of the represented populace; cf. John W. Yolton, 'Representative', in: A Locke Dictionary (Oxford: Blackwell, 1993), p. 228. 
itself, i.e. the legislative, then either the people itself or the executive acting on its behalf may act for the common good against the existing law.

However, the fact that the legitimacy of both powers is equally strong is a potential source of fundamental conflict. Hobbes would say that it has to end in a civil war, i.e. by the people being deprived of any kind of security at some point; no form of diarchy is possible within a commonwealth. Locke is not afraid of that; he does not see a threat of a civil war nor of the government being paralysed. Once again, the two-phase conception of the social contract comes in handy, as it entails the existence of a community independent of government, reserving the right to settle disputes of that kind. To put it in present-day language, it has the competencies of a constitutional court.

Who shall be Judge whether the Prince or Legislative act contrary to their Trust? This [question - A. W.], perhaps, ill affected and factious Men may spread amongst the People, when the Prince only makes use of his due Prerogative. To this I reply, The People shall be Judge; for who shall be Judge whether his Trustee or Deputy acts well, and according to the Trust reposed in him, but he who deputes him, and must, by having deputed him have still a Power to discard him, when he fails in his Trust ${ }^{261}$ ?

Ultimately, the people becomes the highest power in the commonwealth; even though it does not rule directly, 'there remains still in the People a Supream Power to remove or alter the Legislative, when they find the Legislative act contrary to the trust reposed in them'. This is a wholly unexpected conclusion, given that there is no place for the people in the concept of the law of nature ${ }^{262}$. On this point, Locke thinks in an outrightly republican way, allowing power to be appointed for a limited time, and, even more crucially, arguing that the people has not renounced the right to change it as soon as it decides that the power has become a threat to the people. It could not hand over this natural right to its representatives, as self-preservation is the duty of the human race in keeping with the law of nature, and natural law does not lose its validity in civic society.

Seeking security, individuals who, having made a contract with one another in a commonwealth, have already become one people, cannot therefore simply appoint a government and then only go on obeying it. From Locke's argument, it

261 Locke, The Second Treatise, $\$ 240$, p. 426-427. Locke's statement that if the executive hinders the convening of the legislative, the people should forcibly remove it, becomes understandable in this context; cf. $\$ 155$, p. 370.

262 Locke, The Second Treatise, $\$ 149$, p. 367. Ogonowski supposes that Locke consciously did not use the word 'sovereign' here, so as to avoid any associations with Hobbes; cf. Ogonowski, Locke, p. 192. 
follows that they must remove a government that poses a threat to their freedom; they are able to do that precisely because at a time like that they do not withdraw into the state of nature, but merely to that stage in social life in which they are bound by a declaration to live in a community under a single government and may elect it again. A repeated election of government by political society, not provided for under the contract itself, is justified only when the existing government betrays its goal, which is to uphold civil society ${ }^{263}$. In the case of the executive, it means violating the laws made by the legislative, and the legislative itself is limited by superior natural law.

The first one of these limitations says that the government may not have 'an absolute arbitrary Power over their [the people's - A. W.] Persons and Estates ${ }^{264}$, given that it is a combined power of all members of society, placed in the hands of a single individual or assembly. The object of government is to preserve society, and therefore it must not destroy it. The other limitations follow, in a manner of speaking, from the first one. The legislative must administer justice and define the subjects' rights through publicly promulgated laws, with the assistance of appointed and recognised judges; it may not rule by means of arbitrary, ad hoc decrees, exposing political society to the whims of the ruler's will. Next, the supreme power must honour the natural property right, as the preservation of property is the aim for which the people set up civil society. It is from this limitation that the principle of taxation of the ruled exclusively with their consent follows, or more precisely with the consent of their representatives. Finally, the legislative may not hand over its lawmaking competencies to anybody else, as it is only a legislative power, and not a power that can appoint lawmakers; this right is vested in the people alone.

Some fragments of The Second Treatise and the aim generally attributed to it reveal that in Locke's opinion, it is actually the monarch - who, as a separate estate, may belong to the legislative - that will, either himself or through a faction organised by him, corrupt and intimidate the members of the house to gain control over it. If Locke had attributed these inclinations exclusively to the king, and not to the members of the representative body themselves, his theory would barely have gone beyond the mediaeval doctrine of opposition to tyrannical rule, adapted to new conditions. Meanwhile, he does not preclude the possibility that a representative power, deriving from the will of the people, may also assault the

263 Locke, The Second Treatise, $\$ 149$, p. 367.

264 Locke, The Second Treatise, $\$ 137$, p. 359. 
people's life, freedom and property, and that it will do so whenever it strives for absolute power or places it in the wrong hands.

Does Locke, therefore, discover the phenomenon known in political science as the alienation of power? It is not possible to answer this question definitively. Even though he appreciates the temptations involved in exercising power, he thinks of them in terms of individuals rather than institutions; the rulers' exceeding of their mandate is regarded not so much as an attribute of institutionalised power as a widespread weakness of human characters. The government threatens the subjects' security 'whether through ambition, fear, folly or corruption'; Locke has nothing more to say about it. Accordingly, it is easy for him to indicate a remedy to that weakness: different individuals ought to make laws and enforce them:

And because it may be too great a temptation to humane frailty apt to grasp at Power, for the same Persons who have the Power of making Laws, to have also in their hands the power to execute them, whereby they may exempt themselves from Obedience to the Laws they make, and suit the Law, both in its making and execution, to their own private advantage, and thereby come to have a distinct interest from the rest of the Community, contrary to the end of Society and Government... ${ }^{265}$.

In line with this general arrangement, Locke enumerates practical measures to prevent a concentration of power in the hands of a single individual. Besides the fundamental principle of functional division (one body makes laws and another enforces them), there is a rotation of the composition of the legislative ${ }^{266}$ and its convening by the executive (unless it convenes periodically by virtue of the law itself). Because the executive, despite its prerogative, is already restricted by law, the solutions provided by Locke are designed to limit the legislative, and it is actually thanks to them that the supreme power in the state is, in a manner of speaking, dependent on a power subordinate to it. Each of them is limited to a certain extent. Can one, therefore, legitimately attribute to Locke, even before Montesquieu, a separation of powers according to the checks and balances principle?

This view is only partially justified. If we look at his theory from the perspective of Hobbesian absolutism, in which sovereign power must by its very nature

265 Locke, The Second Treatise, $\$ 143$, p. 364.

266 Within the legislative, Locke distinguishes (in the first place!) an individual wielding, usually hereditary, chief executive power, next an assembly of hereditary nobility, and finally an assembly of representatives of the people elected for a limited period of time; cf. Locke, The Second Treatise, $\$ 213$, p. 408. 
be indivisible, then undoubtedly the setting up of two powers, no matter what kind of relationships exist between them, is a weakening of each of them ${ }^{267}$. If, however, it is the relationships between those powers that are the starting point, which is the essence of Montesquieu's theory (to be discussed in the next section of the present chapter), then the separation of powers made by Locke rests on an assumption that Montesquieu could not have made, namely that in extremity the body of the people will be a limitation on the omnipotence of both the legislative and the executive.

The problem with that limitation in Locke's theory is that the power of the people does not appear here in any institutionalised form; it is potential rather than actual and may not even manifest itself as long as representative government exists. In fact the people does not belong to the system of government, as it does not act in any systemic way. Even though it has the competencies of a constitutional court, it may not exact them in the political system. In everyday life, it is as mute as the consent it gives to the government, and only in special situations does Locke expect it, even obligate it, to speak out loud.

And where the Body of the People, or any single Man, is deprived of their Right, or is under the Exercise of a power without right, and have no Appeal on Earth, there they have a liberty to appeal to Heaven, whenever they judge the Cause of sufficient moment. And therefore, tho' the People cannot be Judge, so as to have by the Constitution of that Society any Superior power, to determine and give effective Sentence in the case; yet they have, by a Law antecendent and paramount to all positive Laws of men, reserv'd that ultimate Determination to themselves, which belongs to all Mankind, where there lies no Appeal on Earth, viz. to judge whether they have just Cause to make their Appeal to Heaven. And this Judgment they cannot part with, it being out of a Man's power so to submit himself to another, as to give him a liberty to destroy him; God and Nature never allowing a Man so to abandon himself, as to neglect his own preservation ${ }^{268}$.

Consequently, in the political system the people as a body appears only in times of crises, i.e. whenever the legislative, over which there is no other higher power, exceeds its mandate. Then the people can legitimately, and indeed should, remove it by force, for, having no legal devices to protect its life, 'the Appeal lies to God in Heaven ${ }^{269}$. Locke uses this biblical euphemism to denote the use

267 According to Laslett, Locke only repeats the widely held opinion that all power must not rest in the hands of a single individual; thus, there is no 'doctrine' of division of power in his theory; cf. Laslett, 'Introduction,' p. 119-120.

268 Locke, The Second Treatise, $\$ 168$, p. 379-380.

269 Cf. Locke, The Second Treatise, $\$ 21$, p. 282: 'Where there is no Judge on Earth, the Appeal lies to God in Heaven'. 
of violence. Thus an 'Appeal to God in Heaven' is not an act of the sovereign's power, but an expression of the desperation of the $\operatorname{ruled}^{270}$. God in Heaven, and only $\mathrm{He}$, will judge whether the people had the right to rise against the legitimate government. Characteristically, this is virtually the only opinion expressed in The Second Treatise which Locke supports with the authority of the Bible and ancient authors, opposing it to the arguments of contemporary advocates of absolutism ${ }^{271}$. The question of whether that appeal belongs to each one individually or only collectively, to the people as a whole, or to its part also, even to a minor part, remains open ${ }^{272}$.

Regardless of its historical context, Locke's doctrine is therefore something more than a modern version of the mediaeval doctrine of opposition to tyranny, for it also applies to representative government, accountable to the represented. The fact that a century after the Glorious Revolution it would be invoked by the American revolutionaries, who overthrew a government ruling without their consent, means little here as compared to its revolutionary potential: it is a justification for the overthrow, potentially, of any government that in the opinion of the author goes beyond its mandate: precisely for its overthrow rather than for a peaceful change. Are we therefore allowed to attribute to Locke the liberal belief that no government may be regarded by citizens as their own and that one accordingly needs to remain distrustful of any government?

The Second Treatise does not provide a clear answer in this case, but encourages one to pose an even more fundamental question: why did not the philosopher

270 James Tuly argues otherwise: the people is located within the system of government after all, for Locke understands by that term not only an organised group, but also its representative, and even each individual acting in self-defence; cf. Tuly, An Approach, p. 319. However, one can hardly regard rising against legal government as a systemic activity. Margaret Canovan undoubtedly puts it more aptly: 'In normal times the authority of an abstract collective people is in reserve, but in the moment of revolution (not something to which people are easily provoked) a mobilized people can emerge out of that background on to the public stage; a contingent movement of free individuals, but of individuals acting together as a body to generate power and exercise sovereignty'; Margaret Canovan, The People (Cambridge: Polity Press, 2005), p. 104.

271 Cf. Locke, The Second Treatise, \$235-421, p. 421-427.

272 Jacqueline Stevens has a different opinion on the matter and argues that invoking the heavens and the right to opposition are not the same after all; even though Locke does not deny to anybody the right to appeal to the heavens and to rely on their decrees, he grants the actual right to opposition (just as he grants the right to choose the form of government) not to individuals, but to a majority; cf. Stevens, The Reasonableness, p. $443-447$. 
attempt to find a strictly political solution to the problem of abuses of power? And, as Plamenatz rightly points out, can a government that cannot be recalled peacefully actually be said to rule with the consent of the ruled ${ }^{273}$ ? For politics, as a special human activity, is supposed to replace violence, since violence, as was said in the previous chapter, is reserved for preserving the commonwealth in situations when its very existence is threatened.

An appeal to Heaven is indeed an extreme situation, as it means a return to the state between the first and the second stages of the contract - not to the state of nature, but precisely to political society, devoid of institutions of power; for the parties to the contract have pledged to one another not to return to the state of nature any more: one leaves it once and for all, definitively. Only someone intending to institute absolute power necessarily wants to return to it, but in that case this is no longer a state of peaceful cooperation, but a state of war, re-bellum, as Locke puts it. Thus it is the government itself that is the rebel, rather than the people that holds it back ${ }^{274}$. The author of The Second Treatise further argues here that the people can distinguish between the government's accidental trespasses and its systematic and intentional activities; it will not exercise its right imprudently, as it harbours an outright aversion to changing old forms and is aware that invoking divine decrees may end in its captivity.

Whensoever therefore the Legislative shall transgress this fundamental Rule of Society; and either by Ambition, Fear, Folly or Corruption, endeavour to grasp themselves, or put into the hands of any other an Absolute Power over the Lives, Liberties, and estates of People; By this breach of Trust they forfeit the Power, the People had put into their hands, for quite contrary ends, and it devolves to the People, who have a Right to resume their original Liberty, and, by the Establishment of a new Legislative (such as they shall think fit) provide for their own Safety and Security, which is the end for which they are in Society ${ }^{275}$.

273 Cf. Plamenatz, Man and Society, I, p. 366.

274 Cf. Locke, The Second Treatise, $\$ 17$, p. 279: 'To be free from such force is the only security of my Preservation: and reason bids me to look on him, as an Enemy to my Preservation, who would take away that Freedom, which is the Fence to it: so that he who makes an attempt to enslave me, thereby puts himself into a State of War with me. He that in the State of Nature, would take away the Freedom, that belongs to any one in the State, must necessarily be supposed to have a design to take away every thing else, that Freedom being the Foundation of all the rest'; cf. $\$ 229-231$, p. 417-419.

275 Locke, The Second Treatise, $\$ 222$, p. 412-413. That is why, Tuly locates Locke’s liberty not in the liberal, but in the republican tradition, as opposed to Hobbes, and close to Machiavelli, even though he attributes to Locke scepticism about the republican 
One may say that no other possibility of solving the problem of abuses of power has been left to Locke than the one discussed above: once the body of the people has relinquished power, it can take it back exclusively by force. Jean-Jacques Rousseau understands it well and that is why he precludes any kind of representative government. Montesquieu, on the other hand, who takes representative government for granted, along with the fact that by its very nature it alienates itself, will see a solution to the problem in a mechanism for its division, one which goes beyond a differentiation of its functions, however. The limitation of Locke's representative government rests ultimately on his trust in the people, i.e. the community constituting the political commonwealth. Like a classical republican, Locke seems to believe that the body of the people has so much courage in it that, faced with oppression on the part of the government, it is ready to risk its life and well-being in order to make an attempt to overthrow it. Holding that belief, he actually does not have to establish the whole complex machinery of separation of powers, as the people will curb each of them. Paradoxically, Locke, the proper founder of the liberal tradition, seems to have been the last to share this republican belief ${ }^{276}$, as modern republicanism, to quote Albert Hirschman, will trust the solicitude for individual material interests more than collective passions. It is on those interests, and on them alone, that Montesquieu's idea of separation of powers is based.

\section{A power against a power - a party against a party: The Spirit of the Laws by Montesquieu}

Treasuring freedom above all the other political values, Montesquieu is aware that creating and preserving it within a state does not depend on the 'form' of that state, i.e. its constitutional solutions, but on the 'principle', i.e. complex circumstances: 'the spirit of the laws', making the institutions of public life act in

belief that the people could prevent the government from abuses of power; cf. Tuly, An Approach, p. 301, 318, 321.

276 Canovan arrives at a similar conclusion while attempting to explain the contradictory notions of 'the people' in Locke's theory (the people is interpreted either collectively or individualistically). In the opinion of that author, who voices a reservation that to those conversant with the philosophy of the author of The Second Treatise this interpretation will not seem convincing, Locke's notion of the social contract should not be associated with liberalism; cf. Canovan, The People, p. 100-104. 
one way and not another ${ }^{277}$. The form of government he presents, the 'specific' object of which is to preserve freedom (self-preservation is the universal aim of each form of government), is therefore the form of government of a particular people, living in favourable geographical circumstances.

Historians of ideas have not failed to note that Montesquieu attributed to British institutions principles that they were not actually guided by ${ }^{278}$. The matter may, however, be more complex, given that the author of The Spirit of the Laws uses the conditional to describe this phenomenon, or openly says how those institutions ought to function ${ }^{279}$. For this reason, it would be more reasonable to regard his description, even if it corresponds to historical realities to a certain extent, simply as an exposition of Montesquieu's own views: i.e. as a design of a form of government best protecting freedom.

In The Spirit of the Laws Montesquieu defines liberty in several ways, and one of those definitions directly invokes the sense of security of individuals:

Political liberty in a citizen is that tranquillity of spirit which comes from the opinion each one has of his security, and in order for him to have this liberty the government must be such that one citizen cannot fear another citizen ${ }^{280}$.

277 Despite his sympathising with the English form of government, formally a monarchy, Montesquieu is universally regarded as a founding father of modern republicanism (cf. Judith N. Shklar, 'Montesquieu and the New Republicanism').

278 Even so, Plamenatz believes that this analysis testifies to the author's profound understanding of what political power consists in (cf. Plamenatz, Man and Society, II, p. 42-45), and Lowenthal regards it as a classical 'noble lie': Montesquieu was aware that cabinet governments formed by a parliamentary majority are not in agreement with the separation of powers principle, but he did not even mention them, regarding them as harmful to the liberty of the citizens; thus, his vision of the form of government of England rather presents a certain 'logic of liberty'; cf. Lowenthal, 'Montesquieu, p. 524 .

279 This is also pointed out by Paul Rahe, who observes that Montesquieu uses that mode elsewhere only to describe the state of nature, thereby presenting potentiality rather than reality; however, the author does not elaborate on this subject; cf. Paul Rahe, Montesquieu and the Logic of Liberty (New Haven - London: Yale University Press, 2009), p. 54.

280 Charles Louis Montesquieu de Secondat, The Spirit of the Laws, trans. Anne M. Cohler, Basia S. Miller and Harold S. Stone (Cambridge - New York - New Rochelle Melbourne - Sydney: Cambridge University Press, 2002), Book 11, Chapter 6, p. 157. The most frequently quoted definition of liberty includes the following fragment: 'In a state, that is, in a society where there are laws, liberty can consist only in having the power to do what one should want to do and in no way being constrained to do what one should not want to do'; Book 11, Chapter 3, p. 155. 
In Book 11 of that work, there is no mention of liberty as it was supposedly practised in ancient republics; Montesquieu follows Hobbes here, though he does not go very far, as he indirectly introduces at the beginning of Book 12 a distinction between political liberty 'in its relation to the constitution' and 'in its relation to citizen', which the author of Leviathan would surely categorically reject. For Hobbes excludes the possibility that the category of liberty might in any way refer to a form of government, while Montesquieu, thanks to this distinction, may speak of liberty in the political and social dimensions, and at the same time of its political and social determinants ${ }^{281}$.

Only the disposition of the laws, and especially of the fundamental laws, forms liberty in its relation to the constitution. But, in the relation to the citizen, mores, manners, and received examples can give rise to it and certain civil laws can favor $\mathrm{it}^{282}$.

Thus, from Montesquieu's perspective, political philosophers, including Locke, oversimplify the problem of liberty in reducing it to the sphere of law (natural and codified), since limits of power, at least in non-despotic forms of government, are also defined by a given people's 'mores and manners'. But while liberty in the civil sphere may exist, in a manner of speaking, independently of the form of government, in the political sphere it will not survive without the support of those mores and manners; this is what is revealed by Montesquieu's analysis of the rule of a divided government representing a divided society.

Montesquieu justifies the necessity of separation of powers similarly to Locke: power concentrated in the hands of a single individual will by nature be despotic power, and this applies both to Turkey under the rule of an autocratic sultan, and to the Italian republics, where all power rests in the hands of many, but of the same people. States with a republican form of government, i.e. aristocracy and democracy, are not free by their very nature; they are free only if their governments are moderate, i.e. when they have been limited in one way or another. For Montesquieu regards it as certain that each government left without limitations poses a threat to the ruled. Reason may not teach this, but it has 'eternally been observed'.

Who would think it! Even virtue has need of limits. So that one cannot abuse power, power must check power by the arrangement of things ${ }^{283}$.

281 Paul Rahe writes more extensively on the subject in Montesquieu and the Logic of Liberty, p. 95-99.

282 Montesquieu, The Spirit, Book 12, Chapter 1, p. 187.

283 Montesquieu, The Spirit, Book 11, Chapter 4, p. 155. 
The functional separation of powers proposed by Montesquieu occurs according to Locke's well-known formula. The object of the legislative is to make general laws and 'to see if those they have made have been well executed'; by no means should the legislative body participate in the ruling process, because it is 'a thing it would not do well': this is the aim of the executive. By passing laws, the legislative cannot strictly follow the instructions of its electorate, for even if 'the word of the deputies would better express the voice of the nation', this could cause a practical paralysis of the legislative. On this occasion, Montesquieu once again recalls that the people cannot make laws, and its competences in this respect are limited to electing representatives; the great weakness of the ancient republics lay precisely in the fact that the people made laws directly in them ${ }^{284}$.

Thus, it is the hereditary nobility and the elected representatives of the people that are to sit on the legislative, but these two bodies are to debate separately. For within the legislative itself, a balance of interests should be maintained; if 'people who are distinguished by birth, wealth, or honors' had the same vote as others, 'the common liberty would be their enslavement ${ }^{285}$. For the citizens' liberty and, by the same token, their safety requires an institutionalised inequality.

A bicameral parliament is not a sufficient safeguard against the tyranny that the legislative could impose lege artis, however. While admittedly its two houses may remain balanced, they may also, given that each government tends by its very nature towards alienation, jointly abuse their mandate to the detriment of the ruled. And this is precisely what Montesquieu fears; even if the executive operates within the limits of the law enacted by the legislative and is subject to its review, who will review and hold off the legislative itself? This function can only be discharged by a strong executive.

Therefore, Montesquieu equips it not only with the right to convene and adjourn the legislative, and determine the time of its deliberations, but also to interfere outrightly with its competences, granting to the government 'the right to render null', or a legislative veto ${ }^{286}$. For even if the executive cannot directly influence the contents of the laws passed by the legislative, thanks to this competence, it gains a certain participation in the legislative power, limiting its 'faculty of enacting. Crucially, Montesquieu does not expect anything more from the

284 Cf. Montesquieu, The Spirit, Book 11, Chapter 6, p. 159-160, Book 2, Chapter 2, p. 11-12.

285 Montesquieu, The Spirit, Book 11, Chapter 6, p. 160.

286 Cf. Montesquieu, The Spirit, Book 11, Chapter 6, p. 161: 'I call the right to order by oneself, or to correct what has been ordered by another, the faculty of enacting. I call the right to render null a resolution taken by another the faculty of vetoing. 
executive than a defence of its own privileges; there is no talk here about any kind of acting on behalf of the citizens (see below). It will be the most effective when it is concentrated in the hands of a single individual, in royal hands. The legislative should not limit it except by means of codified law; 'execution has the limits of its own nature' and applies only to current, short-term concerns; it should, however, be able to examine how these laws are enforced ${ }^{287}$. Like Locke's prerogative, the mechanism of separation of powers presented by Montesquieu clearly strengthens the executive vis-à-vis the legislative.

How far can 'the right to render null' reach, however, so as not to paralyse the rule in a commonwealth, a situation so much feared by Hobbes? Will that not be tantamount to a state of diarchy, i.e., as the English philosopher believes, a state of potential or even actual war between the legislative and the executive? Montesquieu does not fear that state; the equal strength of both powers only leads to their rest or inaction. If some decisions actually have to be made, then 'by the necessary motion of things' ${ }^{288}$ the two powers will arrive at an agreement and make those decisions. Obviously, this kind of answer will not convince a political philosopher, but Montesquieu does not say this as a philosopher discovering simple and immutable principles behind the complexity of the world ${ }^{289}$, but as a sociologist identifying within that complexity that which is in the nature of the thing'.

However, can one accept Montesquieu's explanations, guided exclusively by his faith in the wonderful balance? As Pierre Manent notes, if, as Montesquieu assumes, the powers can come to an agreement to the benefit of the citizens, cannot they also collude to their detriment, considering that both face a risk of alienation $^{290}$ ? Whence will the 'right to render null a resolution' come in such a case? It is at this juncture that the idea of separation of powers is associated with the idea of representation in Montesquieu's philosophy. Owing to representation by political parties, society itself will ultimately be the guarantor of the balance of powers ${ }^{291}$. Montesquieu does not provide proof for that claim until Chapter 17

287 Cf. Montesquieu, The Spirit, Book 11, Chapter 6, p. 164.

288 Montesquieu, The Spirit, Book 11, Chapter 6, p. 164-165. In reconstructing Montesquieu's reasoning on this point, I largely rely on Pierre Manent's interpretation.

289 The author announces this as early as in the Preface: 'The sallies that seem to characterize present-day works will not be found here. As soon as matters are seen from a certain distance, such sallies vanish; they usually arise only because the mind attaches itself to a single point and forsakes all others'; Montesquieu, The Spirit, p. xliv.

290 Cf. Manent, An Intellectual, p. 58.

291 Thomas Pangle believes that it would be an abuse, however, to see in Montesquieu's thought an anticipation of the party system; in his opinion, Montesquieu, like the 
of Book 19 (hence the criticism concerning the chaotic character of his work), where he refers directly to his earlier considerations on the form of government in England.

Like that fragment, the Chapter 'How laws can contribute to forming the mores, manners, and character of a nation' is written partially in the conditional. It outlines a certain type of society - later called 'individualistic' by Alexis de Tocqueville - in which 'each citizen would have his own will and would value his independence according to his taste ${ }^{292}$. The citizens living in it turn out to be strikingly similar to the Hobbesian people in the state of nature, which is hardly surprising if one takes into account the criticism that Montesquieu puts forward against the author of Leviathan: that of civilised individuals, already living in society, as individuals in the state of nature. Meanwhile, the author of The Spirit of the Laws argues, it is only in society that rivalry between people appears, for it is then, under the protection of the law, that people lose the natural fear they harbour of one another in the state of nature. Living amongst others irrevocably changes human nature. 'As all the passions are free there, hatred, envy, jealousy, and the ardor for enriching and distinguishing oneself would appear to their full extent', Montesquieu argues, and he ends his argument in a statement that a classical republican would consider absurd: 'and if this were otherwise, the state would be like a man who, laid low by disease, has no passions because he has no strength $^{293}$.

Rivalry between citizens, their personal ambitions and their animosities do not weaken the commonwealth at all; on the contrary, they make it more vigorous $^{294}$. The cause of that rivalry is no longer ars dominandi, but materialistic greed. In a society of that kind, which Montesquieu himself calls commercial, the

founding fathers of the American republic, wrongly believes that the institutionalisation of politics would deprive it of its ideological dimension; cf. Pangle, Montesquieu's, p. 127.

292 Montesquieu, The Spirit, Book 19, Chapter 27, p. 325.

293 Montesquieu, The Spirit, Book 19, Chapter 27, p. 325.

294 'The misfortune of a republic', Montesquieu argues, 'is to be without intrigues, and this happens when the people have been corrupted by silver; they become cool, they grow fond of silver, and they are no longer fond of public affairs; without concern for the government or for what is proposed there, they quietly await their payments'; Montesquieu, The Spirit, Book 2, Chapter 2, p. 14. 
same passions that once led to wars and conquests, now refined and civilised by commerce, bring benefits to the commonwealth as a whole $e^{295}$.

In that kind of society, and in that kind of society alone, separated powers may function properly, as it is only in that society that parties may emerge which, unlike in ancient republics, do not ruin public life. Crucially, these parties will arise across the estate divisions, for individuals in that society are no longer restrained by estate laws, nor united by estate solidarity; thus, commercial society is as much diversified as it is homogenised ${ }^{296}$.

As the laws there would not be made for one individual more than another, each would regard himself as the monarch; the men in this nation would be confederates more than fellow citizens ${ }^{297}$.

Thus, according to Montesquieu, parties are nothing more than groups of citizens supporting one of the two powers: either the legislative or the executive (the judiciary is independent of the two and thus 'absent' from this structure). They back one of them, expecting to gain benefits from it, and rise against that one which may deprive them of those benefits in order to give them to its own advocates ${ }^{298}$. That is why, Montesquieu claims,

most people would have more affection for one of these powers than for the other, as the multitude is ordinarily not fair or sensible enough to have equal affection for both of them ${ }^{299}$.

That state of affairs would be permanent, because, as he argues further on, 'the hatred between the two parties would endure because it would always be powerless ${ }^{3} 300$.

It is only when the two parties are balanced that the powers are balanced, too: no party has a permanent advantage over the other and one cannot grind the other down with the forces of the power it supports. In accordance with their

295 A classic work on the subject is the aforementioned book by Albert O. Hirschman, The Passions and the Interests. Political Arguments for Capitalism before Its Triumph (Princeton: Princeton University Press, 1997). Montesquieu is its principal character.

296 Cf. Pangle, Montesquieu's, p. 130.

297 Montesquieu, The Spirit, Book 19, Chapter 27, p. 332.

298 Cf. Montesquieu, The Spirit, Book 19, Chapter 27, p. 325: 'And, as the executive power, which has all the posts at its disposal, could furnish great expectations but not fears, all those who would obtain something from it would be inclined to move to that side, and it could be attacked by all those who could expect nothing from it'.

299 Montesquieu, The Spirit, Book 19, Chapter 27, p. 325.

300 Montesquieu, The Spirit, Book 19, Chapter 27, p. 325. 
inclinations, people are by no means disposed favourably towards one another and would readily harm one another; however, as they do not have an opportunity to do so, they remain helpless; it is actually that helplessness, Manent argues, that is the guarantee of their safety ${ }^{301}$. By means of the relevant institutions - representation and the separation of powers - their private vices become, paradoxically, public virtues, on which the entire social order is founded. Bad people turn out to be good citizens.

The explanation of the phenomenon of the functioning of separated powers must therefore ultimately come down to identifying the conditions of the balance in an individualistic society. The argument presented by Montesquieu, examining that which is 'in the nature of the thing', must initially surprise one, however. For it is not an analysis of the social condition, power relations, or relations between power and interests (and even less of the actual social relations in 18th-century England), but rather a description of a special kind of social attitude, close to the people living in the Hobbesian state of nature.

As these parties are made up of free men, if one party gained too much, the effect of liberty would be to lower it while the citizens would come and raise the other party like hands rescuing the body. As each individual, always independent, would largely follow his own caprices and his fantasies, he would often change parties; he would abandon one and leave all his friends in order to bind himself to another in which he would find all his enemies; and often, in this nation, he could forget both the laws of friendship and those of hatred ${ }^{302}$.

Surprisingly, contemporary political sciences seem to confirm Montesquieu's brilliant intuition, noting and explaining post factum the unexpected defeats of ruling parties ${ }^{303}$. He himself does not explain, however, why citizens should change parties and deprive themselves of the benefits brought by oppressing the other and taking over the goods offered to them by the other power. The architects of the American constitution, to be discussed in the following part of the present chapter, understood Montesquieu's argument in such a way that they attributed to citizens the natural attitude of distrust of government, of any government, i.e. including the one that gives them various benefits today only to take them away tomorrow. The citizens do not trust the government because

301 Cf. Manent, An Intellectual, p. 60.

302 Montesquieu, The Spirit, Book 19, Chapter 27, p. 326.

303 In recent years, the most spectacular example was the defeat of Helmut Kohl's party shortly after the reunification of Germany but before the revelation of a corruption scandal in his party several years later. 
they know, or rather feel, that they have little control over it; thus, they do not want it to grow stronger at their expense. They will support the power that does not (yet) seem dangerous to them, that is able to stop the other one. One may say that fortunately the general public does not have enough justice or reason to love the two equally. By loving them equally, it would lose control over them, as the two would not keep each other in check. That is why, quite rightly, it nurtures both hopes and fears vis-à-vis each of them. Pierre Manent writes:

The 'double dealing' of citizens with power is inscribed in the logic of representation: from the moment that power is supposed to represent the citizen, the feeling of alienation grows along with the desire for identification. Thus such a regime produces a double impotence ${ }^{304}$.

Explaining the changeability of parties with that kind of interplay, one must not, however, attribute too much reflectiveness to the citizens. Overwhelmed with materialistic passions, will they really have enough imagination and prudence to, as Hayek put it, see 'the road to serfdom' in the road towards prosperity offered to them by the government? For Montesquieu himself only writes about their 'humors' and 'inclinations' and does not mention any rational calculations. For he seems to place greater trust in the citizen's peculiar instinct - an instinct one should be looking for as early as in the state of nature, presented in his work so vaguely and casually - than in reason, which yields human passions. Characteristically, in Montesquieu's vision, man lives in fear of other individuals before he becomes convinced of his own power as a result of interacting with other people; he wants not so much to dominate as not to be subject to somebody else's dominance ${ }^{305}$.

In this state, each feels himself inferior; he scarcely feels himself an equal. Such men would not seek to attack one another ${ }^{306}$.

Man cannot even be said to fear government in that state, for the very idea of government is then alien to him ${ }^{307}$. However, since the sense of power has its

304 Manent, An Intellectual, p. 60.

305 Montesquieu, Manent notes, does not address the question of legitimisation of power at all in that connection, for he could not derive the readiness to subjugate oneself to the will of another individual from the desire to live in peace. The doctrine of the separation of powers is made possible precisely by the fact that Montesquieu 'forgets' about its legitimisation, taking power for granted; cf. Manent, An Intellectual, p. 54-55.

306 Montesquieu, The Spirit, Book 1, Chapter 2, p. 6.

307 'The idea of empire and domination', Montesquieu writes further, 'is so complex and depends on so many other ideas, that it would not be the one they would first have'; Montesquieu, The Spirit, Book 1, Chapter 2, p. 6. 
source in social relations, the fear of the government may only arise from that instinctive and natural fear that has to be preserved in society so as to make it possible for the citizen, paradoxically, to preserve his liberty and feel safe ${ }^{308}$. Thus, an equilibrium must ultimately occur within man himself, too, between his natural and social instincts; he must defend himself against dominance on the part of others, and as a social being he himself wants to subjugate others to himself. That is why, thinking about the relationship between nature and civilisation like Rousseau rather than like Montesquieu, one may harbour fears as to whether 'by the necessary motion of things' in a civilised society this instinct will actually weaken to the degree that the clear benefits offered by the government will suppress it.

For a man to feel safe in a state, his natural and immutable human aversion to tyranny must encounter proper social conditions that will make him enter the 'double game' with the government. The natural sense of liberty must become institutionalised, like the changeable 'whims' and 'humours', shaped in social relations. Thus, the preservation of liberty in the state depends ultimately on the kind of society in which those reprehensible habits with beneficial consequences are shaped, for even with an identical 'form' of government, its 'principles' depend on the 'spirit of the laws' governing a given society. The architects or reformers of the state cannot change these 'principles' using legal measures alone, but must take them into consideration when they give it a constitutional form. The 18th-century Americans, both the social elites and the common people, had no doubt that Providence had already created appropriate conditions for them to complete Its work themselves and, guided by the new science of politics, build a polity in which they would live without fear of the government, fearing only God Himself.

\section{A balance of interests and a natural elite: The Federalist Papers}

Acknowledging his debt to the Europeans (including the ancients), and attributing to them the invention of the idea of representation ${ }^{309}$, Alexander Hamilton, one of the authors hiding behind the name of Publius, observes, not without pride, that the Americans will be the first ones to make actual use of it, i.e. to institutionalise it under completely new circumstances.

308 Shklar notes that the self-preservation instinct is, according to Montesquieu, absolutely independent of political laws under which the people live; cf. Shklar, Montesquieu, p. 74.

309 Hamilton, Madison and Jay, The Federalist, No. 14, p. 60. 
I mean the ENLARGEMENT of the ORBIT within which such systems are to revolve either in respect to the dimensions of a single State, or to the consolidation of several smaller States into one great confederacy $y^{310}$.

Thus, a completely new type of polity comes into being in the New World. 'The enlargement of the orbit' has two meanings here. On the one hand, it stands for a democratisation of the polity: for extending political rights to cover all adult men, and, on the other hand, for expanding that polity by founding a 'federal republic' along the same lines as the one presented by Montesquieu in Book 9 of his work The Spirit of the Laws. Thanks to the enlargement of the orbit, citizens gain a safeguard against abuses on the part of the ruling legislators both within the borders of their state and in the union as a whole, because the federal government and the state authorities provide mutual checks to each other ${ }^{311}$. Hamilton seems to share Montesquieu's belief that man has a certain instinct for liberty, but as that instinct cannot be trusted unreservedly, it should be somehow institutionalised in the constitution. He quotes the French thinker's arguments:

If a single member should attempt to usurp the supreme authority, he could not be supposed to have an equal authority and credit, in all the confederate states. Were he to have too great influence over one, this would alarm the rest. Were he to subdue a part, that which would still remain free might oppose him with forces, independent of those which he had usurped, and overpower him before he could be settled in his usurpation $^{312}$.

Unlike philosophers, the authors of the American Constitution create a state not 'in mind' only, but in institutions. It is in them that they place much greater confidence than in human nature, for they think of the latter in Hobbesian rather than in Montesquieu's terms ${ }^{313}$. Why, therefore, do they see a solution to the problem of citizens' safety in a democratisation of the polity, i.e. in granting access to power to an even greater number of 'ambitious' and 'rapacious' individuals? One may naturally point here to historical circumstances: the nascent polity almost had to be a democracy, but this is also what the internal logic of the system as a whole argued for. For by means of 'the enlargement of the orbit', all citizens are granted safety, not only those by whose inclusion that orbit is actually enlarged. This is explained by the tenth and most famous Federalist Paper, in which Madison discusses the phenomenon of 'factions', or conflicted political parties.

310 Hamilton, Madison and Jay, The Federalist, No. 9, p. 36.

311 Hamilton, Madison and Jay, The Federalist, No. 46, p. 230.

312 Hamilton, Madison and Jay, The Federalist, No. 9, p. 38.

313 Hamilton, Madison and Jay, The Federalist, No. 6, p. 19. 
Unlike Montesquieu, Madison does not argue that citizens, guided by a fear of the rulers, will change the authorities in order to retain a balance between them; what he does argue, on the other hand, is that the constitution itself created such conditions that none of the parties will become strong enough on the national scale to permanently dominate the legislative, i.e. to create a 'majority faction', a major group of citizens

who are united and actuated by some common impulse of passion, or of interest, adverse to the rights of other citizens, or to the permanent and aggregate interests of the community ${ }^{314}$.

Parties will naturally arise, for such is the nature of liberty; one may make either good use or bad use of this phenomenon; rather than taking the ability to form parties away from the citizens, one only needs to counteract the bad consequences this may entail. Thus, the political system must 'filter' the citizens' ideas without destroying them. Even if a majority of the people should become overwhelmed by some kind of detrimental passion, the political institutions must not allow the legislative to succumb to it as well.

In small republics, the occurrence of passions of this kind is nearly inevitable: there is too much that unites most of the citizens, and they are too similar to one another not to succumb to them. Thus, 'the enlargement of the orbit' reduces the risk of an emergence of a 'majority faction' that undertakes, with the sanction of the law which they themselves have made, a policy of discrimination against minorities. Madison follows up on the subject in Paper LI:

In the extended republic of the United States, and among the great variety of interests, parties and sects which it embraces, a coalition of a majority of the whole society could seldom take place on any other principles than those of justice and the general good ${ }^{315}$.

That is why, even though America may not be a commercial society to the same degree as England ${ }^{316}$, it meets Montesquieu's condition: a diversity of interests (as well as of religious denominations) imparts to a young democracy a decidedly individualistic character. As a society, it is too big for a major party to emerge, capable of dominating the representative body; for the members of such a potential majority would themselves, in other respects, belong to various minorities ${ }^{317}$.

314 Hamilton, Madison and Jay, The Federalist, No. 10, p. 41.

315 Hamilton, Madison and Jay, The Federalist, No. 51, p. 255.

316 Nonetheless, Hamilton argues that it is precisely commerce that defines its character; cf. Hamilton, Madison and Jay, The Federalist, No. 11, p. 46-47.

317 Hamilton, Madison, and Jay, The Federalist, No. 10, p. 45-46. 
This condition is only fulfilled by American society as a federal republic; the populations of particular states are indeed too homogenous for this.

Diversity in society will not, however, in itself safeguard it against tyranny, unless by means of institution of representation this diversity is transferred into the political system. However, the architects of the American republic intentionally did not want to reproduce it accurately in the legislative; the opponents of a federation - both those who opted for direct forms of democracy and those who admitted the institution of representation itself - were actually right in claiming that the representatives would not be 'the same' as those whom they would represent ${ }^{318}$. For they were not meant to represent their voters in the sense of re-presenting them in the representative body, for this would mean that they brought their emotions and passions into the political system. 'The enlargement of the orbit' prevents parties driven by those emotions and passions from influencing political decisions except through their representatives, and it is precisely owing to that that it is possible in society

to refine and enlarge the public views, by passing them through the medium of a chosen body of citizens, whose wisdom may best discern the true interest of their country, and whose patriotism and love of justice, will be least likely to sacrifice it to temporary or partial considerations ${ }^{319}$.

The size of representative bodies should be such as to prevent phenomena from occurring within them that make the government either dangerous or useless to the citizens. These bodies must be large enough not to become an instrument of hidden tyranny as a result of the 'scheming' of several of their members, but at the same time not big enough to cause a paralysis of government ${ }^{320}$.

In order not to pose a threat to the citizens, and to protect them from themselves, representative government should therefore meet two conditions: it must, obviously, be accountable to the represented (this function is fulfilled, in the first place, by the checks and balances mechanism), but it must also enjoy a certain amount of autonomy and retain a certain distance from those whom it represents. This is precisely what is guaranteed by the Constitution, which demarcates constituencies that are big enough. Representatives of smaller constituencies would have to further the interests of majority interest groups, without whose support they would not have been elected; in bigger constituencies, their election

318 Cf. Manin, The Principles, p. 129.

319 Hamilton, Madison and Jay, The Federalist, No. 10, p. 44.

320 Hamilton, Madison and Jay, The Federalist, No. 10, p. 44-45; No. 55, p. 269-270. 
depends on the support of several smaller groups, and that less direct dependence gives them more freedom in their future activities.

What is necessary here, however, Madison stresses, is a certain compromise between commitment to the benefit of local communities with clearly articulated interests and concern for national affairs. In constituencies that are too big, the representative will not even know enough about his voters, while in ones that are too small, he will be so bound by their concerns that nation-wide problems will not concern him at all. Here again, in Madison's opinion, a federal republic ensures an optimum solution, as it provides for a division of competences between the state legislatures and the federal legislature ${ }^{321}$. To the benefit of the represented, different people will deal with their various interests.

Ultimately, therefore, the kind of people who are elected to representative bodies depends on the size of the polity and the sizes of constituencies. In a small republic, with small constituencies, a representative system of government will only cause a group of citizens that is a mirror image of the society to take the affairs of the polity into their own hands. It is only in large polities that representatives will become a natural ruling aristocracy, because, as Bernard Manin observes, they are the chosen in two senses: they owe their office to being elected, and they had been selected for that office ${ }^{322}$. Madison himself concludes that since

each Representative will be chosen by a greater number of citizens in the large than in the small Republic, it will be more difficult for unworthy candidates to practise with success the vicious arts, by which elections are too often carried; and the suffrages of the people being more free, will be more likely to centre on men who possess the most attractive merit, and the most diffusive and established characters ${ }^{323}$.

Characteristically, Madison pays more attention to the things that this kind of procedure safeguards against, rather than to the things that can be gained owing to it; the election of the 'men who possess the most attractive merit' is only probable; what is almost certain is keeping away from government people 'of factious tempers', alleged friends of the people. For all their reservations as to the competences of the so-called common people, the architects of the American republic have no doubt that, if only proper conditions are created, those people can elect a ruling elite for themselves. However, that elite, representing the people

321 Hamilton, Madison and Jay, The Federalist, No. 10, p. 45.

322 This author rightly points out that the Federalist has thus succeeded in smuggling the ancient idea of an elite into the system without mentioning it even once; cf. Manin, The Principles, p. 131.

323 Hamilton, Madison and Jay, The Federalist, No. 10, p. 45. 
in the institutions of power, will not be in any way representative of it; in fact, the entire political system is designed to protect the polity against the rulers being 'the same' as the ruled. They are to be ultimately defended against the passions common to all people by the impassionate institutions for the selection of the rulers.

\section{Representation and limited government: instincts and institutions}

Locke and Montesquieu, and the American federalists following in their footsteps, want to use the institution of representation to limit the power, the power to which Hobbes, invoking the idea of representation, imparted an absolute character. If people are to enjoy safety in a state, the power must remain within political society. The rulers must not rule over the heads of the ruled; power is to be exercised by their consent, it must not be concentrated in the hands of any one person, and a mechanism of mutual checks between the legislative and the executive must be integrated into its institutions. All these ideas are enshrined in the articles of the American Constitution, but in such a special way as to meet the declared goal by virtue of those institutions themselves; relying on imperfect human nature must have seemed too risky to the architects of the new polity, all the more so that in Locke's and Montesquieu's theories, expectations vis-à-vis people are, against all appearances, by no means small.

The image of threats to the liberty of the citizens that emerges from The Second Treatise is by no means unambiguous, even though this work was written in the period preceding the Glorious Revolution against the House of Stuart. For Locke does not anticipate that notorious law-breaking by a king exercising executive power should threaten the citizens' safety the most. He even has so much confidence in that executive that he grants to it special rights in the form of a prerogative, allowing it in an emergency to act outside the pale of the law made by the legislative. By virtue of the prerogative, the strengths of both powers are made almost equal. The executive, provided that it works towards the common good, is representative in the same degree as the legislative, which, even though in Locke's rhetoric it occurs clad in a nimbus of sanctity, is by no means immune to corrupt practices.

That is precisely why it is the people itself that is the ultimate guarantor of liberty in the polity - the same peoplewho, having no other possibility of influencing the government elected by itself, must in defence of liberty and security 'appeal to Heaven', i.e. rise in arms against the government. For Locke did not in any way institutionalise the control of the 'author', i.e. political society, over 
its representative, i.e. the government; in a political system the people is present exclusively through its representatives. That is why when the elected representatives 'change the Legislative', i.e. exceed their mandate, just as the executive does when it acts in contravention of the existing law, the people is as helpless as the subjects of the Hobbesian sovereign (all they can do is invoke natural law; what this means, however, is that they take away from the government its right to judge and punish legally, granted to it at the second stage of the social contract). The people does not resort to these rights unless the government is no longer its representation, but rather a usurpation.

Nor would Locke want the people to exert greater influence on the government when the latter observes the mandate entrusted to it. The government is the people's trustee and as long as it enjoys the people's trust, it does not need to be permanently controlled by the people. The solution presented by Rousseau in his Social Contract - the sovereignty of the people institutionalised in its regular meetings, in the course of which it decides on the preservation of the political system and the extension of the mandate of individuals wielding power - is simply unthinkable in Locke's commonwealth. The people in fact does not perform the role of the sovereign as defined by Hobbes and Rousseau himself, i.e. it does not make laws.

Locke's government ultimately gains legitimacy through the tacit consent of each of the ruled, to whom it guarantees security, while in Rousseau's republic, to be discussed in the following chapter, this consent has to be voiced expressly and aloud, and in Hobbes' commonwealth, as was said in the previous chapter, there is no place for it at all. Thus, Locke wants to ensure the safety of the ruled from the rulers, depriving the rulers of the control that the authors may exercise over their representatives, and on this particular point, he resembles Hobbes. Locke, the liberal, sets up a government as powerful as that set up by Hobbes, the autocrat, even though it is limited and removable just as the mediaeval tyranny was removable.

Even if Rousseau's solution makes an 'appeal to Heaven' as superfluous as unfeasible (the sovereign people is not bound by any natural laws), to Locke it is inadmissible because of the risk it would pose to the stability of the commonwealth, i.e. to the security of the citizens. For in his theory, each meeting of the Sovereign would be a return to the situation between the first and the second stage of the contract, when all power rests in the hands of political society, but it has no effective institutions, such as a confederacy of the citizens, to preserve a lasting peace. It is not an accident that Locke reiterates that the people has too much common sense to recklessly reject the benefits deriving from the existence of government. Locke does not exempt the people from the duty of republican vigilance, so to speak; 
for a representative government elected by the people does not cease to be government, and by the same token a source of threat. The republican people is supposed to be a guarantor of the liberal principle of limitation of the government.

This is what Montesquieu understands perfectly well, and that is why, he attributes to each government, regardless of its source and its scope of activity, a tendency towards alienation. Moreover, he sees the greatest threat to the citizens' security in the legislative, because even though it comes from society itself, it has greater possibilities of harming the citizens by making bad laws than the executive, which only enforces them. However, none of the powers has strength of its own; each derives all of it from the party standing behind it. That is why what is hidden behind the balance between the legislative and the executive - the balance being the condition for a limitation of those powers - is a balance in society, but - and this is a historical novelty - it is not permanent through the strength of the divisions existing in society, but rather it permanently reinstates itself by virtue of its individualistic character.

It arises, Montesquieu argues, owing to the fact that the relationship of representation establishes itself and continues exclusively due to self-interest. People social and asocial individuals at the same time - are not loyal to one another, so they will not be loyal to any government, either; they will abandon each one if that benefits them. Disloyalty is not a virtue, naturally, but it proves to be useful to the public, because it makes it possible to 'forget both the laws of friendship and those of hatred'324. Yesterday's enemies become tomorrow's friends, and, unlike the ancient republics and mediaeval city communes, contemporary society is not stuck in a clinch of two parties fighting a life-or-death battle. Against the wisdom of the centuries, Montesquieu thus teaches that concord ruins and discord builds.

Fortunately, neither do modern men possess that ancient virtue that would make them love the government of their own polity just because it is their polity. If they loved both powers in concord, those two powers would deprive them in concord of their liberty and security. The ruled have an equal interest in supporting one or the other; as none of them is their own, they can abandon each to support the other. For even the greedy bourgeois in a society dominated by commerce retain their natural fear of dominance by other people; in order to avoid an enslavement by the government, man will sacrifice the benefits that it offers him in the short term. He only supports it because of the benefits; the fear that the power provokes derives from its very essence. Montesquieu's man,

324 Montesquieu, The Spirit, Book 19, Chapter 27, p. 326. 
but each one separately, as an individual - a liberal individual, one could say - is therefore equipped with an instinct, similar to that which Locke granted collectively to the people. If, however, in The Second Treatise that instinct merely complements institutions of representation as the last instance of defence against tyranny, the institutions described in The Spirit of the Laws may function properly only, thanks to the fact that that instinct does not fail the citizens on a daily basis.

In the Federalist Papers, power itself does not appear as a threat any more; it only becomes a threat to the citizens when it has become dominated by a majority faction, i.e. a large group of people united by a common goal. In a civilised society, there is no people as such any more, there are only people: individuals taking advantage of their supremacy like an ancient people, having gained strength by their sheer numbers. That is why, any permanent majority whose capacity for action has not been limited in one way or another represents a threat to the security of the citizens. Thus the Federalists limit not so much its power as the possibilities of it being used by people, for they do not find in human nature an instinct of liberty - preferring security to ars dominandi - such as that attributed to them by Montesquieu. While designing a new polity, the architects of the constitution must replace that instinct with appropriate institutions, in which there will occur a complex interplay of social interests.

The newly emerged polity is to be a democratic republic not only in the institutional, but also in the normative sense. It is a democracy, for it is ultimately ruled by a majority rather than by a minority; it is a republic, for it has a president rather than a monarch at its helm. But it is also a democracy, for it allows all interests to be articulated, and at the same time a republic, for representatives of those interests by no means negotiate them between themselves, but rather deliberate on the common good of the whole polity. Representation here is about more than a mere 'filter' of interests; democracy without representation would bring a tyranny of the majority faction, while a republic without representation would consolidate the dominance of higher social classes.

That is why, only the institutionalisation of the idea of representation in an individualistic society fully reveals its paradox with reference to a limitation of power as a condition of the citizens' security. For, unlike in a mediaeval feudal state, it turns out to be a kind of by-product of the representative system. Citizens elect their representatives so that they promote their interests, but through the channels of political representation they may do so only to a limited extent; well-designed institutions of representation confront various interests with one another and keep them balanced. One may therefore say that, paradoxically, safety is what the citizen receives collectively from a balanced political system, 
and not individually from his representatives, to compensate, as it were, for what he cannot gain, i.e. a full securing of his private interests.

What representation stands for here is the distance that the rulers gain vis-àvis the ruled in order to 'ennoble' the interests represented, i.e. to deprive them of a narrow particularism. People place their trust in those who are supposed to look after their well-being; institutions of the political system, on the other hand, in their own way make these representatives care for the well-being of the state as a whole. Thus, the complexity and peculiarity of that legitimisation formula consists in the fact that the representative character of the government justifies both private and public interests. Accordingly, government in a democratic republic, as presented by the Federalists, is legitimised not only by the modern will of the ruled, but also by the ancient knowledge of the philosopher king; representation is a iunctim between them. The following chapter elaborates on this subject. 



\section{Representation and the common good}

\section{The common good and the procedures for defining it}

Listing six reasons why people, unlike bees or ants, e.g., are unable to live in peace, Thomas Hobbes draws directly on the idea of the common good. While to animals living in a community, claims the author of Leviathan, the private good is by virtue of their instinct the same as the public good, man, endowed with reason, clearly separates the two, to his own detriment. Hobbes sums up his argument as follows:

Lastly, the agreement of these creatures is Naturall; that of men, is by Covenant only, which is Artificiall: and therefore it is no wonder if there be somwhat else required (besides Covenant) to make their Agreement constant and lasting; which is a Common Power, to keep them in awe, and to direct their actions to the Common Benefit ${ }^{325}$.

Only a power, representing each individual's desire to survive, may guarantee that, for it is only a power, irrespective of the form of government wielding it, that strives towards the common benefit. After a commonwealth is founded, human nature does not change; thus, the only thing for the people to do is to subordinate themselves to that power and not lend their ears to misleading doctrines that expose it as a usurpation. As the common good cannot be derived from human nature or from the authority of the Word of God (how widely do its interpretations differ!), the power itself has to decide in what the common benefit lies. Hobbes thus rejects the substantive concept of the common good, placing a government decision in its stead. Ultimately, he drives modern political thought towards seeking a procedure for defining it, for a government ruling by the consent of the ruled cannot allow Leviathan to act arbitrarily.

By its very nature, the character of representative government does not impose any single method of defining the common good; even less can it be said to follow from the theory of Hobbes, who was very far from binding the sovereign with any rules for decision-making. Only the Aristotelian tradition rejected by the English philosopher associates those rules with deliberation, a public debate of equal and free citizens, idealised by Aristotle in his Politics ${ }^{326}$. Accordingly, it is deliberation that has first to be adapted as a procedure by which the representative body

325 Hobbes, Leviathan, Chapter XVII, p. 120.

326 On the concept of the common good in Aristotle's thought see Paweł Spiewak, $W$ stronę dobra wspólnego (Warszawa: Wydawnictwo Aletheia, 2005), Chapter IV, p. 93-128. 
arrives at decisions. Contrary to it, the idea of aggregation, i.e. summing up, or more precisely deriving the common good from the individual goods of particular citizens, will only appear together with an advancing democratisation of the state, i.e. with expanding the civic community ${ }^{327}$. Which of these procedures is more consistent with representative government? Is representative government a government debating on what is common to the represented, or only one summing up what makes them different? Edmund Burke's, Jean-Jacques Rousseau's and John Stuart Mill's views on representation discussed in this chapter illustrate this particular controversy.

Edmund Burke was not a political philosopher like Hobbes or Rousseau. He was a philosophising politician, who for most of his adult life sat in the House of Commons; Burke called himself 'the philosopher in action ${ }^{328}$, declaring that subtle speculations and theoretical distinctions were alien to him, while welltested principles of pursuing politics were dear to his heart ${ }^{329}$. His 'Speech to the Electors of Bristol on Being Elected', explaining how he understood his role as a member of parliament, is his most important (and most often cited) lecture on representation, but not the only one. Also important are his Reflections on the Revolution in France, parliamentary speeches on the American colonies and the East India Company, and in particular his Thoughts on the Cause of the Present Discontents of 1770 . What emerges from them is a concept of a political system set in the British realities, the essence of which is deliberation of representatives

327 Thus, the common good is interpreted more broadly here than in the classical republican tradition, in which it is not reducible to individual goods. In modern political philosophy, this idea actually appears under various terms, most importantly 'public interest' and 'common interest'; for more on the subject, see Robert A. Dahl, Democracy and Its Critics (New Haven: Yale University Press, 1989), most importantly Chapter XXI: The Common Good as Process and Substance.

328 Cf. Edmund Burke, 'Thoughts on the Cause of the Present Discontents', in: PreRevolutionary Writings (Cambridge: Cambridge University Press, 1993), p. 187. Perhaps because of that inclination he was considered too restless and unpredictable a mind in his party; he was not trusted or given any important functions; cf. Harvey C. Mansfield, 'Edmund Burke', in: History of Political Philosophy, ed. Strauss, Cropsey, p. 687-688.

329 Cf. Edmund Burke, 'On American Taxation,' in: Edmund Burke on Government, Politics and Society, ed. Brian W. Hill (New York: International Publications Service, 1976), p. 150; the question of how far Burke was guided in politics by his declared principles is discussed more extensively by Tomasz Merta; see Tomasz Merta, 'Roztropność Edmunda Burke’a', in: Nieodzowność konserwatyzmu. Pisma wybrane (Warszawa: Teologia Polityczna, Muzeum Historii Polski, 2011). 
of the entire nation on its common good, as opposed to aggregation, in any case aggregation in the form in which it was practised by the National Assembly of revolutionary France. Rousseau, on his part, is a confirmed critic of that form of representation which is extolled by Burke, because he is strongly opposed to both representation and deliberation, no matter who takes part in it. In his Considerations on the Government of Poland ${ }^{330}$, written ten years after the publication of The Social Contract, he permits representation in a peculiar form, however ${ }^{331}$, without specifying, incidentally, what the deliberations of the general diet (made up of delegates of the provincial dietines) consist in. Is this the philosopher's concession to the historical circumstances? In his plan for a fundamental reform of Poland's political system, Rousseau had to take them into account ${ }^{332}$, while in his flagship work there is not even a trace of them. However, one must not exaggerate the difference between these two treatises; on many occasions the author refers the reader to The Social Contract to find there an

330 Rousseau was commissioned to write this work by count Michał Wielhorski, a member of the Bar confederacy who represented it abroad, on the basis of interviews with the count and materials he provided on the history and form of government in Poland. Some commentators believe that Rousseau, who usually had an encyclopaedic knowledge of the subject of his treatises, in this case rightly excuses himself that he does not know too much about it; cf. Willmoore Kendall, 'How to Read Rousseau's "Government of Poland", in: Jean-Jacques Rousseau, The Government of Poland (Indianapolis: Hacket Publishing Company, 1985), p. IX-XII.

331 Richard Fralin, who devoted an entire book to the problem of representation in Rousseau's thought, argues that he changed his opinion on the subject, from passive approval in A Discourse on Political Economy, through its radical criticism in The Social Contract and moderate criticism in the Lettres écrites de la montagne, to its conditional approval in his Considerations on the Government of Poland; cf. Richard Fralin, Rousseau and Representation. A Study of the Development of His Concept of Political Institutions (New York: Columbia University Press, 1978).

332 This is even true of matters as fundamental as the status of townspeople, and in particular of the peasants who remain in serfdom; arguing for the need to grant them civil rights, Rousseau admits nevertheless that they are not 'capable of tolerating' freedom at the moment; he also hesitates as to whether to grant civil rights to nonproperty-holders, for they can only be the clientele of the wealthy; cf. Jean-Jacques Rousseau, 'Considerations on the Government of Poland,' in: The Social Contract and Other Later Political Writings, ed. Victor Gourevitch (Cambridge: Cambridge University Press, 1997), p. 197, 223. Despite these compromises made by Rousseau, Kendall believes that the case of Poland actually allowed him to present the perfect form of government for every large state (which naturally increases the importance of the treatise itself); cf. Kendall, 'How to Read Rousseau's, p. XXVII-XXXVII. 
elaboration on an idea briefly presented in the Considerations. Is Burke therefore right to accuse him of extending intellectual patronage to the concept of the common good as a mere sum of the goods of departments, mechanically demarcated by a doctrinaire government? In fact Rousseau is also an opponent, as a matter of principle, of a concept of representation that reduces the common good to an aggregate of particular goods.

John Stuart Mill published his treatise Considerations on Representative Government in 1861, almost precisely a hundred years after the publication of Rousseau's Social Contract ${ }^{333}$. In the United Kingdom, where the institution of representation first served the purpose of limiting royal power, subsequently leading to rule by the victorious party, the process of democratisation had been taking place for over twenty years. Mill, even though he believes in progress and looks with optimism into the future, has no doubt that an enlightened tyranny or, in the case of colonised nations, the guardianship of an enlightened European nation, still suits most nations better. Harbouring a sincere aversion to nationalist sentiments, he believes, moreover, that the only solution that remains to enlightened but ethnically diverse societies is a federation with separate institutions of representation for each of its peoples ${ }^{334}$.

His representative government project, the best possible form of government, is therefore both universal and historical; it is an ideal system of government for a certain type of society. And precisely because it is the government that is largely responsible for the enlightenment of peoples and nations, the procedure for defining the common good of a society ripe for representative government must include both an element of deliberation and of aggregation. The political system designed by Mill cannot be said to institutionalise either of these two principles, however. It ultimately serves the purpose of including the intellectual

333 One has to note that today the term 'representative government' may be misleading in that it need not be representative of society, i.e. reflecting social diversity.

334 Cf. John Stuart Mill, Considerations on Representative Government (Cambridge: Cambridge University Press, 2010), p. 296; cf. also p. 305-319. Characteristically, Mill does not mention any other important social divisions, economic or religious, in this context. Graeme C. Duncan believes that Mill, even though he does not share Comte's opinion on the inevitable homogenisation of societies, nevertheless hopes that these divisions will not be deep in the future; cf. Graeme C. Duncan, Marx and Mill: Two Views of Social Conflict and Social Harmony (Cambridge - London - New York - Melbourne: Cambridge University Press, 1973), p. 276-278. 
elite, because it is that elite that should ultimately decide in what the common good of society as a whole consists.

\section{Deliberation of the representatives of the nation: 'Speech to the Electors of Bristol on Being Elected' by Edmund Burke}

The philosophy of Burke, a founding father of modern conservatism, has its starting point as much in his respect and admiration for the English political system as in the Aristotelian ontology of the social world; accordingly, his drawing on the idea of deliberation is not an accident ${ }^{335}$. Like Aristotle, Burke does not ask the question about the origins of power at all, but criticises the theory which regards the social contract as the only source of legitimate power, or at least the version of this theory propagated by the revolutionary French ideology. That theory, maintains Burke, is simply untrue, and at the same time extremely harmful, given that according to it all the current governments must be deemed illegitimate ${ }^{336}$; even if the subjects' consent was directly expressed at any time, this occurred so long ago that that founding act does not legitimise any of the existing governments ${ }^{337}$.

It is time that legitimises government; its recognition by the ruled as legitimate is ultimately founded on 'usucaption'338. Burke does not elaborate on this metaphor, only explaining to the French, though actually more to the English, that the dynasty ruling his country has integrated itself with the society over the centuries, which is more than can be said of revolutionary government, based on metaphysical abstractions and exacting obedience with terror and violence ${ }^{339}$.

335 Obviously, Burke cannot be said to pursue political theory in an Aristotelian manner, as he discredits metaphysics (cf. Strauss, Natural Right and History, p. 311-312); one must not forget, however, that the anti-metaphysical edge of his argument is directed not against Aristotle, but against Rousseau. Burke does not completely reject social theory; he only imparts to it a conservative character; for more on the subject, see Krzysztof Pieliński, Konserwatyzm jako oswajanie chaosu świata empirycznego (przypadek Edmunda Burke’a) (Warszawa: Elipsa, 1993), p. 59.

336 Cf. Edmund Burke, 'Reflections on the Revolution in France', in: Revolutionary Writings (Cambridge: Cambridge University Press, 2014), p. 57-58. Such a conclusion may be drawn from the first paragraph of Rousseau's Social Contract.

337 Burke, 'Reflections', p. 15.

338 Leo Strauss explains this, in the spirit of Locke, as a passivity of the silent majority; cf. Strauss, Natural Right, p. 304.

339 Cf. Burke, 'Reflections,' p. 28. Burke wrote these words in 1790, which benevolent interpreters regard as evidence of his amazing perceptiveness. 
Government discharges such a crucial function in society, or rather for society, that its change, though not its reform, is a last resort. Assessing the causes of conflicts between the rulers and the ruled, Burke has accordingly a great deal of sympathy for the arguments put forward by the government; even if people are often rightly concerned about the way public affairs are unfolding, they usually explain the causes of disturbances incorrectly and that is why they wrongly blame the government for them ${ }^{340}$.

In agreement with Hobbes, and contrary to Aristotle, Burke sees government as a remedy to the innate weaknesses of human nature. Human nature is corrupt, even evil; someone or something has to rein in the passions intrinsic to $\mathrm{it}^{341}$. Consequently, the government will sometimes rule against the will of the ruled, but in their interests, properly interpreted: in the interest of the people as members of civil society ${ }^{342}$. It is only in civil society (in the sense given to that term by Locke) that they can enjoy their rights, but society itself also needs to be protected. Lacking any support whatsoever in human nature, it is something very fragile and artificial, protected merely by 'conventions', whose guardian is ultimately none other than the government ${ }^{343}$.

To Burke therefore each government, with the exception of a tyranny, is representative in the broad sense of the term, for its raison dêtre is always the good of the ruled; even if he has not been elected by his subjects, the ruler is not a usurper. Burke argues as follows:

The king is the representative of the people; so are the lords; so are the judges. They are all trustees for the people; as well as the Commons; because no power is given for the sole sake of the holder; and although government certainly is an institution of Divine authority, yet its forms, and the persons who administer it, all originate from the people ${ }^{344}$.

340 Cf. Burke, 'Thoughts on the Cause,' p. 121.

341 Cf. Burke, 'Reflections', p. 60-61.

342 Cf. Edmund Burke, 'Tracts on the Laws against Popery in Ireland', in: The Political Philosophy of Edmund Burke, ed. Iain Hampsher-Monk (London - New York: Longman, 1987), p. 75.

343 Cf. Burke, 'Reflections,' p. 60.

344 Burke, 'Thoughts on the Cause,' p. 160. Frederick A. Dreyer believes the origins of political society to be the most puzzling issue in Burke's political theory: he sometimes stresses the divine and sometimes the human origins of power; for more on contradictions in Burke's views on the beginnings of the state, see Frederick A. Dreyer, Burke's Politics. A Study in Whig Orthodoxy (Waterloo, Ont.: Wilfrid Laurier University Press, 1979), p. 37-53. 
That is why, one needs to think of the House of Commons as an institution situated in the whole system of government, a point that those who absolutely demand a broader parliamentary representation fail to appreciate. It is not an organ of the supreme power. The unwritten English constitution, i.e. a collection of laws passed by the parliament, or rather their unique spirit ${ }^{345}$, ensures a balance of powers: the king, the House of Lords and the House of Commons; sovereign power is exercised jointly by the monarch and the parliament ${ }^{346}$. Parliament, even though it originally only performed a controlling function vis-à-vis the government, should therefore be merely a co-ruling institution. It should, as Burke puts it, be an intermediary between the people and the government; it must not unconditionally support the government or yield to the people's pressure ${ }^{347}$ : it must preserve an institutional autonomy. Ultimately, it is the representative body of the people that is the guardian of liberty, no matter against whom it were to defend it, even against the people itself $f^{348}$. That goal is to be served by reforms of that institution proposed by Burke, such as granting the vote to new interests and the introduction of permanent, continuous sessions ${ }^{349}$.

That is why, Burke resolutely and openly supports the cause of the Americans in Westminster. He argues that by denying them the right to representation, British governments question the very rules they are guided by themselves; for the colonists had brought the 'no taxation without representation' principle from

345 On what Burke understands by the English constitution, see John G. A. Pocock, 'Burke and the Ancient Constitution - A Problem in the History of Ideas', The Historical Journal, No. 2 (1960); Romuald Rydz, Edmund Burke na ścieżkach wolności (Poznań: Wydawnictwo Poznańskie, 2005), p. 153-160.

346 In Burke's time, however, the balance of powers was becoming a fiction and giving way to the practice of cabinet government, a fact that he did realise; he recalls it in an address informally commenting on a speech from the throne; cf. Edmund Burke, 'A Representation to His Majesty', in: Edmund Burke on Government, ed. Hill, p. 257, 260-261.

347 Cf. Burke, 'Thoughts on the Cause,' p. 159. Invoking 'Thoughts on the Cause of the Present Discontents, C.B. MacPherson observes that what Burke understands by 'the people' are landowners from the gentry and the bourgeoisie, capable of opposing the king; in one of his letters he estimates their number to be about 400,000; cf. Crawford B. MacPherson, Burke (Oxford - Toronto - Melbourne: Oxford University Press, 1980), p. 23-24.

348 Cf. Burke, 'Thoughts on the Cause', p. 181-182.

349 Burke writes of those reforms also in his 1780 speech on economic reform, in a freemarket spirit; cf. Edmund Burke, 'Speech on Economical Reform, in: The Political Philosophy, ed. Hampsher-Monk, p. 132. 
their old country ${ }^{350}$. If the colonies cannot be ruled according to constitutional principles, one should allow them to govern themselves; if this is done, even after their secession they will maintain friendly relations with their former metropolis. Burke also cites a pragmatic argument: it is not possible to rule so distant a people ${ }^{351}$; the British Empire can only be a commonwealth of nations, ruled with proper consideration being given to those nations' distinct interests, as expressed by their own representative assemblies, as well as - speaking in present-day language - with due respect to their cultural separateness ${ }^{352}$.

Burke does not tell the residents of Bristol about all this when seeking re-election, however ${ }^{353}$; he only presents them his own view on the relationship that should connect the voters with their representatives in parliament. His speech is not long, but very much to the point and free from the usual flattery. Burke begins by stating that even though he should, of course, take the voters' opinions and expectations into consideration, and put their interest before his own, what he owes them in the first place is an impartial assessment of public affairs. But government and legislation, Burke argues,

are matters of reason and judgment, and not of inclination; and what sort of reason is that, in which the determination precedes the discussion; in which one set of men deliberate, and another decide; and where those who form the conclusion are perhaps three hundred miles distant from those who hear the arguments ${ }^{354}$ ?

The voters have the right to present their own opinions to their representatives and to expect them to be taken into consideration; they cannot demand of their delegates, however, that they regard these as straightforward instructions in their parliamentary work. For this would be contrary to the customary law of the land and its unwritten constitution. Parliament, Burke argues in what is probably the most frequently quoted excerpt from this speech, is not a congress of ambassadors from different and hostile interests, with each one pursuing, like an advocate, his client's interests against all the others. Parliamentary politics must

350 Cf. Edmund Burke, 'Speech on Conciliation with America,' in: The Political Philosophy, ed. Hampsher-Monk, p. 120.

351 Cf. Burke, 'Speech on Conciliation with America,' p. 118.

352 Cf. Burke, 'Speech on Conciliation with America,' p. 112; Edmund Burke, 'A Letter to the Sheriffs of Bristol', in: Edmund Burke on Government, ed. Hill, p. 152, 197-198.

353 Burke won a seat in that election and, contrary to popular belief, he did not lose in the following one, but withdrew his candidacy; cf. Eulau, 'Changing Views of Representation,' p. 74.

354 Edmund Burke, 'Speech to the Electors of Bristol on Being Elected' (Nov. 1774) in: The Political Philosophy, ed. Hampsher-Monk, p. 109-110. 
not resemble negotiations, because all representatives have a common interest, no matter where they were elected. For parliament

is a deliberative assembly of one nation, with one interest, that of the whole; where, not local purposes, not local prejudices, ought to guide, but the general good, resulting from the general reason of the whole ${ }^{355}$.

The rich city of Bristol is only part of a great nation, having various interests, and the nation as a whole is part of an empire, even more diversified in that respect; all those interests have to be taken into consideration by a government ruling in the interest of the whole. A government not only represents interests; it is also under obligation to preserve the liberties the country has inherited from its ancestors as well as its constitution. A representative of any part of the country must not forget that he has obligations both vis-à-vis his electorate and vis-à-vis entire generations of his nation: the past, the present and the future ones.

This does not mean, however, that Burke expects complete freedom in parliament, or that he would consider any form of control on the part of the voters unacceptable ${ }^{356}$. Even though he believes trust between the rulers and the ruled to be absolutely necessary, the representatives of the people, just as their collective body, may not enjoy full trust of the voters, for if they have it they will abuse it. Paradoxically, their dependence on their voters gives them strength visà-vis the king and allows them to limit his power ${ }^{357}$. However, this dependence is most effectively necessitated by the institution of direct suffrage itself (i.e., before each election, every member of parliament seeking re-election will have to give an account of his activities to date), but not by direct control, and even less by detailed instructions. The voters exert an indirect influence on their representative: ' $\mathrm{t}$ ] here is no way to make a connection between the original constituent and the representative, but by the circuitous means ${ }^{358}$, and it is only that kind of

355 Burke, 'Speech to the Electors of Bristol', p. 110.

356 Such is the interpretation presented by, among others, Hanna Pitkin in The Concept of Representation. It is James Conniff, however, who seems to be right; he believes this opinion to be completely mistaken, because in his other speeches to the residents of Bristol Burke explains himself in detail with regard to his specific actions in parliament; cf. James Conniff, 'Burke, Bristol, and the Concept of Representation,' The Western Political Quarterly, Vol. 30, No. 3 (1977), p. 329-341.

357 Cf. Burke, 'Thoughts on the Cause,' p. 170-171.

358 Burke, 'Reflections,' p. 191. Conniff argues that Burke's lack of success in his efforts to call to account those in charge of the East India Company illustrates the theoretical weakness of his concept of representation. Actually, it confirms the validity of Burke's views: those people were not accountable to those they ruled, and thus they did not 
influence that Burke considers indispensable. Thus, representatives are not subject to the control of the represented, but to their assessment, and this is what gives them sufficient freedom in parliament. Burke speaks of expectations on the part of his electorate:

The truth is, I met it on the way, while I was pursuing their interest according to my own ideas. I am happy beyond expression to find that my intentions have so far coincided with theirs, that I have not had cause to be in the least scrupulous to sign their petition, conceiving it to express my own opinions, as nearly as general terms can express the object of particular arrangements $\mathrm{s}^{359}$.

What Burke does not tell his constituents about, or write about, is the party discipline (quite lax at the time, however) that the members of parliament are subject to. According to Heinz Eulau, Burke appreciated the role of parties in politics and did a great deal in order to consolidate the Whig milieu centred around Lord Rockingham. For, notwithstanding all his respect for tradition and the British political institutions, he did understand that in his time politics was pursued in a way different from how it was done when those responsible for the state of the country were accommodated in one chamber: the House of Lords ${ }^{360}$. With undisguised nostalgia Burke concludes:

But the age of chivalry is gone. That of sophisters, economists, and calculators has succeeded; and the glory of Europe is extinguished for ever. Never, never more shall we behold that generous loyalty to rank and sex, that proud submission, that dignified obedience, that subordination of the heart, which kept alive, even in servitude itself, the spirit of an exalted freedom ${ }^{361}$.

Even though he writes those words in his Reflections on the Revolution in France, they apply equally to his own country. Montesquieu might have believed that the monarchy is based on honour, but the one in which Burke lives must

rule in their interest; cf. James Conniff, 'Burke and India. The Failure of the Theory of Trusteeship', Political Research Quarterly, Vol. 46, No. 2 (1993), p. 291-309.

359 Burke, 'Speech on Economical Reform,' p. 131.

360 In a polemic with Hanna Pitkin, Heinz Eulau argues that Burke was actually a man of his party and expounded its interests as general political principles; Burke's trustee is none other than a loyal member of the party organisation; cf. Eulau, 'Changing Views', p. 72-76. Frank O'Gorman, on the other hand, believes this to be a misinterpretation. In his opinion, Burke regarded parties as a transitional phenomenon, indispensable only at times of crisis, which is why he was not interested in internal party politics; cf. Frank O'Gorman, Edmund Burke. His Political Philosophy (Bloomington and London: Indiana University Press, 1973), p. 32-36.

361 Burke, 'Reflections', p. 78. 
resemble a republic more ${ }^{362}$, given that he openly defends party politics, which in Montesquieu's monarchy would be a pathology. There cannot be any other politics when the nation itself is divided ${ }^{363}$. Even so, politics need not and indeed must not mean negotiating group interests in parliament; just like MPs, political parties represent these interests only in the obvious way that they raise them in the parliamentary forum.

What is, therefore, a political party? Burke describes it as a collective body of people united by the same idea and acting together in the national interest. Speculative philosophy sets general goals that the government should pursue, but politicians are 'philosophers in action ${ }^{364}$, and action may only be effective when it focuses the efforts of many individuals with common views, uniting to form parties. For politics is not mere deliberation by representatives, it is also action, and it is parties that are proper political agents. It is parties that draw up agendas and bring together supporters centred around them; they aspire to power in order to implement these agendas. The only groups for which Burke has no sympathy are radical religious parties (the Unitarians), as these all too frequently transfer their religious zest into the political sphere, resembling in this the French revolutionaries, who have gone one step further and substituted abstract ideas for religion ${ }^{365}$.

Ultimately, the picture of deliberation of members of a representative body on the common good from Burke's speech to the voters from Bristol loses much of its clarity. The situation of a politician in parliament is far from comfortable; he needs to reconcile his personal judgement of what is best for the state with his voters' expectations and his loyalty to his party organisation. Actual deliberation occurs in circumstances that do not in the least resemble Habermas' ideal speech situation; Burke was too pragmatic a thinker to consider ideals of that kind at all. Actual deliberation requires not only the knowledge of practical philosophy, but also the virtues of prudence and sagacity, mediatory skills and persuasiveness ${ }^{366}$, i.e. all necessary to make human actions effective when they are interdependent. Burke would not repeat after Aristotle that politics is a domain of freedom.

That is why he resolutely says that the state must be ruled by the best ones: 'The temple of honour ought to be seated on an eminence ${ }^{367}$. The privilege

362 Cf. Burke, 'Reflections,' p. 130.

363 Cf. Burke, 'Thoughts on the Cause,' p. 153.

364 Burke, 'Thoughts on the Cause,' p. 187.

365 Cf. Edmund Burke, 'A Speech on Religious Opinions', in: The Political Philosophy, ed. Hampsher-Monk, p. 262-263, 267.

366 Cf. Burke, 'Reflections,' p. 248.

367 Burke, 'Reflections,' p. 51. 
of representing a community should depend on the representative's personal qualifications. He needs to surpass those whom he represents in wisdom and virtue, which means though Burke does not expressly say so, he cannot be like them. A country should be ruled by a natural aristocracy, one shaped by centuries of history, rather than by an aristocracy of money, as defined by the French electoral law $^{368}$. This group must not be numerous, lest it not feel personally responsible for the affairs of the country that it manages, and this is what may be said of democratic rule, which Burke views as a pathology of the idea of representation.

The share of infamy, that is likely to fall to the lot of each individual in public acts, is small indeed; the operation of opinion being in the inverse ratio to the number of those who abuse power. Their own approbation of their own acts has to them the appearance of a public judgment in their favour ${ }^{369}$.

In a perfect democracy, the most shameless thing in the world, the government is not at all accountable to the people, because the rulers are not personally responsible for the ruled. Thus, the bloodshed in France does not come as a surprise: the government condemns to death people who are anonymous to it. Even though these are to be only sacrifices made on the altar of the new social order, Burke, who does not even notice an outline of that order, rightly predicts that the revolution will grapple with this problem for a long time to come.

For social harmony, he claims, can by no means be created mechanically. The state is a living organism, not a company established to trade in pepper and coffee, calico or tobacco; it is not a carte blanche $^{370}$ on which to test abstract ideas, the way the French are doing now. Guided by population density, they have treated people like 'tokens' and barbarously divided the country into independent administrative units, almost independent republics, whose representatives, like ambassadors, sit on the Assembly, which is National in name only ${ }^{371}$. The state, though diversified, is a historical unity, a community of the past, present and future generations, "linking the lower with the higher natures, connecting the visible and invisible world ${ }^{372}$, with smaller communities organically connected with one another living within its borders. That is why the institution of representation must not divide them - it must bind them; this is the reason why arriving at decisions in politics, with due regard to the diversity of

368 Cf. Burke, 'Reflections,' p. 180-181.

369 Burke, 'Reflections', p. 97.

370 Cf. Burke, 'Reflections,' p. 100-101.

371 Cf. Burke, 'Reflections,' p. 185-189.

372 Burke, 'Reflections,' p. 101. 
conflicting interests, may only be a deliberation on the common good, and not its aggregation from particular goods.

The very inequality of representation, which is so foolishly complained of, is perhaps the very thing which prevents us from thinking or acting as members for districts. Cornwall elects as many members as all Scotland. But is Cornwall better taken care of than Scotland ${ }^{373}$ ?

From the perspective of the state as a whole, it is actually a matter of secondary importance how the representatives of the people are elected, provided that they are capable of thinking in terms of the common interest. However, as such interest objectively does not exist - for the common good cannot be discovered the way the truth is discovered - politics based on the idea of representation consists, broadly speaking, in the rulers working out arrangements that the ruled deem beneficial to the state as a whole. This is what their virtual representation consists in $^{374}$. Burke writes about this most clearly in a letter to Sir Hercules Langrishe:

Virtual representation is that in which there is a communion of interests and a sympathy in feelings and desires between those who act in the name of any description of people and the people in whose name they act, though the trustees are not actually chosen by them... Such a representation I think to be in many cases even better than the actual ${ }^{375}$.

This is, according to Burke, where the difference between aristocracy and democracy lies in. In an aristocracy, the institution of representation selects people who, deliberating on the national interest, create its public order; in a democracy, the same institution is only a source of chaos, as particular interests cannot be simply summed up into the common interest. That is why, Burke quite openly tells his voters that he does not intend to act upon their expectations, but that he will give

373 Burke, 'Reflections', p. 191.

374 Critical interpretations of Burke's writings naturally emphasise the class interest of the nobility underlying his concept; virtual representation is only intended to block a democratisation of the electoral system; cf. Macpherson, Burke, p. 46-49. Gerald W. Chapman has more sympathy for virtual representation: Burke only viewed it as an idea - it was not an accident that he used the word 'virtual', rather than 'actual', even distinguishing between 'virtual people' and 'actual people'; cf. Gerald W. Chapman, Edmund Burke. His Practical Imagination (Cambridge, Mass.: Harvard University Press, 1967), p. 138-142. Heinz Eulau, already quoted above, notes that such an approach locates Burke in opposition both to the concepts of representation of the whole, developed in the Middle Ages, and to the individualistic conceptions arising from Hobbes' philosophy; cf. Eulau, 'Changing Views', p. 68-70.

375 Quoted after O'Gorman, Edmund Burke, p. 55. 
them accounts of his activities. The nation's natural elite cannot be controlled by the people, but must be accountable to it, and an election is the institution that allows the people to exact that accountability.

Thus, to Burke deliberation is not only parliamentary debate, but a complex, several-stage procedure of determining the common good, which has its beginning as early as the candidate's campaign speeches and ends in the passing of laws that will be implemented, under the supervision of the voters, by a government appointed by the king. That procedure, at least in the United Kingdom, is a product of history and tradition of the practical reason of numerous generations, rather than of the doctrinairism of frenzied reformers and revolutionaries. The Glorious Revolution of 1688 did not interrupt the continuity of government, as Burke insists; it was only a transfer of succession to another branch of the same dynasty. The toppling of Stuart rule, Burke admits, was obviously the right thing, but this particular case must not be generalised and each king removed from the throne if his subjects are no longer satisfied with him; privilegium non transit in exemplum, an exception does not become a rule ${ }^{376}$. Thus, it is not an accident that Burke does not even indicate a problem which so obviously presents itself: why should people actually elect as their representatives those politicians who will seek the common good, rather than pursue their particular interests? This question already touches upon the paradox of representation with regard to the common good, which will be fully illustrated by Mill's theory of representative government.

\section{A reformed Polish diet, i.e. an assembly of accountable delegates: Considerations on the Government of Poland by Jean-Jacques Rousseau}

A discussion of Rousseau's views on representation in the Considerations on the Government of Poland must be preceded by a presentation of the criticism of that institution included in The Social Contract, because in its form proposed to the Poles it is meant to prevent the whole evil involved in representative government. To Rousseau, this kind of government is a modern invention, even though the idea itself dates back to feudal government, 'iniquitous and absurd', bringing nothing but dishonour to humanity. Ancient peoples did not know this kind of government, because they enjoyed collective liberty. It was only the modern man, guided by ill-conceived amour propre and juxtaposing his self-interest to

376 Burke, 'Reflections', p. 18. 
the common good, who elevated the private 'ego' above the 'ego' constituting part of the community. Such are, one may say, the mental origins of the modern idea of political representation.

The cooling of the love of fatherland, the activity of private interest, the immensity of States, conquests, the abuse of Government, have led people to imagine the expedient of Deputies or Representatives of the people in the Nation's assemblies. This is what in some countries they dare call the Third Estate. Thus the private interest of two orders is assigned first and second places, the public interest only third place ${ }^{377}$.

Thus Rousseau despises the bourgeois that the citizen has turned himself into, even if he appreciates that the residents of the ancient poleis had much more convenient circumstances for practising virtue than his contemporaries. He admits that the price for the freedom of some was the enslavement of the others; to make it possible for the citizen of the Greek polis to devote all his time to the state, his slaves had to work, for 'perhaps' freedom must be based on slavery. After such a conclusion, his assurances that he does not believe that enslaving people is justified in any way, and that he is only explaining here why the ancients practised slavery, unlike his contemporaries, will not sound convincing to all.

As for you, modern peoples, you have no slaves, but are yourselves slaves; you pay for their freedom with your own. Well may you boast of this preference; I find in it more cowardice than humanity $y^{378}$.

The criticism of representation in The Social Contract is characteristic of Rousseau's maximalist ethics and political philosophy, which are enmeshed in paradoxes of that kind. Aware of the abyss between the old and the new times, Rousseau nevertheless attempts, mutatis mutandis, to find new ways of preventing the alienation of man on the scale of entire states, small groups, individuals and, finally, within one's own soul ${ }^{379}$.

377 Jean-Jacques Rousseu, 'Of the Social Contract,' in: The Social Contract and Other Later Political Writings, Book III, Chapter 15, p. 114. On the possible causes of such a radical view, see Fralin, Rousseau, p. 125-131. Even so, Rousseau considers 'elective aristocracy', a government enforcing laws, elected in the same manner as a parliament is elected in contemporary representative democracy, to be the best form of government; cf. Rousseau, 'Of the Social Contract', Book III, Chapter 5, p. 93.

378 Rousseau, 'Of the Social Contract', Book III, Chapter 15, p. 115.

379 For more on the subject, see Andrzej Waśkiewicz, Strangers by Choice. An Asocial Philosophy of Life, trans. Tulsi Bhambry and Agnieszka Waśkiewicz (Frankfurt am Mein: Peter Lang Edition, 2015), Chapter 5: 'Close to Oneself', p. 215-266. 
However, when he addresses the problem of the common good, then, paradoxically, he is closer to Hobbes' doctrine than to republican tradition. Just like the author of Leviathan, he rejects the substantive idea of the common good, because he is no less a consistent methodological individualist. Unlike the English philosopher, he presupposes the existence of a communal element in each human being, and, preserving the idea of the common good, he changes its meaning so as to reconcile it with that individualism. Consequently, he does not ask what the common good is, but rather how to define it, and replies that it should be defined in terms of the general will expressed by the sovereign.

Only the general will may decide what belongs to the common good, and it may define anything as belonging to the common good. For there is no other authority, whether Divine or human law, before which to challenge the decision of a sovereign people. And because the general will by its very nature cannot stray, it cannot aim at anything but the common good ${ }^{380}$. If, therefore, the legislative makes a decision that later turns out to be detrimental to the people (but who can decide that it was so?), it means that the private interests of the strongest groups and individuals have prevailed within it. Having drawn such distinctions, Rousseau indicates a distinctive feature of the common good, which allows it to be provisionally identified, before the general will pronounces on it: it does not lie in anybody's private interest ${ }^{381}$.

Rousseau's general will is undoubtedly one of the most controversial ideas in the history of political thought - the above opposition does not explain very much here; that is why, any attempt at institutionalising it must be no less controversial. The author of The Social Contract provides only general guidelines on the matter:

If, when an adequately informed people deliberates, the Citizens had no communication among themselves, the general will would always result from the large number of small differences, and the deliberation would always be good. But when factions arise, small associations at the expense of the large association, the will of each one of these associations becomes general in relation to its members and particular in relation to the State ${ }^{382}$.

380 Cf. Rousseau, 'Of the Social Contract', Book II, Chapter 1, p. 57: 'the general will alone can direct the forces of the State according to the end of its institution, which is the common good'; Book II, Chapter 3, p. 59: 'The general will is always upright and always tends to the public utility'.

381 Rousseau, 'Of the Social Contract,' Book II, Chapter 3, p. 60.

382 Rousseau, 'Of the Social Contract,' Book II, Chapter 3, p. 60; Rousseau elaborates on this subject in Discourse on Political Economy. 
And, to leave no doubt, he adds:

It is important, then, that in order to have the general will expressed well, there be no partial society in the State, and every Citizen state only his own opinion ${ }^{383}$.

Thus, in no way can the general will be defined by means of deliberation ${ }^{384}$, as the latter would lead to changing an opinion under the influence of someone else's arguments (this may even be considered the essence of deliberation). Its advocates see the power of reason in this procedure, but all that Rousseau sees behind the alleged reason are social inequalities: a stronger individual ultimately convinces a weaker one. Even though 'empirical' people have more or less sense, they have precisely the same amount of reason as citizens; to say that someone has more reason means to give him, in that respect, power over the others. Thus, the general will may only express itself if it is the collective will of equal people, equal in their freedom, for any inequality is a limitation of freedom.

That is why, government in Rousseau's republic may not represent society with its inequalities; the legislative must be isolated from any influences on its part. The speaker presents the bill drafted by the legislative to the people, and successive speakers offer their comments, but only in the course of debate in a public forum; in fact, they are not allowed to discuss it in any other venue. The assembled citizens consider the speeches exclusively in the silence of their own consciences.

When a law is proposed in the People's assembly, what they are being asked is not exactly whether they approve the proposal or reject it, but whether it does or does not conform to the general will, which is theirs; everyone states his opinion about this by casting his ballot, and the tally of the votes yields the declaration of the general will ${ }^{385}$.

Accordingly, the general will is not so much determined collectively, for this would require deliberation, as guessed within a community, but each of those gathered does that separately ${ }^{386}$. The object of choice, observes Daniel Cullen, must exist independently of the choice itself, however, meaning that it is not

383 Rousseau, 'Of the Social Contract', Book II, Chapter 3, p. 60.

384 In Discourse on Political Economy Rousseau writes that Athens was in fact not a democracy, but 'a most tyrannical aristocracy governed by learned men and orators'; cf. Jean-Jacques Rousseau, 'Discourse on Political Economy', in: The Social Contract and Other Later Political Writings, p. 8.

385 Rousseau, 'Of the Social Contract', Book IV, Chapter 2, p. 124.

386 On how the Jacobins first tried to institutionalise the general will, see François Furet, Interpreting the French Revolution, trans. Elborg Forster (Cambridge: Cambridge University Press, 1997), Part One: The French Revolution is Over. 
the will of those assembled that constitutes it, but rather the solidarity of the community members underlying that community ${ }^{387}$. As a result of the vote, in which the opinion of a majority usually decides, the sovereign recognises that it is the general will that makes proposed legislation a law, because it will be conducive to the common good of the Republic: the vote bears evidence of the fact that Rousseau puts the will of equal individuals above deliberative reason ${ }^{388}$. Actually, his metaphors suggest that the sovereign pronounces on the general will in the same way as the Church announces God's will, which is nowhere clearly expounded either.

Can this kind of procedure for determining the general will be successfully applied in a large state, as large as 18th-century Poland, in which the people, even if this is limited to one order - the gentry - cannot assemble regularly? Rousseau indeed considers the size of the Polish state to be the biggest problem for this form of government and the cause of many misfortunes. It is a problem not only for Poland, incidentally, which shares this affliction with all civilised nations, no matter what their form of government. An excessive expansion of the state is 'the first and principal source of the miseries of humankind'. That is why, probably to the readers' surprise, Rousseau speaks with some approval of 'a reform in the size' of the country, or of 'contracting' its 'boundaries' ${ }^{389}$. The partitioning powers unintentionally rendered Poland an important service by taking away part of its territory.

This view is by no means astounding, considering Rousseau's entire political philosophy, but odd in this treatise in so far as it is not justified in any other way. For Rousseau does not claim that the lands taken away had been contentious, such that after their loss the subject of a neighbourly dispute has disappeared and the Polish state will be able to focus on internal reform; nor does he claim that they were not ethnically Polish, such that relations between the ethnic groups inhabiting them had caused internal friction. The optimum size of the state follows exclusively from the system of government, no matter who resides within its borders and how big the population is: Rousseau fully applies this principle to the Poland of that era. Aware of the controversial character of the 'solace' offered, he only admits that any further cutting down of the territory

387 Cf. Daniel E. Cullen, Freedom in Rousseau's Political Philosophy (DeKalb: Northern Illinois University Press, 1993), p. 118.

388 Cf. Cullen, Freedom in Rousseau's, p. 149.

389 Cf. Rousseau, 'Considerations,' Chapter V, p. 193-194. 
would certainly be disadvantageous to the lost parts, even though very good for the remaining whole.

If, however, the Poles decide that they should unconditionally defend the integrity of their state, the only thing for them to do is to introduce a federal system, the only system to combine the advantages of small and large states (of which Rousseau does not write). And again this is not because Poland is naturally diversified and its parts should be granted autonomy for that reason; actually, that is not the case, but even so it should be divided into smaller political units:

Let the separation between the two Polands [i.e. the two regions known as Greater Poland and Lesser Poland (Wielkopolska and Małopolska) - A.W.] be as pronounced as that between them and Lithuania: have three States united into one. If possible, I would wish you to have as many as you now have Palatinates; form within each one of them an equal number of individual administrations. Perfect the form of the Dietines, extend their authority within their respective Palatinates; but carefully fix their limits, and make sure that nothing can break the bond of common legislation between them or break the bond of subordination between them and the body of the Republic ${ }^{390}$.

In a sense, Rousseau therefore recommends something against which Burke so resolutely warns: the national parliament is to become a representative body of ambassadors of separate states. What is, therefore, their federation? How can it remain a unity? It is not an accident that Rousseau precedes his recommendations concerning the administrative division with a lecture on patriotic education. Whether a small republic of one people or a large federal republic, the state must develop a civic culture common to all, must bond to itself all the people living within its boundaries ${ }^{391}$ and ensure their loyalty. Characteristically, the author of the Considerations does not say a single word about civic religion in his recommendations ${ }^{392}$.

What can integrate people as citizens when the institutions of the political system consistently divide them? It is here that Rousseau initially seems to make

390 Rousseau, 'Considerations', Chapter V, p. 194.

391 A characteristic description of such holidays designed to integrate the civic community is included in Rousseau's 'Letter to M. d'Alamert on the Theatre', in: Politics and the Arts, trans. Allan Bloom (Ithaca, New York: Cornell University Press, 1968), p. 123-137.

392 Perhaps, as Fralin supposes, this was because in view of the dominance of the Catholic Church he considered this solution unrealistic and had to accept Catholicism as a temporary equivalent of civil religion (cf. Fralin, Rousseau, p. 180). Or perhaps it was only out of fear for his own safety. The Social Contract was burnt in Geneva and Paris precisely because of the chapter on civil religion. 
a transition from classical republicanism to political Romanticism, combining the idea of liberty with the idea of the nation, as well as combining the ideas of two nations: a political body, constituted by a social contract, and a natural organism, shaped in the course of history. Here is the philosopher's advice to the Poles:

Upon opening its eyes, a child should see the fatherland, and see only it until his dying day. Every true republican drank love of fatherland, that is to say love of the laws and of freedom, with his mother's milk. This love makes up his whole existence; he sees only his fatherland, he lives only for it; when he is alone, he is nothing: when he no longer has a fatherland, he no longer is, and if he is not dead, he is worse than dead.. At twenty a Pole should not be just another man; he should be a Pole ${ }^{393}$.

But what does it mean to be a Pole? Does Rousseau indeed speak here of a nation in the ethnic sense? Not at all - he never defines Polishness in terms of shared origins and destiny ${ }^{394}$. As evidenced by their resistance to Russian imperialism, the Poles owe their identity to their love of freedom - though not individual, but collective freedom. That sentiment had not even been destroyed by Poland's territorial expansion, which Rousseau considers simply phenomenal. However, history has also brought about something disagreeable: the Poles have been unable to make good use of their freedom; they have been unable to protect it as citizens. If they now follow the philosopher's advice, they will create a free state, even if not one, he admits, to command admiration in Europe, for the latter does not appreciate freedom any more. Even if it is too late to defend the state against the aggressive neighbour to the East, the reforms undertaken will allow the spirit of freedom to be preserved in bondage ${ }^{395}$.

The system of political institutions designed by Rousseau, or rather an extensive reform of the existing institutions, is intended to uphold the republican spirit among the citizens, even though they will not occupy themselves what they

393 Rousseau, 'Considerations,' Chapter IV, p. 189.

394 Jeffrey A. Smith argues that Rousseau actually subordinates the nation to the republic, considering it important in so far as it promotes civil virtue; cf. Jeffrey A. Smith, 'Nationalism, Virtue, and the Spirit of Liberty in Rousseau's Government of Poland, The Review of Politics, Vol. 65, No. 3 (2003), p. 411-412.

395 Cf. Rousseau, 'Considerations,' Chapter 3, p. 183. That is why Smith claims that the freedom which Rousseau attributes to the Poles is 'intentional' - being free 'in their hearts', they will not lose their freedom even under absolutist rule - and notes a characteristic paradox: according to Rousseau, the Poles seem to maintain that freedom precisely because it is threatened; what if it were not? Cf. Smith, 'Nationalism, p. 413-414, 417. 
should occupy themselves with in a republic, i.e. lawmaking. In view of the size of the state, it is impossible; Rousseau's solution is only designed to ensure that they will not be subject to a law to which they have not given their consent. Thus, they will collectively preserve an attribute of sovereignty, unless they hand it over to their representatives. For a sovereign may delegate the exercise of power to others, but he may not hand over the power itself to them.

This is the difference between delegation and representation. A delegate does not act on someone's behalf, but only in his place; he only does that which is allowed to him as per a mandate by which he is bound. Consequently, he is not a trustee of the represented in the sense that was given to that term by Locke and Burke; he does not act in the best interest of the citizens as he himself understands it, but as they understand it themselves. All he does is transfer their will to the lawmaking forum.

Rousseau firmly recommends that that principle be preserved, considering it to be 'the true Palladium of freedom'; the principle had been known in the Polish Commonwealth for centuries, but had always been, at the same time, the target of criticism of government reformers. The dietines, or provincial diets, do indeed need to be reformed to make their work more orderly, but it is they, like no other institution, that can prevent 'this terrible evil of corruption ${ }^{396}$. Bound by their mandate, delegates to the general diet do not deprive the whole nation of the gentry of its sovereignty: in a federal state, provincial diets will actually be the sovereign's assemblies. Characteristically, Rousseau leaves some things unsaid; he does not claim that the dietines perform the function of the sovereign across the state, but only that to the divided nation of the gentry - they are the institutions in which the general will takes shape, though in each one separately. However, how does the general will shaped within them relate to the laws made by the general diet?

Delegates of the provincial dietines, bound by their instructions, make up the national legislative assembly. Rousseau emphasises that the entire gentry of a given province must give its instructions, which is understandable in so far as this act is now an equivalent of determining the general will by a civic assembly. In the general diet, decisions are made by a majority, as they are in communes (cities) with direct popular rule. Not without hesitation, Rousseau maintains the liberum veto, but recommends resorting to it exclusively in matters of fundamental importance to the system of government ${ }^{397}$; on other important matters,

396 Cf. Rousseau, 'Considerations,' p. 201.

397 Rousseau, however, has an ambiguous attitude towards it: 'The liberum veto is not in itself a vicious right, but as soon as it exceeds its bounds it becomes the most dangerous 
a qualified majority should be sufficient ${ }^{398}$. In an institutional order of this kind, the common good would be nothing but an aggregate of fragmentary goods, i.e. the goods of individual provinces; the veto right and the qualified majority would protect minorities, preventing a violation of their fundamental rights. Thus, the legislative body would resemble not so much a present-day parliament as a general assembly of a major enterprise, peculiar only in so far as each shareholder holds an equal share in it.

Rousseau's own corrections ruin the very foundations of this procedure, however, as the philosopher precludes voting by provinces; even though this kind of vote is conducive to the stability of federal arrangements, it represents, in itself, a greater threat to citizens' freedom:

Aggregated and collective votes [i.e. cast jointly as a single vote of the whole province A.W.] always point less directly to the common interest than do separate votes, individual by individual. Very often among the Deputies of a Palatinate there is one who, in their private deliberations, will assume ascendancy over the others, and sway to his opinion a majority which would not have sided with him if each vote had remained independent. Corruptors will thus have less to do and know better whom to approach; moreover, it is preferable to have each Deputy answerable for himself alone in his Dietine, so that no one can invoke the others as an excuse, the innocent and the guilty not be confused, and distributive justice be better observed ${ }^{399}$.

Even though Rousseau leaves a number of detailed matters, even crucial ones such as a division of competences between the diet and dietines ${ }^{400}$, for the Poles to decide, he discusses the matter of the mandate and instructions punctiliously ${ }^{401}$. He himself decides who should be on the commission drawing up the instructions, how to elect its members, who should preside over it, etc. $\mathrm{He}$

of abuses: it used to be the guarantor of public freedom; now it is nothing but the instrument of oppression' (Rousseau, 'Considerations', Chapter 9, p. 216). Elsewhere he writes explicitly: 'For, I dare say, it is outrageous that anyone who thus breaks up the operation of the Diet and leaves the State without recourse should go home to enjoy tranquilly and with impunity the public havoc he has wrought' (Chapter 9, p. 218-219).

398 Cf. Rousseau, 'Considerations,' Chapter 9, p. 218.

399 Rousseau, 'Considerations', Chapter 7, p. 209-210. That is why, Rousseau does not address the question of whether according to the federal principle one province should have one vote or rather a number of votes proportionate to the size of its population.

400 Fralin rightly observes that that system of government resembles a federation rather than a confederation, just like Rousseau's outline of a form of government for Corsica; cf. Fralin, Rousseau, p. 124, 174.

401 Cf. Rousseau, 'Considerations,' Chapter 7, p. 201-202. 
strongly emphasises the control exercised by the dietine over its delegates. A kind of formal representation agreement will be contracted with each one of them (the delegates sign a copy of the instructions deposited in the dietine's records). The delegate will be held accountable for complying with this agreement, point for point, and will have to prove before the dietine that he followed the instructions at the general diet (where votes are cast not by ballot but by voice ${ }^{402}$ ), or at the very least did nothing against the express will of his diet. Unless duly authorised by his dietine, he may not even speak on matters that have appeared unexpectedly on the agenda. He may express his own opinion - Rousseau allows an exception to the rule here - only provided that he has the consent of his constituents, and what he says is not contrary to the instructions.

The Deputy must, with every word he speaks in the Diet, with every action he takes, anticipate himself under the scrutiny of his constituents, and sense the influence their judgment will have on his projects for advancement as well as on the esteem of his fellow citizens, which is indispensable for the realization of these projects of his: for after all the Nation sends Deputies to the Diet not in order to have them state their private sentiment but to declare the wills of the Nation. This restraint is absolutely necessary to hold them to their duty and to prevent all corruption, from whatever quarter it might come $e^{403}$.

Thus, an obligatory mandate ultimately turns out to serve not so much to transfer the wills of the diets to the general diet forum as to bind delegates themselves to their dietines.

One must, however, not allow oneself to be seduced by Rousseau's rhetoric. The delegates' accountability is nothing but political. For what will befall those who have not followed their instructions? In the worst case, they will not be delegated to the next diet, which does not seem to be an overly strict punishment. And even if they acted against the dietine's will, they may still be able to persuade it afterwards that they were not acting in their own interest, but for the common good. Actually, Rousseau seems to have anticipated that margin of freedom; the instructions themselves could be so self-contradictory that it would be impossible to make any kind of decision, and if this were in fact the case, the delegates' explanations should be accepted.

Perhaps he even, without explicitly saying so, expects the delegates to vote against the instructions in the name of the common good of the state as a whole in obvious cases, and the dietine, animated with a patriotic spirit, to consider their conduct to be justified or even commendable. For civic education, to which

402 Rousseau, 'Considerations,' Chapter 7, p. 210.

403 Rousseau, 'Considerations,' Chapter 7, p. 202. 
all the citizens are subject, is designed to teach them to think in terms of the common good, and to the Pole the common good is not the good of his province but of the country as a whole. Even so, the members of the legislative are in a paradoxical situation: they are supposed to act for the common interest of the state as a whole and at the same time they must not act against the interests of their provinces, while these interests must regularly clash. Are therefore the interests of the provinces, expressed at the general diet, nothing but particular interests, and the general will of each dietine a particular will? If so, it becomes all the more clear why the delegates are not allowed to vote by whole provinces at the general diet: in no case can the general will be derived from particular wills. The delegates are bound by the same principle that Rousseau formulated in The Social Contract, that is: 'Each individual should have his vote, no [corporate] body whatsoever should have one ${ }^{304}$.

Any possibility of aggregation of the common good from particular goods is precluded here, as the very existence of a particular will in the national legislative assembly is excluded. A procedure of that kind would be contrary to Rousseau's fundamental political idea, i.e. equality, for precisely the same reasons as deliberation. Thus, the delegates of the dietines to the general diet do not define the general will in place of those who have delegated them, i.e. the nominal sovereign ${ }^{405}$. Nor do they define it as a separate body; this is not possible, as the general will is defined by the body of citizens as a whole. Indeed, Rousseau avoids this term in the Considerations; Kendall rightly notes that it is replaced in the treatise by the ancient virtue of the citizens ${ }^{406}$.

What purpose, therefore, is to be served by the federal division of the country into administrative units, if their general wills cannot be aggregated in the

404 Rousseau, 'Considerations,' Chapter 7, p. 206. Rousseau expresses this idea in a more 'sociological' way: 'Now the law, which is but the expression of the general will', he writes, considering the status of the senate, 'is indeed the resultant of all the particular interests combined and in balance by virtue of their large number. But corporate interests, because of their excessive weight, would upset the balance, and should not be included in it collectively'.

405 In Discourse on Political Economy, written before The Social Contract, Rousseau even gives the reasons why the presence of the whole nation is not necessary in determining the general will: there is no certainty that the nation will recognise it correctly; additionally, in large states it would be difficult to gather it together; thus, decisions may be made by rulers, provided that they are guided by goodwill: 'one need only be just in order to be sure of following the general will'; cf. Rousseau, Discourse, p. 12.

406 Kendall, How to Read, p. XIX. 
legislative body to define the general will of the nation as a whole? Ultimately, its only purpose is to exact the government's accountability to the ruled; Rousseau regards the lack of such accountability as the greatest weakness of representative government. What this means, however, is that in the case of indirect exercise of power, i.e. its exercise by delegates, the sovereignty of the people may not consist in anything but in controlling their delegates. Instructions are to formalise this accountability; the fact that the delegate is bound by them should give the citizens at least a sense that their voice cannot be ignored in the legislative body even if they cannot make laws themselves. The decisions made by the house of delegates will sometimes be contrary to their own wills and individual interests, but such a situation also occurs in a republic, where law is made by a general assembly of citizens. Speaking in terms of the common good, even though the people of the federal republic cannot define it themselves, they will be on their guard to ensure that the assembly delegated by the civic community is not guided by its own interest.

\section{The rule of an intellectual elite in the representative body: Considerations on Representative Government by John Stuart Mill}

Addressing his design of representative government to mature societies, Mill, a liberal and eulogist of individualism, seems to follow the Aristotle of the Nicomachean Ethics, extending his concept of human maturity to entire human communities. Like mature people seeking happiness, societies ripe for that type of government are guided by their own interest, but a well-defined one. Because Mill is a sociological nominalist, he believes that most members of those societies understand that in addition to their purely individual interests, they also share some interests with others: in that sense, these interests are general. The philosopher's considerations on the limits of interference in the sphere of personal freedom, included in his trademark essay On Liberty, also allow this matter to be interpreted from a different angle: in a mature society, people are able to determine the limits of their individual freedom, while in other societies this has to be done arbitrarily by the government, with a view to ensuring their survival.

Representative government is as much an achievement of humanity in the course of its historical evolution as an expression of the weakness of human nature: even if entire societies are ready for it, their individual members are ready to varying degrees. For Mill, a utilitarian, assumes that even in enlightened societies, most people are guided by wrongly (i.e. too narrowly) defined selfinterests. Thus, representation in the first place serves the purpose of selecting 
those who better understand common interests and thus take them into consideration in their calculations.

It is only a disinterested regard for others, and especially for what comes after them, for the idea of posterity, of their country, or of mankind, whether grounded on sympathy or on a conscientious feeling, which ever directs the minds and purposes of classes or bodies of men towards distant or unobvious interests. And it cannot be maintained that any form of government would be rational, which required as a condition that these exalted principles of action should be the guiding and master motives in the conduct of average human beings. A certain amount of conscience, and of disinterested public spirit, may fairly be calculated on in the citizens of any community ripe for representative government. But it would be ridiculous to expect such a degree of it, combined with such intellectual discernment, as would be proof against any plausible fallacy tending to make that which was for their class interest appear the dictate of justice and of the general $\operatorname{good}^{407}$.

Without invoking Plato, Mill actually repeats after him, though in a more reticent manner, one of the oldest topoi of the criticism of democracy ${ }^{408}$. Representative democracy is to prevent the weaknesses of direct democracy, or pure democracy, as it was called at that time. Thus, it is located in double opposition: against both absolutist and hyper-democratic government, the rule of 'one' and of 'all', to use Aristotle's language. Is that why this form of government is nothing but an 'elective aristocracy', to use Rousseau's term? Mill's argument, which will be discussed below, is designed to convince the reader that this is not the case; the

407 Mill, Considerations, p. 126. Mill, Duncan points out, interpreted the term 'class' very broadly: it was used to describe great landowners, manufacturers, skilled and unskilled labourers, but also Spartans and helots, planters and slaves, princes and subjects, the gentry, men and women; cf. Duncan, Marx and Mill, p. 219.

408 While discussing Mill's writings from before the publication of the treatise under discussion, Richard W. Krouse, following Duncan's work mentioned above, even writes about his 'democratic Platonism'. Before Mill changed his mind and began to appreciate the value of democracy in civic education, like de Tocqueville, he compared the relationship between the representative body and its electors to the relationship between a doctor and his patient; cf. Richard W. Krouse, 'Two Concepts of Democratic Representation: James and John Stuart Mill,' The Journal of Politics, Vol. 44, No. 2 (1982), p. 524-525. Attributing an aristocratic character to Mill's liberalism, Alan S. Kahan notes with a degree of amazement that Mill, like de Tocqueville, had the highest regard for the system of government of contemporary Prussia, in which the extent of political rights depended on the amount of tax paid, preferring it to the British Reform Act of 1832; cf. Alan S. Kahan, Aristocratic Liberalism. The Social and Political Thought of Jacob Burckhart, John Stuart Mill, and Alexis de Tocqueville (New York - Oxford: Oxford University Press, 1992), p. 72-73. 
author of the treatise expects much more from the people than a mere election of representatives.

As evident from the above quotation, he leaves no doubt that representation is more than a mere technical necessity in a state too big to cope without it. The philosopher predicts a representative body even at the local level, where numerous matters could be decided by the citizens directly at communal and municipal assemblies; without explaining his aversion towards that institution, he contents himself with stating that it is 'a relic of barbarism', inconsistent with the new times ${ }^{409}$. He regards local parliaments as a permanent element of each representative system ${ }^{410}$. (Their competence should cover everything that pertains to local affairs, and does not pertain to national affairs, even though the border between the two must of course be in a sense conventional.) Accordingly, all government bodies are to be representative bodies.

Mill explains his aversion towards communal and municipal assemblies in his Autobiography ${ }^{411}$. It was de Tocqueville's On Democracy in America, he admits, that alerted him to the danger of a tyranny of a majority (which he expressed most emphatically in his essay On Liberty) and made him realise that it was necessary to limit all forms of the people's direct political activity. Unlike de Tocqueville (to be discussed in the following chapter), Mill believes that all threats to individual liberties which have their source in collective emotions can be prevented institutionally. If these liberties were threatened also by representative government, Mill would not hesitate to replace it with a form of enlightened absolutism that would protect them. Thus, Mill's representative government, as seen in opposition to an autocracy, is a government of an enlightened people, but, contrary to direct democracy, it remains a rule over the people, and this is where its fundamental antinomy lies.

However, as a belief in continuing social progress is quite an important tenet in Mill's doctrine, one may ask once again about the character of that government. Given that it promotes social progress more than any other form of government - which, among other things, makes it superior - is it not transitional

409 Nadia Urbinati develops an argument that might be attributed to Mill: representation protects citizens against orators and their 'direct speech', offering them distance and time for reflection and for considering the arguments, something that direct democracy institutions fail to provide; cf. Nadia Urbinati, 'Representation as Advocacy: A Study of Democratic Deliberation,' Political Theory, No. 28 (2000), p. 762-768.

410 Cf. Mill, Considerations, p. 273-274.

411 Cf. John Stuart Mill, Autobiography (Oxford: Oxford University Press, 2018), p. 108-110. 
precisely for that reason? Will public enlightenment not progress so far at some point as to render a vast majority of citizens capable of making decisions in the interest of all? In that case, representation would merely be a technical necessity, which might be replaced, e.g., by a more egalitarian institution of drawing lots to determine the composition of government bodies. This question is all the more valid because Mill, like Burke and Rousseau, though for very different reasons, does not in any way invoke representation as the idea and institution legitimising the government; to him, it only serves the purpose of appointing government bodies.

Even if this were indeed the case, in every society there will be people capable and more capable of exercising power; the institution of representation is designed not only to remove from power people completely incapable of exercising it, but also to select the most gifted ones. They do not make up a closed, aristocratic group. The expertise that gives one an informal title to power is available to everyone; by no means is it the kind of special knowledge that only Plato's philosopher king may have. However, only those who take an interest in public life make practical use of it, as only they are able to elect the most virtuous and wisest individuals from among themselves, no matter which social strata they come from ${ }^{412}$. A society ripe for representative government must therefore be egalitarian enough to entrust power over itself to a natural elite of character and intellect, rather than to the richest or those with a glorious service record on the battlefield.

A representative constitution is a means of bringing the general standard of intelligence and honesty existing in the community, and the individual intellect and virtue of its wisest members, more directly to bear upon the government, and investing them with greater influence in it, than they would in general have under any other mode of organization $^{413}$.

It is in this context that one should view the necessary exclusions from the procedure. For people without the basic reading, writing and arithmetic skills, as well as those who do not pay taxes, are permanently in debt or live at the expense of

412 It follows that Mill's entire argument is based on one premise that is by no means obvious or is outright false. For he assumes that primitive peoples are guided by narrowly defined self-interest, meaning that Mill implicitly attributes to human nature the individualism of Western civilisation, which becomes pro-social only with advances of public enlightenment. Naturally, that kind of individualism is alien to a vast majority of primitive peoples; moreover, it seems that it is the collectivism of such peoples that will be more conducive to thinking of government in terms of general interest.

413 Mill, Considerations, p. 32-33. 
the parish (drawing benefits), are unable to elect responsibly; their own situation in life bears witness to their irresponsibility. On the other hand, Mill does not see any justification for the widespread belief attributing such irresponsibility to women because of their sex and the character of their everyday occupations (which is the subject of a separate treatise On the Subjection of Women). All who are 'in the normal condition of a human being' should have the right to vote; it must not be denied to entire social categories, only to individuals who do not meet particular conditions, and only as long as they fail to meet them.

And if any one has to forego it, he either does not care sufficiently for it, to do for its sake what he is already bound to do, or he is in a general condition of depression and degradation ${ }^{414}$.

An individual in that condition, Mill argues, does not appreciate political rights anyway.

The philosopher is so eager to ensure that people surpassing others in virtue and intellect make up a representative body that he openly designs institutions of representation in such a manner as to promote their election. In doing so, he even sacrifices the fundamental principle of democratic equality (one individual, one vote), instead granting an extra vote to educated individuals. For the weight of the vote should be differentiated in view of the result it may bring. Wiser individuals make wiser choices; Mill believes that his rule will also be understandable to those he leaves with a single vote. Practical difficulties prevent holding a universal (general knowledge) exam as the basis for granting this right; let us therefore give this opportunity to those who demand it; meanwhile, it will be granted to university graduate ${ }^{415}$. Naturally, no contemporary political scientist would have any problems with indicating the political party privileged

414 Mill, Considerations, p. 171.

415 Cf. Mill, Considerations, p. 176-178. One of the important disputes concerning Mill's political views is whether behind the education he so strongly emphasised, there hides perhaps a class element. Defending Mill's egalitarianism, Maria H. Morales argues that Mill himself never associated education with class, and that he considered the above solution temporary, to remain in force only until the voters' levels of knowledge rose; cf. Maria H. Morales, Perfect Equality. John Stuart Mill on WellConstituted Communities (Lanham - Boulder - New York - London: Rowman \& Littlefield Publishers, 1996), p. 85-86. Duncan points out that Mill had doubts as to whether any class might rule in the general interest, but ultimately he optimistically believed that this was what the growth of knowledge led to; cf. Duncan, Marx and Mill, p. 281-282. 
by such an electoral law in his own country, but Mill 'ingeniously' assumes that it only serves the election of the best from among the best ${ }^{416}$.

Other measures designed to facilitate the incorporation of an intellectual elite into a representative body include a possibility of running for Parliament outside party lists (because political parties place their loyal members, rather than those thinking independently, at the top of their lists) and of electing representatives from outside the voter's own constituency (a measure that will benefit independent candidates the most). Thus, candidates who enjoy well-deserved respect among the general public but are unable to win a majority in their own constituency might win a seat by the votes of an educated minority dispersed all over the country ${ }^{417}$.

Finally, having considered the advantages and disadvantages of a bicameral parliament in his country, Mill, after some hesitation, provides for a second house to replace the House of Lords, which, in the shape it was in in the philosopher's day, exclusively represented the wealthy. The second house should not, however, be a representative body, but a council of statesmen, former high officials, proven in public service and endowed with public authority, to whom Mill adds a few scholars and university professors, and even writers (with the exception of political commentators). Consequently, it is to be a group of wise people, but by no means experts; there is no place in that body for any economist or lawyer by virtue of his profession alone. The freer this house is from 'the class interests' on the one hand, and from 'prejudices of the majority' on the other, the better it will play its role. One may say that what the members of the house share is the fact that they would probably not have been elected in a democratic election ${ }^{418}$.

Analogies with Plato's Republic that suggest themselves here are not pertinent. What Mill wants is not only for wise individuals to rule the state; it is equally important to him that they are elected by the others. Enlightened peoples are the masters of their own destiny precisely because they may choose wise rulers for themselves, unlike unenlightened peoples which only may, by a twist of fate, happen to have an enlightened despot as a ruler. However, even

416 This optimism is also surprising because, according to Maria H. Morales, Mill did not share Bentham's faith in institutional reform and considered broadly defined education more important; cf. Morales, Perfect Equality, p. 50-51. On the other hand, Alan S. Kahan argues that Mill's attitude towards formal education was simply ambivalent; he did not believe that it inspired the love of freedom; cf. Kahan, Aristocratic Liberalism, p. 103.

417 Cf. Mill, Considerations, p. 139-143.

418 Cf. Mill, Considerations, p. 238-240. 
an enlightened despot cannot do anything more for his people than maintain a political order and create conditions conducive to them expanding their general knowledge. Greater knowledge leads to involvement in communal affairs, but no more than public debate itself; that is why an enlightened society is a debating society. Opinions clash within it, and none of them should be considered sacred and indisputable. To representative government, a thing no less important than knowledge itself is the method of acquiring it. In his essay On Liberty Mill writes:

There is the greatest difference between presuming an opinion to be true, because, with every opportunity for contesting it, it has not been refuted, and assuming its truth for the purpose of not permitting its refutation. Complete liberty of contradicting and disproving our opinion, is the very condition which justifies us in assuming its truth for purposes of action; and on no other terms can a being with human faculties have any rational assurance of being right ${ }^{419}$.

The debate under discussion is to be conducted not only in the parliament buildings, but in the entire public sphere, and it should continue without interruptions. Unless it is the citizens who define goals for the government, both the long-term and the short-term ones, the government will set them itself, so it will no longer be representative. Mill might even perhaps agree with Rousseau's sarcastic remark that Englishmen are free only once in a few years, when they cast their votes in a parliamentary election, if they are later unable to influence the rulers in any way. Unlike contemporary critics of representative democracy, Mill assumes therefore that political life in this form of government may be as intense as in direct democracy and may thus avoid that characteristic cyclical pattern. Unlike Rousseau, he would be ready to argue that the division into the rulers and the ruled need not be a rigid one. Three-year parliamentary terms should keep up the state of public animation characterising the election time, while at the same time allowing the representatives enough time for them to prove their qualifications to the citizens; however, their qualifications, too, should be judged in terms of the common good rather than individual interests ${ }^{420}$.

For in the long term, counted in decades, not terms, the government's indisputable goal is public service, which consists in the government promoting social progress. Even though the government of a mature society leaves their private

419 John Stuart Mill, 'On Liberty', in: On Liberty and Other Writings (Cambridge: Cambridge University Press, 1989), p. 22. Mill is a pluralist, but not a relativist; he does not question the very idea of truth. Without it, the whole debate discussed below would be beside the point.

420 Cf. Mill, Considerations, p. 220. 
affairs for the citizens to decide, it is by no means unimportant to it what kind of use they make of their freedom. It is on this matter that Mill turns out to be, paradoxically, more of an Aristotelian than a liberal. The government must of course ensure the people's security and provide conditions for material growth; even so, what determines the actual value of a government is ultimately the degree to which it tends to 'increase the sum of good qualities in the governed, collectively and individually ${ }^{321}$, meaning that it should also create conditions for personal development for the citizens, or, in Aristotle's idiom, make it possible for them to perfect themselves in the art of living.

Mill expresses this paideia in a modern way, however. To him, a mature man is an individualist. For to him individualism is not, unlike in de Tocqueville's definition of it, the attitude of isolation in an egalitarian society. Quite the contrary, it means taking responsibility for one's community with a sense of one's own strength and the validity of one's arguments; it is an individualism within, not outside the community. Mill's individualists are in fact individualities, distinguishing themselves among the individuals populating an egalitarian society. They owe the strength of their character neither to religious faith nor to tradition, but to debate itself; like the hypothesis in an ideal scientific procedure, their opinions pass through the test of criticisms irrespective of the status of the individual who voices them. A strong personality is forged in confrontation with others.

That is why Mill, while appreciating the arguments against it, defends the principle of an open ballot. In a society ripe for representative government, the pressure of the economically dominating classes is no longer strong enough for hired labourers to fear repression on the part of their employers ${ }^{422}$. Actually, a government elected under pressure does not subsequently feel the pressure of the voters, but according to Mill an open ballot should promote a sense of responsibility among the voters themselves even more than it serves to control the

421 Mill, Considerations, p. 30.

422 Contrary to the prevailing interpretation of Mill's philosophy, John Edward Broadbent argues that he attached major importance to class (economic) divisions in society; one of the aims of representative government was precisely to prevent the representative body from assuming a class character and making laws serving the interests of one class only. Moreover, Mill had no doubt that ideas evoke a response among the public only if they win the support of entire classes; cf. John Edward Broadbent, 'The Importance of Class in the Political Theory of John Stuart Mill,' Canadian Journal of Political Science, Vol. 1, No. 3 (1968), p. 276-278. 
government. The critics of that principle emphasise the pressure that the voter is subject to during a vote by open ballot, and Mill admits that they are right:

To be under the eyes of others - to have to defend oneself to others - is never more important than to those who act in opposition to the opinion of others, for it obliges them to have sure ground of their own. Nothing has so steadying an influence as working against pressure ${ }^{423}$.

Open ballot is therefore the procedure in which the goals of representative government may be seen most clearly. It is meant to teach citizens to make responsible choices, because their consequences influence not only the voters themselves but society as a whole; it also serves to sustain an active political life, given that one might have to explain oneself later to one's fellow citizens for voting in a particular way. For these reasons, political activity should shape strong personalities. In associating the character of a man with the form of government, Mill therefore addresses one more characteristic theme in Aristotle's philosophy: the relationship between a good person and a good citizen.

On this issue, Mill's view is contained in his idea of individualism. A good man cannot be a bad citizen, for as a member of a certain community he is, within his ability, responsible for it. But to be a good citizen is not the same as to be an obedient citizen. Quite the contrary - and Mill says this as a liberal - it means to maintain a critical distance from any government, in particular when it enjoys the support of most of the people. For the state is best served by critical individuals who do not allow it to sink into routine, by citizens who will not think collectively but independently. Thus, what it takes to achieve the common good is an individual contribution from each citizen; en masse, they only express widely shared prejudices.

Thus Mill, like Rousseau, imparts a clearly subjective dimension to the problem of the common good, though he does so less dramatically. However, Mill's man-citizen is not rent between 'amour propre' and 'amour de soi'. His only problem is the rationality of his choices, but there is one intellect, not split, and subject to improvement; an enlightened intellect reconciles individual interests with the general interest. It is in the general interest for the citizens to be not only loyal towards their state, but also critical of it, even if their individual interest often makes them adopt an attitude of conformism vis-à-vis the government. Paradoxically, the government, which is expected to promote the common good, should, in the name of that same common good, almost encourage the ruled to criticise it with civic spirit, because criticising the government is an inalienable

423 Mill, Considerations, p. 207. 
part of the political life of a mature society, rather than an introduction to revolt ${ }^{424}$. A revolt may occur only when the rulers respond to criticism with oppression, thus bearing testimony to their alienation. For the ultimate power over society rests with public opinion, and it is the public that institutions of political power are to serve.

Mill's attitude towards this obvious fact is characteristically ambivalent, however. For he distinguishes, as he puts it in the title of, between 'true' and 'false' democracy: representation of all and representation of the majority only. In a true democracy, each party is represented proportionately to its influence in society; in a false democracy, the majority has power.

A majority of the electors would always have a majority of the representatives; but a minority of the electors would always have a minority of the representatives. Man for man, they would be as fully represented as the majority. Unless they are, there is not equal government, but a government of inequality and privilege: one part of the people rule over the rest: there is a part whose fair and equal share of influence in the representation is withheld from them; contrary to all just government, but above all, contrary to the principle of democracy, which professes equality as its very root and foundation ${ }^{425}$.

The basic problem lies in the fact that minority opinions are frequently dispersed; even if they are visible on the national scale, they do not make up a local majority in any constituency. Because of a majority electoral law, minority voters have no representation in parliament, which, according to Mill, is even worse than having no voting rights at all ${ }^{426}$. Ultimately, it is party elites who decide who gets into parliament, because it is those elites who draw up electoral lists, and individuals with views typical of their parties always make the top of those lists. Thus, it is representatives advocating opinions which do not necessarily prevail among the people who wield actual power in the state. Moreover, these opinions are usually expressed by mediocre and obscure individuals, as only such people do not provoke any emotions among the voters, who vote for them routinely, without conviction, claims Mill, recalling the example of the United States ${ }^{427}$.

424 Mill believes that this is precisely what unenlightened peoples fail to understand, as they abhor obeying orders; cf. Mill, Considerations, p. 83.

425 Mill, Considerations, p. 133.

426 Cf. Mill, Considerations, p. 133-134.

427 That is why, Duff Spafford claims that, according to Mill, true representation has a purely direct character after all. Mill's objective is to design a form of government that will turn representative democracy into a kind of direct democracy involving delegates; cf. Duff Spafford, 'Mill's Majority Principle,' Canadian Journal of Political Science, Vol. 18, No. 3 (1985), p. 602-606. 
That is why, Mill resolutely advocates a proportionate electoral law. He summarises with enthusiasm Thomas Hare's proposal (applied to this day in a modified form), in which he finds an institutionalisation of his ideas 'in a manner approaching to ideal perfection' ${ }^{\prime 228}$. According to this electoral law, voters, with two votes at their disposal, cast them for a specific individual, not only for a party, from party or independent lists announced across the country. Additionally, they list candidates in order of preference; the vote goes to the first candidate, and once he reaches the limit necessary for his election, it moves on to the next one. Consequently, this method, Mill argues, ensures both proportionate representation and the election of specific individuals to a representative body. It ensures that many more citizens have their true representatives in parliament, i.e. the ones they have voted for, and who, thanks to their status, gain more importance in their party. For the weakness of democracy with a majority electoral law lies in the fact that it is largely a partiocracy, or rule by party elites.

In point of fact, unlike present-day advocates of proportionate electoral laws, Mill does not seek to guarantee that the electoral law ensures a variety of opinion in parliament, i.e. increases the representativeness of the representative body. What it should do is ensure the presence of the educated minority, the society's intellectual elite, in parliament. About other minorities he only writes that their members have the same right to organise themselves as the dominant majority ${ }^{429}$. Thus the ultimate advantage of proportionate representation is to prevent a marginalisation of that special minority, as in American democracy, known to him from de Tocqueville's work. In his enthusiasm over that method of election of representatives of the public, Mill even goes as far as claiming that if it had been known to the founding fathers, they would undoubtedly have enshrined it in the Constitution, because it is only this method, and not a majority electoral law, that ensures representation in accordance with the ideal of democratic equality ${ }^{430}$.

The representatives who would be returned to Parliament by the aggregate of minorities, would afford that organ in its greatest perfection. A separate organization of the instructed classes, even if practicable, would be invidious, and could only escape from being offensive by being totally without influence. But if the elite of these classes formed part of the Parliament, by the same title as any other of its members by representing the same number of citizens, the same numerical fraction of the national will - their presence could give umbrage to nobody, while they would be in the position of highest

428 Mill, Considerations, p. 139.

429 Cf. Mill, Considerations, p. 158-159.

430 Cf. Mill, Considerations, p. 146. 
vantage, both for making their opinions and counsels heard on all important subjects, and for taking an active part in public business ${ }^{431}$.

Obviously, the presence of the educated minority in the representative body does not in itself guarantee the rule of the intellectual elite. The representatives of the uneducated majority may always outvote it and continue to rule supreme; it is probably not an accident that Mill does not touch upon the matter of voting at all. However, as decisions are made in this way, it becomes crucial to change the opinions of members of the representative body before the vote. This is the place for classical deliberation: a debate of representatives on the common good; if ultimately each of them upheld his original opinion, the procedure would be pointless. But does the representative's status in Mill's project actually allow for deliberation? Does one not occupy one's seat in Parliament precisely not only to present, but actually to push through an opinion that has won the voters' approval? And while in the case of a majority opinion a change in the standpoints of several MPs could make no difference, losing even one minority representative may cause the absence of a minority opinion at that forum. Bearing in mind Mill's justification of proportionate representation, one would expect him to stress in particular the representatives' being bound by the opinions of the represented; however, the deliberation of the representative body on the common good requires precisely the opposite. Ultimately, the institution of representation may express either a diversified public opinion - and in that case there is no place for deliberation in parliament (given that MPs are bound by the opinions of their voters) - or a public opinion enlightened by deliberation - but in that case a diversity of opinion will only be a transitory stage in the decision-making process.

Advocating a proportionate electoral law, Mill justifies it with both diversity of opinion and the need for representation of enlightened opinion; that is why, his position on the issue must be ambivalent. For, on the one hand, he claims that the voters cannot demand from the representative not to change his opinion if he is persuaded of the soundness of another one; however, if they do not trust him, they may demand an explanation as to why he changed his opinion. On the other hand, the representative himself, even if he had abilities and an 'acknowledged eminence of character', should not underestimate his voters' opinions, even if he believes them to be mistaken. Characteristically, Mill sees that problem exclusively in terms of the truthfulness of opinions, and not the loyalty of the representative to the represented:

431 Mill, Considerations, p. 150-151. 
A man of conscience and known ability should insist on full freedom to act as he in his own judgment deems best; and should not consent to serve on any other terms. But the electors are entitled to know how he means to act; what opinions, on all things which concern his public duty, he intends should guide his conduct ${ }^{432}$.

Ultimately Mill argues against any formal limitations being imposed upon the representatives, but not unconditionally. Generally, he does not give any unconditional rules, but his very hesitation on the matter shows that he does not expect an undisturbed, purely rational deliberation from the representative body.

By no means does he assume, even though that idea is smuggled in rather than clearly expounded, that the proceedings of that body will be a debate of equal representatives, elected by equal citizens, restricted only by the laws of logic and the objective state of affairs. For the representative body consists of unequal individuals. An overrepresentation of enlightened individuals is not brought into parliament for their opinion merely to counterbalance the opinion of the unenlightened:

The representatives of the majority, besides that they would themselves be improved in quality by the operation of the system, would no longer have the whole field to themselves. They would indeed outnumber the others, as much as the one class of electors outnumbers the other in the country: they could always outvote them, but they would speak and vote in their presence, and subject to their criticism. When any difference arose, they would have to meet the arguments of the instructed few, by reasons, at least apparently, as cogent; and since they could not, as those do who are speaking to persons already unanimous, simply assume that they are in the right, it would occasionally happen to them to become convinced that they were in the wrong. As they would in general be well meaning (for thus much may reasonably be expected from a fairly-chosen national representation), their own minds would be insensibly raised by the influence of the minds with which they were in contact, or even in conflict ${ }^{433}$.

This long quotation says clearly that the common good is not defined through deliberation, but also shows how vague and difficult it is to define the procedure. In a good democracy, representatives of the uneducated majority, encouraged to reason freely, would ultimately have to recognise the educated minority's arguments and change their minds. Mill does not leave any doubts: as the biggest advantage of representative government is that the wisest people rule the state, while the decisions are made by the majority, a true democracy differs from a false one in the fact that a minority is able to persuade the majority to accept its opinion, and not that the majority outvotes a minority.

432 Mill, Considerations, p. 234.

433 Mill, Considerations, p. 147. 
Does Mill, therefore, have no other choice except to agree with Rousseau that, thanks to the institution of representation, democracy necessarily turns into an elective aristocracy? The answer depends on whether we regard persuasion, without manipulation, as a form of power, the way the advocates of the aggregate $^{434}$ idea of the common good do, or not, as the advocates of deliberation assume. Mill naturally belongs to the latter, but he would not insist that the state he presents is a democracy ruled by the majority. It was probably not an accident that he titled his treatise Considerations on Representative Government, and not, e.g., Considerations on Representative Democracy.

The system he designed is intended to prevent two forms of tyranny: the classical tyranny of an individual and the tyranny of the majority proper to the democratic era. By means of proportionate representation, the system is to prevent the emergence of 'two states', something Plato warned against in his greatest work. In Mill's state, the higher and lower classes meet in parliament in the persons of their representatives in order to address the affairs of the state together. They do not negotiate their interests or work out common positions, however, but let themselves be persuaded to accept the opinion of the intellectual elite, a minority free from class prejudices and particular interests. This elite, however - and this is what distinguishes it from Plato's philosophers - not being a closed caste, is part of the people. In any other political system, it would live on the margin of society; in this one, thanks to a peculiar form of representation, it takes its place at the helm.

For Mill does not doubt that in the course of debate, the enlightened minority will be able to persuade the uninstructed majority to adopt its opinion. For there is progress in history and it occurs precisely, thanks to minorities; today's majorities are nothing but yesterday's minorities. Thus, Mill's system serves a much more ambitious goal than the mere protection of minorities, and even if protection of minorities were its main goal, it fulfils this in the perverse way invented by Plato: his philosopher need not fear the polis only if he is its ruler. Once he comes into power, his reason does not allow him to use it except in the interest of the community.

Unlike in Plato's Republic, in Mill's state such reason is not the property of any particular category of individuals, though not everyone makes the same use of it. All citizens should debate on the affairs of the state, but decisions are made only by those who have the most reason, and the others should accept that.

434 Cf. Adam Przeworski, 'Deliberation and Ideological Domination,' in: Deliberative Democracy, ed. Jon Elster (Cambridge: Cambridge University Press, 1998), p. 140. 
Thus deliberation takes place in society, and the political system is to bring the intellectual elite to power. This is where the fundamental contradiction in Mill's project lies. For he seems to see a society ripe for representative government as a kind of debating society whose members do not so much learn how to rule a state as enjoy the exchange of arguments for its own sake. Why, however, to express it in an Aristotelian fashion, would 'many' like to discuss public affairs, even though decisions are actually made by only 'a few' ${ }^{435}$ ? The so-called ordinary citizens, who have not read Aristotle, will simply regard deliberation as nothing but empty chatter.

\section{Representation of the common good: representativeness in the representative body and a deliberating elite}

Unlike the authors discussed in the preceding chapters, Burke and Mill, not to mention Rousseau, of course, no longer invoke the idea of representation in order to constitute a government; they only want to use it to justify the choice of proper individuals to exercise power. The will of the ruled is to be the formal title to power, and personal qualities of intellect and character are an informal one. These qualities do not matter, in a sense, if all that is required of the representatives is for them to follow the instructions from their voters and thus aggregate the good of the community as a whole; they turn out to be of crucial importance, however, if there is no way this good may be reduced to particular goods and it must be defined by means of deliberation.

Thus, the choice of procedure for determining the common good entangles the idea of representation in two fundamental disputes which are settled by way of its institutionalisation. The first one, on the autonomy of representatives from the represented, is to a greater degree associated with deliberation; the other, on the degree of representativeness of the representative body in relation to the community itself, is more strongly associated with the aggregation of the common good. At first, the standpoints of Burke and Rousseau in these disputes seem evident: they decidedly opt for one or the other; nonetheless, when they give an institutional shape to their choices, they must also incorporate the solutions that they strongly criticise. By contrast, Mill's position is openly ambivalent and

435 In Hardin's opinion, this is the belief of Mill himself, so it is wrong to attribute to him the patronage of present-day concepts of deliberative democracy; cf. Russell Hardin, 'Representing Ignorance,' Social Philosophy and Policy, No. 21 (2004), p. 88. 
it also best illustrates the paradox of representation in the context of the procedural idea of the common good.

On the question of the autonomy of representatives, it is Burke who advocates the most extreme opinion, openly presenting it to the people of Bristol. The members of the representative body must be completely autonomous from their voters, for even if they won their seats in parliament with their votes, they represent the entire nation living within state borders. For a state is an organic whole, and thus its general interest cannot be an ordinary sum of the interests of its constituent parts, negotiated by a 'general congress of the ambassadors'. Representatives of the whole must be elected, however, for a rejection in the next election is practically the only way to call them to account. Otherwise the autonomy of the representatives will turn into impunity, as shown by the rule of the East India Company in an informal British colony. Thus, the election of representatives practically limits their autonomy, but it need not clash with the logic of deliberation, provided that those who make the choice call those elected to account over their service to the country, if only in their own interest.

In his Considerations, Rousseau sees only one way to exact accountability from the ruled: binding the delegates to the general diet with instructions from provincial dietines. To Rousseau, any form of autonomy of the representative body is nothing but a source of the government's corruption. The obligatory mandate of the delegates of provincial dietines seems to lead to defining the common good as a sum of interests of individual provinces, but Rousseau absolutely precludes such a procedure. The diet is to define the common good of the whole state; even if the state is only a federacy, decisions must be made in accordance with the procedure followed by the head of the republic. Even though for that form of the state voting by entire provinces would be the obvious form of decision-making, each delegate votes individually, gaining enough autonomy to be able to cast a vote against the standpoint of the dietine. Even so, will not its members be understanding to him, being certain that he has done so for the common good of the country as a whole, rather than in his own interest ${ }^{436}$ ? It is not an accident that Rousseau attaches so much significance to bringing up children in the spirit of patriotism.

436 Without supporting aggregation, Andrew Sabl argues, however, that it is in the common interest for representatives of a diversified society to fulfil their obligations to the represented consistently and loyally, even if not each manifestation of particularism deserves to be respected; cf. Sabl, Ruling Passions, p. 8-9, 25, 45-46, 137-138. 
In Mill's project, the accountability of the representatives before the represented is to be exacted not only by regular elections held every three years, but also by the permanent pressure of a society living with politics on an everyday basis. Societies ripe for representative government endow the rulers with trust and grant them autonomy, but monitor their actions all the time, and that is something that neither Burke, nor even Rousseau, demands from the ruled. The autonomy of the government has its ultimate justification in the self-interest of the ruled and the rulers' personal authority; Mill does not invoke the interests of the state as a whole; nevertheless, the very idea of long-term interests common to all people allows the representatives to act ignoring the short-term interests of their immediate authors. It is only the intellectual elite that deserves that privilege and only when it owes its position to election by the people. For it is impossible to impose a rule on a civilised society without stripping its members of their fundamental freedoms, even if doing so would benefit them. However, is not Mill overly optimistic when he believes that a society, even an enlightened one, is able to distinguish between demagogues and their true leaders?

The other controversy discussed above concerns the relations between the representative body and the community that elects it. On this point, Burke's opinion is the clearest. As the state is an organic whole, it is not important how many representatives are elected by its individual parts, provided that those representatives think in terms of the common good. Thus each member of the representative body represents not only the community as a whole, but also all its complexity, which brings into question the need to increase the representativeness of its delegation. However, the representatives of the entire nation belong to more or less formalised political parties; consequently, are they able to pursue 'practical philosophy'? The party character of the parliament by no means increases its representativeness, but it puts group interests on the agenda, which in turn makes one think of the common good in terms of its aggregation. Burke rejects that procedure, but he can do so only because, even though he regards the presence of political parties in parliament as obvious, he sees them as representations of general ideas and comprehensive political programmes, rather than particular interests.

Similarly, the idea of representativeness is completely alien to Rousseau, because he opposes deriving the common good from particular goods no less strongly than Burke. A reformed Poland is to be a federal republic not only because it is a heterogeneous state, but also so that all citizens may be involved to some degree in ruling the state, directly, not through their representatives. That is why Rousseau is unable to prevent particular goods from appearing on the agenda of the general diet; for what else are the resolutions of the dietines 
submitted for debate in the general diet? They are the general wills of the dietines, but in the national forum each is a particular will ${ }^{437}$. Instructions for MPs are to prevent the delegates from making decisions in their own interest; even so, they will impede rather than facilitate arriving at decisions conducive to the good of the state as a whole. The political system presented to the Poles is meant, most importantly, to prevent the evil of corrupt government, which has its source in the very size of the state; the Poles owe their love of freedom to their customs, and... to having imperial Russia as its neighbour.

To judge by his declarations, Mill must regard representativeness as a principle of fundamental importance to representative government. A democracy is false if minorities do not have representation elected directly by them in the representative body. This is not to say, however, that decisions made by the representative body must take into consideration minority opinions proportionately to the importance of those minorities in society; they need by no means take diversity of opinion into account at all. Representativeness concerns exclusively the composition of the representative body and does not guarantee everyone's participation in decision-making. For irrespective of the form of government, the rulers should be intellectually superior to society and make decisions benefiting it, even if such decisions are contrary to the short-term interests of its members. Mill seems to assume that the qualities of character and intellect will distinguish the intellectual elite to a degree that will make the other members of the representative body look up to it like pupils to their teachers; and pupils do not talk with their teachers as equals. If, therefore, the whole decision-making process proceeded according to Mill's wishes, it would be closer to Socratic maieutics than to Aristotelian deliberation.

However, the idea of representative government does not allow Mill to leave complete freedom to the elite, as the logic of deliberation would require; in accordance with the logic of aggregation, he forces those elected to take the opinions of the represented into consideration. This already happens at the election of the representative body, provided that it is allowed by a proper, i.e. proportionate, electoral law. Even if specific individuals exercise power because of their personal qualities of intellect and character, government is appointed by the will of the ruled, so the special competences of the rulers must be recognised by the ruled. Mill's ideal is the rule of an intellectual elite elected by the will of judicious people: rule by the will of the nation, exercised for the enlightenment of

437 This matter will be further discussed at the beginning of the following chapter. 
the people. The nation must allow an elite to lead it, and this is precisely what an enlightened people does.

Thus, it is in Mill's idea of representative government that the paradox of representation in the context of the common good becomes most evident: depending on the adopted procedure for defining the common good, relations between the representatives and the represented and the representative body and the political community differ so widely that, in terms of the classical political theory, one of these procedures sanctions the rule of 'many', while the other merely of 'a few'. In extreme cases, aggregation requires a representativeness of the elected body and an obligatory mandate, while deliberation requires the autonomy of representatives thinking exclusively in terms of the good of the whole. A government which follows only the deliberation procedure, a government of a peculiar aristocracy, may lack democratic legitimacy; a hyperdemocratic government only aggregating the common good from private interests may, on the other hand, become paralysed by its inability to reach a consensus. That is why the representative government must be guided by both procedures in so far as they are not sharply in opposition, while the citizens should leave their representatives a certain margin of freedom for actions contrary to their own private interest, provided that it is their belief that these representatives are promoting the common good. 



\section{Representation and social diversity}

\section{Social diversity as a problem of political institutions}

The rejection of the organicist vision of society, which marks modern political philosophy, by no means inevitably leads to atomism, attributed already to Hobbes. A 'multitude' of individuals, even if it is a society by virtue of convention only, produces a variety of communities within its limits, some of which may be as lasting as estates, while others are as changeable as associations. In fact, society is a veritable patchwork of communities, and some of them turn out to be important enough to their members to impart to them a collective identity. However, Rousseau, with his concept of general will, sees a major political problem in this apparently natural ontology of social life. In Political Economy, he argues:

It is all these tacit or formal associations which in so many ways modify the appearance of the public will by the influence of their own. The will of these particular societies always has two relations; for the member of the association, it is a general will; for the large society, it is a particular will, which very often proves to be upright in the first respect, and vicious in the second. A given person may be a devout priest, or a courageous soldier, or a zealous lawyer, and a bad citizen. A given deliberation may be advantageous to the small community, and most pernicious to the large one $e^{438}$.

Even if we do not agree with Rousseau's conclusions, the discovery of the diversity of individualistic society by the author of Political Economy reveals a weakness of representative government that is by no means obvious when one regards the government as the guardian of the common good. For while in this case a corrupt government, pursuing its own interest, becomes alienated itself, what one tends to see from the perspective of social diversity is, rather, its partiality, and, consequently, the exclusion and ultimately alienation of that part of society which does not have its representatives in a body allegedly representing it. The fundamental problem of the pluralistic current of political thought is therefore how to institutionalise the idea of representation so as to ensure that this variety of interests and identities is properly reflected in the political system. The point is not only to select a proper electoral law, because behind each electoral law there is a certain general vision of relations between the fabric of society and government bodies.

438 Jean-Jacques Rousseau, 'Discourse on Political Economy', in: The Social Contract and Other Later Political Writings, ed. Victor Gourevitch (Cambridge: Cambridge University Press, 1997), p. 7. 
James Mill's and George Douglas Howard Cole's concepts of representative government ${ }^{439}$ discussed in this chapter illustrate two extreme approaches to the problem. In the former case, institutions of representation transfer to the political system only that which is common to all members of a diversified society; in the latter, they reproduce that entire diversity in unique institutions of functional representation belonging to society itself. On the other hand, the concept of civil society derived from Alexis de Tocqueville's Democracy in America presents a solution that is an alternative to the two mentioned above, because it presupposes multiple institutions of representation, located both within the system of government and in the civil society influencing it. It is precisely in the sphere of civil society, absent from the two former attempts at designing a representative system, that the paradox of representation in regard to social diversity reveals itself.

From Rousseau's perspective, such smaller and diverse communities, each with its own particular group will, serve only to interfere with a truly general will, i.e. the will of the whole political community of citizens, being defined. In Jeremy Bentham and James Mill's utilitarian vision of representative democracy, presented most lucidly in the latter philosopher's Essay on Government ${ }^{440}$,

439 George Douglas Howard Cole is an author little known outside the UK; together with Harold Laski and John Neville Figgis, he belongs to the specifically British antietatist strain of socialism, which they named guild socialism. While Guild Socialism Restated is a most representative publication for that milieu, it is The Social Theory that deserves attention in the context of the present work, as it proposes a concept of functional representation alternative to Bentham's. The British pluralists owe the increasing interest in their theory to the books of Paul Hirst, who, inspired by their works, developed a theory of a state based on voluntary associations. None of Cole's books has been translated into Polish as yet, and the only fairly exhaustive exposition of that milieu's views is Marcin Tobiasz's doctoral dissertation Etatyści czy pluraliści? Dylematy brytyjskiej lewicy w pierwszej połowie XX wieku (Warszawa: Dom Wydawniczy Elipsa, 2010). It is worth noting that the 19th- and early 20th-century Polish thinker Edward Abramowski propagated similar ideas in Poland; however, his theory lacks the key concept of the present work, i.e. functional representation; besides, it is naturally involved in the issue of national liberation.

440 Like Bentham's disciples themselves, historians of political philosophy do not see any major differences between these two authors, which is hardly surprising, considering that James Mill was actually more of a propagator of Bentham's theory than an original thinker; cf. Crawford B. Macpherson, The Life and Times of Liberal Democracy (Oxford - New York: Oxford University Press, 1977), p. 25; Anthony Harold Birch, Representation (London: Macmillan, Pall Mall Press, 1977), p. 55. However, this opinion is not shared by Frederick Rosen, who discusses in detail all the differences between Bentham and Mill; cf. Frederick Rosen, Jeremy Bentham and Representative 
that problem, characteristically, does not appear at all, as to utilitarians, sociological nominalists, social diversity is exclusively a diversity of individual traits. Individual membership, both voluntary and imposed, of various social groups, ultimately expresses itself in their individual identities and individual preferences. On the other hand, Cole's concept of pluralistic democracy - organisation of social life based on voluntary associations, capable of functioning without a state or civil society ${ }^{441}$ - may seem extravagant enough today that it is no wonder Rousseau is the authority to whom its author turns for support. Cole has, however, to present a 'different' Rousseau, arguing that the essence of his philosophy is not the general will but active citizenship. As is evident from the previous chapter, only such a Rousseau is not in principle opposed to representation per se; he is only opposed to the kind of representation which transfers sovereignty from the principal to the representative; for the author of the Social Contract, Cole rightly argues, did not reject representative government, but representative sovereign power ${ }^{442}$.

In Alexis de Tocqueville's work, Rousseau's name is not mentioned, but its readers cannot doubt that a democracy that the author of Democracy in America fears resembles the republic described in the Social Contract. However, the American republic is not a state ruled by Rousseau's mystical general will; fortunately, power is exercised there by citizens who are guided by 'habits of the heart', and not by the severe laws dictated by Reason in public life.

Democracy. A Study of the Constitutional Code (Oxford: Clarendon Press, 1983), p. 168-182. David Runciman and Mónica Brito Vieira point out that Bentham was suspicious of the institution of representation, seeing it as more of a problem than a solution; cf. Runciman, Brito Vieira, Representation, p. 46.

441 In The Social Theory Cole emphasises that the idea of functional democracy must not, on any account, be reduced to a demand for a second house composed of representatives of chosen professions to replace the House of Lords (p. 102). I have consulted the extensive fragments of this book included in Paul Hirst's anthology: Paul Q. Hirst, ed., The Pluralist Theory of the State. Selected Writings of G. D. H. Cole, J. N. Figgis, and H. J. Laski (London - New York: Routledge, 1989). The anthology in question is worth consulting, as it offers an authoritative overview of the opinions of that milieu.

442 Cf. George Douglas Howard Cole, 'Rousseau's Political Theory', in: Essays in Social Theory (London: MacMillan \& Co. Ltd, 1950), p. 120-124, 131. According to Cole, Rousseau's ideas have been distorted by replacing, against his explicit views, sovereignty of the people with sovereignty of government and assuming that an elected body gains the attribute of sovereignty by virtue of the act of election itself. Cole has to admit, however, that the idea of a sovereign people is open to similar abuse. 
What one understands by republic in the United States is the slow and tranquil action of society on itself. It is a regular state really founded on the enlightened will of the people. It is a conciliating government, in which resolutions ripen for a long time, are discussed slowly and executed only when mature ${ }^{443}$.

Regarding democracy as a peculiar, new type of society, de Tocqueville does not pay much attention to government institutions. When he explains the way they operate he usually invokes the Federalist Papers. Basically, they function in accordance with social expectations; thus, the institution of representation is an integral part of public life, just like other institutions of a self-governing society. This is one of the things that distinguish the American republic from the French republic, whose political system still cannot put down roots in society.

\section{Representation of representative interest: James Mill's Essay on Government}

Even if society in utilitarian philosophy is nothing more than a collection of individuals, this does not mean that according to Bentham and Mill the public good is a sum of individual goods. As these goods compete with one another and abolish one another, it is not possible to define the common good by aggregating individual goods one way or another, just as it is not possible to define it in Rousseau's manner, i.e. in opposition to individual goods, even if the contradiction between them is evident ${ }^{444}$. One individual's good is worth as much as any other's; thus each vote should count as one and one only. Considering that people are selfish, and even altruistic acts are in accordance with their interests, how can the rulers, seeking their own good, act in the interest of the ruled? James Mill finds a solution to that problem in the idea of representativeness, not, however, in its present-day sense: power should be vested in a category of citizens whose private interest would be in accordance with the general interest. For the government, according to a belief the utilitarian philosophers had taken over from David Hume, will always rule in its own interest. Thus, the political system should be designed in such a way as to ensure that those who are to wield power

443 Alexis de Tocqueville, Democracy in America (Chicago and London: The University of Chicago Press, 2002), I, Part Two, Chapter 10, p. 379.

444 In his Codification Proposal Bentham argues that it is necessary to the greatest happiness of the greatest number that a part of the happiness of an individual be sacrificed. This issue is elaborated on by Tomasz Tulejski, Od zasady użyteczności do demokracji. Filozofia polityczna Jeremy Benthama (Łódź: Wydawnictwa Uniwersytetu Łódzkiego, 2004), p. 143. 
collectively elect to the representative body people who will discharge this task best; the election of delegates from the representative category is itself a matter of secondary importance. Utilitarians do not ask about the origins of the institution of government itself, but exclusively about its legitimacy: government exists in one form or another, because people draw major, specific and indeed calculable benefits from its existence ${ }^{445}$.

Proceeding from abstract principles to historical realities, they first reject any form of balanced government, as they question the possibility of creating a lasting balance and harmony between social interests, represented by various government bodies. Mill does not refer here to Montesquieu's doctrine, however, but rather, like Bentham, to William Blackstone's Commentaries on the Laws of England (without quoting the title). He considers the doctrine presented in it to be misjudged and unrealistic. His argument is very simple: if there are three powers, one cannot prevent two of them uniting in order to 'swallow' the third one $^{446}$. Accordingly, in a mixed system of government, such as the British one, the people does not have enough power to oppose the monarch and aristocracy; despite representation, in the system of government the largest group in society has no institutional protection of its interest.

Thus, pursuing the doctrine of maximum happiness for the greatest number of people requires concentrating power in the hands of a single representative body, a legislative. That body is the sovereign, but only in the sense, i.e. has no other above $\mathrm{it}^{447}$. Utilitarians make two requirements concerning it: it should have 'a degree of power sufficient for the business of checking' and 'an identity of interest with the community', i.e. it should not use its power in a way detrimental to $\mathrm{it}^{448}$. It must have enough power to effectively act on behalf of the represented, but not enough to liberate itself from their control. Consequently, Mill sets short,

445 Cf. Jeremy Bentham, A Fragment on Government (Cambridge: Cambridge University Press, 1992), p. 55.

446 Cf. James Mill, 'Essay on Government', in: Political Writings (Cambridge: Cambridge University Press, 1992), \$69, p. 20.

447 Herbert Lionel Adolphus Hart notes that Bentham excludes all formalised limitations of power, relying on 'the subjects' disposition to obey' [Herbert Lionel Adolphus Hart, Essays on Bentham (Oxford: Clarendon Press, 1982), p. 231], but even though he openly rejects the possibility of competent courts appealing against each act of parliament, he eventually admits that it is courts that may limit the legislative's absolute power, 'though in a looser popular usage the legislator would still be described as Sovereign.' H. L. A. Hart, Essays, p. 240.

448 Cf. Mill, 'Essay,' $\$ 73$, p. 22. 
barely one-year-long terms for the members of the legislative, which, however, may be repeated without limitation by the will of the voters ${ }^{449}$. Such a solution is supposedly enough to prevent alienation of government.

Despite methodological individualism and egalitarianism, the election of the representative body itself is dictated by the logic of the public interest, rather than individual interests. Even though the object is to elect people with sufficient 'mental qualities', considering how difficult it is to examine the entire population in this respect, one has to rely on 'outward and visible signs ${ }^{2450}$. Characteristically, James Mill seems to assume that representatives will be guided by the public interest not because they have been elected from among a given category of individuals, as John Stuart Mill claimed in the treatise discussed in the previous chapter, but because they have been elected by that category. One might say that he wants to ensure that those relatively few citizens who ultimately, after all the exclusions to be discussed below, elect the government, are unable to elect it otherwise than in accordance with the public interest.

It is very evident, that if the community itself were the choosing body, the interest of the community and that of the choosing body would be the same. The question is, if that of any portion of the community, if erected into the choosing body, would remain the same ${ }^{451}$ ?

One thing is clear enough that all individuals whose interests are evidently included in the interests of other individuals may very easily become excluded. In the first step towards narrowing down the electorate without detriment to its representativeness, Mill excludes women and children, leaving men in the role of representatives of society at large. Subsequently, from among adult men over the age of twenty-one, he selects only those over forty; for the older generation looks after the interests of those below that age limit (sic! $)^{452}$.

In this context, most of the controversy will inevitably centre on the property qualification ${ }^{453}$. It should not be so high, Mill argues, as to constitute an aristocratic government; however, if it were too low, those who possess nothing would also be represented by the government. And this is precisely what the possessing

449 Cf. Mill, 'Essay;' $\$ 88$, p. 26.

450 Cf. Mill, 'Essay,' $\$ 99$, p. 27.

451 Mill, 'Essay,' $\$ 95$, p. 27.

452 Cf. Mill, 'Essay,' \$ 101, p. 28. Rosen invokes Bentham's manuscript, in which he criticises Mill for a high age limit; cf. Rosen, Jeremy Bentham, p. 169.

453 Bentham also excludes illiterates, debtors and generally people financially incapable of living independently; Tulejski discusses this point in detail in Od zasady, p. 212-218. 
classes fear: to them, universal suffrage means the abolition of the property right; Mill shares these fears, arguing that the institution of private property benefits all ${ }^{454}$. People not in possession of real estate should also have their representation, the kind of representation that can express their true interest, i.e. the maintenance of the property right, and not their short-term interest, which is contrary to the interest of society as a whole, i.e. its abolition. Unlike the higher social classes, the representation of that class of individuals is meant only to make it present in the representative body. For this reason, there is no question of representativeness of the representative body in the full sense of the term, a fact that Mill by no means disguises.

For if the whole mass of the people who have some property would make a good choice, it will hardly be pretended that, added to them, the comparatively small number of those who have none, and whose minds are naturally and almost necessarily governed by the minds of those who have, would have any chance of making the choice a bad one ${ }^{455}$.

After considering gender and age, the property qualification is the final criterion by which the proper category of representatives of the public interest is chosen. Neither profession nor lifestyle, Mill argues, should be taken into consideration in the election of a representative body; if they were, it would lose its representativeness. For the representativeness of the representative system is achieved by means of an election of government by a representative category, rather than by virtue of representation of individual categories in that body. Advocates of mirror representation in political institutions (misguidedly) invoke the concept of 'virtual representation' of which Burke wrote; Mill decidedly rejects representation in that sense:

Three, or four, or five, or more clubs of men, have unlimited power over the whole community put into their hands. These clubs have, each, and all of them, an interest, an interest the same with that which governs all other rulers in misgovernment, in converting the persons and properties of the rest of the community wholly to their own benefit ${ }^{456}$.

As a result of that 'motley Representation', an assembly of 'motley Aristocracy' comes into being, incapable of cooperation, which, even if it does not oppress that part of society which did not elect it, necessarily pursues an inconsistent policy promoting group interests, guided by its unique esprit de corps. There is no question here of any deliberation serving 'virtual representation'. The representative

454 Cf. Mill, 'Essay', \$ 106-107, p. 29-30.

455 Mill, 'Essay', \$ 105, p. 29.

456 Mill, 'Essay', $\$ 115$, p. 33. 
body should draw all the knowledge necessary for running state government from society itself, as this knowledge is nothing but proper appreciation and understanding of one's own interest ${ }^{457}$.

Thus, what remains a contentious issue is only whether society itself has adequate knowledge about its own interests, i.e. whether the utilitarians are right in assuming that every (mature) individual is the best expert on what constitutes his own interest. The belief that it is not so, Mill argues, has its source in religion, the Catholic doctrine limiting free access of the laity to the Bible, and this has no justification whatsoever in the political domain. In any case, even if people were indeed incapable of properly recognising their own interest, it is still better for the state when the government is guided by a majority interest, even if it should be misconceived, than by the interest of a privileged minority ${ }^{458}$. In Bentham's time, the aforementioned privileged minority is the House of Lords; Bentham mocks the supposed wisdom of its members, free from pecuniary worries and for that reason allegedly predestined to rule the state: if that house had as many members as the House of Commons, and the latter as few as the House of Lords, they could even change places in the constitutional order ${ }^{459}$ !

When we take into consideration the selection criteria for the category representative of social interest, it should come as no surprise that Mill's Essay on Government concludes with a commendation of the middle rank, indeed in a short panegyric in which the author, like Aristotle in Politics, presents this class as the leading class of society as a whole ${ }^{460}$. It shapes public opinion - Mill even speaks of 'the principles of human nature in general' ${ }^{461}$ - and therefore it naturally has to be representative of society.

457 Cf. Mill, 'Essay', \$ 133, p. 38.

458 Cf. Mill, 'Essay', \$ 142, p. 40.

459 Cf. Bentham, A Fragment, p. 77-82. Utilitarians indeed opted for one legislative chamber, though in practice their demands were treated as a demand to strengthen the House of Commons and grant it competences equal to those of the House of Lords; cf. Timothy Fuller, 'Jeremy Bentham and James Mill', in: History of Political Philosophy, ed. Strauss, Cropsey, p. 727.

460 Some interpreters of James Mill's thought, including Terrence Ball, the editor of his works in 1992, argue, however, that by 'middle rank' Mill did not understand 'middle class'; cf. Shannon Stimson, Murray Milgate, 'Utility, Property, and Political Participation: James Mill on Democratic Reform,' American Political Science Review, Vol. 87 (1993), No. 4, p. 908, Footnote 5.

461 Cf. Mill, 'Essay', \$ 145, p. 41. 
There can be no doubt whatever that the middle rank, which gives their most distinguished ornaments to science, to art, and to legislation itself, to every thing which exalts and refines human nature, is that part of the community of which, if the basis of representation were now so far extended, the opinion would ultimately decide. Of the people beneath them, a vast majority would be sure to be guided by their advice and example ${ }^{462}$.

Except for possession of property, which in Mill's interpretation does not so much differentiate society as divide it into a politically active part, which organises representation for itself on its own, and a politically passive part, which is only represented, the representative body does not mirror any differences. Characteristically, the theme of general human nature recurs in Mill's treatise. For the power exercised by a category of individuals representative of society as a whole is meant to express that which is common to people with a variety of interests: it is in that and only in that sense that that government represents the general interest. Thus, what constitutes that interest will be decided by the opinion of the representative, i.e. in this context, of almost mediocre citizens, by their doxa, rather than by the episteme of the 'philosophers' claiming to possess special knowledge about the whole of the state.

In the British Isles, utilitarian philosophy came to be described as philosophical radicalism, because it opposed an egalitarianism that was alien to the existing political system; nevertheless, its theoretical revolutionary potential had to be limited by its very nature. Even if it justified a democratisation of the state in practice, it was only within the limits allowed by the idea of the common good, i.e. of the interest of the middle class underlying it, the class which by means of the institution of representation gains the status of a prevailing majority in the representative body. Despite the expansion of the general constituency, utilitarian government is not sensitive to minority interests contrary to the general interest thus defined; in the name of that interest, sanctioning majority rule, they must be ignored ${ }^{463}$. Tensions between the democratic majority principle and social pluralism will only become obvious once the property qualification is abolished and other dimensions of social diversity are gradually revealed, to which representative government has thus far remained indifferent. This is the subject of George Douglas Howard Cole's 1920 book The Social Theory.

462 Mill, 'Essay', $\$ 145$, p. 41.

463 This is not to say, however, that Bentham and Mill's scheme did not democratise the existing political system. As calculated by Stimson and Milgate, it gave voting rights to 10 per cent of the population of Great Britain and Ireland at that time, i.e. 2.1 million people, while following the 1832 reform such rights were enjoyed by seven times fewer citizens; cf. Stimson, 'Utility', p. 906. 


\section{The functional representation of associations: George Douglas Howard Cole's The Social Theory}

Drawing on Rousseau's heritage, Cole finds in it an assumption that, as he expressly states, is central to his own political theory: the will of one individual cannot be handed over to another. And if such is the case,

No man can represent another man, and no man's will can be treated as a substitute for, or representative of, the wills of others ${ }^{464}$.

Consequently, general and 'inclusive' representation is not possible; what is possible is partial and functional representation, when 'the representative represents not persons, but definite and particular purposes common to a number of persons ${ }^{365}$.

The representative is only delegated to perform, according to his best knowledge and skills, certain activities, which his electors could not perform equally well. However, they must offer him advice and criticism all the time; also, they may recall him at any time if he fails to meet their expectations ${ }^{466}$. This type of representation, Cole claims, is obviously not a power of attorney allowing the representative to act beyond the principal's control, even though he will shoulder the consequences of his decisions, but neither is it an obligatory mandate, limited by instructions issued once, which may paralyse any action. This kind of representation differs from ordinary representation in that it necessitates contact and cooperation between the representatives and the represented, and does not allow the former or the latter to deal with their own business.

Actually, the ideological justification for that type of representation is precisely that not only does it not replace active citizenship, but indeed it encourages $\mathrm{it}^{467}$. Laski will argue that, thanks to representation thus defined, it is also possible

464 Cole, The Social Theory, p. 83.

465 Cole, The Social Theory, p. 86. Without invoking Cole's theory, the contemporary authors John Dryzek and Simon Niemeyer, speak of the representation of a 'multiple self' and the institutionalisation of particular 'discourses', such as market liberalism, anti-globalisation, social democracy, etc., and subjecting them to the deliberation procedure; cf. John S. Dryzek, Simon Niemeyer, 'Discursive Representation,' American Political Science Review, Vol. 102 (2008), No. 4, p. 481-488.

466 Cf. Cole, The Social Theory, p. 87. They represent, as John Burnheim puts it, 'social experience, and it would be best if this function were performed by volunteers; cf. John Burnheim, Is Democracy Possible? (Cambridge: Polity Press, 1985), p. 118, 110.

467 Cf. Cole, The Social Theory, p. 89. Thus, Rousseau's argument that the modern people invented representation in order to devote themselves to multiplying goods does not apply here. 
to achieve Aristotle's ancient ideal in large states as well as small ones: that of a citizen who alternately rules and is ruled ${ }^{468}$. Obviously, Cole is aware that this institution will not ensure any dramatic rise in interest in politics, but even if it attracts only a handful of those committed, their informed participation is much more valuable than the mass uninformed participation that we have to do with in present-day democracy ${ }^{469}$.

For nothing destroys politics as much as party rule exercised high above the heads of ordinary people. Centralised party organisations do not mediate between society and the state; on the contrary, they contribute to the bureaucratisation and oligarchisation of social life as a whole; they destroy its naturalness and its spontaneity ${ }^{470}$. Nor has representative democracy performed well at the local level thus far, because local government is not an established institution as yet (in Great Britain in Cole's day and age) ${ }^{471}$. Nor is the division into the legislative and executive powers working at all, because the legislative delegates many of its prerogatives to administration; the biggest perversion of this kind is the cabinet government itself ${ }^{472}$. All of this justifies the need to thoroughly reconstruct the system, the need for institutional change instructed by a proper theory.

Unhappily, the old democrats, Jacobins and Benthamites alike, make a disastrous mistake in their interpretation of democracy. Their forerunners had wished to strip man naked before God, to throw off all the trappings of Church and sacrament in order to establish a direct and personal relationship between the individual and his Creator. The political democrats set out to strip the individual naked in his relations with the State, regarding all the older social tissue as tainted with aristocratic corruption or privileged monopoly. Their representative democracy was atomistically conceived in terms of millions of voters, each casting his individual vote into a pool which was somehow mystically to boil up into a General Will ${ }^{473}$.

468 Harold Joseph Laski, 'The Pluralist State', in: The Pluralist, ed. Paul Q. Hirst, p. 188.

469 Cf. Cole, The Social Theory, p. 90. Cole enumerates the reasons for a lack of interest in politics in 'The Essentials of Democracy'; see George Douglas Howard Cole, Essays, p. 111.

470 Cf. George Douglas Howard Cole, 'Democracy Face to Face with Hugeness', in: Essays, p. 94; George Douglas Howard Cole, 'The Essentials,' p. 101. Theoretically, parliament may be a place of debate, but political parties effectively suppress it, forcing discipline upon its members; cf. Harold Joseph Laski, 'The Problem of Administrative Areas', in: The Pluralist, ed. Hirst, p. 132-133.

471 Cf. Cole, The Social Theory, p. 94.

472 Cf. Cole, The Social Theory, p. 94-95. For a discussion of other weaknesses of representative democracy, see also Harold Joseph Laski, 'The Problem,' p. 136, and for discussion of the forces undermining it, see Cole, 'The Essentials,' p. 105.

473 Cole, 'Democracy', p. 92-93. 
Cole claims that obviously nothing like that has happened or could have happened; all it did is tear the individual out of his social environment. For, independently of the state, people have built trade unions, cooperatives and a variety of associations of their own will, and it is these bodies that create true democracy in society; however, governments do not understand that and, based on the atomistic theory of democracy, regard these communities as enemies of democracy.

A theory of functional democracy, a democracy founded upon functional representation, must therefore derive from completely different premises concerning social life and relations between it and political institutions. The richness of social life does not allow one to speak simply about society and the state; that man lives in society means that he lives in a variety of communities ${ }^{474}$. One should always start building democracy from the bottom up ${ }^{475}$. The state must not be the only democratic institution in society, for if that is the case, it will not remain democratic for long; citizens should begin their political activity by getting to know their neighbours, for it is with them that they will first practice active citizenship ${ }^{476}$.

In fact, Cole and other theorists of British pluralism go so far as to deprive the state of its unique place in society; ultimately, it is merely one of a number of associations. Admittedly, in his later writings Cole attributes to it a more important role, but in The Social Theory he does not even believe that the state needs to coordinate the actions of the associations, as they can do that themselves

474 Cf. John Neville Figgis, 'The Great Leviathan', in: The Pluralist, ed. Hirst, p. 126.

475 In Edward Abramowski's theory, the building of a social order based on associations is meant to lead to an abolition of the state, a partitioning state: 'It is only possible to eradicate the state with the help of associations; one kills it by cutting the roots out of which it grows, i.e. by pulling apart the bond between the people's needs and state institutions. A state that becomes practically unnecessary, that begins to be more and more superfluous to an individual's personal interests, that has been supplanted by associations in discharging tasks in economy and culture, defence and justice, health and education, such a state must die.' Edward Abramowski, 'Socjalizm a państwo. Przyczynek do krytyki współczesnego socjalizmu,' in: Edward Abramowski, Filozofia społeczna. Wybór pism (Warszawa: Państwowe Wydawnictwo Naukowe, 1965), p. 297-298.

476 Cf. Cole, 'The Essentials', p. 100. Burnheim even speaks of a conflict between the state and democracy, adding, however, that a weak state is only possible when society itself is strong enough; cf. Burnheim, Is Democracy, p. 39-40. 
collegially ${ }^{477}$. Ultimately, in its present-day form, the state is a historical organisation which emerged in response to the break-up of a certain type of political order, and for that reason it may disappear if society is able to guarantee order for itself in some other way ${ }^{478}$. Thus, in pluralist democracy there is no single representative body with the functions of the Hobbesian sovereign, nor any other to represent anything more important than one aspect of man's social condition. For that reason, nor is there in that type of democracy politics defined as in the Nicomachean Ethics, i.e. as the 'master art', having as its object the common good of the state as a whole, with particular goals subordinated to it.

As the social order is ultimately constituted by voluntary associations, collectively they will perform all the functions of the legislative and executive powers, having the individual right to enforce their decisions ${ }^{479}$. Each association must independently ensure that its functions are discharged; a council or congress, made up of representatives of the most important organisations, will merely coordinate their activities. People will form associations depending on their needs; Cole attaches special significance to workplace unions, regarding industry as the principal force shaping society at the beginning of the 20th century ${ }^{480}$.

Behind the vision of an order constituted by a wealth of associations, there is an idea that it has more than just a territorial dimension. According to Laski's famous formula, railways are as real as Lancashire ${ }^{481}$; hence, man creates that order not only as a resident of that county, but also as a potential railway passenger. In Guild Socialism Restated, Cole defined specific areas which should be included in functional representation so that their users, as producers or consumers, gain influence over them: not abstract influence over state affairs, but real influence over designated areas of social life. Cole refers directly to the utilitarian happiness calculation formula.

477 Cf. Cole, The Social Theory, p. 102-103. In Guild Socialism Restated, the state's functions are taken over by parishes, in Self-Government in Industry, by a congress made up of parliament and guilds; cf. Tobiasz, Etatyści, p. 117-118.

478 Cf. Cole, The Social Theory, p. 105. The state's monopoly on the use of coercion, notes Laski, does not appear until Bodin's conception of sovereignty; cf. Laski, The Pluralist, p. 184.

479 Cf. Cole, The Social Theory, p. 96-100. What is characteristic here is naturally a lack of a separate judicial power.

480 As Cole regarded the existing representative institutions as consumers' representation, functional representation was to express mainly producers' interests; cf. Tobiasz, Etatyści, p. 107.

481 Cf. Laski, 'The Problem,' p. 145. 
This does not mean that, in a functional democracy, each person will count for one and no person for more than one. That is the cant of false democracy. The essence of functional democracy is that a man should count as many times over as there are functions in which he is interested. To count once is to count about nothing in particular: what men want is to count on the particular issues in which they are interested. Instead of 'One man, one vote', we must say 'One man as many votes as interests, but only one vote in relation to each interest ${ }^{\prime 482}$.

Thus, the relationship between representatives and the represented in functional democracy differs diametrically from that which was discussed in the earlier part of this chapter. There, every member of the representative body could, due to his representativeness, be a representative of society as a whole; here, every member of society should be represented by at least several bodies, and, in particular circumstances, even by all, as each is in charge of vital social functions. Because of their social status, measured in terms of the number of matters they are interested in, particular individuals will accordingly be taken into consideration to a lesser or greater degree in the decisions of representative bodies.

Such a reformulation of the principle of democracy, Cole claims, does not mean negating the principle of equality, and allows those people who have gained an in-depth knowledge of particular areas of social life to achieve greater importance in those domains, provided that they are able to persuade others to accept their opinion. For leadership in democracy should consist in influencing others, encouraging them to make the right choices, not in gaining votes cast 'blindly' by voters.

If we define the state as an association of people with a distinguished political power holding a monopoly on violence, then in Cole's functional democracy it gets absorbed by society. A distinction between what is merely social and what transitions, by means of representation, into the political sphere, has become meaningless. Society's metaphorical victory over the state does not mean a domination of the social 'element', however, because it is constricted by the quasipolitical organisation of associations. In functional democracy, the order is not political, but neither is it natural; it has been institutionalised, and each institution has a right of coercion with regard to its members in one form of another ${ }^{483}$. Consequently, in functional democracy, coercion, even though dispersed, is ubiquitous, just like associations themselves. As membership in them may only be voluntary, functional democracy by its very nature borders on anarchy. Cole

482 Cole, The Social Theory, p. 89-90.

483 Cf. Cole, The Social Theory, p. 99. 
himself admits that every good democrat 'is a bit of an anarchist when he's scratched' ${ }^{384}$.

If, therefore, that particular type of democracy, a democracy without a state, corresponds to some kind of politics, it will resemble deliberation in the form presented by Aristotle in Politics. Unlike in the Greek polis, however, it is not possible to reserve a single distinguished place for it in present-day society; on the contrary, because of its pluralistic and egalitarian character, it should sink into the fabric of society as deep as possible.

I am suggesting that there ought to be for every street, or little group of streets, for every block of flats, and, of course, for every village and hamlet a regularly meeting, recognized, neighbourhood group, with a right to discuss and resolve upon anything under the sun. [...] Every new group of streets we build ought to have its little Moot Hall for such assemblies of its people, ought to have its little centre for their communal affairs. Personally, I think this Moot Hall should be also a communal restaurant and bakehouse, and a social club. I think it should include a place where children could amuse themselves, and be left in charge of somebody when their parents are away ${ }^{485}$.

Thus, politics defined as deliberation is to accompany the citizens in their everyday occupations; it is not that they will find time for politics after a day filled with work; it is that politics will be incorporated in every sphere of social life in which decisions crucial to society are made.

Pluralism of this kind is only possible because it is not threatened by the state with its claims to universality ${ }^{486}$. Pluralism can therefore be reconciled with democracy, but absolutely not with the state. However, is not that belief true only if one thinks about the democratic state as Rousseau does and regards any kind of social diversity as the source of particular wills, weakening its general will? Today, the conflict between the ideals of democracy and pluralism discussed at the beginning of this chapter seems to be more of a problem of democratic theory than of the democratic state. For in the tradition of democratic thought initiated by Alexis de Tocqueville, the democratic state itself is grounded in civil

484 Cf. Cole, 'The Essentials,' p. 98.

485 Cole, 'The Essentials,' p. 109.

486 As Hirst argues, a hierarchically organised state may, admittedly, gain democratic legitimisation, but it will not be democratically governed; cf. Paul Q. Hirst, Representative Democracy and its Limits (Cambridge: Polity Press, 1990), p. 75. However, Hirst does not go as far as Cole: a social order based on voluntary associations needs a state after all in order for it to prevent conflicts between them, as well as to protect their members against them; without the state, that order could even turn into a tyranny of associations (p. 78-79). 
society institutions and it is these institutions that constitute the pluralism which he extolls.

In Cole's project presented in The Social Theory, there is no place for civil society. From the perspective of non-etatist socialism, it does not guarantee social harmony; quite the contrary - it is the source of numerous conflicts and divisions, and does not allow the consequences of actions to be predicted ${ }^{487}$. Thus, pluralistic democracy based on functional representation is to replace both the state and civil society. Alexis de Tocqueville thinks about this in a completely different way: a democratic state must be part of civil society or it will not be a democracy.

\section{Representation of civil society: Alexis de Tocqueville's Democracy in America}

De Tocqueville mentions three important features in terms of which American democracy differs from the one created by his compatriots: firstly, activism of citizens in local communities; secondly, the associations they found to achieve shared goals; and thirdly, a lack of administrative centralisation despite a strong governmental centralisation. Each of them is equally important; it is only the subject of the present work that justifies ignoring local communities and a lack of centralisation and presenting the role of associations themselves as institutions

487 Cf. Hirst, Representative, p. 17, 65. Naturally, the attitude of contemporary socialists and pluralists towards civil society has changed considerably. Hirst writes: 'The most sophisticated forms of pluralism do not aim to abolish representative democracy and replace it by a new single system of functional democracy. Rather they aim to multiply representative bodies and to complement them by forms of functional representation of organized social interests. Pluralism, therefore, gives more room for organized means of influence, representing specific categories of citizens, and it increases the scope for interaction between public bodies and civil society. Pluralism offers a way for the state and civil society to interpenetrate, whilst restricting the scope of state power and its capacity to dominate civil society. Pluralism in this sense creates the space for an active civil society of associations freely formed of citizens and allows those self-governing associations to undertake a greater part of the tasks of social life' (p. 8). Hirst elaborates on these ideas in his book Associative Democracy. New Forms of Economic and Social Governance (Cambridge: Polity Press, 1994). John Burnheim also presents similar views in the cited work, without invoking, somewhat surprisingly, the ideas of British pluralists. As a result of civil society being included in the contemporary pluralist project, however, it loses the theoretical clarity which characterised Cole's project. 
of social representation in the political system. For it is they that constitute civil society; they constitute not only an active, but also an institutionalised part of society, and shape, either directly or in a roundabout way, the above-mentioned enlightened opinion. One may say that to de Tocqueville, civil society is a connection between society and the state; it would be completely misguided, however, to claim that it exists independently of the state ${ }^{488}$.

De Tocqueville does not even pose the question of whether representative government may be democratic; in egalitarian America the people rules by the very nature of things, as it were, and irrespective of the institutional order its will will be translated into practice one way or another. Thus, it does not matter by what political means that will is forged into law; what matters is how that will takes shape in society itself. The supremacy of the people in a democracy is obvious, and the formal institutions ensuring the division of powers cannot prevent it: the people rules in each of them, as each has to reckon with its opinion. De Tocqueville regards all 'government called mixed' as a chimera, as every society in the end follows 'one principle of action' that 'dominates' all the others ${ }^{489}$.

In democracy, this principle is overt; the power of the people is ultimately the power of majority opinion; moreover, it is potentially its omnipotence, as there are no safeguards against it. If it has not (yet) come to that in America, it is not due to the laws, but thanks to the mores of that society, which come from the old countries, England and Scotland; nor have 'circumstances' conducive to it appeared. De Tocqueville asks dramatically:

When a man or a party suffers from an injustice in the United States, whom do you want him to address? Public opinion? that is what forms the majority; the legislative body? it represents the majority and obeys it blindly; the executive power? it is named by the majority and serves as its passive instrument; the public forces? the public forces are nothing other than the majority in arms; the jury? the jury is the majority vested with the right to pronounce decrees: in certain states, the judges themselves are elected by the

488 De Tocqueville is perhaps the only author who, without being a philosopher, was one of the architects of the idea of civil society; 'what de Tocqueville did was to refine the state-society dichotomy', and this refinement may be considered his special contribution to that idea; cf. Krishan Kumar, 'Civil Society: An Inquiry into the Usefulness of an Historical Term,' The British Journal of Sociology, Vol. 44 (1993), No. 3, p. 381.

489 Cf. de Tocqueville, Democracy, I, Part Two, Chapter Seven, p. 240. Despite its democratic elements, in the allegedly mixed English political system aristocracy remains the dominant class. 
majority. Therefore, however iniquitous or unreasonable is the measure that strikes you, you must submit to it ${ }^{490}$.

Thus, the people of the United States, and more precisely its majority, governs its country like God Himself: it makes laws, directly or through its delegates, and is able to enforce them ${ }^{491}$. It is in this that its sovereignty expresses itself; political institutions are merely its executive arm. For this reason, de Tocqueville claims, this power is visible everywhere, and even if it is not, it will let itself be known whenever someone wants to hide away from it. The first to succumb to it, riding on the wave of the democratisation following the revolution, were potential aristocrats, i.e. the affluent classes; they did not even attempt to fight it, but ensured its amiability towards themselves and thus survived the eruption of the spirit of equality.

However, it is easier to see the sovereignty of the people in the public life of particular states, resembling small polities, than in the institutions of the Union itself $f^{492}$. De Tocqueville reminds his readers that the state under discussion is not only a republic, but also a federation, even if political power has been strongly centralised in it by virtue of the constitution ${ }^{493}$. Thus, looking at America from the perspective of the sovereignty of the people, he sees a country of local governments, provincial and township ones. He notes a characteristic relationship between the state and the federal authorities: contrary to the intentions of the architects of the constitution, federal government is weak and needs cooperation from state authorities. For this reason, it does not attempt to impose its standpoint, but seeks to win support for it, and when it encounters opposition, as a rule it gives up. De Tocqueville even gets the impression that the state governments appear in these disputes 'armed with the strength of the whole nation', while the federal Congress behaves like one of the many states ${ }^{494}$ (visiting America a few decades later, after the Civil War, he would probably have formed a different opinion on the matter).

Elections to representative bodies are special moments, in which the sovereign's opinion reveals itself most powerfully, the power of public opinion has the strongest impact on precisely these bodies. In fact, de Tocqueville claims, it also rules

490 De Tocqueville, Democracy, I, Part Two, Chapter 7, p. 241. In a footnote, de Tocqueville illustrates his fears with examples from the short history of the American republic.

491 Cf. de Tocqueville, Democracy, I, Part One, Chapter 4, p. 53-55.

492 Cf. de Tocqueville, Democracy, I, Part One, Chapter 4, p. 55.

493 Cf. de Tocqueville, Democracy, I, Part One, Chapter 8, p. 107-108.

494 Cf. de Tocqueville, Democracy, I, Part Two, Chapter 10, p. 353. 
in France, only there it manifests itself in revolutions rather than in lawmaking ${ }^{495}$. As compared to France, the power of opinion in America is therefore highly institutionalised, but contrary to Rousseau's fears, its institutionalisation through representation does not mean that the people hands it over to its representatives.

De Tocqueville does not enter into a polemic with the author of the Social Contract, but only invokes the characteristic image of the House of Representatives and the so-called ordinary people sitting in it: village attorneys and merchants, and even representatives of the lower classes. Such a composition of the lower house is supposedly a result of the direct election of its members; the 'natural instincts of democracy' make the people keep distinguished men away from power. This is not the case with the Senate, which, while also the product of universal suffrage, is elected indirectly, and in which the seats are taken by 'eloquent attorneys, distinguished generals, skillful magistrates, or well-known statesmen'. In elections to the Senate, it suffices that the popular will pass through this chosen assembly for it to be worked over in some way, and it comes out reclothed in more noble and more beautiful forms ${ }^{3496}$.

Nevertheless, it is still the popular will; it is out of the question for the individuals thus elected not to be subject to public opinion or not to actually represent the ruling majority of society. Even so, de Tocqueville makes a meaningful observation:

but they represent only the elevated thoughts that are current in the midst of it, the generous instincts that animate it, and not the small passions that often agitate it and the vices that dishonour it ${ }^{497}$.

Therefore, in order 'not to be miserably lost on the shoals of democracy', American democracy will have to increase the number of indirect elections, because it is the only way to prevent one social stratum from being dominated by the other. For universal suffrage places power in the hands of the poor, whose representatives will always act in their interest and be influenced by their passions ${ }^{498}$. De Tocqueville is by no means an absolute critic of this principle: democracy by its very nature promotes the welfare of the greatest number of people ${ }^{499}$; however, by means of indirect elections, it can do this in a more 'enlightened' way.

495 Cf. de Tocqueville, Democracy, I, Part Two, Chapter 7, p. 236.

496 De Tocqueville, Democracy, I, Part Two, Chapter 5, p. 192.

497 De Tocqueville, Democracy, I, Part Two, Chapter 5, p. 192.

498 Cf. de Tocqueville, Democracy, I, Part Two, Chapter 5, p. 202.

499 Cf. de Tocqueville, Democracy, I, Part Two, Chapter 6, p. 224. 
De Tocqueville, which may seem surprising, does not pay much attention to political parties themselves; the reason may be that at that time they were indeed still very fluid. Actually, he does not distinguish them from political associations in general. He is not in the least interested in how they win voters or mobilise them while in power or in opposition.

Likewise, it is perhaps no accident that the problem of the relationship between the representative and the represented appears in the Democracy only in the chapter on parliamentary eloquence. It is precisely the rhetoric of representative bodies that demonstrates how much the deputies depend on their voters. In a democracy, de Tocqueville emphasises, representatives never have permanent control over the minds of the voters; as they owe their positions to them, and not to party organisations, they have to make themselves credible before them at the forum of that assembly. This is the purpose served by fiery speeches; they are meant to attract attention to the speaker, who appears before the government in the role of a tribune of the people, more than to the cause itself. Standing on a rostrum, he speaks on behalf of all citizens, but also on behalf of each one separately, as

they are not even far from considering him as the proxy of each of those who elected him, and they flatter themselves that he will use no less ardour to put forward their particular interests than the country's $s^{500}$.

Everyone knows that in parliamentary rhetoric there are private interests hidden behind the public interest, but Americans are not outraged by this, because they expect political institutions to serve both kinds of interests; incidentally, they fail to distinguish precisely between the two.

The deputies' activities in representative bodies do not differ significantly from what citizens do directly in townships and counties. In getting involved on behalf of their community, they do not feel they are sacrificing their private interests, while in acting for their own good, they do not believe they are doing anything against the common interest. For the local communities, de Tocqueville claims, are small enough (townships have two to three thousand inhabitants) for their citizens to have a natural sense of common interest. Ever since their colonial beginnings, the New England townships have ruled themselves democratically and decided the matters falling within their exclusive competence at general assemblies held on the village green ${ }^{501}$. De Tocqueville deems these town meetings to be the essence of local democracy; they have taught Americans to

500 De Tocqueville, Democracy, II, Part One, Chapter 21, p. 473-475.

501 De Tocqueville notes that the further one goes from New England, the less active public life is in the township and the more active it is in the county; township meetings 
be responsible for their own country, taking care first and foremost of their local community: the state of the roads, the fate of the poor and, in particular, education. It was in this institution that the genius of the pioneers manifested itself; even though they were 'sectarian' on religious issues, they proved themselves to be great innovators on political matters.

While de Tocqueville recognises the great contribution made by the first generations of settlers to the building of a democratic America, he also emphasises that they merely made use of a free man's natural propensities that are in a way born of themselves; the state can only either strengthen or suppress them.

It is nonetheless in the township that the force of free peoples resides. The institutions of a township are to freedom what primary schools are to science; they put it within reach of the people; they make them taste its peaceful employ and habituate them to making use of it. Without the institutions of a township a nation can give itself a free government, but it does not have the spirit of freedom. Fleeting passions, the interests of a moment, the chance of circumstances can give it the external forms of independence; but despotism suppressed in the interior of the social body reappears sooner or later on the surface ${ }^{502}$.

Townships are small enough for the citizens to be able to look after them as they look after their property, and at the same time big enough that one can learn in them how to administrate well, mainly thanks to the institution of selectmen, officers elected by the town meeting to supervise the implementation of the general assembly's resolutions. The township described by de Tocqueville has nineteen basic functions, and each citizen is obliged to accept one. The selectmen's term of office is one year, and they are compensated for their services in proportion to their performance. The administration of bigger territorial units is obliged to implement the directives of the state and federal authorities; nevertheless, as these are local offices, citizens do not feel these policies are imposed from above or against their interests.

in new territories are less frequent, and they hand over most affairs to elected officials. De Tocqueville, Democracy, II, Part One, Chapter 5, p. 76.

502 De Tocqueville, Democracy, I, Part One, Chapter 5, p. 57-58. Robert T. Jr. Gannett writes on how de Tocqueville's interest in townships developed, beginning with mediaeval and Renaissance city communes, recalling, following François Furet (François Furet, 'The Intellectual Origins of Tocqueville's Thought', Tocqueville's Review, No. 7 [1985/86]), that he benefited considerably from a work of his political rival, François Guizot; cf. Robert T. Jr. Gannett, 'Bowling Ninepins in Tocqueville's Townships,' American Political Science Review, Vol. 97 (2003), No. 1, p. 1-2, 9. 
For de Toqueville believes that the American constitution has radically separated governmental and administrative institutions, even overstepping the limits of 'sound reason" ${ }^{503}$. The author of the Democracy believes this to be a proof of the genius of the founding fathers, a political factor no less important for forming responsible citizens than the institution of the jury. Even though no nation can exist without a strongly centralised government, administrative centralisation deprives it of its freedom, incapacitates it and reduces it to the role of a client vis-ŕ-vis the state.

Thus, the administrative authorities in America, claims de Tocqueville, do not excite the same sentiments as they do in France - envy and hatred - because local authority implementing official policies is placed at the side of those whom it administers, and in some way represents them ${ }^{504}$. Unlike in centralised France, this kind of 'representation' does not destroy public activity, because the fact that administration has taken up a certain matter does not allow citizens to consider it settled, if only because of its limited resources ${ }^{505}$. Generally, de Tocqueville observes in this context, American citizens do not believe it advisable to leave any matter concerning their community exclusively to the state to deal with. Thus while in France the power of administration is proportionate to the citizens' powerlessness, in America it is precisely the other way round.

Since the action of individual forces is joined to the action of social forces, they often succeed in doing what the most concentrated and most energetic administration would be in no condition to execute ${ }^{506}$.

Thus, local government and administrative decentralisation prepare Americans for engaging in public activities on a wider scale, and the imperfections of the executive power apparatus have the beneficial effect of leaving the necessary space, neither private nor administered by the state, for such activities. In this field, various associations appear going in their role far beyond corrective measures concerning governmental bodies and compensating for their imperfection.

As is customary for him, de Tocqueville does not provide even the most general definition of those, and also counts among them, under the description of

503 Cf. de Tocqueville, Democracy, I, Part One, Chapter 5, p. 85. That is why de Tocqueville, Kraynak argues, would sometimes even want, paradoxically, to see the majority wield more power; cf. Robert P. Kraynak, 'Tocqueville's Constitutionalism, The American Political Science Review, Vol. 81 (1987), No. 4, p. 1193.

504 De Tocqueville, Democracy, I, Part One, Chapter 5, p. 90.

505 De Tocqueville, Democracy, I, Part Two, Chapter 4, p. 180-181.

506 De Tocqueville, Democracy, I, Part One, Chapter 5, p. 90. 
'the permanent associations created by law', administrative units: townships, cities and counties; in this broad sense, each civic activity on a local scale takes place in associations. It is not these associations, however, that determine the special character of democracy; those founded by citizens themselves are more important here $\mathrm{e}^{507}$, as they express the Americans' belief that one can depend solely on oneself. For American citizens set up associations on any matter that needs collective action without waiting for government bodies to address it. Some of these issues have a distinctly political character, while others do not, and de Tocqueville accordingly divides the associations into political and social (non-political) ones ${ }^{508}$. The freedom to found associations of both kinds is as obvious to democracy as freedom of speech. In fact, the author of the Democracy regards them as almost identical; for it is to ideas, and not to interests, even if in democracy one transitions smoothly into the other, that he attributes the ability to mobilise people for collective action.

Political associations operate largely like the biggest of them, i.e. political parties. 'It is properly speaking the system of representation applied to a party', de Tocqueville observes ${ }^{509}$.

The logic of action of these organisations is as follows. A political association organises itself like a typical task group, only motivated by its members' sense of mission; they recognise a certain idea to be so important that they decide to disseminate it on their own. To this end, they not only present it in the press, but also propagate it at various meetings with an ardour that cannot be expected from the written word. Eventually, having won a major group of organised supporters/ fellow believers in the country, they decide to have that idea legally sanctioned, and to that end their representatives make an attempt to influence the legislative

507 That is why, de Tocqueville's conception of civil society is the closest to the Hegelian one, even though, as will be discussed below, his view on the relationship between civil society and the state is completely different from that of the German philosopher; for more on the subject, see Dana Villa, 'Tocqueville and Civil Society', in: The Cambridge Companion to Tocqueville, ed. Cheryl B. Welch (Cambridge: Cambridge University Press, 2007), p. 222-223.

508 In this connection, interpretations of de Tocqueville's views stress the decisive role of either the former or the latter in preventing the tyranny of the majority. Despite being in favour of political associations, Dana Villa nevertheless argues that a distinction between local and central political organisations is much more important to de Tocqueville; cf. Dana Villa, Public Freedom (Princeton-Oxford: Princeton University Press, 2008), p. 41-46.

509 De Tocqueville, Democracy, I, Part Two, Chapter 4, p. 181. 
body. Such an association is already, as de Tocqueville puts it, 'almost a separate nation inside the nation ${ }^{310}$; even if it does not have legislative powers, it makes use of the right to criticise the existing laws and propose draft legislation.

In that sense, it is actually competition for representative government enjoying the legislative monopoly. For a party with such aspirations, claims de Tocqueville, takes as much control of minds as it influences them; it does not just offer advice on legislation, it outrightly dictates it. That is why, both the government of a democratic state and the author of the Democracy himself are not enthusiastic about this function of associations.

One cannot conceal from oneself that unlimited freedom of association in political matters is, of all freedoms, the last that a people can tolerate. If it does not make it fall into anarchy, it makes it so to speak touch it at each instant ${ }^{511}$.

However, the author mitigates this unqualified declaration in the very next sentence: in a country in which one can pursue such activity openly, there are rebels, admittedly, but no conspirators. Civic activity of this kind poses a real threat only to a society that is not used to making use of its freedom, even if it, too, must limit it to ensure its survival ${ }^{512}$. Though it is rather unusual for de Tocqueville to see majority rule as a barrier to the negative consequences of the existence of free institutions, he must admit that, fortunately, political associations have to submit themselves to the test of general elections, which mitigates their radicalism ${ }^{513}$.

Characteristically, de Tocqueville does not put forward such reservations against minority associations, and not only because they are too weak to undermine the social order. He does not quote them in his work, but he certainly regarded many of the ideas promoted by them as no less dangerous and subversive. Unlike John Stuart Mill, he does not view them as morally and intellectually superior to widespread beliefs just because they are minority opinions. For de Tocqueville does not idealise minorities or their associations, but only the function they perform in the government system.

In serving to protect minorities against majority domination, they nolens volens serve the entire society, because they restrict its power, but only as long as they represent a minority. A minority group, de Tocqueville observes, organises itself for two reasons: in order to prove its power, expressing itself at least in

510 De Tocqueville, Democracy, I, Part Two, Chapter 4, p. 181.

511 De Tocqueville, Democracy, I, Part Two, Chapter 4, p. 184.

512 Cf. de Tocqueville, Democracy, I, Part Two, Chapter 4, p. 183-184; II, Part Two, Chapter 7, p. 503.

513 De Tocqueville, Democracy, I, Part Two, Chapter 4, p. 185. 
numbers, to the majority, and thus to weaken the majority's moral domination, but also in order to win that majority over to its ideas and, having attained that objective, to become a majority itself and impose those ideas on the general public in one way or another. Paradoxically, and fortunately for democratic society, there will always be minorities in it besides the majority, and as long as they are able to organise themselves, acting in their own interest, they will serve the common good.

In our time, freedom of association has become a necessary guarantee against the tyranny of the majority. In the United States, once a party has become dominant, all public power passes into its hands; its particular friends occupy all the posts and all organized forces are at its disposal. As the most distinguished men of the opposing party are unable to get over the barrier that separates them from power, they must surely be able to establish themselves outside it; the minority must oppose its moral force as a whole to the material power that oppresses it. It is, therefore, one danger that is opposed to another danger more to be feared ${ }^{514}$.

Americans seem to understand this, while European governments do not, mistakenly regarding every association as a threat to themselves and to the state as a whole ${ }^{515}$. But governments in the United States are elected by the same citizens who make up those associations, while in the vast majority of European countries government is still imposed upon the subjects.

From among the wealth of associations in the United States, those nonpolitical, social ones make up the vast majority. De Tocqueville sees in them that which is lacking in European countries: the republican spirit; they successfully complete ventures that the aristocracy takes upon itself in England, and the government in France. It happens so not even because Americans consider such a solution to be the most effective; to them, it simply seems to be the only possible one $^{516}$. And they are right, argues the author of the Democracy. In egalitarian societies people, isolating themselves from one another, remain powerless; however, once they unite in a joint effort, de Tocqueville writes emphatically, then they are indeed capable of anything ${ }^{517}$. Obviously, this is not easy if it requires

514 De Tocqueville, Democracy, I, Part Two, Chapter 4, p. 183. Even though de Tocqueville believes that religion plays an essential role in the preservation of the citizens' freedom, he fails to distinguish religious institutions themselves in this context; cf. Villa, 'Tocqueville,' p. 234.

515 Cf. De Tocqueville, Democracy, I, Part Two, Chapter 4, p. 185.

516 Cf. De Tocqueville, Democracy, II, Part Two, Chapter 4, p. 489-490.

517 De Tocqueville, Democracy, I, Part Two, Chapter 4, p. 181: 'There is nothing the human will despair of attaining by the free action of the collective power of individuals. 
cooperation of a large number of people, and de Tocqueville does not even polemicise with the view that the state would be more effective in many cases. However, the effectiveness of those activities is of secondary importance to him; paradoxically, it is the side-effects of those efforts, to be discussed below, that he considers important.

Attributing to ideas the role of a catalyst with respect to associations, de Tocqueville attaches particular importance to the press in this context. It is something much more than a source of information on the world, near and far. In order to act effectively, associations must be large enough, and this raises a problem of communication. Thus, in order to maintain contact between its members, and to forge a symbolic bond between them, every association needs its own newspaper, hence a close connection between the number of press titles and that of associations. However, the press does not serve associations exclusively as a means of communication between their members; to no lesser a degree, it shapes their opinions and attitudes. In a democratic society, newspapers influence public life the way aristocrats and clerics used to influence their local communities in earlier societies, i.e. by gathering people around them and acting as an authority to them. This is especially important to people in a democracy, individualists convinced of their own self-sufficiency, because, argues de Tocqueville, if they feel the desire and need to associate with the likes of themselves, they cannot find one another in the mass of individuals. The newspaper makes them aware of the closeness of other people; de Tocqueville attributes to it a role similar to contemporary social media. Even though only a few may speak out in it personally, the newspaper in a sense lends them its voice and speaks in their name.

A newspaper can only exist on condition that it reproduce a doctrine or a sentiment common to many men. A newspaper therefore always represents an association of which its habitual readers are the members [...]. [One] can say that it speaks to each of its readers in the name of all the others, and it carries them along the more easily as individuals are weaker ${ }^{518}$.

Thus, in an individualistic society newspapers ultimately form the same kind of bond as associations do. Even a periodical of a post stamp collectors' association plays a role here. Like in the stateless democracy discussed in the preceding chapter, it represents a certain social function, though within the limits of a topdown political and legal order.

Even though the two types of associations distinguished by de Tocqueville seem to serve quite different purposes and involve different individuals,

518 De Tocqueville, Democracy, II, Part Two, Chapter 6, p. 495. 
actually they are closely related. A society used to associating in mutual assistance institutions will be more inclined to associate to achieve political goals, and political associations promote and improve the activities of social associations. The citizens of a democracy, even though they mistakenly consider themselves to be self-sufficient, fortunately do not believe that they can do without cooperation with others, including in the political sphere. Thus, the first benefit resulting from the existence of associations that seek to gain power or at least influence the government is, paradoxically, precisely that they question the dogma of independence from other people without bringing into question the necessity of depending on oneself. Political associations shape the general habit of associating, not only for purposes of power, but also in very different contexts, for the sake of much less important issues.

For while social life does not abound in daily events that reveal the benefits to be drawn from living in a community, politics can mobilise citizens, as political goals affect them more strongly: the problem of customs duties within the Union will affect hundreds of thousands of citizens, but the construction of an interstate only thousands. People active in social associations often seek only their own interests; political associations can get them interested in the public good, and even teach them, voluntarily and deliberately, to subordinate their short-term individual interests to it.

This is not to say, however, that Americans only think of political associations in an idealistic way, without their characteristic pragmatism. Membership of social associations, such as merchants' unions, e.g., necessitates investing one's own capital and taking individual responsibility for failures. In political associations, rank-and-file members do not take any such risks. As in a democracy, failures of political associations do not result in repression against their members - members at worst waste their time (interestingly, de Tocqueville does not mention possible frustration and discouragement from acting), gaining in return organisational and teamwork skills. 'Political associations can therefore be considered great schools, free of charge, where all citizens come to learn the general theory of associations ${ }^{519}$.

Referring to his reservations concerning political associations voiced in Volume One of the Democracy, in Volume Two of his work de Tocqueville no longer has any doubts ${ }^{520}$ that associations, despite the limitations to which they

519 De Tocqueville, Democracy, II, Part Two, Chapter 7, p. 497.

520 Seymour Dresher writes on the differences between the first and second volumes of de Tocqueville's work, attributing them to the developments in Europe; cf. Seymour 
have to be subject even in a free society, are the foundation of its organisation. If the law did not allow the founding of political associations, non-political associations would probably be few, and their activities sluggish. For people and this is something that authoritarian government seems to fail to understand - do not want to get involved only in those undertakings that they are allowed to; from their own will and according to their interests they get involved in all those matters they deem to be worthwhile and beneficial.

Citizens of a democracy may be said to face an alternative: either they make the government responsible for the public order and, handing over part of their freedom to it, they do not want to participate in establishing it, or they want to establish that order themselves, take responsibility for it, and do not see any reasons why they should limit their freedom in the political sphere ${ }^{521}$. Social and political associations make up a single system, and even if the activities of political associations may slightly infringe upon the state's legal order, they contribute to a greater degree to strengthening the social order that exists independently of that legal order. 'It is therefore while enjoying a dangerous freedom that Americans learn the art of rendering the perils of freedom less great ${ }^{522}$, de Tocqueville argues. He sums up these considerations with a powerful statement:

If to save the life of a man one cuts off his arm, I understand it; but I do not want someone to assure me that he is going to show himself as adroit as if he were not one-armed ${ }^{523}$.

The author of the Democracy realises that the immediate results of the operation of associations will sometimes provoke enmity. And no wonder; they are obvious, while it takes a certain incisiveness in order to notice the benefits resulting from the side-effects of their activities. Incidentally, this is characteristic of democracy: the evil in it is obvious to the naked eye, while the good remains concealed. In an aristocratic society, it is the other way round: here each member of the not-so-numerous ruling class may individually earn himself a good reputation, winning the respect of his compatriots, both of his equals and of those dependent on him. The aristocracy took better or worse advantage of those opportunities and de Tocqueville is far from idealising it, all the more so as

Dresher, 'Tocqueville's Two Democracies,' Journal of the History of Ideas, Vol. 2 (1964), No. 2.

521 In a similar vein, Pierre Manent explains the basic difference de Tocqueville sees between the French and the American type of democracy, taking into consideration the role of the other above-mentioned institutions; cf. Manent, An Intellectual, p. 106.

522 De Tocqueville, Democracy, II, Part Two, Chapter 7, p. 499.

523 De Tocqueville, Democracy, II, Part Two, Chapter 7, p. 500. 
it served the cause of freedom involuntarily, in a sense; thanks to its status and its relative independence from the royal power it restricted the central government and, in a sense, 'shielded' the people against it. Thus, in this particular sense, it represented before the king all those subject to that power, even though this type of representation was not a relationship authorised or institutionalised in any way, and only sanctioned by custom.

In a democracy, by contrast, there are no bodies mediating between the central government and the equal citizens subject to it, who are therefore exposed to the rulers' absolute power. An individualised society, dispersing its forces in pursuit of individual goals, remains completely defenceless against centralised government. De Tocqueville does, admittedly, see the seeds of such a natural aristocracy in the circles of lawyers and entrepreneurs - he pins some hopes on the former and has some fears about the latter ${ }^{524}$ - but even if, by virtue of the legalism intrinsic to their professional ethos, they stabilise the political system to a certain extent, they will not change the character of society itself. This can only be achieved by associations of equal and free individuals; it will not tolerate any other mediating bodies.

If therefore an egalitarian society wants to enjoy freedom, it has to create a special kind of aristocracy for itself. This aristocracy, one of merit rather than blood, will be as much natural to the society as it will be artificial, since, valuing equality higher than freedom, the democratic man rejects the very idea of aristocracy. Actually, this idea needs to be smuggled into the minds of people enamoured of equality under a different name.

In this manner one would obtain several of the greatest political advantages of aristocracy without its injustices or dangers. A political, industrial, commercial, or even scientific and literary association is an enlightened and powerful citizen whom one can neither bend at will nor oppress in the dark and who, in defending its particular rights against the exigencies of power, saves common freedoms $\mathrm{s}^{525}$.

524 De Tocqueville argues: 'The body of lawyers forms the sole aristocratic element that can be mixed without effort into the natural elements of democracy and be combined in a happy and lasting manner with them' (De Tocqueville, Democracy, I, Part Two, Chapter 8, p. 254); on the other hand, however, 'the small aristocratic societies that certain industries form amid the immense democracy of our day contain, like the great aristocratic societies of former times, some very opulent men and a very miserable multitude' (II, Part Two, Chapter 20, p. 531-532). For more on what de Tocqueville thought about the industrialist class in the role of a new aristocracy, see Dresher, 'Tocqueville's Two Democracies', p. 207-209.

525 De Tocqueville, Democracy, II, Part Four, Chapter 7, p. 668. 
The first merit of associations is therefore to maintain the people in a state of relative independence of the government. Thus they prevent the 'mild' tyranny of a benevolent government, which might, with the citizens' consent, take all their affairs into its own hands one after another. For, jealously guarding their equality with respect to others, citizens of a democracy do not hesitate to strengthen the central government, continuing to add to its tasks but by the same token also to its competences. This is the lesson taught by French democracy. Associations, both the political ones and those that disavow politics, bring together, so to say, the dispersed forces of individuals; they pursue their own goals and oppose the government if they see a threat in its policies. With the help of associations, citizens can also defend their individual freedom, but only because they do it collectively; individually, they are powerless against the government. Thus de Tocqueville, not yet aware of the distinction between positive and negative, republican and liberal freedom, shows how much they depend on each other in egalitarian society.

The second side-effect of associations' activities is no less important. They mobilise people for joint action and reconstruct the bond weakened by individualism. Stripped of its charisma, political government is unable to forge that bond, and if it attempts to do so, de Tocqueville claims, it enters on the path leading towards tyranny, for citizens do not find it easy to distinguish a government's counsel from its orders. Paradoxically, the subjects of the same king in an aristocratic society are more closely related to one another than citizens in a democracy under the rule of a government elected by themselves. For the social bond is independent of government. By its very nature, a political government cannot maintain and renew 'the circulation of sentiments and ideas in a great people'; it only knows how to impose 'precise rules ${ }^{526}$; it is not able to create any warm community, so to say. A state of non-involved citizens remains a 'cold' and formal community, like its laws.

It is only associations, in which the public merges with the private and the individual with the collective, that warm it up with emotions shared by whole social groups. Associations and other free institutions allow people in a democracy to discover how dependent they are on one another; they 'recall to each citizen constantly and in a thousand ways that he lives in society ${ }^{327}$, not only in a state. While de Tocqueville does not invoke organicist ideas, actually they are not alien to him ${ }^{528}$; in any case, unlike classical liberals, he does not exacerbate

526 De Tocqueville, Democracy, II, Part Two, Chapter 5, p. 491-492.

527 De Tocqueville, Democracy, II, Part Two, Chapter 4, p. 488.

528 Cf. Manent, An Intellectual History, p. 106. 
the difference between the private and public spheres, as is the case in the minds of citizens in a viable democracy.

Similarly, though unaware of the so-called prisoner's dilemma, which in the following century would feature so prominently in social sciences, de Tocqueville demonstrates how Americans successfully avoid it. Involved in public activities, they seem not to notice the conflict between their individual and collective interests, as they associate their well-being with the fortunes of the Union as a whole. This is not a result of their naivety or simple-mindedness, however, but a peculiar 'theory': a long-known, unsophisticated doctrine of well-understood self-interest; it says that everyone has the right to be guided by one's own interest in one's life, as long as one behaves honestly, and honesty is equivalent to reciprocity here. 'Scratch my back and I'll scratch yours' is not a morally exalted principle, or one requiring exceptional sanctity, but instead one understandable to everyone, and an extremely useful one in an individualistic society because, as de Tocqueville puts it, if it does not lead directly to virtue through the will, it brings them [citizens - A.W.] near to it insensibly through habits ${ }^{529}$.

No less importantly, these are as much habits of the mind as of the heart; they resemble Aristotelian practices more than the utilitarian calculation of happiness. However, one must not look for the classical republican virtue in these habits; de Tocqueville views resurrecting that virtue in democratic society as unrealistic - a utopian ideal. In fact these habits are a form of egoism, however refined and 'enlightened' this kind of egoism may be. This is the only kind of attitude towards the public good one can demand from the democratic man, as it is the only one not contrary to his social condition. Guided by those habits, an 'American knows how to sacrifice a part of his particular interests to save the rest'; a Frenchman, to whom a sense of owning one's state is alien, may even be capable of heroic sacrifices for his country, but he cannot be relied upon.

One must therefore expect that individual interest will become more than ever the principal if not the unique motive of men's actions; but it remains to know how each man will understand his individual interest ${ }^{530}$.

529 De Tocqueville, Democracy, II, Part Two, Chapter 8, p. 502.

530 De Tocqueville, Democracy, II, Part Two, Chapter 8, p. 503. In Zetterbaum's opinion, de Tocqueville's trust in self-interest locates him, despite his apparent concessions, within the same tradition of modern political thought of which Machiavelli and Hobbes are the founders; cf. Marvin Zetterbaum, 'Alexis de Tocqueville', in: History of Political Philosophy, ed. Strauss, Cropsey, p. 777. However, the matter seems to be more complex; while invoking well-defined self-interest does indeed correspond 
If the author of the Democracy is not overtaken by 'soft and idle terror', it is because his trip across America convinced him that that interest may be understood differently from the way it is understood in his home country ${ }^{531}$. There remains a question, however, that he does not attempt to answer: will the Old and New World nations, which are condemned to democracy anyway, follow the American or rather the French way? Will they have a choice at all?

In the context of the subject of this chapter, according to de Tocqueville the difference between America and France consists in the fact that in France the state destroys the vitality of society, while in America the active part of society, i.e. civil society, subordinates state institutions to itself $f^{532}$. If the people maintains its sovereignty, the role of the government and government institutions must diminish. The political sphere is not superior to the social sphere and is not even institutionally separated from it; such are the ultimate consequences of the doctrine of the sovereignty of the people which is fundamental to democracy. Its will is largely fulfilled by civil society institutions and it does not matter very much whether these are openly or only indirectly political associations, given that there is no specifically political domain. The difference between them basically consists in the fact that the former want to achieve their goals directly through government institutions, while the latter influence those institutions through public opinion. Both the former and the latter trigger civic activity, preventing citizens' alienation, which by its very nature underpins individualistic society.

For in democracy, unlike in aristocracy, alienation of citizens is something much more dangerous than alienation of government. De Tocqueville does not fear the latter at all; on the contrary, he considers the relationship between the rulers and the ruled to be even too strong. No democratic government can rule the people for any length of time against its will. But democracy, which he stresses most emphatically, is always a majority government; the will of the majority will

with the liberal aspect of de Tocqueville's theory, it does not explain his republican sympathies.

531 De Tocqueville, Democracy, Vol. Two, Part Four, Chapter 7, p. 673. Even so, Manent observes that de Tocqueville must have seen in America the fundamental threat inherent in democracy, i.e. the threat of depriving an individual of his intellectual independence; cf. Manent, An Intellectual, p. 110.

532 Melvin Richter points out that history plays a decisive role in de Tocqueville's analysis, and though his analysis broadly resembles Montesquieu's considerations on political systems, de Tocqueville, mindful of the historical newness of democratic society, must carry it out in different terms; cf. Melvin Richter, 'Comparative Political Analysis in Montesquieu and Tocqueville,' Comparative Politics, Vol. 1 (1969), No. 2. 
eventually be sanctioned by law, as it already dominates in the sphere of mores, sanctioned by the routine of social life. This means that all those who remain permanently in a minority, even if they do not experience any kind of repression besides benign exclusion, may never experience a sense that government in the state belongs to them as well. Consequently, associations are for them virtually the only possibility for representation of their group interest. Associations certainly do not offer them chances equal to those enjoyed by the majority; nonetheless, if any organisations can prevent the exclusion of minority groups from public life, these are best suited for that role.

Having before his eyes the social progress that had occurred in Europe over the centuries, J.S. Mill argued that minorities ultimately shape majority opinion; it is only that they do so in the long term. De Tocqueville does not believe in intellectual progress; he fears, rather, that a voice contrary to prevailing beliefs remains a voice calling out in the wilderness. This is how the tyranny of the majority manifests itself in the most benign way ${ }^{533}$, and if anything is able to prevent it, it is first and foremost associations of active minorities. Thus, representation through civil society institutions contributes to a greater representativeness of the entire political system, even though it does not offer any guarantees that the central government's political decisions will also take account of minority groups' interests.

Even though de Tocqueville appreciates the necessity of governmental centralisation, he is far from attributing the sovereign's competences to any single institution. Civil freedom is much better served by the solution worked out by Americans, i.e. distributing sovereignty among civil society institutions (one must bear in mind that he counts townships and political parties among associations $)^{534}$. De Tocqueville would see nothing but a perfect tyranny in the assembly of the Sovereign of the republic presented by Rousseau. However, paradoxically, even though there is not a word of criticism of the institution of representation in de Tocqueville's work, just like the author of the Social Contract he would be absolutely against it if that relationship meant relinquishing the citizens' will to elected representatives. For the raison dętre of representative

533 On the relationship between the tyranny of the majority and mild despotism, see Małgorzata Kowalska, 'Demokracja przeciw arystokracji', Przegląd Polityczny, No. 72 (2005).

534 For according to de Tocqueville, democratic revolution changes the character of political power; by introducing a distinction between government and the sovereign, it substantially reduces governmental power; cf. Kraynak, 'Tocqueville’s Constitutionalism,' p. 1187. 
institutions is not to hand over power to anyone, but to create it out of individual citizens' wills; essentially, this is creating particular wills, whose existence worries Rousseau so much.

It is the concept of poliarchy, forged by Robert Dahl, that seems to best express de Tocqueville's democratic ideal, even though, unlike in Dahl's case this term would not mean here an inevitable departure from the ideal of full democracy, a concession to historical circumstances. To de Tocqueville, poliarchy is not second best to democracy, because he would regard Dahl's ideal of democracy (a society in which everyone had exactly the same amount of power) not as a utopia but as a nightmare. Power distributed equally among citizens is nothing but their powerlessness vis-ŕ-vis the only major power in such a society, i.e. the central government.

Poliarchy might be pictured as bubbles on the smooth surface of the powerlessness of particular citizens. The central government of course constitutes the biggest bubble, but others are also visible and, most importantly, quite numerous. They represent the support for the ideas the society believes in and the diverse group interests reflected in government policies. Thus, poliarchy is equivalent to the division of power among political institutions and civil society; civil society attracts and draws together part of the citizens' power: that part which they have not relinquished to the government. An equally important, and to de Tocqueville an even more important matter is that from the perspective of the central government these bubble-associations are a kind of counter-government, without which it would evolve towards despotism ${ }^{535}$. This is what the actual division of power in a democracy consists in. If, however, a strong central government suits the nature of an egalitarian society and arises naturally within it, citizens have to organise the other bodies vested with power on their own, acting together.

535 This also reveals the paradox of the very idea of civil society that Michael Walzer writes about: 'Citizenship is one of many roles that members play, but the state itself is unlike all the other associations. It both frames civil society and occupies space within it. [...] A democratic state, which is continuous with the other associations, has at the same time a greater say about their quality and vitality. It serves, or it doesn't serve, the needs of the associational networks as these are worked out by men and women who are simultaneously members and citizens'. Michael Walzer, 'The Civil Society Argument', in: Dimensions of Radical Democracy. Pluralism, Citizenship, Community, ed. Chantal Mouffe (London: Verso, 1992), p. 8-9. 


\section{A diversified society and a diversity of representative government}

Mill, Cole and de Tocqueville still regard social diversity as a problem stemming from the idea of representation, rather than one concerning institutions of representation. For it is not at all obvious that it requires institutionalisation in the political system itself. None of them actually proposes that social diversity should be reflected in government institutions by means of formal institutions of representation. It is neither possible nor necessary for the social and political order to be founded on a permanent consensus of the ruled. As opposed to Rousseau, who follows Hobbes on this matter, each of the authors mentioned above could say that the state is not, and therefore need not be, the sole guarantor of that consensus.

In the system outlined by Mill, political institutions are to represent only that which all members of a diverse society have in common; everything that differentiates them should remain in the private sphere. That is why, Mill decidedly rejects the very idea of reflecting the patchwork of group interests - this 'motley representation ${ }^{536}$ ' - in the legislature; representative institutions are to represent only one interest, common to all. Even if Mill allows a symbolic representation of people who do not meet the property requirement, it is only in order to ensure legitimisation for the government on the part of citizens questioning the legitimacy of their exclusion. The representatives of that part of society which does not pay the property tax are neither representative of it, nor do they increase the representativeness of the representative body.

For in this political system representation is both power and a source of knowledge to the rulers, which is in the interest of society as a whole; thus, it characteristically reduces the importance of the people performing that function. The only thing that is required from representatives, if there is a need to require it at all, is for them to be guided by their own interest, as, by virtue of the representativeness of the ruling category (a social class), it will be the general interest. They have virtually no obligations to their voters: they are neither their mandataries nor their trustees. Actually, there is no social relationship at all between the representatives and the represented, just as there is no social relationship between the representatives themselves; they only matter as bearers of some individual traits, aggregated in a representative body. In this

536 That is why, Anthony Birch is wrong in comparing this kind of representation to a microcosm; cf. Birch, Representation, p. 55-56. 
simplification one can recognise, Hanna Pitkin notes, the treatment of society as multiplied individual ${ }^{537}$, which is characteristic of utilitarians, but also something more: representative institutions simply hand over power over society to common sense, incarnated in the middle class.

With a fundamental difference of opinion on what society is, who its representatives are, and what they should be responsible for, Mill's idea strongly resembles Edmund Burke's virtual representation discussed in the previous chapter. In both cases, the point is for representation en bloc to reflect the diverse whole; representation of the whole is to justify denying the right to representation of particular interests, as they are already included in that whole. For the right to representation does not belong to social groups, but to society as a whole; it is only in this sense that each member of society can demand that the government represent his interest to the degree to which it is included in the general interest. Obviously, it does not take much incisiveness to see defence of the interest of the possessing classes in Mill's argument, though he is undeniably consistent in legitimising the rule of those classes in ideological terms, concealing their interests.

The logic of Cole's functional representation is precisely the opposite. Representative bodies jointly make up a microcosm of society, for only as a whole can they fulfil their role. They represent people in various aspects of their social life, and more precisely in all those in which they are present through their membership in voluntary associations. This kind of social organisation best serves well-socialised individuals, connected by common interests, but it does not force those who remain on the margins of social life of their own free will, and pursue their own interests on their own, to do anything. Each individual is socialised, and by the same token represented, to a degree to which he believes it to benefit him. Thus, functional representation is as representative as those concerned want it to be.

Being neither trustees nor mandataries of association members, representatives of associations resemble experts, with the important difference that associations do not hire them but choose them from among the number of their members. Therefore, representatives do not absolutely surpass the represented in terms of competence; nor do they need a support team of technocrats, who are not subject to social accountability; all association members, pluralists assume, will have enough expertise concerning association activities to undertake an advisory role and, at the same time, a controlling role with respect to

537 Cf. Pitkin, The Concept, p. 202. 
their representatives. They neither bind them with their instructions nor allow them autonomy. This solution, however, even if it is to prevent a rule by party bureaucracy, must be extremely demanding of association members, as it does not allow them to content themselves with a periodical election of a representative. Since every individual has as many representatives as there are associations of which he is a member, he will spend his whole life following their activities. Thus, Laski's aforementioned invocation of the Aristotelian concept of active citizenship is fully justified here.

However, this active citizenship is not pursued in a sphere which could be described as political in the Aristotelian sense: associations and their representatives also deal with matters that should remain in the domestic sphere. Rejecting the obligation of representation by state institutions, British pluralists have no confidence in civil society institutions either, as they see them solely as group interest representation, incapable of creating a lasting and just social order. Fearing the state, and at the same time understanding that coercion cannot be completely eliminated from social life, they institutionalise voluntary associations and equip them with the competences of a state, each of them within the limits of its scope of activity ${ }^{538}$.

In the broadest sense of the concept of politics, defined as the art of building a collective order, their project of society without a state indeed has a political character, and politics itself becomes ubiquitous. Functional democracy is therefore a fulfilment of the Marxist utopia of a society which has absorbed the state; state power is identical with social power here. The institution of representation does not connect the social and the political worlds, for they are one and the same.

Unlike Mill and Cole, de Tocqueville does not design an ideal political system, but the American democracy he describes offers a model solution to the problem of accommodating social diversity by means of representative institutions. While Mill's model of representative government clearly separates the social and political spheres, and Cole's model makes them overlap, in the case described by de Tocqueville the border between them is fluid. Actually, one can hardly speak of

538 Contrary to what de Tocqueville argues, these authors would rather agree with Gáspar Miklós Tamás, who says that due to the impermanence of associations and unlimited voluntarism, the idea of civil society is anarchistic relative to the legal and political system of the state; cf. Gáspar Miklós Tamás, 'A Disquisition on Civil Society', Social Research, Vol. 61 (1994), No. 2, p. 218. 
a border here, but rather of a whole sphere with blurred limits: a space of public collective action.

According to de Tocqueville, it is there that a democratic order ultimately emerges. This does not happen spontaneously, with minor involvement of the state, as Bentham and Mill assumed; nor is it produced by a tight-knit network of formal institutions, as assumed by British pluralists; this order is created by citizens themselves in more or less formalised institutions serving as much general social as group purposes. Political government, at the township, state and federal levels, remains permanently under the influence of such bodies in that kind of state, and that is why the United States is a republic not only in the legal, but also in the social sense. De Tocqueville's considerations show what kind of republic a democratic society may and may not be. A contemporary democracy becomes a res publica or 'public matter' only because its citizens recognise their own private interests in it. For 'a public matter' does not mean here 'a matter concerning all', but 'a matter shared by all,' which in an individualistic society always signifies 'shared by the majority'.

The institution of representation plays a major role in the process of making the state a public or shared matter. People in a democracy basically elect the likes of themselves as their representatives, and these representatives, either under pressure from their voters or independently of them, will act in their interest, more or less sincerely believing that they do so in the general interest. De Tocqueville does not expose that kind of 'bad faith', as he does not oppose to it any concept of a 'true' common interest; in democracy the general interest is ultimately what the majority deems it to be. Its representatives act for the common good in a thousand ways and in a thousand places, and the result is that an average American, de Tocqueville argues, has a fully justified sense that the state actually belongs to him. Citizens who, because they belong to minorities, do not share that sense, need representative institutions all the more in order to protect their vital interests against the majority's absolute power; an association not only gathers their dispersed power, but also multiplies it by giving it a public presence.

Thus, civil society fully reveals the paradox of representation of social diversity, because, thanks to civil society institutions, civil activity is transformed into additional political influence. It is a domain of freedom, not equality; individuals formally equal before the law, in fact become unequal here. The existence of such a sphere is fundamentally contrary to the idea of Rousseau's republic; nor is there a place for it in a utilitarian democracy, which leaves all non-political things in the private sphere, or in a functional democracy, which confines all civic activity within its institutions. For activities in civil society bring results that Mill's and Cole's institutions of representation were meant to eliminate: they distort a 
reproduction by the political system both of what is common to members of society and of what differentiates them. Thus, the paradox of representation of a diverse society consists in the fact that representation, through civil society institutions, infringes upon the representativeness of the system as a whole, which political representative institutions are meant to ensure ${ }^{539}$.

That is why, civil society will have its enthusiasts and detractors. Its advocates will see in it the activism of citizens not satisfied with only participating in elections and following politics via the media; they will see too these citizens' sensitivity to social wrongs and commitment both to their local community and to their homeland; and last but not least they will see minorities presenting their agenda at the public forum (briefly speaking, non-governmental organisations without which a democracy is not a republic). The detractors instead will see in it powerful corporations, pursuing their interests at the expense of the silent majority; outspoken lobbyists, hiding the fabulous profits of their employers behind the rhetoric of common good; and lastly volunteer work regarded as a holiday adventure or something to impress recruiters on a CV.

De Tocqueville is of course an enthusiast of civil society, but he would not deny all validity to the arguments put forward by its opponents. He would probably agree with the opinion that it is in civil society that the groundwork of class domination emerges, even though it is also within it (where else?) that he would notice the birth of emancipation movements. For if the strong may become even stronger by means of representation in civil society institutions, it is only in civil society that the empowerment of the weak may occur.

539 Suzanne Dovi, on the other hand, points to the difficulty with exacting accountability from informal representatives, as well as to the problem political theory has with that fact; cf. Dovi, The Good Representative, p. 60-68. 



\section{A contribution to the normative theory of representation}

\section{Representation as a concept connecting the normative and descriptive theories of democracy}

Numerous theorists of democracy regard the hiatus between the normative concepts of political philosophers and the empirical concepts of political scientists as a kind of scandal; appeals for integrating the two currents have been regularly repeated since the early $1970 \mathrm{~s}^{540}$. Characteristically, it is only the philosophers who feel a need to add some weight in the form of solid knowledge of how things really are to their purely axiological constructs, while empiricists, attached to their alleged impartiality, stop short of adding how things ought to be. The belief that an integrated theory is needed may lead to the emergence of outstanding works, such as Theory of Democracy Revisited by Giovanni Sartori (1987) or Michael Saward's study cited in the Introduction; but regrettably there are few examples of such works.

Even though I agree that a theory of this kind is needed, I believe that the appeals for a unification of both currents now resemble calls for a compromise between Platonic Socrates and the sophists, much hated by Plato. For it is not possible to unite into one coherent whole a theory imbued with values and one which rejects them in its very terms. For the neutral term 'political elite' from the empirical theory precludes the 'sovereignty of the people', expressed in one way or another, from the normative theory: there is no place for compromise between a rule by the people and a rule by the elites, just as there is no place for compromise between the logos and the amounts raised for an election campaign ${ }^{541}$. One can

540 One of the latest publications on the subject is an article by Ingrid van Biezen and Michael Saward. One of the reasons for that lack of discussion are definitions of the key terms, including of democracy, used by democratic theorists and empiricists; theorists harbour continued scepticism of large scale 'democracy' on the level of the modern nation-state, while scholars of political parties assume that democracy is a representative system; theorists focus on substance, empiricists on the procedures; cf. Ingrid van Biezen, Michael Saward, 'Democratic Theorists and Party Scholars: Why They Don't Talk to Each Other, and Why They Should, Perspectives on Politics, Vol. 6, No. 1 (March 2008), p. 26.

541 It is for this reason that I consider Ian Shapiro's idea of building a normative theory of democracy as rivalry between elites, which would result in minimalisation of domination, i.e. unlegitimised power, to be interesting though misguided; cf. Shapiro, The State, p. 146-151. 
hardly expect the philosophers and political scientists, however, to abandon the concepts that have served them well thus far within their own discourses, all the more so because the citizens of a democracy themselves speak both languages fluently: they demand their rights in the philosophers' normative language, but can speak about government itself like the most cynical political scientists.

That is precisely why I believe that the structure of a normative theory of democracy, free from contemporary academic grandiloquence, must be founded on a concept-idea from the second line of both theories, as it were, covering both the empirical and the normative aspects of political life ${ }^{542}$. A concept like that should describe and evaluate political realities, and at the same time be inclusive enough to make it possible to express diversified positions in both aspects. In fact, it has to be an essentially contested concept ${ }^{543}$. I therefore intentionally do not even attempt to define it in the conclusion of this book; a general definition of representation, ignoring the functions of representative government discussed above, would be of no value to a theory of that kind; on the other hand, a definition richer in content would actually itself be such a theory, to which the present work is to be a mere contribution.

The concept of representation, this work should have persuaded the reader, meets both of the above-mentioned conditions without any reservations. It reflects the formal relationship between the ruling and the ruled, and at the same time allows one to assess whether the former discharge their function well in the opinion of the latter. For it is as ambiguous as the term 'weather'; in some contexts, the 'weather' means 'good weather', just as 'to represent' means 'to represent well'; of someone who fails to discharge his function we will say that he 'misrepresents' or 'does not represent' the author at all, even if he has been granted a mandate $e^{544}$. The concept is complex enough that the question about the

542 This is also indirectly noted by Nadia Urbinati in the article mentioned in the Introduction: 'Thus, the theory of representation as advocacy entails a notion of citizenship that is egalitarian in principle but still takes power relations into account. Because its normative principle is political equality, it aims to give voice also to positions of subordination'; Urbinati, 'Representation as Advocacy', p. 778.

543 Cf. Walter B. Gallie, 'Essentially Contested Concepts,' Proceedings of the Aristotelian Society, New Series, Vol. LVI (1955-56); John Gray, 'On the Contestability of Social and Political Concepts,' Political Theory (1997), p. 3.

544 Ultimately, argues Andrew Rehfeld, whether somebody was indeed authorised to act as a representative of the author in a given situation is decided by a subjective opinion of the audience, before which the act of representation took place; cf. Rehfeld, 'Towards a General Theory of Political Representation, p. 15-18. 
very relation of representation - i.e., what it means that someone represents me may be made the axis of discourse as a whole, both the academic and the strictly political one. David Runciman and Mónica Brito Vieira even write,

we need to be careful not to assume that deciding what kind of representation best suits the state means avoiding any ambiguity in our answers; it may be that the ambiguity of representation is one of the things that enables states to function successfully $y^{545}$.

In fact, if critics of representative democracy are right and the crisis of that form of state is indeed a crisis of representation, then it is precisely that idea and institution that should be the subject of particular reflection, rather than a quick rejection. What such an approach requires, however, is going beyond the schematic explanations proper to the normative theories of democracy and adequate within their symbolic universes, but of no use whatsoever in exploring the actual power relations. Thus, to make a normative theory more realistic, one has to view the relations between the ruling and the ruled from a different perspective and see in the contemporary state not so much a democracy, but a representative system. Accordingly, while assessing its institutions, one should ask whether they give the citizens the power to influence the government, instead of complaining that they deprive them of the power promised to them by the idea of sovereignty.

The question is how we want to see the fit between democracy and representation. One approach is to decide on certain normative criteria for democracy and then to examine which forms of representation provide the best prospect of meeting these norms. An alternative is to see which model of representation best describes the workings of the state as it has evolved over time and then to ask whether and how this model might be democratized ${ }^{546}$.

Naturally, this does not mean questioning the democratic character of the contemporary state, but only a shift in its normative aspect. Western democracy has today, almost without exception, a liberal and representative character. Particular countries do not differ from one another as to the extent of political rights that all citizens enjoy; nor do they differ, practically, in the scope of protection of civil rights and individual liberties. What they do differ on, considerably, is the prevalent political culture, and the accountability of the rulers to the ruled is one of its dimensions. Even though formally each democratic government is representative by virtue of constitutional provisions, no constitution can guarantee to the citizens a sense that the politicians they have elected rule exclusively by their

545 Runciman, Brito Vieira, Representation, p. 124.

546 Runciman, Brito Vieira, Representation, p. 126. 
mandate and do not remind themselves of that relation only before an election. Nor does it mean, however, and this book was to serve as a reminder of this, that the politicians are meant to rule completely in accordance with the citizens' will, and only thus; in a representative system a situation like that is only possible in a symbolic sense.

Perhaps the most radical critics of representation are not wrong on the issue and the contemporary state indeed must change to remain democratic, but if a normative political theory is to have its part in this change, it has to undergo an intellectual revolution of Hobbesian proportions itself. A revolution of this kind even seems inevitable, considering how much the state has changed from the time when the process of its democratisation in representative institutions ended. The question of which ideals suit it better today (whether those of democratic government with a limited representation, or those of representative government with a limited democracy) remains an open question, but it goes far beyond the framework of this book.

\section{A realistic theory of representative government and 'another' theory of democracy by Joseph Schumpeter}

Paradoxically, present-day political philosophers questioning whether representative government has a democratic character follow in a sense the direction outlined by the first critic of this way of thinking about politics which they follow. Joseph Schumpeter's so-called realistic or empirical theory of democracy (he himself called it simply 'another' theory), expounded shortly before the Second World War - that is, at a time when parliamentary democracy was not yet, even in the Western world, an unchallenged political ideal - exposes at its starting point the myth that the power is exercised by the people. There is no state in the world where that is the case, Schumpeter claims; people's power does not mean anything more than consent to a rule by party elites.

Naturally, today this claim may be regarded as revealing the truth about Santa Claus. Incidentally, in Schumpeter's time, too, thanks to the popular books by Gustav Le Bon, and more or less academic publications by Vilfredo Pareto, Gaetano Mosca and Robert Michels, it was not particularly revealing. This truth is not all that cruel, considering that the less fortunate peoples are ruled by dictators by the consent of the military, and a fourth of the world population is now governed by a party oligarchy. For that reason, one can understand why, despite all else, the normative theory of politics attaches greater importance to the fact that it is the citizens who 'ultimately' elect politicians, even if it is 'ultimately' the politicians who rule the voters. 
In any case, a normative and at the same time realistic theory of representative government should begin with an act of iconoclasm: ignore constitutional provisions which stipulate that power in the state belongs to the Nation that exercises it directly or through its representatives. Present-day democracy is ruled by politicians who represent the ruled better or worse, while the citizens variously influence the government, so that it cannot be arbitrary in any way. To political scientists a statement like this sounds trivial, even though actually it is not, as they might believe, only a simple statement of facts; it is a hidden normative judgement, presuming that one is inclined to admit that a government which rules in agreement with public opinion is better than one which does not take it into consideration. If this statement, too, smacks of the trivial today, it is only because it will be questioned exclusively by those who in general reject the representative character of government or insist that it represents on Earth, over the heads of the ruled and instead of them, some higher value: God, Order or historical Progress. Even though in this iconoclasm (yet to be explained below) the normative theory of representation may not blindly follow Schumpeter's theory, neither can it afford to ignore it, for in fact it presents a vision of democracy without representation and is silent on all those of its functions which have been discussed in the present work.

Even though to Schumpeter, too, the criticism of what he calls the classical theory of democracy is more than a mere introduction to the presentation of his own idea, it is neither particularly revealing, nor very interesting, and, most importantly, it is based on a surprising misunderstanding. For its author gave the status of a theory to the rhetoric of young democracies of his day, caught in a bitter ideological struggle, and thus not by accident overusing Rousseau's revolutionary parlance. To use Plato's expression, one might say that in the best case this was an 'opinion of the many', which had been given relative coherence by demagogues. Actually, it had been shaped by several theories, in places completely inconsistent with one another; in this respect, each 'general' theory of democracy is still, incidentally, a real bricolage, as one can find for oneself by consulting any encyclopaedia of social and political sciences. Meanwhile, Schumpeter attributed to the authors of that 'theory' almost exactly what Niccolo Machiavelli had accused Greek philosophers of four hundred years earlier: naivety, or in any case wishful thinking, in politics.

The essence of Schumpeter's criticism is the concept of the common good, and the institution of representation is subordinated to it in this context as a procedure for 'discovering' that good. Misinterpreting Rousseau's idea by attributing to him the substantial concept of the common good (actually the general will establishes rather than discovers it), Schumpeter combines into a single 
procedure the mutually exclusive general will and utilitarian aggregation; incidentally, present-day aggregation theorists make the same error ${ }^{547}$, possibly under Schumpeter's influence. Therefore, Schumpeter erroneously attributes features of rationality to the general will and makes vigorous claims that in their choices people are not guided by reason - a subject on which Rousseau himself maintained a meaningful silence, only stressing the fact that individuals make their own choices. In a long argument, invoking Le Bon's psychology of the mob and Pareto's sociology, Schumpeter also challenges the premise that individuals are aware of their interests and may recognise them despite ideological pressure from propaganda. Thus in fact he challenges all the premises of a non-existent theory of democracy, which were contentious rather than obvious issues to the authors discussed in this book.

Several of Schumpeter's criticisms refer directly to the institution of representation, even though, characteristically, in his reconstruction of an alleged classical theory of democracy he does not even distinguish between direct and representative democracy; looking at democracy from the perspective of its fundamental objective, that is, achieving the common good, he does not see any difference between direct and indirect rule by the people. First, he makes brief assurances that there is no question of such representation whatsoever - a rule by a parliament elected by a popular vote is in no sense a rule by the people - only to argue subsequently at length that such a rule does not lead to the common good of the people at all.

One may only speak of representation in a democracy in an ideological sense, Schumpeter argues; in this respect, the parliament does not differ in any way from the mediaeval estate assembly. The idea of representation serves to preserve the myth that direct democracy leads to sovereignty for the people, while the institution of representation is completely subordinated to one aim: the election of the government, of which Schumpeter writes disdainfully:

This committee or body of delegates, as we have seen, will not represent the people in a legal sense but it will do so in a less technical one - it will voice, reflect or represent the will of the electorate... [A]mong these smaller committees there will be a general-purpose committee, mainly for dealing with current administration, called cabinet or government, possibly with a general secretary or scapegoat at its head, a so-called prime minister ${ }^{548}$.

547 Cf. Shapiro, The State, p. 10.

548 Joseph Schumpeter, Capitalism, Socialism and Democracy (London and New York: Routledge, 2003), p. 251. 
Schumpeter's criticism does not ultimately go beyond the well-known Platonic topoi, merely extending them to cover representative democracy; it is aimed against the institution of representation itself because this has been subordinated to the principles of democracy. Nor does Schumpeter question the procedure of deliberation associated with it, but only that kind of deliberation in which the deliberative body is elected by all citizens. He does not go as far as Le Bon, who attributes the mob logic to each assembly, even to a court. He argues similarly in the case of the aggregation of the common good; only democratisation, i.e. extending the community, makes it impossible to derive it from individual interests in the representative body. Thus, unlike the present-day critics of representative democracy, Schumpeter challenges its democratic rather than its representative character, but also, like them, he reduces the institution of representation to that single function it is unable to perform: expressing the will of the people, i.e. transferring it to the representative body. Concerning the other functions of that institution, Schumpeter's theory has virtually nothing to say.

Moreover, it seems to leave no place for representation in political life, at least for a kind of representation that would be a way of rationalising the political process. The problem, however, consists in the fact that this theory demands too much from representation. Developing an analogy between the economy and politics, Schumpeter, a positivist and methodological nominalist, unacceptably simplifies the image of the scene in which political life takes place. However, he rightly reverses the direction of the political process. The concepts of representation invoked in this book started that process 'from the bottom up', from the represented interests or public opinion, while his theory starts 'from the top down', from politicians-representatives themselves. As entrepreneurs seek purchasers for their commodities, they also seek voters to whom to propose their services in parliament. It is not the represented who elect from among themselves their representatives to parliament, but politicians themselves, which always means that party organisations, aspiring to power, announce their readiness to represent various interests and stand before the voters with their programme-offer ${ }^{549}$.

Politicians, incidentally just the way merchants do, do not address their offer to individuals, but to entire categories of the population, sometimes perfectly

549 Schumpeter may thus be regarded as, to say the least, a forerunner of the present-day 'constructivist turn' initiated by an article by Michael Saward 'The Representative Claim' from 2006, followed by his book of the same title. An Economic Theory of Democracy by Anthony Downs (New York: Harper and Row Publishers, 1957) is also based on the assumption that it is politicians who make a representative claim. 
organised ones (such as trade unions) who make decisions to support this and not that candidate collectively, not individually. Between the election programme of politicians and a vote cast into the ballot box by voters, there is a place for something more than mere party propaganda. In fact it is between the two that civil society is located, with its diversified interests and opinions that need to be represented ${ }^{550}$, and a realistic ideal of representative government must take this fact into account. It will not be realistic at all, however, unless we assume, following Schumpeter, that it is politicians who are the most active force in the political process and that it is they who initiate it ${ }^{551}$.

We therefore need to see politicians, and more precisely speaking political parties, as potential representatives. Even in a multi-party, relatively open political system, social groups and organisations elect for themselves a representation mainly from among the parties acting within it, in the best case placing their representatives on the lists. Contrary to what Schumpeter claims, a relationship of this kind does fit within the logic of representation, however, provided that we assume that a contract of representation under civil law need not be its model. Actually, given the peculiar character of political relations and the nature of election programmes and 'promises', that kind of model would be completely useless for formulating a realistic ideal of representative government.

For, firstly, a government of that kind need not have its source in formal authorisation, a contract between the represented and the representative, and in politics it never does have. For the very act of voting is not an act of formal authorisation. Moreover, in non-democratic or newly democratic states, even usurpation may lie at the beginning of government, a usurpation that only after some time becomes expressly or tacitly sanctioned by the represented ${ }^{552}$. Moreover, an initial legitimisation of political government may also be effected by an external authority, which occurs as a rule in the case of military coups. The new ruling group rightly seeks recognition abroad first, for it is indeed easier to

550 That is why, the critics of the 'constructivist turn' counter it with the 'citizen standpoint', in which politicians' activity is secondary to initiatives by organised groups; cf. Lisa Disch, 'The "Constructivist Turn" in Democratic Representation: A Normative Dead-End?', Constellations, Vol. 22, No. 4 (2015), p. 492.

551 For the orthodox democratic theorists, as illustrated, e.g. by their reaction to the constructivist turn, it is difficult to accept that a theorist does not assess the democratic character of the offer of representation itself (e.g., one of limiting civil liberties), but leaves this to the voters; cf. Disch 'The "Constructivist Turn,"' p. 488.

552 Such cases are taken account of in Andrew Rehfeld's general theory of representation outlined above; cf. Andrew Rehfeld, 'Towards a General Theory' 
get it from other governments than from their own fellow citizens, particularly in a world divided into ideological camps.

Even though in a democratic state the only procedure for legitimising representative government is an election (an election held, moreover, in a manner that does not provoke protests from the opposition), this should be considered an exception, specific to the Western-type democracy. Consent, from the Second Treatise of Government by John Locke, will undoubtedly be a more useful formula for assessing many non-European governments, and at the same time less demanding and closer to the essence of representative government. Representative government need not be elected by the ruled; it may not, however, rule against their will. Thus, legitimisation by means of consent allows us to speak sensibly of non-democratic representation, which is not antidemocratic at the same time.

Secondly, it follows from the nature of politics that relations between a representative and the represented may not be formalised, and mutual obligations exacted in the same degree as in the domain of the law or the economy. Laments over politicians' failure to keep election promises or their general lack of loyalty to their voters will not do much good here. In reality, citizens may not extort it out of their representatives; but neither, equally crucially, and which escapes the attention of critics of institutions of representation, may politicians demand loyalty from the citizens they represent. Loyalty characterises only the hard electorate, who always vote for the party, not for its election programme. The lack of loyalty of politicians vis-à-vis their voters, which must necessarily be distinguished from a lack of accountability of the government to the ruled, is almost a blessing, however, as argued by Albert Hirschman in his classic work Exit, Voice, and Loyalty. For an absolute loyalty of the electorate to any given party would lead to its impunity, while absolute loyalty of the party to the electorate would deprive it of any possible coalition power.

Thus, both loyalty and a lack thereof benefit both sides in politics; disloyalty towards some voters is usually caused by an attempt to win over new ones. Democratic rhetoric, treating the people as the sovereign, and the government as its arm, is characteristically asymmetrical on the issue; the citizens' disloyalty towards the party is called their right to choose, the party's disloyalty towards the citizens is betraying their interests. It is worth noting, incidentally, that the opposition in parliaments usually develops here a peculiar kind of schizophrenia, calling upon the ruling party to implement the programme which it denounced as the worst possible one during the election campaign.

Thirdly, even if Schumpeter were right and the sense of representation in a democracy would be reduced to the election of the head of government, which 
obviously is not, and has probably never been the case, it is this feature that importantly distinguishes the government that may be elected from the one that only needs to be accepted. Both may be ultimately legitimised (even ancient tyrannies in the archaic period enjoyed the support of most of the residents of the polis); nevertheless, appointing a government by means of an election, even a one-time election, gives the ruled a much more solid basis for withdrawing their consent to its rule than in the case when it is legitimised otherwise. In his Reflections on the Revolution in France, Edmund Burke must rise to the heights of his polemic talent, arguing that there is no relation like that.

In Lincoln's definition of democracy cited in the Introduction - government of the people, by the people, for the people - the expression 'from the people' no longer appears only because in America at that time, a century after the War of Independence, it was obvious. However, in the era preceding the secularisation of the state and political thought, even democratic power still came from God (vide Florence under Savonarola's rule) and those wielding it could (exceptionally) be removed from power exclusively under the authority of God's law. Schumpeter rightly observes that in democratic 'theory' the people replaced God in that role, but does not draw any conclusions from that fact. However, the people, just like God, may change its will and the possibility of that change is provided for in the political system itself.

Fourthly, on this point Schumpeter, and Rousseau before him, are indeed right: by means of representation the rulers become the ruled. Orders sanctioned by law now travel from the top down, rather than from the bottom up. A representative remains in a privileged position in relation to the represented. Even though he is elected, he is select. The election is the privilege of the represented, but it raises the representative's status even further: he becomes a public figure, with all the benefits, and all the inconveniences, involved. The ambivalence of his status, when potentially all power finds itself back in the citizens' hands, reveals itself only at the time of an election.

Invoking Schumpeter's analogy with the economy, one must not overlook the fact that the citizens are not choosing a commodity but a service. A politician as a representative is meant as much to express the will of the people he represents, as to further their interests, and in this function he is closer to an expert than to a delegate. An expert offers his services, but he demands to be paid for them; not only does an expert draw a remuneration from the client, he also has an advantage over him in that frequently matters of vital importance to the client rest in his hands. Naturally, all this happens in accordance with the wish of the client-author, even though the client's will is counterbalanced in this relation by the expertise and competences of the representative. 
Fifthly and finally, Schumpeter's conception gives politicians an almost exclusive right to organise the public order; while it does not say so explicitly, its message is clear on this point ${ }^{553}$ : politicians are responsible for what according to Aristotle falls on the shoulders of the whole community of citizens. Do they form this order ex nihilo only because they control the political agenda? In this case, too, the analogy with the market has its limitations. For politicians do not control the agenda in a way that allows them to shape it independently of the structure of public interests, just as entrepreneurs cannot fully control the demand.

For the economic commodities market is not fully elastic in this respect. The consumers spend a considerable part of their incomes on inelastic demand goods (food, clothing), and they bond themselves with producers (brands) by ties other than only economic rationality, including a kind of sentiment or fashion. So it is with the citizens; in established political systems, ritualist voters, who have always supported a given party, even though they are tempted by others with agendas more consistent with their interests, make up a numerous group of voters. In casting their ballots, they do not actually make a choice (let us ignore those who do not attend an election at all). A rivalry between party elites, claiming the right to represent the voters, always occurs within a broader public order including even those citizens whose interests are not represented in the political system or are represented 'vicariously' by politicians elected by other voters ${ }^{554}$.

\section{The paradoxes of the idea of representation, i.e. the classics' contribution to the contemporary normative theory of representative government}

Even though Schumpeter's theory of democracy, focused on the procedure of appointing the government, does not incline one to view the relation between the rulers and the ruled in terms of representation, neither does it preclude that approach, provided that we look at it in an equally revisionist way to how he looked at the government by the people promised by the classical 'theory' of democracy. That is why a normative, but at the same time realistic theory of representative government should, while preserving the central idea of Schumpeter's theory

553 Cf. Schumpeter, Capitalism, p. 289-295.

554 This corresponds to the 'surrogate representation' Jane Mansbridge writes about; cf. Mansbridge, 'Rethinking Representation,' p. 522-525. This form of representation, not unlike traditional representation, termed 'promissory' by Mansbridge, naturally also leaves politicians a choice as to which groups are worth advocating for in the parliamentary forum. 
(i.e. the initiation of the political process by the representatives), be founded, in spite of all, on that tradition of political thinking which Schumpeter himself rejects as idealistic. Incidentally, as regards most of the works quoted in this book, this opinion is off the point. The analyses presented in them are often closer to present-day political science than to political philosophy, even though their authors, not bound by the demands of positivist methodology, do not conceal the values, i.e. the normative objectives, which the institution of representation should serve; such objectives, as seen from the perspective of political sciences, are the functions of political power. These functions must be performed by any representative government; in a democracy, however, this entangles it in paradoxes, which were presented in the form of conclusions at the end of individual chapters. The theory under discussion must therefore address each of these paradoxes.

The paradox of the legitimisation of power reveals that the representatives, always exposed to the accusation of usurpation, need the represented in order to legitimise their power. No matter whether a relation of that kind was established formally, a representative is someone who in place of the represented fulfils his will, provided that this is recognised or legitimised by the proper audience, before which that relation occurs ${ }^{555}$. It was of course completely unnecessary for God to have someone to fulfil His will on Earth, given that He Himself is almighty, but it turns out to be necessary for legitimising the power of the monarch claiming to be His vicar. However, when the People or the Nation appears in God's place, before whom is the electorate represented by its elected representatives? Before the same people, naturally, only now spelled with a small letter. Thus, by virtue of the institution of representation, the ruling People becomes the ruled people;

555 The representative turn brought two concepts of an audience. To Michael Saward, an audience is the addressee of an offer of representation ('Representative claims can only work, or even exist, if audiences acknowledge them in some way, and are able to absorb, reject, or accept them, or otherwise engage them'; The Representative Claims, 2010, p. 48). In the opinion of Andrew Rehfeld, by contrast, an audience assesses the very act of representation ('Political representation, I argue, results from an audience's judgement that some individual, rather than some other, stands in for a group in order to perform a specific function. The audience uses a set of "rules of recognition" to judge whether a claimant is a representative in any particular case.'); cf. Rehfeld, 'Towards a General Theory'. The audience under discussion, therefore, corresponds to the one from Rehfeld's theory. I additionally emphasise that an audience authorises a relation of representation when there is no obvious representative, and even itself helps to constitute it or chooses it from among the usurpers making representative claims; cf. Waśkiewicz, 'Representation as Social Relation', p. 307-309. 
the idea of the citizens' rights only conceals this paradox. Accordingly, to represent someone in politics ultimately means to exercise power over them; this was already discovered by Rousseau, and that is why in his project of a republic he eliminated all institutions of representation. Radical critics of representative democracy follow Rousseau; they expose the role of institutions of representation, reducing it to sanctioning the people's obedience to the government.

The lack of an audience for present-day representative government is the cause of its greatest weakness, namely a deficit of accountability to the represented. The absence of a third party means here the lack of an authority which could, in place of the represented, force the representatives to discharge this function properly ${ }^{556}$. A contemporary member of parliament may fear that he will not find himself in the house in the next term of office, though not necessarily, for the memory of the voters is surprisingly fallible, but until the next election he enjoys virtual impunity ${ }^{557}$. The first task that a theory of representative government must set for itself will therefore be to find effective methods of increasing the rulers' accountability to the ruled, because this government legitimises itself precisely by the consent of the ruled to accountable rule $e^{558}$. The issue that theories of democratisation of democracy focus on is that it is not enough only to find ways of including citizens and preventing their alienation; power exercised

556 Rehfeld admittedly notes that in the peculiar case of democratic representation even the three parties to that relation are identical with one another, but he does not elaborate on that subject, not seeing it as any major problem; cf. Rehfled, 'Towards a General Theory,' p. 11.

557 Ruth Grant and Robert Keohane distinguish between two kinds of accountability: to the people who delegate the power and to the people whom government decisions concern (delegation vs. participation model). Both occur in democracies, but neither of them has a formal or legal character; cf. Ruth Grant, Ruth Keohe, 'Accountability and Abuses of Power in World Politics', The American Political Science Review, Vol. 99, No. 1 (Feb. 2005), p. 30-31. John Gastil extensively explains, using the US example, why elections cannot force politicians into accountability; cf. John Gastil, By Popular Demand. Revitalizing Representative Democracy through Deliberative Elections (Berkely - Los Angeles - London: University of California Press, 2000), p. 32-67.

558 It is therefore not an accident, as Pierre Rosanvallon claims, that the principle of transparency has replaced the principle of accountability to the people. 'Instead of seeking to achieve political objectives, people seek certain physical and moral qualities... Transparency, rather than truth or the general interest, has become the paramount virtue in an uncertain world'; Rosanvallon, Counter-Democracy, p. 258. 
even directly by the people need not necessarily mean a more accountable government ${ }^{559}$.

The paradox of sovereignty of representative government, formulated by Thomas Hobbes, and later, in relation to a democratic state, by Carl Schmitt, shows its Janus face. As it acts by the will of the ruled, the Nation represented by the government remains a nominal sovereign in the state. In a state of emergency, the government, or its representative, suspends this relationship, however, to become the sovereign; at times like that it only represents the individuals' will to survive, assuming that this requires the preservation of the state. Thus, representation ultimately ensures a sovereign rule over a sovereign nation. The constitution specifies who and in what kinds of situations may use this special attribute of sovereign power precisely as a representative of the whole commonwealth. The basic prerogative of representative government lies therefore, paradoxically, in the very fact that it has the right to use violence against its principals.

In this connection, it is up to a theory of political representative government to justify the coercion on the part of the government, obliged to act on behalf of the represented. This is not only about a situation typical of democratic government, in which members of a minority must agree with the will of a majority; they will do so with more or less conviction, bearing in mind that on another issue they will find themselves in a majority. What is needed is a justification of, and a precise definition of acceptable terms for, government action against the will of a prevailing majority of the people, expressed both in opinion polls and in street protests. In certain cases, this will be a question of providing arguments for imposing a state of emergency, but situations in which such justification is needed regularly arise in a less drastic form, e.g. when governments take drastic austerity measures. In such instances, they actually invoke their responsibility, though not to the ruled, but to the state as a whole - i.e., to the future generations, who cannot exact it in the next election. A theory of representative government must therefore address the problem of the arbitrariness of sovereign government, i.e. its exceeding its mandate, while at the same time preserving its

559 It is therefore not enough, either, as Suzanne Dovi puts it in a purely normative theory of representation, to create 'an ethics of democratic representation that articulates a framework that citizens can use in developing criteria for determining when political representatives have abused their authority as democratic representatives. Such an ethics needs to identify what it means to excel at representing in a democratic fashion - for in doing so it will be providing the needed framework for going about distinguishing good democratic representatives from bad ones'; Dovi, The Good Representative, p. 67. 
legitimacy. The theories of democratisation of democracy do not address it at all, granting the government almost a monopoly on redistribution of goods, but without mentioning coercion, as they equate coercion with violence and push it beyond the limits of the political ${ }^{560}$.

The paradox of limitation of power concerns a question much closer to the critics of representative democracy. Even though this limitation is institutionalised in the mechanism of division of power, the balance of social interests turns out to be the ultimate condition of the citizens' security, ensured thanks to the presence in representative bodies of an opposition capable of 'interfering', as Montesquieu put it, with the government. For if a 'majority faction' is formed within society, of which the architects of the first democratic state were already afraid, this mechanism will not function properly, as each of the formally independent powers will remain in the hands of that faction. It has taken Western societies almost a century to achieve a balance of interests; thanks to the institution of representation, it was transferred into the political system. Voters do not expect representatives of their group interests to maintain that balance, however, but to disturb it for their benefit. Urging the government to promote their group interests exclusively, they thus expect, paradoxically, something that is ultimately not conducive to their safety at all.

Accordingly, a theory of representative government must see the problem of its limitation not so much in the perspective of the protection of civil rights, the question on which liberal thought traditionally focuses, as of group interests, given that the security of individuals ultimately depends on balancing them. The aim of that theory should be to determine ways of institutionally balancing the various group interests making up contemporary society, with the obvious assumption that none of them is dominant enough to fully subordinate government institutions to itself. The Federalist No. 10 may be regarded as an unequalled model of an analysis of that type, dealing with the subject of factions; the new theory must, however, take into consideration the frequent changes of the structure of interests and regard it as a normal condition, and its stability as a special case. For this reason, it should regard not Pareto's optimum, but suboptimum as the ideal of the political order, assuming the possibility of achieving a new balance of interests. For the proponents of the democratisation of democracy, this

560 Cf. Jane Mansbridge, 'Using power/fighting power: The polity', in: Democracy and Difference. Contesting the Boundaries of the Political, ed. Seyla Benhabib (Princeton, NJ: Princeton University Press, 1996), p. 46 ff. 
problem is practically reduced to searching for alternative ways to articulate the interests of groups discriminated against.

The paradox of the common good refers, though it is not immediately obvious, to the extent of the freedom the citizens should allow their representatives in acting on their behalf. It ultimately depends on whether they regard the common good as something they determine through deliberation, or, conversely, only by negotiating their particular interests. If the common good is something more than the sum of these interests, the elected politicians cannot present and defend them exclusively in the forum of the decision-making body. They must have the freedom to occasionally even act against the direct, short-term interests of the represented. This is not, however, the case when the common good is reduced to an 'aggregate' of individual interests. Having the consent of the represented to deliberation, the rulers will abuse it, and excuse themselves with the supraindividual common good so as to conceal their lack of accountability to the ruled, but they will also present themselves as guardians of the voters' interests in order to explain their inability to come to a consensus with the representatives of other interests. Ultimately, it is achieved, if it is at all, as much in spite of the lack of consent of the represented, and occasionally even against their express protests, as by their consent.

Accepting only one concept of the common good gives representatives either too much or too little freedom in the representative body; consequently a theory of representative government must accept them both. Given the democratic character of that government, what will need justifying will be, obviously, the representative's acting against the particular interests of his voters if it is in the interest of the state as a whole, i.e. indirectly also in their own interest as citizens. Actions of this kind may not be justified by the citizens' will itself, as it is against them; what remains is therefore invoking the special competences of the government, which better understands the interest of the ruled. And these competences, contrary to what Hobbes says, may not be explained by its authority alone, as it follows from the very nature of representative government that if it 'knows better', it is only because the citizens have elected individuals better prepared than themselves as their representatives. Democratic reformers of democracy deny representative government any superiority over the ruled, however, and consider civic participation in the procedure to be much more important than the question of whether the decisions taken will actually benefit the entire political community.

The paradox of social diversity, the last one discussed in this book, makes us realise that in each state in which there is a civil society, government institutions are not the only representative institutions, even if they are the most important 
ones. The citizens' interests and preferences are also represented by non-elective civil society organisations, whose opinions the government must at least take into consideration. Their impact on political decisions is complex, but often more strongly felt by the citizens themselves than the impact of actions taken by elected politicians. Crucially, the sensitivity of those organisations to social needs is not limited to the time preceding an election, as their work does not oscillate to the rhythm of the election calendar. Thanks to civil society institutions, the citizens involved gain extra opportunities for representation, which, however, undermines the principle of political equality, fundamental to democracy ${ }^{561}$. Accordingly, these institutions infringe upon the representativeness of the entire political system; the interests of passive citizens, even if they make up a considerable majority, ultimately have lesser importance in decision-making by representative bodies.

A theory of representative government must take account of this double effect of civil society, which may both strengthen the ethos of democratic society and weaken the institutions of a democratic state ${ }^{562}$. That is why, avoiding both its white and black legend, it should demarcate a field of co-operation of government and non-governmental bodies and lay down the principles binding in it in a way analogous to the one in which the concept of public-private partnership defines participation of non-governmental organisations (and private enterprises) in the implementation of government policies. Political science classifies this kind of impact as lobbying, a recognised, or at least tolerated practice in most democracies; the normative theory of politics regards it as a pathology, however, and has no indulgence for it at all. The same theory praises civil engagement in nongovernmental organisations, overlooking the fact that these are two sides of the

561 And this naturally undermines also the principle of unity of sovereign power ruling a diversified society, even if it is transferred to a representative body by means of representation. Rosanvallon writes: 'How can the gap between the abstract unity of a sovereign defined by terms such as "people" and "nation" and the actual diversity of social conditions be bridged?... The whole problem of democratic representation lies in the gap between a political principle - the affirmation of the supremacy of the general will - and a sociological reality. In democracy, the people are an imperious but elusive master'; Rosanvallon, Counter-Democracy, p. 291-292.

562 A number of empirical studies, beginning with a work by Robert Putnam and his associates Making Democracy Work. Civic Traditions in Civic Italy (Princeton: Princeton University Press, 1993), argue that the relation between them is actually much more complex. 
same phenomenon, differing only by scale and the means used ${ }^{563}$. It is not an accident that this ambivalence finds its expression in theories of democratisation of democracy; unless civil society is subject to democratic control, control over it may be taken by present-day oligarchs.

A normative theory of representative government, formulating ideals, which indeed may serve as a yardstick for assessing the existing institutions, should take account of the above-mentioned issues and treat them more seriously than the present-day theories correcting the shortcomings of representation. For these are not only problems of political thought formulated in previous centuries; one can hear about each of them every single day in statements made by politicians and so-called ordinary citizens. They mostly concern specific issues, such as the question of raising retirement age, in which, in the context of the common good, the arguments of future old-age pensioners and the arguments of the state treasury clash. This list is by no means closed, naturally. Political scientists could on their part add to it new problems, which for obvious reasons could not have been included by the authors of the works discussed, beginning with the media, public opinion polls, or the role of experts. If therefore the present work might be considered a contribution to a theory of that kind, it is only to the limited extent allowed by the sources used in it.

One must also bear in mind that a theory of that kind should have clear limits. It cannot be a general theory of democracy, but only a partial one. The problem of a fair distribution of goods, fundamental rights and duties of citizens, subsidiarity of the state, division of government competences between the central and local levels, relations between the political sphere and other spheres of social life, to mention only the most obvious ones, needs a separate conceptualisation. While each of the above-mentioned questions is associated with government, its representative character is of secondary importance in this context; it only

563 For example, Sigrid Roßteutscher, critically commenting on the claims of advocates of associative democracy, points out that examinations of the results of actions taken by associations bring very ambiguous results. In any case, they cannot be said to absolutely trigger citizens' activity, because those that are highly institutionalised are conducive to their passivity; cf. Sigrid Roßteutscher, 'Associative Democracy - Fashionable Slogan or Constructive Innovation?' in: Democratic Innovation. Deliberation, Representation and Association, ed. Michael Saward (London - New York: Routledge, 2000), p. 174-178. 
matters when relations between the rulers and the ruled are concerned. The awareness of the paradoxes of the idea of representation should ultimately promote understanding of what may be reasonably expected from representative government, and what must be considered demagogy, leading only to cynicism of the former and frustration on the part of the latter. 



\section{Bibliography}

Abramowski, Edward. Filozofia społeczna. Wybór pism. Warszawa: Państwowe Wydawnictwo Naukowe, 1965.

Agamben, Giorgio. Homo Sacer: Sovereign Power and Bare Life. Trans. Daniel Heller-Roazen. California: Stanford University Press, 1998.

Alighieri, Dante. Monarchy. Trans. Prue Shaw. Cambridge-New YorkMelbourne: Cambridge University Press, 1996.

Aquinas, St. Thomas. 'The Treatise "De regimine principum” or “De regno." In: Political Writings, ed. Robert W. Dyson. Cambridge: Cambridge University Press, 2002, pp. 5-52.

Aristotle. 'Politics.' In: The Complete Works of Aristotle, the Revised Oxford Translation, ed. Jonathan Barnes. New Jersey: Princeton University Press, 1991, pp. 1009-1091.

Armour, Peter. 'Dante and Popular Sovereignty'. In: Dante and Governance, ed. John Woodhouse. Oxford: Clarendon Press, 1997, pp. 1-11.

Aron, Raymond. Main Currents in Sociological Thought. Harmondsworth: Penguin Books, 1986.

Ashcraft, Richard. 'Locke's Political Philosophy'. In: The Cambridge Companion to Locke, ed. Vere Chappell. Cambridge: Cambridge University Press, 1994.

Bentham, Jeremy. A Fragment on Government. Cambridge: Cambridge University Press, 1992.

Berlin, Isaiah. Against the Current: Essays in the History of Ideas. New York: The Viking Press, 1980.

Biezen van, Ingrid, and Michael Saward. 'Democratic Theorists and Party Scholars: Why They Don't Talk to Each Other, and Why They Should'. Perspectives on Politics, Vol. 6, No. 1, March 2008, pp. 21-35.

Bodin, Jean. Six Books of the Commonwealth. Trans. Marian J. Tooley. Oxford: Basil Blackwell, 1967.

Brito Vieira, Mónica, ed. Reclaiming Representation. Contemporary Advances in the Theory of Political Representation. New York-London: Routledge, 2017.

Broadbent, John E. 'The Importance of Class in the Political Theory of John Stuart Mill.' Canadian Journal of Political Science, Vol. 1, No. 3, 1968, pp. 270-287.

Burke, Edmund. 'A Letter to the Sheriffs of Bristol'. In: Edmund Burke on Government, Politics and Society, ed. Brian W. Hill. New York: International Publications Service, 1976, pp. 188-205. 
Burke, Edmund. 'A Representation to His Majesty' In: Edmund Burke on Government, Politics and Society, ed. Brian W. Hill. New York: International Publications Service, 1976, pp. 248-262.

Burke, Edmund. 'On American Taxation.' In: Edmund Burke on Government, Politics and Society, ed. Brian W. Hill. New York: International Publications Service, 1976, pp. 120-155.

Burke, Edmund. 'A Speech on Religious Opinions.' In: The Political Philosophy of Edmund Burke, ed. Iain Hampsher-Monk. London-New York: Longman, 1987, pp. 260-268.

Burke, Edmund. 'Speech on Conciliation with America.' In: The Political Philosophy of Edmund Burke, ed. Iain Hampsher-Monk. London-New York: Longman, 1987, pp. 111-129.

Burke, Edmund. 'Speech on Economical Reform.' In: The Political Philosophy of Edmund Burke, ed. Iain Hampsher-Monk. London-New York: Longman, 1987, pp. 129-144.

Burke, Edmund. 'Speech to the Electors of Bristol on Being Elected (Nov. 1774).' In: The Political Philosophy of Edmund Burke, ed. Iain Hampsher-Monk. London-New York: Longman, 1987, pp. 108-111.

Burke, Edmund. 'Tracts on the Laws against Popery in Ireland.' In: The Political Philosophy of Edmund Burke, ed. Iain Hampsher-Monk. London-New York: Longman, 1987, pp. 69-78.

Burke, Edmund. 'Thoughts on the Cause of the Present Discontents.' In: PreRevolutionary Writings. Cambridge: Cambridge University Press, 1993, pp. 103-192.

Burke, Edmund. 'Reflections on the Revolution in France.' In: Revolutionary Writings, ed. Iain Hampsher-Monk. Cambridge: Cambridge University Press, 2014, pp. 1-250.

Burnheim, John. Is Democracy Possible? Cambridge: Polity Press, 1985.

Canovan, Margaret. The People. Cambridge: Polity Press, 2005.

Chapman, Gerald W. Edmund Burke. His Practical Imagination. Massachusetts: Harvard University Press, 1967.

Cole, George D. H. 'Democracy Face to Face with Hugeness.' In: Essays in Social Theory. London: MacMillan \& Co. Ltd, 1950, pp. 90-96.

Cole, George D. H. 'Rousseau's Political Theory' In: Essays in Social Theory. London: MacMillan \& Co. Ltd, 1950, pp. 113-131.

Cole, George D. H. 'The Essentials of Democracy'. In: Essays in Social Theory. London: MacMillan \& Co. Ltd, 1950, pp. 97-112. 
Cole, George D. H. 'The Social Theory' In: The Pluralist Theory of the State. Selected Writings of G. D. H. Cole, J. N. Figgis, and H. J. Laski, ed. Paul Q. Hirst. London-New York: Routledge, 1989, pp. 51-111.

Conniff, James. 'Burke, Bristol, and the Concept of Representation.' The Western Political Quarterly, Vol. 30, No. 3, 1977, pp. 329-341.

Conniff, James. 'Burke and India. The Failure of the Theory of Trusteeship.' Political Research Quarterly, Vol. 46, No. 2, 1993, pp. 291-309.

Crick, Bernard. In Defence of Politics. London-Reading and Fakenham: Penguin Books, a Revised Pelican Edition, 1964.

Cullen, Daniel E. Freedom in Rousseau's Political Philosophy. DeKalb: Northern Illinois University Press, 1993.

Dahl, Robert A. Democracy and Its Critics. New Haven: Yale University Press, 1989.

Dangford, John W. 'The Problem of Language in Hobbes's Political Science.' The Journal of Politics, Vol. 42, No. 1, 1980, pp. 102-134.

Davis, Charles T. Dante and the Idea of Rome. Oxford: Clarendon Press, 1957.

D’Entrčves, Passerin A. Dante as a Political Thinker. Oxford: Clarendon Press, 1952.

Diamond, Martin. 'The Federalist.' In: History of Political Philosophy, ed. Leo Strauss and Joseph Cropsey. Chicago: The University of Chicago Press, 1987, pp. 659-679.

Disch, Lisa. "The "Constructivist Turn" in Democratic Representation: A Normative Dead-End?' Constellations, Vol. 22, No. 4, 2015, pp. 487-499.

Dovi, Suzanne. The Good Representative. New York: Wiley-Blackwell Publishing, 2007.

Dreyer, Frederick A. Burke's Politics. A Study in Whig Orthodoxy. Ontario: Wilfrid Laurier University Press, 1979.

Dryzek, John S. and Simon Niemeyer. 'Discursive Representation.' American Political Science Review, Vol. 102, 2008.

Dumouchel, Paul. " "Persona”: Reason and Representation in Hobbes's Political Philosophy.' SubStance, Vol. 25, No. 2(80), 1996, pp. 68-80.

Duncan, Graeme C. Marx and Mill: Two Views of Social Conflict and Social Harmony. Cambridge-London- New York-Melbourne: Cambridge University Press, 1973.

Dunn, John. Political Obligation in Its Historical Context. Cambridge: Cambridge University Press, 1980. 
Dunning, William A. 'Jean Bodin on Sovereignty. With Some Reference to the Doctrine of Thomas Hobbes.' Political Science Quaterly, Vol. 11, No. 1, 1896, pp. 82-104.

Eulau, Heinz. 'Changing Views of Representation.' In: Contemporary Political Science: Towards Empirical Theory, ed. Ithiel de Sola Pool. New York: McGraw Hill, 1967.

Figgis, John N. 'The Great Leviathan.' In: The Pluralist Theory of the State. Selected Writings of G. D. H. Cole, J. N. Figgis, and H. J. Laski, ed. Paul Q. Hirst. London-New York: Routledge, 1989, pp. 115-130.

Foucault, Michel. Society Must Be Defended, Lectures at the College de France, 1975-76. Trans. David Macey, eds. Mauro Bertani, Alessandro Fontana, François Ewald and Arnold Davidson. New York: Picador, 2003.

Fralin, Richard. Rousseau and Representation. A Study of the Development of His Concept of Political Institutions. New York: Columbia University Press, 1978.

Fuller, Timothy. 'Jeremy Bentham and James Mill'. In: History of Political Philosophy, ed. Leo Strauss and Joseph Cropsey. Chicago: The University of Chicago Press, 1987, pp. 710-731.

Furet, François. Interpreting the French Revolution. Trans. Elborg Forster. Cambridge: Cambridge University Press, 1997.

Gallie, Walter B. 'Essentially Contested Concepts.' Proceedings of the Aristotelian Society, New Series, Vol. LVI, 1955-56, pp. 167-198.

Gannett, Robert T. Jr. 'Bowling Ninepins in Tocqueville’s Townships.' American Political Science Review, Vol. 97, 2003, pp. 1-16.

Gładziuk, Nina. Druga Babel. Antynomie siedemnastowiecznej angielskiej myśli politycznej. Warszawa: Instytut Studiów Politycznych PAN, 2005.

Goldwin, Robert A. 'John Locke.' In: History of Political Philosophy, ed. Leo Strauss and Joseph Cropsey. Chicago: The University of Chicago Press, 1987, pp. 476-512.

Grant, Ruth W., and Robert O. Keohane. 'Accountability and Abuses of Power in World Politics.' The American Political Science Review, Vol. 99, No. 1, Feb. 2005, pp. 29-43.

Gray, John. 'On the Contestability of Social and Political Concepts.' Political Theory, Vol. 5, No. 3, Aug.1997, pp. 331-349.

Grzybowski, Jacek. Miecz i pastorat. Filozoficzny uniwersalizm sporu o charakter władzy. Tomasz z Akwinu i Dante Alighieri. Kęty: Wydawnictwo Antyk, 2006.

Hamilton, Alexander, James Madison and John Jay. The Federalist with Letters of "Brutus." ed. Terence Ball. Cambridge: Cambridge University Press, 2003. 
Hardin, Russell. 'Representing Ignorance.' Social Philosophy and Policy, Vol. 21, 2004, pp. 76-99.

Hart, Herbert L. A. Essays on Bentham. Oxford: Clarendon Press, 1982.

Hirst, Paul Q., ed. The Pluralist Theory of the State. Selected Writings of G. D. H. Cole, J. N. Figgis, and H. J. Laski. London-New York: Routledge, 1989.

Hirst, Paul Q. Associative Democracy. New Forms of Economic and Social Governance. Cambridge: Polity Press, 1994.

Hobbes, Thomas. De Cive, English Version, ed. Howard Warrender. New York: Oxford University Press, 1987.

Hobbes, Thomas. Leviathan, or the Matter, Form and Power of a Common-wealth Ecclesiastical and Civil. Cambridge: Cambridge University Press, 2003.

Kahan, Alan S. Aristocratic Liberalism. The Social and Political Thought of Jacob Burckhart, John Stuart Mill, and Alexis de Tocqueville. New York-Oxford: Oxford University Press, 1992.

Kantorowicz, Ernst H. The King's Two Bodies. A Study in Mediaeval Political Theology. New Jersey: Princeton University Press, 1997.

Kendall, Willmoore. 'How to Read Rousseau's "Government of Poland." 'In: The Government of Poland, ed. Jean-Jacques Rousseau. Indianapolis: Hacket Publishing Company, 1985.

Kierkegaard, Srrren. 'The Immediate Erotic Stages.' In: Either/Or, Part I. Trans. Howard V. Hong and Edna H. Hong. New Jersey: Princeton University Press, 1987.

King, Preston. The Ideology of Order. A Comparative Analysis of Jean Bodin and Thomas Hobbes. London: George Allen \& Unwin Ltd, 1974.

Kolb, Frank. Herrscherideologie in der Spätantike. Berlin: Akademie Verlag, 2001. Kowalska, Małgorzata. 'Demokracja przeciw arystokracji.' Przeglad Polityczny, Vol. 72, 2005, pp. 92-101.

Kraynak, Robert P. 'Tocqueville's Constitutionalism.' The American Political Science Review, Vol. 81, 1987, pp. 1175-1195.

Krouse, Richard W. 'Two Concepts of Democratic Representation: James and John Stuart Mill.' The Journal of Politics, Vol. 44, No. 2, 1982, pp. 509-537.

Kumar, Krishan. 'Civil Society: An Inquiry into the Usefulness of an Historical Term.' The British Journal of Sociology, Vol. 44, 1993, pp. 375-395.

Kymlicka, Will. Contemporary Political Philosophy. New York: Oxford University Press, 2002.

Laski, Harold J. 'The Pluralist State.' In: The Pluralist Theory of the State. Selected Writings of G. D. H. Cole, J. N. Figgis, and H. J. Laski, ed. Paul Q. Hirst. London-New York: Routledge, 1989, pp. 185-196. 
Laski, Harold J. 'The Problem of Administrative Areas.' In: The Pluralist Theory of the State. Selected Writings of G. D. H. Cole, J. N. Figgis, and H. J. Laski, ed. Paul Q. Hirst. London-New York: Routledge, 1989, pp. 133-164.

Laslett, Peter. 'Introduction. In: Two Treatises of Government, ed. John Locke. Cambridge-New York-New Rochelle-Melbourne-Sydney: Cambridge University Press, 1988, pp. 3-122.

Lewis, John U 'Jean Bodin’s “Logic of Sovereignty.” ' Political Studies, Vol. 16, 1968, pp. 206-222.

Locke, John. 'The Second Treatise of Government.' In: Two Treatises of Government, ed. John Locke. Cambridge-New York-New RochelleMelbourne-Sydney: Cambridge University Press, 1988, pp. 265-428.

Lowenthal, David. 'Montesquieu.' In: History of Political Philosophy, ed. Leo Strauss and Joseph Cropsey. Chicago: The University of Chicago Press, 1987, pp. 513-534.

Macpherson, Crawford B. The Life and Times of Liberal Democracy. OxfordNew York: Oxford University Press, 1977.

Macpherson, Crawford B. Burke. Oxford-Toronto-Melbourne: Oxford University Press, 1980.

Malcom, Noel. 'The Name and Nature of Leviathan: Political Symbolism and Biblical Exegesis.' Intellectual History Review, Vol. 17, No. 1, 2007, pp. 29-58.

Manent, Pierre. An Intellectual History of Liberalism. Trans. Rebecca Balinski and Jerrold E. Seigel. Princeton: Princeton University Press, 1996.

Manin, Bernard. The Principles of Representative Government. Cambridge: Cambridge University Press, 1997.

Mansbridge, Jane. 'Using Power/Fighting Power: The Polity'. In: Democracy and Difference. Contesting the Boundaries of the Political, ed. Seyla Benhabib. New Jersey: Princeton University Press, 1996, pp. 46-66.

Mansbridge, Jane. 'Rethinking Representation.' American Political Science Review, Vol. 97, 2003, pp. 515-528.

Mansbridge, Jane. 'Clarifying the Concept of Representation.' American Political Science Review, Vol. 3, 2011, pp. 621-630.

Mansfield, Harvey C. 'Modern and Medieval Representation.' In: Nomos X: Representation, ed. James R. Pennock and John W. Chapman. New York: Artherton, 1968, pp. 55-82.

Mansfield, Harvey C. 'Edmund Burke.' In: History of Political Philosophy, ed. Leo Strauss and Joseph Cropsey. Chicago: The University of Chicago Press, 1987, pp. 687-709. 
Marsilius of Padua. The Defender of the Peace. Trans. Annabel Brett. New York: Cambridge University Press, 2005.

Matyszkowicz, Mateusz. 'Komentarz.' In: O królowaniu - królowi Cypru. Trans. Mateusz Matyszkowicz, ed. Tomasz z Akwinu. Kraków: Ośrodek Myśli Politycznej, Wyższa Szkoła Europejska im. Józefa Tischnera, 2006, pp. 133-299.

Merta, Tomasz. 'Roztropność Edmunda Burke’a.' In: Nieodzowność konserwatyzmu. Pisma wybrane. Warszawa: Teologia Polityczna, Muzeum Historii Polski, 2011, pp. 73-84.

Mill, James. 'Essay on Government.' In: Political Writings. Cambridge: Cambridge University Press, 1992, pp. 1-42.

Mill, John S. 'On Liberty' In: On Liberty and Other Writings. Cambridge: Cambridge University Press, 1989, pp. 1-116.

Mill, John S. Considerations on Representative Government. Cambridge: Cambridge University Press, 2010.

Montesquieu, Charles Louis de Secondat. The Spirit of the Laws. Trans. Anne M. Cohler, Basia S. Miller and Harold S. Stone. Cambridge-New York-New Rochelle-Melbourne-Sydney: Cambridge University Press, 2002.

Morales, Maria H. Perfect Equality. John Stuart Mill on Well-Constituted Communities. Lanham-Boulder-New York-London: Rowman \& Littlefield Publishers, 1996.

Näsström, Sofia. 'Representative Democracy is Classless.' In: Reclaiming Representation. Contemporary Advances in the Theory of Political Representation, ed. Mónica Brito Vieira. New York-London: Routledge, 2017, pp. 167-183.

Nederman, Cary J. 'Knowledge, Consent and the Critique of Political Representation in Marsiglio of Padua's Defensor Pacis.' Political Studies, Vol. 1, No. 39, 1991, pp. 19-35.

Nozick, Robert. Anarchy, State, Utopia. Oxford-Cambridge: Blackwell, 1999.

O'Gorman, Frank. Edmund Burke. His Political Philosophy. BloomingtonLondon: Indiana University Press, 1973.

Oakeshott, Michael. On Human Conduct. Oxford: Clarendon Press/Oxford University Press, 2003.

Ogonowski, Zbigniew. Locke. Warszawa: Książka i Wiedza, 1972.

Pangle, Thomas L. Montesquieu's Philosophy of Liberalism. A Commentary on "The Spirit of the Laws." Chicago-London: University of Chicago Press, 1973. Pateman, Carole. The Problem of Political Obligation. Cambridge: Polity Press, 1979. 
Pieliński, Krzysztof. Konserwatyzm jako oswajanie chaosu świata empirycznego (przypadek Edmunda Burke’a). Warszawa: Elipsa, 1993.

Pitkin, Hanna. The Concept of Representation. Berkley-Los Angeles-London: University of California Press 1967.

Plamenatz, John P. Man and Society. Political and Social Theories from Machiavelli to Marx (a revised edition). London-New York: Longman, 1992.

Plotke, David. 'Representation is Democracy.' Constellations, Vol. 4, 1997, pp. 19-34.

Plotke, David. 'Representation is Democracy.' Constellations, Vol. 4, 1997, pp. 723-736.

Pocock, John G. A. 'Burke and the Ancient Constitution - A Problem in the History of Ideas.' The Historical Journal, Vol. 2, 1960, pp. 125-143.

Przeworski, Adam. 'Deliberation and Ideological Domination.' In: Deliberative Democracy, ed. Jon Elster. Cambridge: Cambridge University Press, 1998, pp. 140-161.

Rahe, Paul. Montesquieu and the Logic of Liberty. New Haven-London: Yale University Press, 2009.

Rau, Zbigniew. 'Wstęp. In: Dwa traktaty o rządzie. Trans. Zbigniew Rau, ed. John Locke. Warszawa: Wydawnictwo Naukowe PWN, 1992, pp. V-CXI.

Rehfeld, Andrew. The Concept of Constituency: Political Representation, Democratic Legitimacy and Institutional Design. Cambridge: Cambridge University Press, 2005.

Rehfeld, Andrew. 'Towards a General Theory of Political Representation.' The Journal of Politics, Vol. 68, 2006, pp. 1-21.

Rehfeld, Andrew. 'Representation Rethought: On Trustees, Delegates, and Gyroscopes in the Study of Political Representation and Democracy'. American Political Science Review, Vol. 2, 2009, pp. 54-559.

Rehfeld, Andrew. 'The Concepts of Representation.' American Political Science Review, Vol. 3, 2011, pp. 621-630.

Rehfeld, Andrew. 'What is Representation?' In: Reclaiming Representation. Contemporary Advances in the Theory of Political Representation, ed. Mónica Brito Vieira. New York-London: Routledge, 2017, pp. 50-74.

Richter, Melvin. 'Comparative Political Analysis in Montesquieu and Tocqueville.' Comparative Politics, Vol. 1, 1969, pp. 129-160.

Rosanvallon, Pierre. Counter-Democracy: Politics in an Age of Distrust. Trans. Arthur Goldhammer. Cambridge: Cambridge University Press, 2008.

Rosen, Frederick. Jeremy Bentham and Representative Democracy. A Study of the Constitutional Code. Oxford: Clarendon Press, 1983. 
Roßteutscher, Sigrid. 'Associative Democracy - Fashionable Slogan or Constructive Innovation?' In: Democratic Innovation. Deliberation, Representation and Association, ed. Michael Saward. London-New York: Routledge, 2000, pp. 172-183.

Rousseau, Jean-Jacques. 'Letter to M. d'Alamert on the Theatre.' In: Politics and the Arts. Trans. Allan Bloom. New York: Cornell University Press, 1968, pp. $3-138$.

Rousseau, Jean-Jacques. 'Considerations on the Government of Poland.' In: The Social Contract and Other Later Political Writings, ed. Victor Gourevitch. Cambridge: Cambridge University Press, 1997, pp. 177-260.

Rousseau, Jean-Jacques. 'Discourse on Political Economy' In: The Social Contract and Other Later Political Writings, ed. Victor Gourevitch. Cambridge: Cambridge University Press, 1997, pp. 3-38.

Rousseau, Jean-Jacques. 'Of the Social Contract.' In: The Social Contract and Other Later Political Writings, ed. Victor Gourevitch. Cambridge: Cambridge University Press, 1997, pp. 39-152.

Runciman, David. 'The Paradox of Political Representation.' Journal of Political Philosophy, Vol. 15, 2007, pp. 93-114.

Runciman, David, and Mónica B. Vieira. Representation. Cambridge: Polity Press, 2008.

Rydz, Romuald. Edmund Burke na ścieżkach wolności. Poznań: Wydawnictwo Poznańskie, 2005.

Sabine, George H. A History of Political Theory. Illinois: Dryden Press, 1973.

Sabl, Andrew. Ruling Passions: Political Offices and Democratic Ethics. New Jersey: Princeton University Press, 2002.

Sabl, Andrew. 'The Two Cultures of Democratic Theory: Responsiveness, Democratic Quality, and the Empirical-Normative Divide.' In: Reclaiming Representation. Contemporary Advances in the Theory of Political Representation, ed. Mónica Brito Vieira. New York-London: Routledge, 2017, pp. 97-131.

Saward, Michael. 'The Representative Claim.' Contemporary Political Theory, Vol. 5, 2006, pp. 297-318.

Schelsky, Helmut. Thomas Hobbes. Eine politische Lehre. Berlin: Dunker \& Humblot, 1981.

Schmitt, Carl. Political Theology: Four Chapters on the Concept of Sovereignty. Trans. George Schwab. Chicago: The University of Chicago Press, 2005.

Schmitt, Carl. Lewiatan w teorii państwa prawa Hobbesa. Trans. Mateusz Falkowski. Warszawa: Prószyński i S-ka, 2008. 
Schumpeter, Joseph. Capitalism, Socialism and Democracy. London-New York: Routledge, 2003.

Schwartz, Nancy L. The Blue Guitar. Political Representation and Community. Chicago: The University of Chicago Press, 1988.

Shapiro, Ian. The State of Democratic Theory. New Jersey: Princeton University Press, 2003.

Shklar, Judith N. Political Thought and Political Thinkers. Chicago-London: University of Chicago Press, 1998.

Sigmund, Peter E. Jr. 'The Influence of Marsilius of Padua on 15th-Century Conciliarism.' Journal of the History of Ideas, Vol. 23, No. 3, 1962, pp. 392-402.

Simon, Yves R. A General Theory of Authority. Indiana: University of Notre Dame Press, 1980.

Skinner, Quentin. The Foundations of Modern Political Thought. Cambridge: Cambridge University Press, 1978.

Smith, Jeffrey A. 'Nationalism, Virtue, and the Spirit of Liberty in Rousseau's Government of Poland.' The Review of Politics, Vol. 65, No. 3, 2003, pp. 409-437.

Spafford, Duff. 'Mill's Majority Principle.' Canadian Journal of Political Science, Vol. 18, No. 3, 1985, pp. 599-608.

tevens, Jacqueline. 'The Reasonableness of John Locke's Majority.' Political Theory, Vol. 24, No. 3, 1996, pp. 423-463.

Stimson, Shannon and Murray Milgate. 'Utility, Property, and Political Participation: James Mill on Democratic Reform.' American Political Science Review, Vol. 87, 1993, pp. 901-911.

Strauss, Leo. Natural Right and History. A Cogent Examination of One of the Most Significant Issues in Modern Political and Social History. Chicago-London: The University of Chicago Press, 1965.

Strauss, Leo. 'Marsilius of Padua.' In: History of Political Philosophy, ed. Leo Strauss and James Cropsey. Chicago-London: The University of Chicago Press, 1987, pp. 276-295.

Strauss, Leo. The Political Philosophy of Hobbes: Its Basis and Its Genesis. Chicago: University of Chicago Press, 1996.

Śpiewak, Paweł. W stronę dobra wspólnego. Warszawa: Wydawnictwo Aletheia, 2005.

Tamás, Gáspar M. 'A Disquisition on Civil Society'. Social Research, Vol. 61, No. 2, 1994, pp. 205-222.

Tobiasz, Marcin. Etatyści czy pluraliści? Dylematy brytyjskiej lewicy w pierwszej połowie XX wieku. Warszawa: Dom Wydawniczy Elipsa, 2010. 
Tocqueville, Alexis de. Democracy in America. Chicago-London: The University of Chicago Press, 2002.

Tulejski, Tomasz. Od zasady użyteczności do demokracji. Filozofia polityczna Jeremy Benthama. Łódź: Wydawnictwa Uniwersytetu Łódzkiego, 2004.

Tuly, James. An Approach to Political Philosophy: Locke in Contexts. Cambridge: Cambridge University Press, 1993.

Urbinati, Nadia. 'Representation as Advocacy: A Study of Democratic Deliberation.' Political Theory, Vol. 28, No. 6, Dec. 2000, pp. 758-786.

Urbinati, Nadia, and Mark E. Warren. 'The Concept of Representation in Contemporary Political Theory.' Annual Review of Political Science, Vol. 2, 2008, pp. 387-412.

Villa, Dana. 'Tocqueville and Civil Society.' In: The Cambridge Companion to Tocqueville, ed. Cheryl B. Welch. Cambridge: Cambridge University Press, 2007, pp. 216-244.

Villa, Dana. Public Freedom. New Jersey-Oxford: Princeton University Press, 2008.

Voegelin, Eric. The People of God. Materialien zu Eric Voegelins 'History of Ideas'. München: Ludwig-Maximilian-Universität, 1941.

Voegelin, Eric. The Collected Works of Eric Voegelin, XXII, History of Political Ideas, IV, Renaissance and Reformation. Columbia-London: University of Missouri Press, 1989.

Walzer, Michael. 'The Civil Society Argument.' In: Dimensions of Radical Democracy. Pluralism, Citizenship, Community, ed. Chantal Mouffe. London: Verso, 1992, pp. 89-107.

Warren, Mark E., and Dario Castiglione. 'The Transformation of Democratic Representation.' Democracy and Society, Vol. 2, No. 1, 2004, pp. 5-22.

Waśkiewicz, Andrzej. 'John Locke i problem integracji europejskiej'. In: Dawne idee, nowe problemy, ed. Paweł Śpiewak. Warszawa: Wydawnictwa Uniwersytetu Warszawskiego, 2010, pp. 13-32.

Waśkiewicz, Andrzej. 'Representation as Social Relation.' Polish Sociological Review, Vol. 3, 2010, pp. 305-317.

Waśkiewicz, Andrzej. Strangers by Choice. An Asocial Philosophy of Life. Trans. Tulsi Bhambry and Agnieszka Waśkiewicz. Frankfurt am Mein: Peter Lang Edition, 2015.

Wolin, Sheldon. Politics and Vision. Continuity and Innovation in Western Political Thought. London: G. Alin \& Unwin, 1961.

Wolin, Sheldon. 'Hobbes and the Culture of Despotism.' In: Thomas Hobbes and Political Theory, ed. Mary G. Dietz. Kansas: University Press of Kansas, 1990, pp. 9-36. 
Woodhouse, John. 'Dante and Governance: Contexts and Contents.' In: Dante and Governance. Oxford: Clarendon Press, 1997, pp. 1-11.

Wójtowicz, Andrzej. Model władzy państwowej Marsyliusza z Padwy. Katowice: Wydawnictwa Uniwersytetu Śląskiego, 1977.

Yolton, John W. 'Representative.' A Locke Dictionary. Oxford: Blackwell, 1993, pp. $227-229$.

Żyro, Tomasz. Wola polityczna. Siedem prób z filozofii praktycznej. Warszawa: Wydawnictwa Akademickie i Profesjonalne, 2008. 


\section{Index}

A

Abramowski, Edward 196, 206, 255

Agamben, Giorgio 77, 95, 98, 255

Alighieri, Dante 19, 24, 29, 32, 36, 38-40, 255

Aquinas, St. Thomas 19, 24, 29, 31, $33,34,68,255$

Aristotle 16, 19, 23-27, 29, 31-33, $35,36,48,49,51-53,55,55-57$, $60,61,65,71-74,76,87,96,101$, $107,198,111,122,151,155,156$, $161,175,176,182,183,189,202$, 205, 209, 245, 255

Armour, Peter 40, 41 Aron, Raymond 108 Ashcraft, Richard 122

\section{B}

Bentham, Jeremy 180, 196-200, 202, 203, 205, 232, 255, 258, 259, 262, 265

Berlin, Isaiah 108, 255

Biezen van, Ingrid 235

Bodin, Jean 20, 65-77, 87, 90, 100, 101, 102, 104, 105, 107, 207, 255, 258-260

Brito Vieira, Mónica 10, 14, 15, 83, 103, 197, 237, 255, 261-263

Broadbent, John E. 182, 255

Burke, Edmund 20, 101, 152-164, 169, 171, 178, 189-191, 201, 230, 244, 255, 256, 257, 260-263

Burnheim, John 204, 206, 210

C

Canovan, Margaret 63, 129, 131

Chapman, Gerald W. 19, 163, 256, 260
Cole, George D. H. 20, 196, 197, 203-205, 256, 257, 259

Conniff, James 159, 160, 257

Crick, Bernard 98

Cullen, Daniel 167, 168, 257

D

Dahl, Robert A. 152, 228, 257

Dangford, John W. 80, 257

Davis, Charles T. 40, 257

D’Entrèves, Passerin A. 257

Diamond, Martin 109, 257

Disch, Lisa 242, 257

Dovi, Suzanne 16, 233, 248, 257

Dreyer, Frederick A. 156, 257

Dryzek, John S. 204, 257

Dumouchel, Paul 86, 257

Duncan, Graeme C. 154, 176, 179, 257

Dunn, John 114, 257

Dunning, William A. 101, 258

E

Eulau, Heinz 25, 158, 160, 163, 258

F

Figgis, John N. 196, 197, 206, 257-260

Foucault, Michel 99, 258

Fralin, Richard 153, 165, 169, 172, 258

Fuller, Timothy 202, 258

Furet, François 167, 215, 258

G

Gallie, Walter B. 236, 258

Gannett, Robert T. Jr. 215, 258 
Gładziuk, Nina 97, 98, 258

Goldwin, Robert A. 97, 98, 258

Grant, Ruth W. 247, 258

Gray, John 236, 258

Grzybowski, Jacek 32, 35, 258

H

Hamilton, Alexander 109, 140-144, 258

Hardin, Russell 189, 259

Hart, Herbert L. A. 199, 259

Hirst, Paul Q. 196, 197, 205, 206, 209, 210, 257-260

Hobbes, Thomas 15, 20, 57, 59, $66,67,74,76-105,107,110,112$, $113,114,117,119-122,124,125$, $127,130,133,135,136,138,141$, $145,146,151,152,156,163,166$, $195,207,225,229,238,248,250$, 257-259, 263-265

K

Kahan, Alan S. 176, 180, 259

Kantorowicz, Ernst H. 28, 34, 61,259

Kendall, Willmoore 153, 174, 259

Kierkegaard, Søren 23, 58, 259

King, Preston 67, 259

Kolb, Frank 27, 259

Kowalska, Małgorzata 227, 259

Kraynak, Robert P. 216, 227, 259

Krouse, Richard W. 176, 259

Kumar, Krishan 211, 259

Kymlicka, Will 16, 259

L

Laski, Harold J. 196, 197, 204, 205, 207, 231, 257-260

Laslett, Peter 110, 113, 114, 128,260

Lewis, John U. 260
Locke, John 11, 20, 49, 66, 86, 99, 100, 107, 109-131, 133-135, 145, $146,148,155,156,171,243,255$, 258, 260-262, 264-266

Lowenthal, David 108, 132, 260

M

Macpherson, Crawford B. 157, 163, 196, 260

Malcom, Noel 93, 94, 260

Manent, Pierre 28, 82, 83, 90, 97, $111,113,135,137-139,142,146-$ $148,157,177,178,191,214,217$, 222, 224, 226, 227, 229, 232, 260

Manin, Bernard 62, 109, 143, 144,260

Mansbridge, Jane 15, 16, 245, 249, 260

Mansfield, Harvey C. 19, 84, 97, 152,260

Marsilius of Padua 19, 24, 29, 42-47, 49-58, 60, 70, 261, 264

Matyszkowicz, Mateusz 32-35, 261

Merta, Tomasz 152, 261

Mill, James 176, 196, 198-200, 202, 257-259, 261, 264

Montesquieu, Charles Louis de Secondat 20, 87, 107-109, 127, $128,131-142,145,147,148,160$, $161,199,226,249,260-262$

Morales, Maria H. 179, 180, 261

$\mathbf{N}$

Näsström, Sofia 15, 261

Nederman, Cary J. 53, 261

Nozick, Robert 116, 261

O

O'Gorman, Frank 160, 163, 261

Oakeshott, Michael 79, 89, 116, 261 
Ogonowski, Zbigniew 117, 122, 125,261

$\mathbf{P}$

Pangle, Thomas L. 108, 135-137, 261

Pateman, Carole 113, 115, 118,261

Pieliński, Krzysztof 155, 262

Pitkin, Hanna 9, 18, 80, 81, 88, 159, 160, 230, 262

Plamenatz, John P. 68, 101, 118, $120,130,132,262$

Plotke, David 11, 262

Pocock, John G. A. 157, 262

Przeworski, Adam 188, 262

$\mathbf{R}$

Rahe, Paul 132, 133, 262

Rau, Zbigniew 111, 117, 262

Rehfeld, Andrew 15, 16, 236, 242, 246, 247, 262

Richter, Melvin 226, 262

Rosanvallon, Pierre 21, 247, 251, 262

Rosen, Frederick 196, 200, 262

Roßteutscher, Sigrid 252, 263

Rousseau, Jean-Jacques 20, 97, 131, $140,146,152-155,164-176,178$, 181, 183, 188-191, 195-198, 204, 209, 213, 227-229, 232, 239, 240, 244, 247, 256-259, 263, 264

Runciman, David 10, 18, 83, 103, 197, 237, 263

Rydz, Romuald 157, 263

$S$

Sabine, George H. 69, 70, 263

Sabl, Andrew 14, 16, 190, 263

Saward, Michael 13, 15, 18, 235, 241, 246, 252, 255, 263

Schelsky, Helmut 79, 97, 263
Schmitt, Carl 23, 61, 85, 93, 98-100, 103, 104, 248, 263

Schumpeter, Joseph 11, 238-246, 264

Schwartz, Nancy L. 9, 264

Shapiro, Ian 13, 235, 240, 264

Shklar, Judith N. 108, 109, 132, 140, 264

Sigmund, Peter E. Jr. 29, 49, 264

Simon, Yves R. 30, 264

Skinner, Quentin 54, 58, 102, 264

Smith, Jeffrey A. 170, 264

Spafford, Duff 184, 264

Stimson, Shannon 202, 203, 264

Strauss, Leo 46, 49, 52, 54, 65, 87, 92, 93, 108-111, 114, 115, 152, 155, 202, 225, 257, 258, 260, 264

Śpiewak, Paweł 118, 151, 264, 265

$\mathrm{T}$

Tamás, Gáspar M. 231, 264

Tobiasz, Marcin 196, 207, 264

Tocqueville, Alexis de 16, 20, 136, $176,177,182,185,196-198$, 209-229, 231-233, 258, 259, 262, 265

Tulejski, Tomasz 198, 200, 265

Tuly, James 114, 129, 130, 131, 265

U

Urbinati, Nadia $10,16,21,177$, 236, 265

V

Villa, Dana 217, 219, 265

Voegelin, Eric 19, 37, 63, 265

W

Walzer, Michael 228, 265

Warren, Mark E. 10, 21, 78, 259, 265 
Waśkiewicz, Andrzej 10, 18, 118, 165, 246, 265

Wolin, Sheldon 77, 87, 96, 97, 265 Woodhouse, John 39, 40, 255, 266

Wójtowicz, Andrzej 49, 52, 54, 57,266
Y

Yolton, John W. 124, 266

Z

Żyro, Tomasz 38, 50, 56, 266 


\section{Studies in Social Sciences, Philosophy and History of Ideas}

Edited by Bogusław Paź

Vol. 1 Józef Niżnik: Twentieth Century Wars in European Memory. 2013.

Vol. 2 Szymon Wróbel: Deferring the Self. 2013.

Vol. 3 Cain Elliott: Fire Backstage. Philip Rieff and the Monastery of Culture. 2013.

Vol. 4 Seweryn Blandzi: Platon und das Problem der Letztbegründung der Metaphysik. Eine historische Einführung. 2014.

Vol. 5 Maria Gołębiewska / Andrzej Leder/Paul Zawadzki (éds.): L'homme démocratique. Perspectives de recherche. 2014.

Vol. 6 Zeynep Talay-Turner: Philosophy, Literature, and the Dissolution of the Subject. Nietzsche, Musil, Atay. 2014.

Vol. 7 Saidbek Goziev: Mahalla - Traditional Institution in Tajikistan and Civil Society in the West. 2015.

Vol. 8 Andrzej Rychard / Gabriel Motzkin (eds.): The Legacy of Polish Solidarity. Social Activism, Regime Collapse, and the Building of a New Society. 2015.

Vol. 9 Wojciech Klimczyk / Agata Świerzowska (eds.): Music and Genocide. 2015.

Vol. 10 Paweł B. Sztabiński / Henryk Domański / Franciszek Sztabiński (eds.): Hopes and Anxieties in Europe. Six Waves of the European Social Survey. 2015.

Vol. 11 Gavin Rae: Privatising Capital. The Commodification of Poland's Welfare State. 2015.

Vol. 12 Adriana Mica / Jan Winczorek / Rafał Wiśniewski (eds.): Sociologies of Formality and Informality. 2015.

Vol. 13 Henryk Domański: The Polish Middle Class. Translated by Patrycja Poniatowska. 2015.

Vol. 14 Henryk Domański: Prestige. Translated by Patrycja Poniatowska. 2015.

Vol. 15 Cezary Wodziński: Heidegger and the Problem of Evil. Translated into English by Agata Bielik-Robson and Patrick Trompiz. 2016.

Vol. 16 Maria Gołębiewska (ed.): Cultural Normativity. Between Philosophical Apriority and Social Practices. 2017.

Vol. 17 Anita Williams: Psychology and Formalisation. Phenomenology, Ethnomethodology and Statistics. 2017.

Vol. 18 Mikołaj Pawlak: Tying Micro and Macro. 2018.

Vol. 19 Franciszek Sztabiński / Henryk Domański / Paweł B. Sztabiński (eds.): New Uncertainties and Anxieties in Europe. Seven Waves of the European Social Survey. 2018.

Vol. 20 Adriana Mica / Katarzyna M. Wyrzykowska / Rafał Wiśniewski / Iwona Zielińska (eds.): Sociology of the Invisible Hand. 2018.

Vol. 21 Jan Felicjan Terelak: Psychology of the Operator of Technical Devices. 2019

Vol. 22 Dorota Maria Leszczyna: Del idealismo al realismo crítico. La política como realización en José Ortega y Gasset. 2019.

Vol. 23 Zbigniew Drozdowicz: La république des savants. Sans révérence. Traduit du polonais par Catherine Popczyk. 2019

Vol. 24 Andrzej Waśkiewicz: The Idea of Political Representation and Its Paradoxes. Translated from Polish by Agnieszka Waśkiewicz and Marilyn Burton. 2020 
www.peterlang.com 